\title{
UNIVERSIDADE DO ESTADO DE SÃO PAULO
}

ESCOLA DE COMUNICAÇÃO E ARTES

\section{CAMILA COSTA ZANETTA}

Espaços para criar e conviver: processos criativos em jogos cênico-musicais na educação musical com crianças 
CAMILA COSTA ZANETTA

Espaços para criar e conviver: processos criativos em jogos cênico-musicais na educação musical com crianças

Dissertação apresentada à Escola de Comunicação e Artes da Universidade de São Paulo para obtenção do título de Mestre em Música

Área de concentração: Processos de criação musical

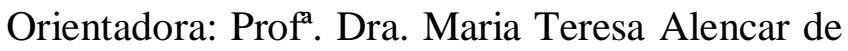
Brito

São Paulo

2014 
Nome: ZANETTA, Camila Costa.

Título: Espaços para criar e conviver: processos criativos em jogos cênico-musicais na educação musical com crianças

Dissertação apresentada à Escola de

Comunicação e Artes da Universidade de São

Paulo para obtenção do título de Mestre em Música

Aprovado em:

Banca examinadora

Prof. Dr.

Instituição:

Julgamento: Assinatura:

Prof. Dr. Instituição:

Julgamento: Assinatura:

Prof. Dr. Instituição:

Julgamento: Assinatura: 
À minha família. 


\section{AGRADECIMENTOS}

Aos meus pais, Rosana e Victor, que mesmo distantes se fizeram presentes, sempre incentivando e acreditando em meu trabalho. Muito obrigada por todo o apoio e carinho!

Ao Allan, meu companheiro, pelos momentos compartilhados. Pelo suporte que tanto precisei quando deixamos nossas casas e encaramos esta jornada de estudos na terra da garoa... Obrigada por sua compreensão e carinho. Agradeço também as leituras e contribuições feitas a este trabalho, assim como sua participação na Oficina de Música proposta, filmando e fotografando todos os encontros. Enfim, por recuperar o material desta pesquisa após um roubo!

À minha irmã Amanda e minha prima Angélica, pelas conversas, histórias e risadas compartilhadas neste período, que muito me animaram quando precisei.

À professora Teca, com quem tanto aprendi nesta trajetória. Agradeço a oportunidade ímpar de desenvolver este trabalho com a sua orientação, assim como todos os ensinamentos de música e vida.

Aos amigos Bruno Sidnei, Cleber Floriano, Diego Souza, Eloise Hack e Juliana Sens, que me ajudaram de diferentes maneiras. Agradeço o constante incentivo, a companhia (ainda que à distância) e por sempre me motivarem!

À Eva Eloa e Izaura Elfrida, pela ajuda que possibilitou, em momentos difíceis, meu estudo e posterior ingresso no curso de mestrado.

Às crianças, que deram vida a esta pesquisa! Agradeço a oportunidade de trabalharmos juntos e compartilharmos muitas histórias...

Aos pais dos alunos, por autorizarem a participação das crianças na pesquisa.

À Escola de Aplicação da Universidade de São Paulo, na pessoa da Fátima Morissawa, pela ajuda sempre que necessário.

À professora Denise, por acompanhar e participar da Oficina de Música, possibilitando a realização desta proposta no espaço da Escola de Aplicação.

Aos professores doutores Eugênio Tadeu Pereira, Fábio Cardozo de Mello Cintra, Marisa Trench de Oliveira Fonterrada e Pedro Paulo Salles, que compuseram as bancas deste trabalho. Agradeço as leituras atenciosas e as contribuições feitas a esta dissertação.

À FAPESP, pela bolsa concedida durante parte do curso. 


\section{RESUMO}

ZANETTA, Camila Costa. Espaços para criar e conviver: processos criativos em jogos cênico-musicais na educação musical com crianças. 2014. 174f. Dissertação (Mestrado) Escola de Comunicação e Artes, Universidade do Estado de São Paulo, São Paulo, 2014.

Esta pesquisa propõe reflexões acerca da importância dos espaços para a criação na educação musical. Focalizando as práticas de improvisação no ambiente do jogo, foram investigadas as contribuições das experiências de improvisação em jogos cênico-musicais para a formação integral das crianças. O pensamento pedagógico-musical de Hans-Joachim Koellreutter e os jogos desenvolvidos pelo educador nortearam este estudo, assim como as ideias desenvolvidas pela educadora Teca Alencar de Brito. Através de uma pesquisa-ação, uma Oficina de Música voltada a crianças entre sete e dez anos foi instaurada. Esta Oficina perdurou dois meses e foi realizada na Escola de Aplicação da Faculdade de Educação da Universidade de São Paulo (EAFEUSP), atendendo os alunos desta instituição. Visando a perspectiva das crianças a respeito das contribuições dos jogos de improvisação, a coleta de dados articulou diferentes procedimentos: (1) registros audiovisuais; (2) entrevistas semiestruturadas com as crianças; (3) protocolos confeccionados pelos alunos. Considerando a abordagem qualitativa da pesquisa, que possibilita mudanças no decorrer do processo, acrescentou-se às técnicas de coleta de dados uma entrevista semiestruturada com a professora de música da EAFEUSP (professora que acompanhou a prática da pesquisa-ação). $\mathrm{Na}$ análise dos dados, apontamentos gerais e específicos foram apresentados, relacionando as opiniões das crianças e da professora de música com as ideias de autores abarcados na pesquisa. Os resultados indicam que as práticas de improvisação, no contexto do jogo cênicomusical, propiciam o desenvolvimento de capacidades musicais e humanas, permitindo pensar acerca da educação musical como meio para a formação integral da criança.

Palavras-chave: Educação musical. Processos criativos. Jogos de improvisação cênicomusicais. 


\begin{abstract}
ZANETTA, Camila Costa. Spaces to create and living together: creative processes in scenic-musical games in music education with children. 2014. 174f. Dissertação (Mestrado) - Escola de Comunicação e Artes, Universidade do Estado de São Paulo, São Paulo, 2014.

The purpose of this research is to reflect about the value of spaces for creation in Music Education. Focusing the improvisation practices inside the game environment, the scenicmusical games improvisation experiences contributions to an integral formation of children were investigated. Hans-Joachim Koellreutter's pedagogic-musical thoughts and his games guided this study, as well as the ideas developed by Teca Alencar de Brito. Proposed as an action-research, was offered a Music Workshop to children from seven to ten years old from Application School at USP, occurring weekly between April and June of 2014. Aiming the children own perspective about the improvisation games contributions, the data collection techniques used were: (1) video record; (2) semi-structured interviews with the children; (3) protocols - made by the children. Considering the research qualitative approach, that permits changes in the course of the research process, a semi-structured interview with the school teacher (that accompanied the practice) was added to the data collection. General and specific appointments were presented in the data analysis, relating the opinions of the students and the music teacher with the authors ideas embraced in the research. The results indicate that the improvisation practices, in the scenic-musical game context, provide the development of both musical and human capacities, allowing to think Music Education as a way to children integral formation.
\end{abstract}

Keywords: Music Education. Creative processes. Scenic-musical improvisation games. 


\section{LISTA DE ILUSTRAÇÕES}

Figura 1 - Desenho metodológico. 87

Figura 2 - Partitura da canção Bate o monjolo.

Figura 3 - Partitura de "Bate o monjolo" com ambas as vozes: melodia cantada e acompanhamento rítmico dos copos. .98

Figura 4 - Anotações referentes ao jogo Pega-pega animal. 102

Figura 5 - Anotações referentes ao jogo Música.. 104

Figura 6 - Anotações referentes ao jogo Detetive. 105

Figura 7 - Anotações referentes ao jogo Competição de instrumentos. 107

Figura 8 - Participantes da Oficina de Música durante o jogo Floresta e seus bichos. 110

Figura 9 - Protocolo de Gabriela e Larissa. 119

Figura 10 - Protocolo de Fernanda. 123

Figura 11 - Protocolo de Pedro. 125

Figura 12 - Protocolo de Pedro referente ao jogo criado por seu grupo. 131

Figura 13 - Protocolo de Fernanda. 133

Figura 14 - Protocolo de Bernardo. 139

Figura 15 - Protocolos referentes ao jogo "Bate o Monjolo". 145

Figura 16 - Protocolos de Luana, Isabela, Pedro, Patrícia e Larissa. 146

Figura 17 - Registros feitos por João na capa do caderno. 149

Figura 18 - Registro de alguns dos instrumentos disponibilizados em sala para os jogos.... 150 Figura 19 - Um leão e um gato: dois animais cujos sons foram imitados no jogo "Floresta e seus bichos". 150

Figura 20 - Registro realizado após a apreciação do vídeo "Sound of Noise - Music for One Apartment and Six Drummers”

Figura 21 - Registros do jogo "Bate o monjolo”. À esquerda, o copo utilizado como acompanhamento rítmico e durante as improvisações. À direita, o "barco do pirata”, personagem do jogo. 


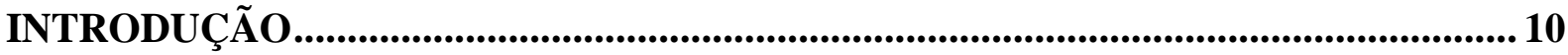

1 PROPOSIÇÕES PEDAGÓGICO-MUSICAIS E OS DESCOMPASSOS NA EDUCAÇÃO: FISSURAS EXISTENTES FRENTE ÀS NOVAS QUESTÕES.................16

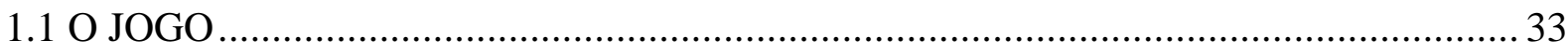

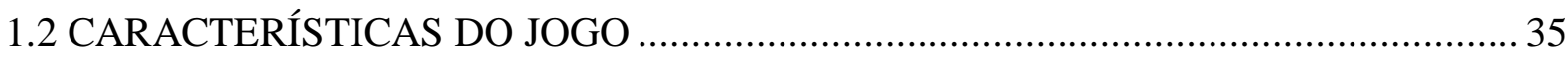

1.3 O JOGO NOS PROCESSOS DE ENSINO E APRENDIZAGEM …………………......... 37

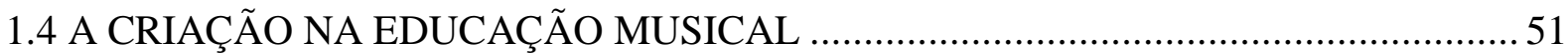

1.5 HANS-JOACHIM KOELLREUTTER ...................................................................... 54

1.5.1 Koeullretter e a educação: o pensamento pedagógico-musical do educador ........... 58

2 OFICINA DE MÚSICA: CONSIDERAÇÕES METODOLÓGICAS SOBRE A PRÁTICA DA PESQUISA-AÇÃO E O CAMPO DE ATUAÇÃO........................................68

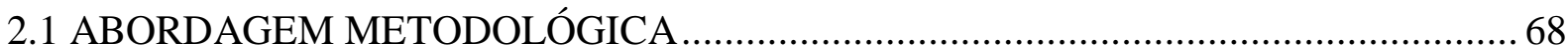

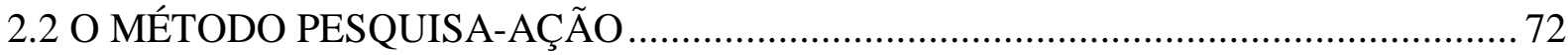

2.3 INSTRUMENTOS/MEIOS PARA A COLETA DE DADOS .......................................... 74

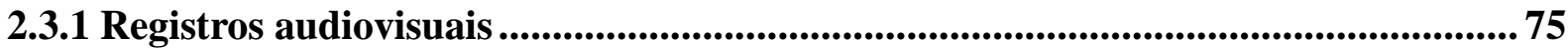

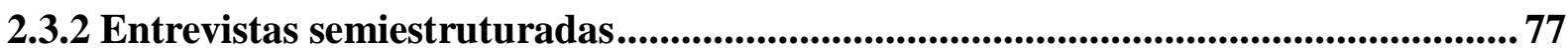

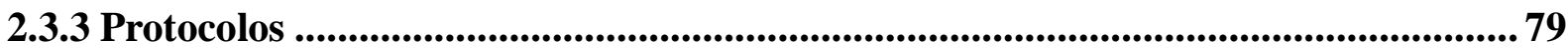

2.3.4 Novas ideias para a ampliação da coleta de dados......................................................... 80

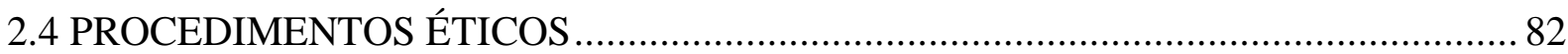

2.5 ESCOLA DE APLICAÇÃO DA UNIVERSIDADE DE SÃO PAULO: CONSIDERAÇÕES A RESPEITO DO CAMPO DE ATUAÇÃO ......................................... 82

2.5.1 Oficina Jogos Musicais: sua proposta e configuração....................................................84

2.5.2 Desenho metodológico da pesquisa .................................................................................... 87

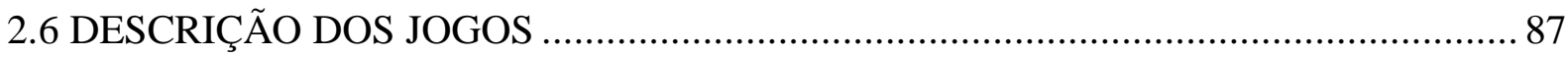

2.6.1 Jogo dos nomes: relógio maluco................................................................................ 89

2.6.2 Pega-congela sonoro ………….................................................................................91

2.6.3 Floresta e seus bichos .................................................................................................... 93

2.6.4 Jogo com a canção Bate o Monjolo ............................................................................95 
2.6.5 Criação 1 - Pega-pega animal........................................................................... 100

2.6.6 Criação 2 - Música................................................................................................. 102

2.6.7 Criação 3 - Detetive .......................................................................................... 104

2.6.8 Criação 4 - Competição de instrumentos ......................................................... 106

3 “É QUE VOCÊ SE DIVERTE MAIS BRINCANDO": O ENSINO E APRENDIZAGEM DA MÚSICA NO AMBIENTE DO JOGO CÊNICO-MUSICAL 108

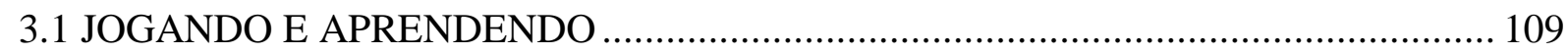

3.2 LIBERDADE E DESINIBIÇÃO: EXPERIÊNCIAS EM JOGO ................................... 112

3.3 “EU PENSEI QUE IA ESCREVER NA LOUSA” E “ACHEI QUE IA SER CHATA”: AS VIVÊNCIAS COM OS JOGOS CONTRAPONDO CONCEPÇÕES DE AULAS DE

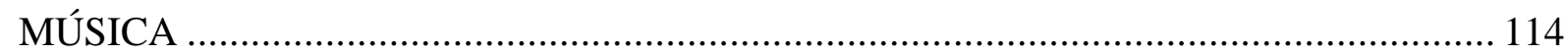

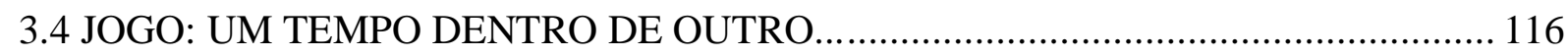

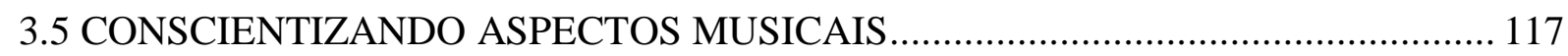

3.6 O "SOM DE LEÃO": O APRENDIZADO DA MÚSICA NOS JOGOS DE

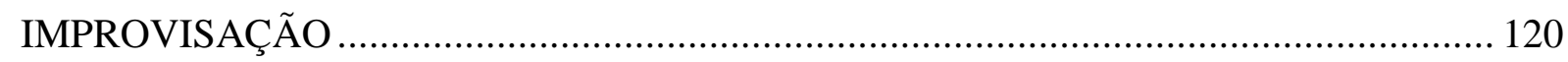

3.7 “EU APRENDI NOVOS JOGOS”: A AMPLIAÇÃO DE UM REPERTÓRIO.............. 127

3.8 "EU GOSTO DE INVENTAR OS MEUS PRÓPRIOS JOGOS”: O VALOR

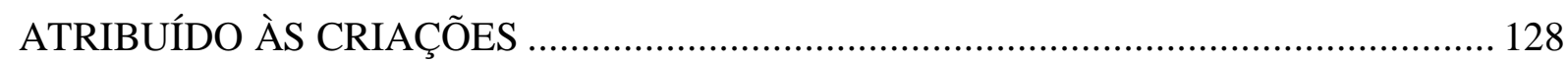

3.9 “A GENTE APRENDE A CONVIVER COM OUTRAS PESSOAS”: JOGAR PARA

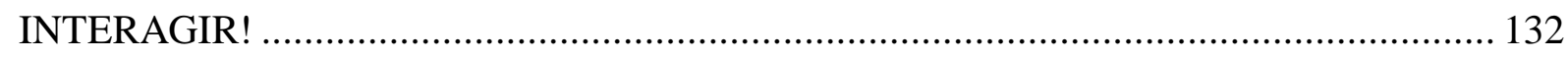

3.10 “ESSE NEGÓCIO DE MISTURAR AS IDADES TINHA QUE TER MAIS”: A OFICINA JOGOS MUSICAIS COMO ESPAÇO PARA INTEGRAÇÃO .......................... 135

3.11 “A GENTE FEZ NOVOS AMIGOS”: O TRABALHO COLABORATIVO E OS LAÇOS AFETIVOS POR MEIO DA EDUCAÇÃO MUSICAL ...................................... 138

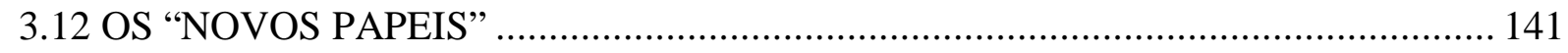

3.13 “NO MEU LIVRO EU ESCREVI QUE EU INVENTEI UM JOGO BEM LEGAL”.. 143 3.14 O “PIANO” SUBSTITUINDO OS “TRENS”, O DIÁLOGO AO INVÉS DAS BRIGAS: DOIS CASOS ESPECÍFICOS PARA ANÁLISE....................................................... 147

CONSIDERAÇÕES FINAIS .......................................................................... 155

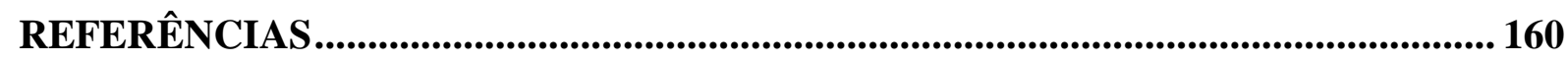

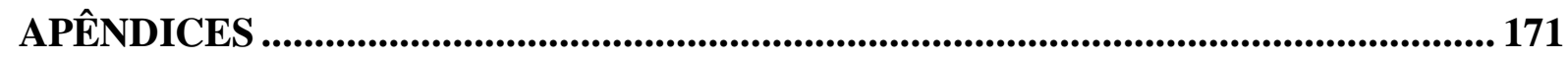




\section{INTRODUÇÃO}

Atuando como professora de música em diferentes contextos (escola regular, escola de música, organização não governamental e em projeto de extensão vinculado à Universidade do Estado de Santa Catarina - UDESC) entre os anos de 2008 e 2012, percebi o interesse das crianças pelos trabalhos de criação. Os momentos de exploração sonora, de improvisações e composições coletivas cativavam os alunos, independentemente da faixa etária deles. Recordo-me da alegria de muitas crianças enquanto elaboravam arranjos para as canções trabalhadas e apresentavam suas propostas à turma: era um momento de diálogo, de trocas, de compartilhamento das ideias e de fazer música juntos! Lembro-me do quanto eram significativas às crianças as criações em grupos, os trabalhos colaborativos, pois, para além das capacidades musicais, propiciavam um desenvolvimento das capacidades humanas. No decorrer das aulas, os próprios alunos destacavam a importância daqueles instantes, relatando que inventavam músicas e faziam novas amizades.

Outra questão que chamou minha atenção durante estes anos de trabalho foi o divertimento e aprendizado vivenciados no ambiente do jogo. Em um dos locais em que atuei, a chegada das crianças em sala era marcada pela euforia e pela constante pergunta: "qual é o jogo de hoje?”. Elas aguardavam ansiosas pelo momento do brincar, do jogar e, muitas vezes, ainda na semana anterior à aula, questionavam: “qual o jogo da próxima aula?”. Observando a sobrecarga de atividades impostas àquelas crianças (muitas tinham aulas no período da manhã, permaneciam na escola durante a tarde e seguiam para aulas particulares e/ou outras atividades à noite), acredito que o jogo consistia em um momento de "escape”. Era um espaço para o aprender brincando, para a diversão, um "local” onde laços afetivos se estabeleciam e onde o desmanche do "mapa estratégico ${ }^{1 \text { ” }}$ era corrente. Eram momentos em que não apenas reproduziam, mas criavam, experimentando jogos em que tinham voz e vez para inventar suas músicas e comandar suas ações.

\footnotetext{
${ }^{1}$ Termo trabalhado pelo filósofo Sílvio Gallo, que faz menção ao “mapa geográfico” da sala de aula: disposição das carteiras em filas, quadro/lousa à frente, dentre outros. Esta questão será tratada de maneira mais específica no capítulo 1 desta dissertação.
} 
Entre os anos de 2010 e 2012, participando de cursos na área de canto e artes cênicas, assim como integrando uma companhia de teatro musical da cidade de Florianópolis, envolvime com a temática dos jogos teatrais e com o trabalho de Viola Spolin. A partir de tais experiências, optei por realizar, em meu trabalho de conclusão de curso, uma pesquisa-ação voltada à prática dos jogos teatrais em aulas de canto a alunos do curso de licenciatura em música da UDESC.

Pesquisando acerca das temáticas expostas até então, encontrei o trabalho que Brito (2011) desenvolveu a respeito do pensamento pedagógico-musical de Hans-Joachim Koellreutter, catalogando os jogos de improvisação criados pelo educador. Vislumbrei nos jogos de Koellreutter a possibilidade de agregar, a um só tempo, os processos criativos, o jogo e elementos teatrais na educação musical. A partir de então, passei a pesquisar, recriar e desenvolver novos jogos, na perspectiva de realizar um trabalho com as crianças que abrangesse estes pontos.

Os fatores apresentados conduziram a escolha da temática desta dissertação de mestrado. Observando o prazer das crianças ao criarem músicas, ao representarem papeis, ao jogarem com personagens e sons, pensei acerca dos jogos de improvisação cênico-musicais como espaços para a criação na sala de aula.

A importância dos processos criativos no ensino e aprendizagem da música vem sendo apontada ao longo do tempo. No século XX, principalmente após a década de 1960, emergiram propostas pedagógico-musicais que enfatizaram o valor da criação, destacando-se, dentre estas, abordagens de compositores como John Paynter, Hans-Joachim Koellreutter e Murray Schafer (FONTERRADA, 2008). As contribuições destes educadores proporcionaram novos debates e reflexões acerca das práticas de composição e improvisação, relacionando-as à possibilidade de desenvolvimento musical e humano por meio da educação musical.

O jogo e as possíveis relações deste contexto lúdico com a educação também são investigados por autores como Brougère (1998, 2012), Lima (2008), Luckesi (2000, 2002) e Pereira (2004). Compreendendo-o como um espaço para liberdade, incertezas e aprendizados, profissionais como Koudela (2009), Pereira (2012) e Spolin (2008, 2012) pensaram sua prática no ensino e aprendizagem do teatro.

No ensino da música, entretanto, percebe-se ainda a presença de materiais didáticos que estruturam sistematicamente os conteúdos a serem trabalhados em sala, pensando-os como conhecimentos a serem transmitidos aos alunos via professor. Deste modo, tornam-se 
recorrentes, em muitas instituições, as metodologias que mantém um padrão conservador e que prescindem de questões importantes à educação musical (BELLODI, FONTERRADA, 2006, p. 923). O processo pedagógico-musical carece, em muitos contextos, do estímulo à criação, além de mostrar-se desvinculado de práticas lúdicas (BELLODI, FONTERRADA, 2006, p. 924).

A meu ver, as metodologias de educação musical no Brasil ainda não abarcam trabalhos na dimensão do fichário de Viola Spolin (2012), por exemplo, em que são apresentadas fichas com a descrição de 160 jogos voltados ao ensino do teatro (jogos como espaço de criação e improvisação). Na busca por materiais, é possível encontrar livros que apresentam o ensino e aprendizagem da música por meio de brincadeiras e jogos. Porém, muitos destes materiais ainda estão associados a uma concepção de jogo como "instrumento didático”, em que conteúdos considerados importantes são repassados de maneira mais “dinâmica” aos alunos. Nesta perspectiva, algumas abordagens desconsideram os processos criativos ou, ainda, estão atreladas a uma concepção de jogo como espaço de certezas, e não como espaço de liberdade, criação e incertezas.

Ainda que em menor número, os jogos de Koellreutter parecem-me compor um trabalho que abrange a criação dentro da incerteza do jogo, além de elementos teatrais, consistindo em importante material para esta pesquisa. Em conversa com a professora Dra. Teca Alencar de Brito a respeito dos jogos desenvolvidos por Koellreutter, ela ressaltou a possibilidade do educador ter lido o material de Viola Spolin e se inspirado nele para a criação de seus jogos. Dois motivos foram apresentados para esta hipótese: (1) Koellreutter, durante toda sua trajetória como músico e educador, estudou obras de diversas áreas, tais como física, psicologia e filosofia. O próprio educador comentava que não "lia”, mas “estudava” tais obras, relendo-as, analisando-as e aplicando os aspectos que considerava importantes ao trabalho que desenvolvia na área da música. Koellreutter (1997c, p. 134) afirmava: "a tendência de todos os trabalhos que fiz foi sempre a interdisciplinaridade. Sempre me autoeduquei neste sentido”. Nesta perspectiva, é possível que o educador, estudando materiais relacionados às artes, assim como de outras áreas do conhecimento, tenha encontrado o trabalho desenvolvido por Viola Spolin acerca do jogo e da improvisação no teatro. (2) Na descrição de seus jogos, Koellreutter segue uma estrutura bastante parecida com a usada por Viola Spolin. O educador aponta a temática a ser trabalhada e os objetivos, sugere uma divisão dos participantes em jogadores e plateia, descreve como se dá a realização do 
jogo, indica critérios para a avaliação, além de levantar considerações acerca da atuação do professor e dos alunos, assim como do que deve ser trabalhado antes, durante e após os momentos de improvisação - considerações semelhantes às “instruções” e às "notas” presentes no material de Spolin (2012a, 2012b).

Além dos aspectos apresentados acima, muitos dos jogos de Koellreutter sugerem personagens e o local imaginário da realização da ação (semelhantes à escolha do “onde”, “quem” e “o quê” nos jogos de Viola Spolin). Ainda é possível observar que, em algumas variações propostas em seus jogos e em sugestões feitas pelo educador, consta a realização do jogo como uma peça de teatro.

Nesta perspectiva, as proposições pedagógicas de Koellreutter nortearam este estudo, que intenta relacionar discussões a respeito dos processos criativos e do jogo na educação musical, estabelecendo cruzamentos também com autores da área do teatro. Iniciou-se este trabalho a partir da seguinte questão de pesquisa: quais as contribuições das experiências de improvisação musical em jogos cênico-musicais para a formação integral da criança?

Por formação integral, entende-se aquela que é voltada para além do musical, visando tanto o desenvolvimento de capacidades musicais quanto de capacidades humanas.

\begin{abstract}
Entende-se por formação integral aquela voltada para além do musical. Um trabalho com a música pode, por um lado, integrar corpo e mente, razão e emoção, sensibilidade e intelecto. Por outro lado, no entanto, a prática musical coletiva, além de propiciar a vivência da dimensão estética, da potência do sensível, da arte, favorece a convivência com o outro, o respeito, o aprender a escutar, aspectos como a autodisciplina, a submissão dos interesses próprios aos do grupo, o trabalho em equipe, entre diversas outras possibilidades (ZANETTA; BRITO, 2013, p. 10261027).
\end{abstract}

Brito (2010, p. 92-93) afirma que a realização musical reflete consciências e que, ao fazermos música, qualificam-se características humanas. A autora acredita que os projetos de educação musical devem se preocupar com o fortalecimento das relações humanas, pensandose um trabalho que desenvolva a relação com o outro, com o mundo e a relação consigo mesmo. Tais aspectos devem constituir, segundo Brito (2010, p. 93), “o cerne dos projetos de educação musical”.

Penso que, atualmente, são necessárias discussões a respeito da formação integral por meio da educação musical, estimulando reflexões acerca do valor da música para a sociedade e sua importância para o ser humano. Fonterrada (2008, p. 105) comenta que “o que importa, 
no momento atual, é discutir o valor da música para a sociedade. A indústria cultural tem vendido a ideia de música como entretenimento e lazer, e é necessário o resgate da discussão da importância da arte - e da música - para o ser humano”.

Vale ressaltar, portanto, que o conceito de formação integral nesta pesquisa não está relacionado, de maneira alguma, à ideia de se valer da música como atividade complementar aos currículos e conteúdos escolares, como auxílio ou benefício às aprendizagens consideradas prioritárias. Também não se refere à integração entre música e teatro presente nos jogos cênico-musicais propostos (e que serão apresentados) neste trabalho ${ }^{2}$. O conceito de formação integral através da educação musical trata-se, portanto, do que foi exposto anteriormente: pensar o processo da música em sala de aula voltado para além do musical, para o desenvolvimento das capacidades humanas.

\footnotetext{
O mais significativo na educação musical é que ela pode ser o espaço de inserção da arte na vida do ser humano, dando-lhe possibilidade de atingir outras dimensões de si mesmo e de ampliar e aprofundar seus modos de relação consigo próprio, com o outro e com o mundo. Essa é a real função da arte e deveria estar na base de toda a proposta de educação musical (FONTERRADA, 2008, p. 117).
}

Objetivando investigar as possíveis contribuições dos jogos de improvisação para a formação integral das crianças, propôs-se uma pesquisa-ação, cuja prática consistiu em uma Oficina de Música voltada a crianças entre sete e dez anos de idade ${ }^{3}$. Esta Oficina foi realizada na Escola de Aplicação da Faculdade de Educação da Universidade de São Paulo (EAFEUSP), atendendo doze alunos desta instituição. Fez-se o registro das aulas em material audiovisual, entrevistas semiestruturadas com as crianças, entrevista semiestruturada com uma das professoras de música da EAFEUSP e confecção de protocolos a cada novo encontro, sendo estes os procedimentos de coleta de dados. Os materiais coletados permitiram compreender as ideias das crianças a respeito de uma Oficina de Música que esteve voltada a vivência de jogos de improvisação cênico-musicais.

A dissertação está organizada em três capítulos. O primeiro capítulo, sob a ótica de autores como Brito (2007), Deleuze (1997), Fonterrada (2008), Foucault (1999), Freire (1983,

\footnotetext{
${ }^{2}$ A descrição destes jogos consta no capítulo 2 desta dissertação.

${ }^{3}$ Uma das crianças participantes estava prestes a completar sete anos.
} 
1996) e Gallo (2004, 2008, 2014), expõe a existência de um descompasso na área educacional, apontando as críticas de alguns educadores a respeito dos processos pedagógicos, do modelo de escola vigente, dentre outras questões relacionadas à educação, e a persistência destas “questões problemáticas” ainda nos dias de hoje. A ideia de um trabalho que envolva os processos criativos e o jogo na educação musical é apresentada, buscando-se uma redução do descompasso citado. Considerando a ampla atuação de Koellreutter no campo da educação musical, suas contribuições ao pensar o ensino e aprendizagem da música por meio dos jogos de improvisação, além das relações que podem ser estabelecidas entre o pensamento do educador e dos autores apresentados neste capítulo, algumas de suas proposições pedagógico-musicais serão abarcadas.

O segundo capítulo abrange questões referentes à metodologia de pesquisa, tais como a abordagem qualitativa do trabalho, o método pesquisa-ação e os instrumentos de coleta de dados. Exponho também considerações a respeito da Escola de Aplicação como campo de pesquisa, dos procedimentos éticos, da proposta da Oficina de Música “Jogos Musicais” e os objetivos almejados por meio desta prática. Por conseguinte, os jogos realizados no decorrer da Oficina (tanto aqueles desenvolvidos por mim quanto os jogos criados pelas crianças participantes da pesquisa) são descritos, explicando-se a estrutura e o funcionamento dos mesmos.

O capítulo 3, por fim, contém a análise de dados. As falas dos alunos, suas ações/reações durante os jogos e as reflexões por eles levantadas durante as entrevistas foram apresentadas, buscando a perspectiva das crianças para as considerações que seriam erguidas no trabalho. Os diálogos que emergiram no decorrer das entrevistas em grupo foram transcritos e propiciaram cruzamentos com o pensamento de diferentes autores. A partir das falas das crianças, expostas no decorrer do capítulo, pôde-se observar que a vivência em jogos de improvisação cênico-musicais propiciou o desenvolvimento de capacidades musicais e humanas. Como indicam, respectivamente, Fernanda e Patrícia (alunas participantes da pesquisa), “A gente aprende a ouvir, a tocar e a saber como a gente faz a música.” Porém, “a gente aprende além de música. A gente aprende jogos novos. E a gente aprende a brincar juntos!”. 


\section{PROPOSIÇÕES PEDAGÓGICO-MUSICAIS E OS DESCOMPASSOS NA EDUCAÇÃO: FISSURAS EXISTENTES FRENTE ÀS NOVAS QUESTÕES}

Um mundo em constante mudança, caracterizado por frequentes reorganizações do pensamento humano: novas concepções, transformações contínuas, novos olhares. Um “mundo em disparada” (GIDDENS, 2002). Para Freire (1996), um mundo que não é, mas está sendo. Neste cenário de intenso dinamismo e pluralismo/coexistência de ideias, as nossas mais diversas percepções se fazem presentes e, consequentemente, ininterruptas e distintas interpretações. Em contínuo movimento, formam-se visões de mundo que, em um processo dinâmico, transformam-se, reorganizam-se.

\footnotetext{
Esse conjunto de mudanças rápidas alcança o homem, a sociedade, e afeta as ações e o próprio modo de ser de cada um, pedindo por reajustes e soluções. A rapidez com que as coisas sucedem na época atual, a modificação de conceitos clássicos, como os de tempo e espaço, e a velocidade com que se entra em comunicação com qualquer ponto do planeta para obter informações tornam, ao mesmo tempo, as coisas obsoletas, atropelam o usuário com avalanches de dados e limitam o espaço da linearidade [...] Vive-se um momento de ruptura, em que conceitos, valores e crenças, até há pouco considerados inquestionáveis, encontram dificuldade em se manter, sendo rapidamente substituídos ou alterados (FONTERRADA, 2008, p. 280).
}

Brito (2007), ao versar sobre a segunda metade do século XX, também faz menção a este constante movimento, a estas rápidas mudanças e ao surgimento de reflexões teóricas em áreas relacionadas às ciências, às artes e à educação, cenário que, segundo a autora, conduz a uma movimentação das maneiras de olhar e significar a existência. Nesta perspectiva, Brito (2007) considera a necessidade de acompanharmos o fluxo dinâmico do pensamento ao reordenarmos olhares, repensarmos e ressignificarmos nossos objetos de estudo.

Diversos campos de estudo são afetados por estas mudanças, tendo em vista o surgimento de novas teorias e visões de mundo. Busca-se abarcar, portanto, nas distintas áreas do conhecimento, os novos olhares, as modificações que transpassam o pensamento humano. Como aponta Fonterrada (2008, p. 280), “profundas mudanças vêm se impondo, e obrigam a buscar outras matrizes de pensamento, capazes de dar conta dessas alterações”.

As áreas da educação e da educação musical - às quais dirigirei maior atenção nesta pesquisa - também têm sido atravessadas por modificações com o passar do tempo. Diversos 
estudiosos e pesquisadores (tais como Mário Cortella, Paulo Freire e Sílvio Gallo) apontaram suas ideias e reflexões, contribuindo com este processo de constantes intervenções. Entretanto, nota-se certo descompasso entre o pensamento exposto por estes nas últimas décadas e o modelo de escola (assim como de procedimentos pedagógicos) que ainda se faz presente. Considerando-se as inúmeras reflexões produzidas nas últimas décadas (por exemplo, as questões abordadas por Paulo Freire e Rubem Alves na educação, assim como aquelas erguidas por Hans-Joachim Koellreutter e Murray Schafer na educação musical) e as efetivas práticas em sala de aula atualmente, percebe-se tal descompasso entre ideias e ações.

Ramos (2012) evidencia este descompasso no sistema educacional. Para este professor, "o Brasil ainda tem uma escola do século XIX, professores do século XX e alunos do século XXI” (RAMOS, 2012, s/p). Este “choque secular” tem sido debatido entre diferentes profissionais. Para o filósofo Cortella (2014, s/p), “não há problema no fato de que os alunos sejam do século XXI, nós sejamos do século XX e alguns métodos do século XIX, se uma parte disso não fosse anacrônica. Porque uma parte é”. A questão principal, a seu ver, é a existência de elementos do passado que já não condizem com este século. Logo, caso estivéssemos vivenciando elementos que ainda fizessem sentido, não haveria problema. $\mathrm{O}$ problema é estarmos fora do tempo, à medida que subsistem “elementos do passado que já não têm mais vitalidade no século XXI” (CORTELLA, 2014, s/p). De tal modo, o filósofo apresenta a ideia de anacronismo e de um “choque intersecular”.

\begin{abstract}
Atualmente, temos um choque de séculos, de tempos, dentro da sala de aula e isso faz com que o trabalho pedagógico seja, por vezes, anacrônico [...] a escola anacrônica tem o olhar voltado ao passado, já ultrapassado. Por isso que, quando se imagina essa condição, esse choque intersecular expressa uma não realização dos objetivos sociais, individuais e éticos que a escola precisa fazer. Há aí uma profunda quebra de tempo que é bastante negativa (CORTELLA, 2014, s/p).
\end{abstract}

Vélez (2012), ao tratar das escolas da América Latina, expõe uma caricatura que, a seu ver, deve ser rompida: "é o professor em um quadro negro dando aulas. Em pleno século XXI, isso não tem sentido” (VÉLEZ, 2012, s/p). Para Colbert (2012, s/p) “o conhecimento está mudando permanentemente. Então, o que aconteceu foi que os sistemas educacionais não têm mudado tão rapidamente quanto o resto da sociedade. É aí que está o problema de fundo”.

Observam-se, no decorrer da história, educadores e filósofos que pensaram a respeito da estrutura da escola, dos processos de ensino e aprendizagem, dos meios de avaliação, 
dentre outras questões vigentes no sistema educacional. Entretanto, apesar dos apontamentos destes estudiosos, a escola permanece reproduzindo hábitos questionados e criticados ao longo do tempo, vivenciando, assim, o descompasso citado.

O filósofo francês Michel Foucault (1926-1984), por exemplo, expôs as relações entre o conhecimento e o poder, indicando-nos que as instituições utilizam ambos como forma de controle social. Em sua obra Vigiar e Punir: nascimento da prisão, datada de 1975, Foucault analisou a vigilância e a punição presentes em entidades estatais, dentre estas as prisões e as escolas. O filósofo avaliou a disciplina como fabricante de corpos submissos, corpos dóceis (FOUCAULT, 1999, p. 110) e, por fim, demonstrou a presença desta disciplina na escola.

Foucault já expunha, em 1975, a educação e seus mecanismos de controle, pensando acerca da estrutura arquitetônica da escola (comparando-a com a prisão e traçando semelhanças entre seus sistemas de vigilância), da fragmentação do conhecimento (a seu ver, forma de dominar e controlar o que os estudantes sabem) e da disciplinarização (exercício de poder presente e que se manifesta, até mesmo, na disposição física e organizacional de uma sala de aula).

Foucault denunciou os mecanismos mais explícitos da escola, quando traçou em Vigiar e Punir os paralelos desta instituição social com a prisão. Mostrou que a estrutura física e arquitetônica da escola está voltada, assim como na prisão, para a vigilância/controle de seus alunos/prisioneiros. São muitos os olhos que sentimos sobre nós, o que introjeta o controle e faz com que nós próprios nos vigiemos. Mas o filósofo francês também apontou outros mecanismos da escola muito menos explícitos, como a disciplinarização. Por detrás dela, paira o controle: compartimentalizando, fragmentando, é muito mais fácil se controlar o acesso, o domínio que os alunos terão e também se controlar o que eles sabem. Outro aspecto deste termo ambíguo não por acaso, a disciplinarização, diz respeito mais diretamente à questão do poder. A escola é o lugar da disciplina, de seu aprendizado e de seu exercício. Não vai longe o tempo em que os alunos faziam, nos pátios das escolas públicas, antes de entrar em aula, exercícios de ordem unida, como recrutas num quartel. A disposição de carteiras numa sala de aula, por outro lado, visa também à disciplinarização dos alunos e uma melhor possibilidade de controle por parte do professor, que domina geopoliticamente a classe, percebendo seu mapa geográfico e podendo armar uma estratégia/tática de aula. Todo o mapa estratégico é cuidadosamente preparado (GALLO, 1995, p. s/p).

O educador e filósofo brasileiro Paulo Freire (1921-1997) também refletiu a respeito das estruturas presentes na escola. Autor de obras de referência na área da educação, tais como Pedagogia do oprimido (1983), Pedagogia da autonomia: saberes necessários à prática educativa (1996) e Educação como prática de liberdade (1999), Freire (1983) expôs a prática bancária nos processos pedagógicos: os educandos como recipientes que recebem 
“depósitos” do educador. Deste modo, critica as relações entre educador-educando, apontando o caráter narrativo existente, a falta de diálogo na educação e o ato de depositar saberes.

\begin{abstract}
A narração, de que o educador é sujeito, conduz os educandos à memorização mecânica do conteúdo narrado. Mais ainda, a narração os transforma em "vasilhas", em recipientes a serem "enchidos” pelo educador. Quanto mais vá "enchendo" os recipientes com seus "depósitos", tanto melhor educador será. Quanto mais se deixem "docilmente" encher, tanto melhor educandos serão. Desta maneira, a educação se torna um ato de depositar, em que os educandos são os depositários e o educador o depositante. Em lugar de comunicar-se, o educador faz "comunicados" e depósitos que os educandos, meras incidências, recebem pacientemente, memorizam e repetem. Eis aí a concepção bancária da educação, em que a única margem de ação que se oferece aos educandos é a de receberem os depósitos, guardá-los e arquiválos (FREIRE, 1983, p. 66).
\end{abstract}

A concepção bancária de educação, mantendo e estimulando a contradição entre educadores como detentores do saber e educandos como os que recebem conhecimento, reflete uma sociedade opressora, sendo “dimensão da cultura do silêncio” (FREIRE, 1983, p. 67). Para o autor, trata-se de um processo de “domesticação”, formador de indivíduos “passivos”. Novamente, portanto, podem-se pensar as estruturas de poder e disciplinarização presentes na escola, já expostas por Foucault (1999).

Freire (1983) expôs a educação bancária a serviço da domesticação e opressão, indicando também caminhos para a mudança desta prática na escola. O educador salientou, em diversos momentos, a necessidade de superação da contradição entre educadoreseducandos, empregando-se uma conciliação entre estes, de maneira que ambos sejam, simultaneamente, educadores e educandos. Segundo o autor, “a razão de ser da educação libertadora está no seu impulso inicial conciliador” (FREIRE, 1983, p. 67).

No momento em que o educador bancário vivesse a superação da contradição já não seria bancário. Já não faria depósitos. Já não tentaria domesticar. Já não prescreveria. Saber com os educandos, enquanto estes soubessem com ele, seria sua tarefa. Já não estaria a serviço da desumanização. A serviço da opressão, mas a serviço da libertação (FREIRE, 1983, p. 71).

O professor e filósofo brasileiro Sílvio Gallo (1963-) é outro profissional que pode ser mencionado, tendo em vista seus apontamentos acerca das problemáticas da educação na atualidade. Autor de obras como Pedagogia do Risco: experiências anarquistas em educação (1995), Deleuze e a educação (2008), Pedagogia Libertária: anarquistas, anarquismos e educação (2007), dentre diversas outras, Sílvio Gallo atua com ênfase na filosofia da 
educação, pesquisando a filosofia francesa contemporânea e estabelecendo elos entre autores como Gilles Deleuze (1925-1995), Félix Guattari (1930-1992) e Foucault com a educação.

Gallo (2014b) propõe reflexões a respeito desta educação que é gerida e mediada pelo Estado, expondo as consequências deste vínculo. Versa a respeito de uma pedagogia anarquista ou pedagogia do risco, na contramão do que chama de pedagogia da segurança, propondo uma abertura ao risco ao invés da "segurança" dos métodos educacionais. Em seus textos e entrevistas, o filósofo aborda questões referentes aos processos de ensino e aprendizagem atuais, tais como a avaliação na escola - considerando esta, assim como Foucault (1999), uma medida de controle e dominação.

\begin{abstract}
A educação tem sido, desde suas origens, um processo social de transmissão da cultura. Ora, parte-se então do princípio de que alguém transmite e alguém recebe essa transmissão; é preciso controlar esse processo, o que é feito através da avaliação. Numa sociedade de dominação e exploração, infelizmente a única realidade histórica que conhecemos, a avaliação aparece como um instrumento de controle social, de regular quem aprende o que e como, com que propósito. Foucault, por exemplo, desvendou os mecanismos de funcionamento da avaliação, dos exames, numa sociedade disciplinar. Deleuze, por sua vez, insinuou que os instrumentos de avaliação contínua e formação permanente, parte dos discursos educacionais hegemônicos hoje, são decorrentes daquilo que ele chamou de 'sociedades de controle', que sucederiam as ‘sociedades disciplinares' estudadas por Foucault. Podemos dizer, então, que a educação hoje, cujos processos de ensino e aprendizagem estão completamente assentados na avaliação, cumprem suas funções precípuas de disciplinamento e de controle (GALLO, 2014b, s/p).
\end{abstract}

Pensando filosoficamente a educação, com suas constantes análises acerca deste modelo de escola que ainda hoje está em voga, o autor traz imensas contribuições para a área da educação - área que, segundo ele mesmo coloca, sempre andou junta à filosofia, mas “com a tecnificação do mundo moderno, elas foram separando-se e distanciando-se” (GALLO, 2004, p. 80). Para tais reflexões, este pesquisador vem se amparando também na obra de Gilles Deleuze - tanto nas produções “solo” quanto nas produções em parceria com Félix Guattari - ainda que Deleuze nunca tenha escrito sobre educação (GALLO, 2008, p. 9). Deste modo, percebe-se que as contribuições para uma área podem advir de profissionais de outros campos. Gallo (2008, p. 9) escreve a respeito disto: “ousadamente, diria que talvez aqueles que não explicitamente se debruçaram sobre a problemática educacional tenham mais a dizer aos educadores do que podemos imaginar”.

Ao estudar as obras de Gilles Deleuze, Gallo (2008) faz aproximações com a educação e opera por deslocamentos, permitindo uma recriação de conceitos e novas significações. 
Desta forma, determinados conceitos deleuzianos (alguns desenvolvidos em conjunto com Félix Guattari), tais como literatura menor e rizoma, são “roubados”, desterritorializados da obra de Deleuze e aplicados ao campo da educação, pensando-se a implicação destes conceitos para a área.

Estes "roubos", entretanto, são considerados, por Deleuze, como uma atitude criativa (GALLO, 2000, 2008). Como coloca Gallo (2000, p. 49), "no universo deste filósofo o roubo de conceitos é uma atitude extremamente criativa: retomar um conceito filosófico é recriá-lo, é dar-lhe novas e antes insuspeitas - às vezes, até mesmo improváveis - significações”. Assim sendo, parafraseando Bob Dylan, Gilles Deleuze considera que "roubar é o contrário de plagiar, de copiar, de imitar ou de fazer como” (DELEUZE apud GALLO, 2000, p. 50).

Os deslocamentos conceituais realizados por Gallo (2008) permitiram novas significações, tais como a de educação menor. Apropriando-se do conceito de literatura menor (desenvolvido por Deleuze e Guattari no livro "Kafka: por uma literatura menor”), Gallo (2008) deslocou-o para outro território, buscando um devir-Deleuze na educação.

Uma prática menor é compreendida como uma prática das minorias, que resiste aos mecanismos de controle e de massificação. Menor, para Schollhammer (2002, p. 63), “é aquela prática que assume sua marginalidade em relação aos papéis representativos e ideológicos da língua e que aceita o exílio no interior das práticas discursivas majoritárias, formulando-se como estrangeiro na própria língua”. Uma literatura menor, portanto, “não é a de uma língua menor, mas antes a que uma minoria faz em uma língua maior” (DELEUZE, GUATTARI, 1977, p. 25). Para estes filósofos, “‘menor’ não qualifica mais certas literaturas, mas as condições revolucionárias de toda literatura no seio daquela que chamamos de grande (ou estabelecida)” (DELEUZE, GUATTARI, 1977, p. 28).

Deslocando este conceito, Gallo (2008) criou o que intitulou de educação menor: uma educação que é ato de resistência e revolta, que se constitui como atividade de militância, que busca suas linhas de fuga, que investe na produção de singularidades e anda na contramão dos processos de massificação. Consiste em uma "revolta contra os fluxos instituídos, resistência às políticas impostas; sala de aula como trincheira [...] como espaço a partir do qual traçamos nossas estratégias, estabelecemos nossas militâncias, produzindo um presente e um futuro aquém ou para além de qualquer política educacional” (GALLO, 2008, p. 64-65). 
Ao ser entrevistado por Miguel Ângelo do Carmo, o autor comenta acerca da educação menor e da produção conceitual deleuziana. Esta parece, a seu ver, interessante aos que buscam uma prática educativa que invista nas singularidades.

\begin{abstract}
Nessa atividade de militância, daquilo que eu chamaria - parafraseando Deleuze e Guattari - de uma 'educação menor', aquela que se faz na sala de aula, para além e para aquém de toda e qualquer política educacional, a produção conceitual deleuziana parece-me interessante. Parece ser potencializadora e efetivamente criadora, para aqueles que buscam uma prática educativa aberta às diferenças, que invista na produção de singularidades, na contramão dos processos de subjetivação (leia-se massificação) levados a cabo pela poderosa máquina capitalística. (GALLO, 2014b, s/p).
\end{abstract}

De acordo com Gallo (2008, 2014), a educação menor é máquina de resistência. A educação maior, por sua vez, é a instituída, “aquela dos planos decenais e das políticas públicas de educação, dos parâmetros e das diretrizes, aquela da constituição e da Lei de Diretrizes e Bases da Educação Nacional, pensada e produzida pelas cabeças bem-pensantes a serviço do poder" (GALLO, 2008, p. 64).

A pesquisadora e educadora musical Teca Alencar de Brito (1954-) também trabalhou com conceitos deleuzianos, assim como com as ressignificações propostas por Gallo (2008), operando, igualmente, por deslocamentos. Brito (2007) propôs uma educação musical em modo menor: "modo que é resistência, que é pensamento, que é singularidade; modo que é linha de fuga, resistindo aos mecanismos de controle dos meios de comunicação, cuja ênfase é o produto feito e nunca o estímulo ao processo” (BRITO, 2007, p. 6).

Por meio de seus estudos, Brito (2007) contribuiu para a percepção da educação musical também "como um espaço do modo maior, caracterizado pela presença de métodos e sistemas que se fecham sobre si mesmos e que visam à mera aquisição de competências para fazer música dentro de padrões tradicionais (maiores) de um meio cultural em questão” (BRITO, 2007, p. 7).

Em sua pesquisa, a educadora aponta para um redimensionamento de procedimentos pedagógicos nas aulas de música com crianças por considerar que a criança vive um modo menor de fazer e significar a música. Desta forma, propõe uma educação musical em modo 
menor - também nomeada pela autora como uma educação do Pensamento ${ }^{4}$ - "em contraposição aos modelos tradicionalistas estabelecidos, quer nos sistemas de comunicação midiáticos, quer nos planos da educação” (BRITO, 2007, s/p).

\begin{abstract}
Uma educação musical em modo menor implica em reconhecer, em primeiro plano, o modo menor musical da criança: modo que concerne aos jogos infantis de construção dos planos de organização musicais. Um modo menor musical é um modo singular de lidar com as ideias de música que reinventa relações e sentidos com o sonoro e o musical, tornando-se, também, máquina de resistência ao controle e aos modelos dominantes (BRITO, 2007, p. 7).
\end{abstract}

Brito (2007, p. 7) também salienta que a criança vive um “'modo menor’ de ser e significar a existência” e que as instituições, tanto escolar quanto familiar, fortalecem um modo maior de educar. Logo, segundo a autora, a criança "vive um contínuo e dinâmico territorializar - do menor para o maior” (BRITO, 2007, p. 7).

A pesquisadora propõe, portanto, que se volte atenção ao "modo menor" musical da criança, atentando para suas ideias de música, favorecendo "exercícios do pensar, em contraposição aos modelos tradicionalistas de ensino que priorizam a inteligência” (BRITO, 2007, p. 8).

Bem mais do que treinar competências específicas necessárias às realizações musicais (que via de regra aconteceriam em tempo futuro), uma educação musical do pensamento propõe jogos do pensar, mergulhando no inconsciente em que perceptos, afectos e conceitos produzem multiplicidades; onde intuir, sentir, produzir movimentos, estão sempre na ordem do dia. Com sons, silêncios e escutas... de toda sorte. Tal proposta implica na fundação de territórios que podemos instaurar trabalhando com idéias de música como acontecimento, como processos

\footnotetext{
${ }^{4}$ A autora trabalha com os conceitos de pensamento e inteligência como distintos, embasando-se na perspectiva deleuziana e no trabalho de Carlos Ulpiano (1993) para fundamentar esta questão. Inclusive, o termo "Pensamento" é iniciado com letra maiúscula, pois assim Gilles Deleuze o apresenta, diferenciando-o do que se entende, tradicionalmente, por pensamento. Segundo Ulpiano (1993, p. 8), o pensamento difere da inteligência por entrar em contato com os conceitos - enquanto a inteligência entra em contato com os objetos da ciência. Tanto Ulpiano (1993) quanto Brito (2007) referem-se à inteligência "apontando para as suas características funcionais de eficiência e de realização, que nada teriam a ver com o mergulho no caos que o pensamento propicia” (BRITO, 2007, p. 8). Assim sendo, a autora propõe uma educação musical em modo menor, também chamada educação musical do Pensamento, "em oposição àquela que visa à inteligência: limitada à transmissão de conceitos e informações; preocupada em treinar o desenvolvimento de competências técnicas; ensinando a repetir o igual; padronizando, desconfigurando, guiando-se pelo tempo relógio que comanda e determina percursos e atividades” (BRITO, 2007, p. 259). Visa, portanto, uma educação não limitada ao ato de transmitir conceitos, buscando instaurar "planos favoráveis à atitude da filosofia que, segundo Deleuze e Guattari, "tem uma ação criadora (de conceitos) e não é uma mera passividade frente ao mundo' (GALLO, 2003, p.41).” (BRITO, 2007, p. 156).
} 
desencadeadores de devires, como jogo que se dá no "entre-lugar" do estabelecido (BRITO, 2007, p. 8).

Assim como Brito (2007), outros autores apontaram problemáticas da educação musical. Dentre estes, pode-se citar o alemão - naturalizado brasileiro - Hans-Joachim Koellreutter (1915-2005), considerando suas inúmeras reflexões e críticas acerca dos processos de ensino e aprendizagem da música.

O compositor e educador H-J. Koellreutter enfatizou a importância da criação nas artes, destacando a improvisação musical como ferramenta pedagógica. Para ele, "sem o espírito criador não há arte, não há educação. É esta uma verdade que os educadores tão facilmente esquecem” (KOELLREUTTER, 1997b, p. 53). Destacou, assim, o valor da criação nas aulas de música, considerando que as experiências de criação e improvisação proporcionavam espaços para conscientizar questões musicais e humanas. Logo, vislumbrou a improvisação como meio para promover um ambiente de trocas, defendendo-a como prática que permitiria trabalhar e desenvolver a autodisciplina, a tolerância, o respeito - dentre outras capacidades humanas, juntamente aos aspectos musicais (BRITO, 2011).

Koellreutter buscou a superação da dicotomia professor versus aluno e a instauração do sentido coletivista na música - almejando substituir o individualismo e as relações egocêntricas existentes no meio artístico pela noção de coletividade e interação (ZANETTA, 2014a). Criticou o ensino de música no Brasil, denunciando uma estagnação deste e o enraizamento de métodos (KOELLREUTTER, 1997a). O educador valorizava, ao invés de métodos e de uma padronização do ensino, os espaços para a criação e para o debate na educação. “'Meu método é não ter método’, disse-nos o professor inúmeras vezes. 'O método fecha, limita, impõe... e é preciso abrir, transcender, transgredir, ir além...”” (BRITO, 2011, p. 31). Por conseguinte, afirmava que os professores deveriam aprender a apreender dos alunos o que deveria ser trabalhado em aula, de maneira que os assuntos abordados partissem do interesse dos estudantes (BRITO, 2011).

Uma de suas propostas foi o que chamou de ensino pré-figurativo (em alusão ao termo figurativo, de domínio das artes plásticas): um ensino não baseado em moldes, métodos preestabelecidos, livre de preconcepções, aberto para que se construísse um caminho durante o próprio caminhar. Assim, considerou a necessidade de um sistema educacional em que não se "educasse" no sentido tradicional, mas em que se conscientizasse e orientasse os alunos através do diálogo e do debate (KOELLREUTTER apud BRITO, 2011, p. 37). 
Observando as proposições koellreutterianas, podem-se estabelecer relações com as ideias erguidas pelo educador Paulo Freire. A busca pela superação da dicotomia professor versus aluno está presente no discurso de ambos, assim como a importância dada ao diálogo nos processos de ensino e aprendizagem. Tanto H-J. Koellreutter quanto Paulo Freire valorizavam o debate nas aulas, dando ênfase a uma educação problematizadora e apontando para a formação de sujeitos críticos e reflexivos. Koellreutter (apud BRITO, 2011, p. 34) afirmava: "O mais importante é - sempre - o debate e, nesse sentido, os problemas que surgem no decorrer do trabalho interessam mais que as soluções”.

Assim como Freire (1983) criticou a educação bancária, constituída por um detentor do saber que transmite conhecimentos aos que, supostamente, nada sabem, Koellreutter (1997c) ergueu a necessidade de apreender do aluno o que deve ser trabalhado em aula. O professor ressaltava: “a minha maneira de trabalhar parte sempre do aluno, dele para mim, e não o contrário. O assunto das aulas resulta sempre de um diálogo” (KOELLREUTTER, 1997c, p. 134). Vê-se em sua fala, novamente, o destaque para o diálogo, forte ponto de convergência na abordagem de ambos educadores.

Alguns pesquisadores vêm apontando relações entre as propostas de H-J. Koellreutter e Paulo Freire. Brito (2011) afirma que as proposições pedagógicas do primeiro possuem afinidades com o pensamento de alguns pedagogos e filósofos, tais como Paulo Freire.

\footnotetext{
As proposições pedagógicas de Hans-Joachim Koellreutter vão ao encontro do pensamento de pedagogos, cientistas e filósofos contemporâneos que visam à construção de novos paradigmas para a formação e o exercício da cidadania de um ser humano íntegro e integrado - consigo, com o outro, com o meio ambiente. Entre muitos estudiosos, podemos destacar Paulo Freire, Edgar Morin, Ubiritan D’Ambrosio, Howard Gardner e Maria Cândida Moraes, que estão sintonizados, em diversos pontos e aspectos, com as propostas apresentadas por Koellreutter durante as recentes décadas (BRITO, 2011, p. 28).
}

Latorre (2014), em sua tese de doutorado, expõe diversos pontos de convergência entre as propostas destes educadores. Dentre estes, pode-se citar: (1) o professor não é o único detentor de saber - tanto ele quanto os alunos produzem e aprendem saberes; (2) o professor é apenas o mediador no processo de aquisição ou produção de conhecimento; (3) este processo, por sua vez, é dialógico - a educação deve ser uma interatividade dialógica entre professor e alunos; (4) críticas à concepção bancária da educação, por parte de Paulo Freire, e a proposta 
de um ensino pré-figurativo, realizada por Koellreutter; (5) a educação como conscientização; (6) formação humana integral, objetivando cidadãos críticos; etc.

Outro importante fator comum nas proposições destes autores é o estímulo dado à curiosidade, assim como às perguntas que poderão surgir no decorrer das aulas. Para Freire (1996), ensinar exige curiosidade, tanto por parte do educando quanto por parte do educador.

Se há uma prática exemplar como negação da experiência formadora é a que dificulta ou inibe a curiosidade do educando e, em conseqüência, a do educador. É que o educador que, entregue a procedimentos autoritários ou paternalistas que impedem ou dificultam o exercício da curiosidade do educando, termina por igualmente tolher sua própria curiosidade [...] Como professor devo saber que sem a curiosidade que me move, que me inquieta, que me insere na busca, não aprendo nem ensino (FREIRE, 1996, p. 51-52).

Desta forma, o educador propõe que se estimulem as perguntas nos processos pedagógicos, as reflexões críticas acerca dos questionamentos realizados, a curiosidade, a dialogicidade, ao invés da passividade de uma aula em que o professor se mantém em seu discurso narrativo. Haverá espaço para a fala do professor, porém, para Freire (1996), um bom professor é aquele que, enquanto fala, consegue aproximar o aluno de seus pensamentos. “Sua aula é assim um desafio e não uma 'cantiga de ninar'. Seus alunos cansam, não dormem. Cansam porque acompanham as idas e vindas de seu pensamento, surpreendem suas pausas, suas dúvidas, suas incertezas” (FREIRE, 1996, p. 52). O educador orientava a:

Estimular a pergunta, a reflexão crítica sobre a própria pergunta, o que se pode
pretender com esta ou com aquela pergunta em lugar da passividade em face das
explicações discursivas do professor, espécies de respostas a perguntas que não
foram feitas. Isto significa realmente que devamos reduzir a atividade docente em
nome da defesa da curiosidade necessária, a puro vai-e-vem de perguntas e
respostas, que burocraticamente se esterilizam. A dialogicidade não nega a validade
de momentos explicativos, narrativos em que o professor expõe ou fala do objeto. O
fundamental é que o professor e alunos saibam que a postura deles, do professor e
dos alunos, é dialógica, aberta, curiosa, indagadora e não apassivada, enquanto fala
ou enquanto ouve. O que importa é que professor e alunos se assumam
epistemologicamente curiosos (FREIRE, 1996, p. 52).

Este estímulo às perguntas pode ser claramente observado nas proposições de Koellreutter. Dentre os princípios pedagógicos que orientavam sua postura como educador está o do “questionamento constante: POR QUÊ?” (BRITO, 2011, p. 20). Segundo Brito (2011, p. 34), “a dúvida sempre foi a mola mestra do modo de ser e pensar de Koellreutter. Seu constante 'POR QUÊ' é, a um só tempo, 'alfa e ômega, princípio e fim da ciência e da 
arte'.” Portanto, acreditando na importância destes incessantes questionamentos, o professor recomendou diversas vezes:

\begin{abstract}
Não acreditem em nada do que dizem os livros. Não acreditem em nada do que dizem seus professores. Não acreditem em nada do que vocês veem ou mesmo pensam, e também não acreditem em nada do que eu digo. Perguntem sempre por que a tudo e a todos. Tenham uma placa com um "Por quê?” bem grande escrito, em cima da cama, para lembrarem-se de perguntar "por que" logo ao acordar (KOELLREUTTER apud BRITO, 2011, p. 34).
\end{abstract}

Suas orientações aos alunos acerca da importância de um constante questionamento, entretanto, não estavam relacionadas com a procura de respostas exatas, mas sim com o desejo de que os estudantes lidassem com a subjetividade e complexidade, ampliando-se percepções. Logo,

é preciso cuidado para não confundir sua postura e orientação para questionar incessantemente, com a procura de respostas exatas, racionais e objetivas. Seu interesse consistia em ampliar, transformar, repensar, integrar e lidar com a subjetividade e, ao mesmo tempo, com a complexidade inerente a todas as coisas (BRITO, 2011, p. 35).

A postura desse educador revela uma preocupação com a formação de cidadãos críticos. Assim como valorizava os espaços de diálogo e debates, Koellreutter orientava ao questionamento diário, ao levantamento dos “por quês?”. Escrevendo acerca de conteúdos e programas de educação, Koellreutter (1997) sinaliza a problemática de "uma educação que tenda, essencialmente, ao questionamento crítico do sistema e não à sua reprodução, que tenda ao despertar e ao desenvolvimento da criatividade e não à adaptação e à assimilação" (KOELLREUTTER, 1997b, p.55). Não simplesmente reproduzir, mas pensar sobre o sistema; não apenas adaptar ou assimilar, mas questionar: estas são mais algumas ideias e preocupações do educador que convergem não apenas com o pensamento de Paulo Freire, mas com o de outros autores apresentados até então, tal como Silvio Gallo.

Vale ressaltar que, dentre os autores, pesquisadores, educadores e filósofos acerca dos quais discorri até este momento, diversas relações podem ser estabelecidas. Além das já expostas anteriormente, como os conceitos deleuzianos abordados nas obras de Silvio Gallo e Teca Alencar de Brito, e as convergências entre o pensamento freireano e koellreutteriano, são perceptíveis afinidades entre outros autores. Foucault (1999), por exemplo, analisa a escola e sua estrutura comparando-a com a de uma prisão, apontando a intenção de 
disciplinarização e de formação de corpos dóceis. Paulo Freire (1983), por sua vez, expõe a educação bancária, o “opressor” versus “oprimido”, as relações de poder e disciplina nesta concepção e, por fim, a domesticação (disciplinarização) pela educação. Foucault (1999) e Gallo (2014b) versam acerca da avaliação na escola e suas funções de controle/disciplinarização. Koellreutter (1997a) volta-se contra o uso de métodos que, na opinião do educador, limitam e impõem. Gallo (2014b) também ressalta problemáticas acerca dos métodos. Para o autor, assim com a avaliação e outros instrumentos de controle, os métodos são mais uma tentativa de barrar singularidades, de dominar e massificar.

Ainda a respeito de Koellreutter, Brito (2007, p. 63) aponta: “com sua proposta, Koellreutter se aproximou bastante de um pensar rizomático. Era como rizoma que ele pensava na ramificação dos conteúdos, das experiências, dos saberes. Ensinar/aprender era fazer rizomas, ainda que ele não tenha sido, provavelmente, um leitor de Deleuze”. A educadora traçou, portanto, aproximações entre o pensar de Koellreutter e Deleuze, destacando as ideias de ramificação de conteúdos e rizoma ${ }^{5}$. Koellreutter (1997b) julgava a separação de conteúdos como algo bastante contraditório, ainda mais ao considerar a época em que ele vivia. Já na década de 1990 o educador apontava as comprovações da ciência moderna, a ideia de relações entre todas as coisas e a consciência de que nenhuma atividade intelectual pode ser trabalhada isoladamente. Em um “apelo”, Koellreutter (1997b) ${ }^{6}$ se manifesta acerca destas questões:

Alunos desta escola, apelo a vocês: deixem-se levar pela consciência das relações entre as coisas - é que a ciência moderna comprovou que não há objetos ou fatos, mas sim, exclusivamente relações -, deixem-se levar pela consciência destas relações, pela verdade de que nenhuma atividade intelectual pode ser isolada [...] O

\footnotetext{
${ }^{5}$ Rizoma é um termo proveniente da área da botânica que foi deslocado (“roubado”) por Deleuze e Guattari para a área da filosofia. Para estes filósofos, rizoma é um sistema aberto, que não se fecha sobre si, que permite interações e inúmeras relações. O conceito de rizoma é trabalhado também por Gallo (2008). Segundo ele, "a metáfora do rizoma subverte a ordem da metáfora arbórea, tomando como imagem aquele tipo de caule radiciforme de alguns vegetais, formado por uma miríade de pequenas raízes emaranhadas em meio a pequenos bulbos armazenatícios, colocando em questão a relação intrínseca entre as várias áreas do saber, representadas cada uma delas pelas inúmeras linhas fibrosas de um rizoma, que se entrelaçam e se engalfinham formando um conjunto complexo no qual os elementos remetem necessariamente uns aos outros e mesmo para fora do próprio conjunto. Diferente da árvore, a imagem do rizoma não se presta nem a uma hierarquização nem a ser tomada como paradigma, pois nunca há um rizoma, mas rizomas; na mesma medida em que o paradigma, fechado, paralisa o pensamento, o rizoma, sempre aberto, faz proliferar pensamentos” (GALLO, 2008, p.76).

${ }^{6}$ Embora publicado no ano de 1997, este artigo foi lido em aulas inaugurais da Escola de Música da UFMG e da Faculdade Santa Marcelina no ano de 1984.
} 
espírito criador não permite - hoje menos que nunca - que os vários ramos da educação artística sejam ensinados independentemente, uns dos outros, sem relações (KOELLREUTTER, 1997b, p. 54-55).

Outras relações entre os autores citados até então podem ser traçadas. Coube aqui apontar algumas destas, sem maiores aprofundamentos, tendo em vista os limites deste trabalho, os objetivos do mesmo e, além disso, o espaço para questões que ainda precisam ser tratadas. Vale ressaltar que, mesmo com as inúmeras contribuições destes e de outros autores, permanecemos em um sistema cujo modelo escolar está voltado para interesses maiores; mantém uma divisão entre professor (aquele que explica, sabe, narra...) e aluno (aquele que ouve e aprende - supostamente); permanece com sistemas de avaliação e controle (e, cada vez mais, ergue os ideais das "boas notas”, do "passar no vestibular”, estimula as competições, etc.); divide/fragmenta os saberes no que permanece intitulando de “disciplinas”; conserva o seu “mapa estratégico”, como mencionou Gallo (1995), dispondo suas carteiras em filas, o quadro-negro à frente, etc.

\begin{abstract}
As tecnologias individualizantes utilizadas na escola, que nos parecem muito naturais, são na verdade bastante recentes: uma das mais simples e eficazes é a disposição estratégica da classe em filas. Essa disposição permite que todos os alunos sejam vigiados e controlados constantemente por um único professor. Tais tecnologias atingem os indivíduos em seus próprios corpos e comportamentos, constituindo-se numa verdadeira "anatomia política”, que individualiza a relação de poder. Essas estratégias de dominação, através da delimitação de espaços e da disciplina corporal, diferem quase nada em sua aplicação, seja nos exércitos seja nas escolas (GALLO, 2004, p. 92).
\end{abstract}

Ao observarmos que a escola conserva hábitos tão criticados no decorrer do tempo, podemos retornar à ideia de descompasso apresentada no início deste trabalho. Um descompasso com os novos pensamentos, proposições e ideias desenvolvidas por diversos pesquisadores nas últimas décadas (em contrapartida, uma escola "bastante atual” e "dentro do compasso” considerando, como já expôs Bittencourt (2007), seus propósitos biopolíticos de controle e disciplinarização).

Antes de concluir esta primeira parte do texto, mais uma autora pode ser citada, tendo em vista suas contribuições para a área da educação e, mais especificamente, da educação musical. Por meio de seus apontamentos e de seus “diagnósticos”, pode-se retomar as questões apresentadas no início deste trabalho: a ideia do constante movimento inerente à atualidade e, todavia, a do descompasso na área da educação. 
Marisa Trench Fonterrada (1939-), educadora musical e pesquisadora, ergueu reflexões a respeito da maneira atual de nos aproximarmos do conhecimento e recebermos a informação. Na obra De Tramas e Fios: um ensaio sobre música e educação, a autora versa acerca das

modificações que vêm ocorrendo no mundo atual e da necessidade de a educação, de modo geral, e a educação musical, em particular, adaptar-se a elas, buscando modos de ação alternativos, em substituição aos tradicionalmente empregados, incapazes, em muitos aspectos, de responder aos novos desafios (FONTERRADA, 2008, p. 15).

Fonterrada (2008) destina parte de seu trabalho para tratar dos procedimentos em linha e em rede. Segundo ela, esta discussão não é gratuita, "amparando-se em necessidades reais de determinados segmentos da sociedade, constituindo-se em desafios que obrigam a busca por novos procedimentos, pois os comumente adotados na prática educativa já não atendem a esse tipo de demanda” (FONTERRADA, 2008, p. 16). A pesquisadora reconhece que as áreas da música e da educação musical são afetadas por este contínuo movimento, por estes processos de modificação, salientando, entretanto, o descompasso, as fissuras e as brechas existentes nestes campos, considerando que estamos defronte novas condições, insistindo, ainda, em condutas que já não respondem às novas questões.

Os campos da música e da educação musical são, também, afetados por esse estado de coisas, e as alterações que se apresentam a cada dia tornam difícil encontrar caminhos estáveis e adequados. Há evidentes sinais de fissuras que, rapidamente, tornam-se brechas e criam vales quase intransponíveis. Diante das novas condições, condutas costumeiramente adotadas para responder a determinadas questões já não conseguem dar conta delas (FONTERRADA, 2008, p. 280).

Retomo, portanto, para esta necessidade apontada por diversos autores: necessidade de modificações na educação, de meios alternativos para os processos de ensino e aprendizagem, de uma busca por novos procedimentos - ao invés da insistência em métodos e caminhos já aplicados e que, atualmente, não cabem mais, não correspondem às novas problemáticas. É necessária uma abertura ao novo, correndo-se os riscos de tal ato (GALLO, 2014b).

Como segurança, visando a segurança, buscando a segurança, as escolas matam a criatividade, acabam com a vida, pois abrir-se ao novo é arriscar-se sempre na corda bamba, à beira do abismo, sem nenhuma rede de proteção. É preciso abrir-se ao possível, ao ainda não, ao impensado e ao impensável, e tudo isso é arriscado. Os métodos, as avaliações, os variados instrumentos de controle, são tentativas de 
conter as diferenças, barrar as singularidades, massificar, dominar. Mas, felizmente, a vida escapa, a vida é uma multiplicidade de linhas de fuga, e há aqueles que conseguem singularizar. O investimento numa "pedagogia do risco", numa "filosofia da diferença”, vai na direção de potencializar e multiplicar essas linhas de fuga. Fazer com que as diferenças e as singularidades vazem por todos os poros (GALLO, 2014b, s/p).

Apesar de detectados e reconhecidos tais mecanismos de controle ao longo do tempo, a escola mantém sua estrutura. Entretanto, embora vivenciemos um modelo de escola que já não cabe em nosso tempo, gerando este grande descompasso, as contribuições dos educadores e/ou filósofos citados (além de muitos outros não mencionados neste trabalho) permitiram realizar um “diagnóstico”, uma análise da estrutura escolar e dos processos de ensino e aprendizagem. A partir de suas intervenções, estes autores colaboraram para que muitos educadores pudessem repensar práticas pedagógicas e formular, cada um, suas linhas de fugas... Afinal, como aponta Bittencourt (2007, p. 33), “apesar do quadro negativo que vem sendo apontado, a escola, entre essas instituições [exército, escola, fábrica, prisão], é a única com potencial para transformar toda uma sociedade”.

Ciente das dificuldades impostas por este grande sistema, porém, reconhecendo sobremaneira a importância de repensarmos a educação e de afirmarmos nossas linhas de fuga, abarcarei reflexões acerca do processo pedagógico da música por meio do jogo e da improvisação musical. A proposta de valer-se do ambiente do jogo, além da criação/improvisação musical, surge na tentativa de superar ou, ao menos, reduzir este descompasso entre as proposições pedagógicas atuais e as efetivas práticas na sala de aula ponderando que, apesar das muitas pesquisas que demonstram o ambiente lúdico como um espaço de formação propício às descobertas, às invenções, ao desenvolvimento da criatividade e aberto às manifestações expressivas dos estudantes, além dos trabalhos que enfatizam a importância da criação na educação musical, as aulas de música nas escolas não têm sido, comumente, ambientes para vivências de jogos e criações musicais coletivas. Em muitos contextos,

continuamos apenas cantando canções que já vêm prontas, tocando os instrumentos única e exclusivamente de acordo com as indicações prévias do professor, batendo o pulso, o ritmo, etc., quase sempre excluindo a interação com a linguagem musical, que se dá pela exploração, pela pesquisa e criação, pela integração de subjetivo e objetivo, de sujeito e objeto, pela elaboração de hipóteses e comparação de possibilidades, pela ampliação de recursos, respeitando as experiências prévias, a maturidade, a cultura do aluno, seus interesses e sua motivação interna e externa (BRITO, 2003, p. 52). 
Observando a educação musical com crianças e as concepções que, atualmente, permeiam práticas pedagógicas com as mesmas, percebem-se reflexos de modelos já estabilizados. O jogo do criar permanece, muitas vezes, distante da formação musical de crianças. Portanto, é necessária a compreensão de que

\begin{abstract}
fazer música pode ser bem mais do que aprender a reproduzir tons e ritmos; do que desenvolver a disciplina necessária à boa repetição de modelos estabilizados. Fazer música com as crianças pode ser jogo que mergulha no caos de onde emergem as forças do sensível; jogo que é presente e forte no modo de ser e viver da criança, mas que, não raro, fica distante dos ambientes destinados à sua formação, à sua educação (BRITO, 2007, p.11).
\end{abstract}

Desta forma, busquei destacar o jogo e a criação como alternativas para os processos de ensino e aprendizagem da música. O jogo como ambiente para o aprender brincando, para a diversão e conhecimento de si, para a interação entre os participantes, o diálogo, debates, a autonomia, a liberdade e, pensando ainda em outras questões, como espaço para estar em roda, caminhar, correr, trocar de lugar, ocupar a sala de diferentes maneiras, ao invés da repetição do já citado "mapa estratégico” - com alunos em suas carteiras, dispostos em filas, etc.

A ideia da criação, por conseguinte, considerando a relação intrínseca entre a arte e o criar. Segundo Koellreutter (1997a, p. 31), “não há normas, nem fórmulas, nem regras que possam salvar uma obra de arte, na qual não vive o poder de invenção”. Ao mesmo tempo, tal ideia visa enfatizar a importância de espaços para a criação na formação musical de crianças, de ambientes que proporcionem aos alunos momentos para a exploração sonora, para as improvisações coletivas, para a criação de suas próprias músicas (juntamente à tomada de decisões, escolhas, autonomia no decorrer dos processos de criação), além de possibilitar que se expressem por meio de suas próprias obras - e não apenas pela interpretação do discurso de terceiros. Ou seja: um espaço (território) que atente para o modo menor musical da criança, ouvindo-a, abarcando suas ideias de música, trabalhando não apenas com os "planos funcionais de ensino musical movidos pelo preparar para operar; para uma espécie de realização musical pré-fabricada, mas sim, os planos de composição que permitem e favorecem o acontecimento, a criação de devires, de alianças, de ritornelos” (BRITO, 2007, p. 2). 
Assim sendo, darei prosseguimento a este trabalho discorrendo, nos próximos tópicos, a respeito da importância do jogo na educação e dos processos de criação - especificamente a improvisação - na educação musical.

\title{
1.1 O JOGO
}

O jogo é inerente ao ser humano (HUIZINGA, 2012). Jogamos em nosso dia-a-dia.

\begin{abstract}
Enquanto crianças, manipulamos a realidade nas brincadeiras de faz-de-conta e em nossa imaginação. Ao crescermos, permanecemos jogando, seja através dos esportes, dos games, tanto em jogos de competição quanto em cooperativos, ou até mesmo nos papeis sociais que performamos nas mais diversas situações (ZANETTA, 2012, p. 14).
\end{abstract}

O ser humano sempre jogou. Para o professor, historiador e filósofo holandês Johan Huizinga (1872-1945), “é no jogo e pelo jogo que a civilização surge e se desenvolve” (HUIZINGA, 2012, prefácio). Esta, dentre outras concepções acerca das relações entre jogo, civilização humana e cultura, são desenvolvidas pelo autor na obra Homo Ludens, livro datado de 1938.

Estudando a natureza e o significado do jogo como fenômeno cultural, Huizinga (2012) parte do ponto de vista de que o jogo faz-se anterior à cultura, sendo categoria primária de vida, presente desde o nível animal. O historiador relata que os animais, assim como os homens, experimentam o divertimento que há no brincar.

O jogo é fato mais antigo que a cultura, pois esta, mesmo em suas definições menos rigorosas, pressupõe sempre a sociedade humana; mas, os animais não esperaram que os homens os iniciassem na atividade lúdica. É-nos possível afirmar com segurança que a civilização humana não acrescentou característica essencial alguma à ideia geral de jogo. Os animais brincam tal como os homens. Bastará que observemos os cachorrinhos para constatar que, em suas alegres evoluções, encontram-se presentes todos os elementos essenciais do jogo humano. Convidamse uns aos outros para brincar mediante um certo ritual de atitudes e gestos. Fingem ficar zangados e, o que é mais importante, eles, em tudo isto, experimentam evidentemente imenso prazer e divertimento (HUIZINGA, 2012, p. 3). 
Outras questões são trabalhadas pelo autor no decorrer de sua obra, tais como (1) a relação entre as esferas do jogo e do sagrado - versando a respeito dos mitos, dos ritos, dos cultos e celebrações sagradas; (2) a problemática na definição do termo jogo - refletindo acerca dos limites de significação deste termo, tendo em vista as diferentes línguas e as diversas palavras existentes para exprimir tal conceito (3) e as características do jogo considerando que, apesar de não ser passível de uma definição exata, as características/propriedades deste contexto lúdico podem ser levantadas. A seguir, darei ênfase a esta última questão, uma vez que o interesse desta pesquisa está em analisar as diversas características do jogo com vias a compreender sua importância nos contextos pedagógicos.

Torna-se importante salientar que o jogo, como objeto de estudo de diferentes pesquisadores, tem recebido, igualmente, diferentes definições. Erguem-se teorias acerca de seu surgimento, busca-se determinar sua natureza e seu significado, tratam de conceituá-lo, analisar seus objetivos e o porquê de jogarmos. Apesar de serem diversas as hipóteses e definições levantadas, em geral, como apontou Huizinga (2012), elas não divergem entre si, mas se complementam.

Todas elas [hipóteses] se interrogam sobre o porquê e os objetivos do jogo. As diversas respostas tendem mais a completar-se do que a excluir-se mutuamente. Seria perfeitamente possível aceitar quase todas sem que isso resultasse numa grande confusão de pensamento, mas nem por isso nos aproximaríamos de uma verdadeira compreensão do conceito de jogo (HUIZINGA, 2012, p. 4).

Ainda que as diversas respostas fossem consideradas, buscando-se um melhor entendimento do fenômeno em questão, o autor acredita que não nos aproximaríamos de uma verdadeira compreensão acerca do conceito de jogo.

Sabe-se da dificuldade em definir o termo jogo tanto pela sua variação em outras línguas - que causam alterações em sua compreensão, tendo em vista que cada contexto cria um termo baseado em sua concepção de jogo - quanto pela ampla gama de jogos que conhecemos e que, para alguns, são nomeados de "brincadeiras”, "brinquedos”, dentre outros termos. Como relata Kishimoto (1994, p. 105-106) “tentar definir o jogo não é tarefa fácil. Quando se diz a palavra jogo cada um pode entendê-la de modo diferente [...] a dificuldade aumenta quando se percebe que um mesmo comportamento pode ser visto como jogo ou nãojogo”. Lombardi (2005, p. 72-73) acredita que "não há como estabelecer uma definição única 
e essencial do que é jogo, nem limitar este fenômeno”. Huizinga (2012, p. 10) também apresenta tal problemática, expondo que “o jogo é uma função da vida, mas não é passível de definição exata em termos lógicos, biológicos ou estéticos. [...] Teremos, portanto, de limitarnos a descrever suas principais características”.

Por conseguinte, reconhecendo a complexidade deste fenômeno e, principalmente, o interesse e recorte desta pesquisa, este trabalho seguirá apontando as principais características do jogo.

\subsection{CARACTERÍSTICAS DO JOGO}

Para Huizinga (2012) o jogo é uma atividade livre, voluntária, consistindo em uma evasão da “vida real”, em um mundo temporário dentro do mundo habitual. É constituído de regras e limitado em tempo e espaço. O seu ar de mistério, imaginação, encanto, arrebatamento, incertezas, tensão, possibilita uma separação entre os que estão em jogo e os que estão "lá fora”. Ainda segundo o autor, o jogo fixa-se como fenômeno cultural. Estas são algumas das características apresentadas pelo filósofo ao longo de seu livro. Arriscando uma síntese, ele descreve:

\footnotetext{
Numa tentativa de resumir as características formais do jogo, poderíamos considerálo uma atividade livre, conscientemente tomada como "não-séria" e exterior à vida habitual, mas ao mesmo tempo capaz de absorver o jogador de maneira intensa e total. É uma atividade desligada de todo e qualquer interesse material, com a qual não se pode obter qualquer lucro, praticada dentro de limites espaciais e temporais próprios, segundo uma certa ordem e certas regras. Promove a formação de grupos sociais com tendência a rodearem-se de segredo e a sublinharem sua diferença em relação ao resto do mundo por meio de disfarces ou outros meios semelhantes (HUIZINGA, 2012, p. 16).
}

O professor e filósofo francês Gilles Brougère (1955-) também discorre acerca do lúdico e do jogo em alguns de seus livros, tais como Brinquedo e cultura (1995) e Jogo e educação (1998). Para este autor, não existe diferença entre jogo e brincadeira. Ele relata: “contrapor brincadeira e jogo, coisa que os franceses não podem fazer, pois para nós há uma única palavra para designar brincadeira e jogo - jeu -, é desconhecer as diferentes dimensões 
de um fenômeno social” (BROUGÈRE, 2012, s/p). Portanto, quando aborda questões a respeito da brincadeira, o filósofo está abarcando o jogo, e vice-versa.

Em sua concepção, o jogo é uma construção social e cabe tanto ao adulto quanto à criança. Ainda de acordo com Brougère (1998), o jogo constitui-se em uma ação regrada, cujas regras podem ser preexistentes ou construídas no decorrer do trabalho. Um acordo mútuo entre os jogadores permite a transformação das regras que, por sua vez, terão validade caso aceitas por todos os participantes e apenas durante o desencadear do jogo.

A incerteza é outro critério que Brougère (1998) estabelece para reconhecermos uma determinada situação como jogo. O pesquisador destaca que, neste contexto lúdico, os participantes agem sem saber previamente o que acontecerá no decorrer da ação. Além disso, acredita que para existir jogo deve haver a possibilidade de decisões, de escolhas. Deste modo, os jogadores devem optar por participar ou não do jogo, organizá-lo e, no transcurso do mesmo, caso desejem, transformá-lo. Assim sendo, deve haver o que Brougère (1998, p. 191) nomeia de "possibilidade real de decidir”.

[...] para que essa situação particular se crie, há uma decisão da parte dos jogadores: decisão de entrar no jogo, mas também de organizá-lo de acordo com modalidades particulares. Sem livre escolha, isto é, possibilidade real de decidir, não há mais jogo, e sim sucessão de comportamentos que tem sua origem fora do jogador. Se um jogador de xadrez não é livre para decidir sua próxima jogada, não é mais ele quem joga. [...] O jogo surge então como um sistema de sucessões de decisões (BROUGÈRE, 1998, p. 191).

Outra concepção de jogo e de suas características que vale ressaltar é a de Deleuze (2006). O filósofo propõe uma abordagem acerca do que intitula jogo ideal: um jogo sem regras preexistentes - podendo estas ser construídas durante o próprio ato de jogar - e sem ganhadores ou perdedores. Segundo o autor, consiste em um jogo "reservado ao pensamento e à arte, lá onde não há vitórias para aqueles que souberem jogar, isto é, afirmar e ramificar o acaso, ao invés de dividi-lo para dominá-lo, para apostar, para ganhar” (DELEUZE, 2006, p. 63). Brito (2007) também abarca questões a respeito do jogo ideal em seu trabalho. A autora comenta:

Gilles Deleuze propôs que se busque o jogo ideal, o jogo em estado puro, que não conta com regras preexistentes; nele, o conjunto das jogadas afirma todo o acaso e não cessa de ramifica-lo em cada jogada; jogo no qual as jogadas são apenas qualitativamente distintas (DELEUZE, 1997). As regras se constroem ao jogar, como o "caminho se traça ao caminhar". O jogo ideal a que se refere Deleuze é o 
jogo do pensamento [...] Assim sendo, consideramos como ideais o jogo da música, bem como o jogo da criança, para quem o jogar, o brincar em si mesmo, é modo de vida que vem e vai, que flui sem vencedores ou perdedores, que é jeito de perceber, de sentir, de viver (BRITO, 2007, p. 44).

Alguns pesquisadores da área da música têm, inclusive, compreendido a prática da livre improvisação como uma aproximação do conceito de jogo ideal. Dentre estes, pode-se destacar os trabalhos de Rogério Luiz Moraes Costa (2003, 2012), autor que vem abrangendo uma pesquisa sobre livre improvisação apoiada na filosofia de Gilles Deleuze e Félix Guattari.

Existem ainda diversas outras abordagens/concepções acerca do jogo e de suas características. Muitas delas resultam de pesquisas realizadas por educadores que, acreditando no potencial do jogo nos processos pedagógicos, discorrem acerca do tema. Considerando que refletir a respeito do jogo na educação é interesse também desta pesquisa, seguirei apontando as opiniões e reflexões de profissionais da área da educação.

\subsection{O JOGO NOS PROCESSOS DE ENSINO E APRENDIZAGEM}

A inserção e a importância do jogo na educação vêm sendo pesquisadas por vários estudiosos, tais como Brougère (1998, 2002), Kishimoto (1993, 1996, 1998), Lima (2008), Luckesi (2000, 2002) e Pereira (2004).

Brougère (2002) analisa as relações entre jogo e educação, expondo contradições entre o “jogo educativo” e o jogo com fim em si mesmo (que pode ser vivenciado nas salas de aula, desde que mantenha seus critérios/características de jogo); entre as atividades mais estruturadas, de cunho escolar, que recebem uma dimensão lúdica, e o jogo da criança que, em parte, continua a escapar da lógica adulta. O autor propõe que se pense o jogo para, após, pensar seu potencial educativo - lembrando que, para Brougère (2002, p. 14) "não é a situação enquanto tal que é secundariamente educativa, é a experiência que o indivíduo vivencia que pode ter o efeito educativo”.

Brougère (2002) também faz comparações entre a ação educativa formal e quatro critérios presentes no jogo (regra, decisão, frivolidade e incerteza), destacando convergências e divergências. Para ele, as ações pedagógicas comportam regras, assim como o jogo. Já o 
critério de decisão, na opinião do autor, converge com visões mais contemporâneas de educação que assinalam a importância da iniciativa do aluno, mas diverge da educação concebida tradicionalmente, cuja decisão cabe ao professor. Por fim, ressalta que as características de "frivolidade e incerteza parecem antagônicas com um projeto educativo e uma educação que perseguem objetivos de aprendizagem” (BROUGÈRE, 2002, p. 11). A partir destes dois últimos critérios, o filósofo demonstra uma tensão entre jogo e educação, afinal, "como uma atividade frívola, distante de todo objetivo de aprendizagem, pode manter uma relação com um processo educativo?” (BROUGÈRE, 2002, p. 11). Pensando-se o jogo não de forma isolada, mas no conjunto de uma pluralidade de atividades, o autor discorre acerca desta problemática.

Brougère (2012) trabalha conceituações da educação informal, em que a criança "aprende através de situações da vida cotidiana que nada têm a priori de educativas: conversações, passeios, televisão e espetáculos, refeições e atividades da vida cotidiana” (BROUGÈRE, 2002, p. 12). Cita, ainda, o modo como a criança aprende a falar em situações lúdicas que a mãe desenvolve, por exemplo, durante o banho: “os objetivos são da ordem do prazer ou da gestão do tempo do banho, mas atingem outros efeitos e co-produzem aprendizagem que não é ativamente buscada pela atividade do banhar” (BROUGÈRE, 2002, p. 13). O professor então apresenta o que, a seu ver, constitui o paradoxo da educação: a ideia de que "uma situação educativa pode não produzir efeito educativo algum, e uma situação ‘comum' pode ter efeitos educativos” (BROUGÈRE, 2002, p. 14).

Através da noção de educação informal, este filósofo pensa a relação entre jogo e educação. Trata-se de compreender que o jogador busca pelo divertimento, pelo prazer. Porém, no ato de jogar, ele pode vivenciar uma experiência de aprendizagem, demonstrandose, então, o potencial educativo do jogo. Com isso, Brougère (2002, p. 14) destaca que "a dimensão educativa não é própria do jogo e deve ser pensada de maneira mais geral [...] o jogo não é uma atividade ou uma situação educativa, mas ele pode gerar uma experiência que tenha efeitos educativos.” O autor explica:

O jogo, como qualquer atividade da vida, com diversas características conjuntas com o lazer, pode ser considerado como uma experiência polimorfa. Se ele é almejado pelo prazer que usufrui, isso não significa que outros efeitos não lhe possam ser incorporados. A experiência assim construída e vivida pode possibilitar o encontro de aprendizagens (BROUGÈRE, 2002, p. 18-19). 
Por meio destas reflexões, o professor enfatiza a importância de conhecermos mais o ato de aprender, mesmo quando este ocorre no dia-a-dia em momentos em que não se está procurando pelo aprendizado. Ele afirma: “quando soubermos mais sobre como se aprende, mesmo sem procurar aprender, nas múltiplas experiências da vida cotidiana, poderemos passar do mito à realidade do potencial educativo do jogo” (BROUGÈRE, 2002, p. 19).

O professor José Milton de Lima também trabalha com a temática do jogo e suas relações com a educação, estabelecendo elos com o pensamento de Gilles Brougère. Na obra “O jogo como recurso pedagógico no contexto educacional”, Lima (2008) aponta a falsa dicotomia existente entre o jogar e o aprender. Segundo o autor, a existência desta dicotomia acarreta na secundarização e depreciação do jogo como recurso pedagógico: este contexto lúdico passa a ser tratado como prescindível pelas instituições educacionais ou passa a ser utilizado como meio para relaxamento e descanso das crianças.

Apesar de a aprendizagem e o jogo serem atividades de naturezas diferentes, defendemos que elas podem ser utilizadas de forma complementar, colaborando na superação da falsa dicotomia que se instalou na escola, onde o jogar e o aprender são atividades não conciliáveis. Essa tendência predominante, que dicotomiza o jogar e o aprender, trata os momentos de aprendizagem com uma "certa seriedade” e os torna diretivos, na maioria das vezes; as atividades lúdicas são tomadas como momentos de descarga de energia excedente, de recreio, de descontração e acontecem, com frequência, quando não se tem mais nada para fazer (LIMA, 2008, p. 27).

O autor chama a atenção para o fato de Brougère (1998) defender que "é possível a conciliação entre o jogar e o aprender, no contexto educacional, desde que sejam respeitadas as características do jogo como atividade espontânea, não produtiva e incerta” (LIMA, 2008, p. 18). Logo, podem-se retomar as questões levantadas por Brougère (2012) acerca dos critérios do jogo e da importância destes se manterem, ainda que em sala de aula - de maneira que não se descaracterize este contexto lúdico. Lima (2008) ressalta, ainda, a importância de o educador adquirir conhecimento a respeito do jogo e de compreender seu valor no contexto educacional.

Quanto mais o educador conhecer sobre esse tipo de atividade, mais ele pode compreender o que acontece no interior do jogo, permitindo-lhe certa interferência e influência. A compreensão do jogo na sua essência, a elucidação da sua importância no contexto educacional e as possibilidades de interferência são pólos que se interpenetram e se complementam, oferecendo subsídios para a incorporação do jogo como recurso pedagógico (LIMA, 2008, p. 20). 
Tratando das tendências atuais acerca do jogo na educação, Lima (2008) cita, dentre outras, (1) a denominada "ausência e proibição da brincadeira”, (2) a que pensa o jogo como “instrumento didático", (3) e a que compreende o jogo como “atividade recreativa”. Segundo Lima (2008, p. 25-26), na primeira tendência “o jogo é tratado como obstáculo para a aprendizagem, pois desconcentra e dispersa a criança [...] permeia o medo de que tais atividades comprometam o ensinar e acentuem nas crianças a preguiça e a negligência”. Por sua vez, a segunda tendência concebe o jogo como meio para domínio de conteúdos, espaço em que os "objetivos instrucionais" têm prioridade. Trata-se, portanto, de compreender este contexto lúdico como

um meio preparatório para a aprendizagem e domínio de conteúdos escolares das diferentes áreas. A intervenção do educador é direta e sua meta é desenvolver nas crianças habilidades escolares específicas e noções previamente definidas, preparatórias para aprendizagens de conteúdos (LIMA, 2008, p. 26).

Nessa perspectiva, com os “objetivos instrucionais” sendo priorizados, “as contribuições mais significativas do brincar acabam secundarizadas” (LIMA, 2008, p. 26). A terceira visão, por conseguinte, pensa o jogo como espaço para o relaxamento e descanso das crianças, preparando-as física e psicologicamente para as "atividades sérias” que virão na sequência.

\footnotetext{
Uma outra vertente presente no contexto educacional interpreta o jogo como "Atividade recreativa”, isto é, ocasião que permite o relaxamento, o gasto do excesso de energia que ficou acumulada, em razão das atividades passivas desenvolvidas na sala de aula. Os jogos e as brincadeiras servem de momentos de descanso das atividades sérias, um meio de recuperação física e psicológica, preparando as crianças para novas etapas do trabalho escolar (LIMA, 2008, p. 28).
}

Acreditando na importância da presença do jogo no contexto escolar (ao invés do receio e ausência de sua vivência na escola, como aponta a primeira tendência), e pensando também o valor intrínseco do mesmo (não reduzindo o ato de jogar aos objetivos instrucionais/domínios de conteúdos ou às atividades recreativas), uma quarta tendência pode ser apontada: a que vem estudando o jogo como recurso pedagógico. Nesta perspectiva, compreende-se o valor do jogo na sala de aula, sendo este um recurso de formação do ser humano que deve estar presente nos espaços pedagógicos. Vale ressaltar que nesta visão, ao se pensar o jogo como recurso pedagógico, faz-se menção à importância de sua vivência nos 
contextos educacionais, à necessidade do jogo se fazer presente nas salas de aula, e não a uma sujeição/redução do jogo como instrumento de transmissão de conteúdos. Assim sendo, entende-se este espaço lúdico como recurso pedagógico à medida que ele pode ser vivenciado, em sua plenitude, nas salas de aula, e não no sentido de valer-se do mesmo apenas para tornar mais atraente os conteúdos a serem trabalhados.

Esta última abordagem apresentada percebe o jogo infantil e o momento de brincar, por exemplo, como um laboratório, um espaço em que a criança poderá experimentar livremente, pensar, arriscar opções, tomar decisões e construir sua autonomia. Além disso, torna-se um espaço de interação, comunicação, trocas, em que relações sociais podem ser ampliadas, assim como a consciência de si e do mundo.

\begin{abstract}
O momento de brincar pode ser visto como um laboratório, um espaço de experimentação, no qual a criança pode ensaiar, errar, sem a pressão do mundo adulto. A criança, por meio da linguagem simbólica, utiliza-se de objetos, insere-se no mundo da cultura, constrói seu pensamento, lida com seus sentimentos e amplia suas relações sociais. Considerando as especificidades afetivas, emocionais, sociais e cognitivas das crianças da Educação Infantil e das séries iniciais do Ensino Fundamental, as experiências oferecidas em forma de brincadeiras podem ser um privilegiado recurso para a formação da cidadania, para o desenvolvimento psicológico e da personalidade da criança e, também, como forma particular de expressão, interação e comunicação (LIMA, 2008, p. 29-30).
\end{abstract}

Lima (2008) aponta para além da necessidade das crianças brincarem, destacando que este é um direito das mesmas e que, no Brasil, este direito é assegurado por instrumentos legais. Enfatiza também o surgimento de associações internacionais, tais como o IPA (Associação Internacional pelo Direito de Brincar) que, preocupadas com a redução dos espaços para o brincar, objetivam defender e garantir tal direito à criança. Para o IPA, não valorizar o brincar significa

não preparar adequadamente as crianças para enfrentarem com êxito uma sociedade em constantes mudanças e que exige um novo perfil de homem: cooperativo, criativo, dinâmico, versátil, comprometido com uma forma de vida mais humana, menos exclusiva e mais justa (LIMA, 2008, p. 31).

A partir de uma compreensão do brincar como necessidade e direito da criança, Lima (2008) ressalta também outras problemáticas. Dentre estas, salienta que apesar dos avanços científicos e de pesquisas que apontam para a importância do brincar, "vem aumentando significativamente a indiferença e a descrença dos adultos nessas atividades” (LIMA, 2008, p. 
30). O autor comenta que, em uma sociedade capitalista, há valores predominantes em relação ao lúdico. Neste contexto, as crianças são tratadas como um "projeto de adulto", sobrecarregadas com tarefas e obrigações sociais. Acreditando na necessidade da criança cumprir tais deveres, os pais e as escolas negam as atividades lúdicas, temendo uma "perda de tempo” por meio destas (LIMA, 2008, p. 31). Para além, Lima (2008) salienta que alguns pais, no desejo de "ganhar tempo", procuram antecipar etapas das crianças na vida escolar. Este ato acarreta em sobrecarga de atividades às crianças, redução do tempo que elas destinam ao brincar e, consequentemente, na ausência de um espaço essencial para o desenvolvimento de capacidades humanas.

\begin{abstract}
Observa-se nas instituições, principalmente de Educação Infantil, uma pressa, uma preocupação exacerbada em antecipar o processo de escolarização. Alguns pais chegam mesmo a fazer ingressar o filho, de idade inferior, em classe com grupos de crianças mais velhas, acreditando que estão ganhando tempo na formação da criança. A sobrecarga de trabalhos escolares, impostos aos alunos, principalmente na etapa final da Educação Infantil, reduz e não resguarda o tempo para o lúdico, posição esta que priva a criança de um meio significativo e essencial para o desenvolvimento das suas faculdades humanas (LIMA, 2008, p. 30).
\end{abstract}

Destarte, Lima (2008) considera o jogo um valioso recurso pedagógico, à medida que fornece um espaço para o exercício da imaginação, da criação, do pensamento, para uma construção da autonomia e do desenvolvimento de faculdades humanas.

A professora Lucia Helena Pena Pereira também aponta as práticas lúdicas como recursos pedagógicos. Com diversos trabalhos que versam acerca desta temática, a autora compreende a ludicidade como meio para a expansão da consciência e para o desenvolvimento do ser humano, convergindo com o pensamento de outros pesquisadores, tais como Luckesi (2002).

Estabelecendo relações teóricas com a psicologia transpessoal, com a neurobiologia e com a física quântica, Pereira (2004) traça considerações a respeito do modo como se constitui a escola tradicional (destacando que, apesar da física quântica já ter demonstrado a interconexão de tudo com tudo, a educação permanece com uma visão fragmentada), das três estruturas neurais existentes no cérebro humano (abarcando a necessidade de vivências na escola que possibilitem trabalhar a unicidade deste cérebro triparte) e, por fim, das atividades lúdicas como permissivas a uma expansão da consciência, à medida que acessamos estados de consciência para além do ego, alcançando uma região em que o controle cede lugar à entrega. 
As atividades lúdicas, segundo a autora, permitem que "vivenciemos com inteireza um tempo-espaço próprio, que estejamos plenos na experiência, nos entregando a ela sem julgamentos, sem coerções, sem imposições e direcionamentos controladores, com abertura para novas possibilidades” (PEREIRA, 2004, p. 82-83). Valendo-se de estudos acerca da experiência plena, Pereira (2004) afirma:

\begin{abstract}
A ludicidade nos permite flexibilizar o comando do racional e, ao mesmo tempo, expandir nossas consciência para uma dimensão que, usualmente, no cotidiano, não acessamos. São momentos em que, nos livrando das defesas do ego, tão exigente e "estruturado", nos envolvemos com o que fazemos e nos deixamos absorver por este fazer, nos integrando ao grupo, nos conectando com nossa emoção e deixando que o movimento flua, mobilizando nossa energia, gerando uma nova vibração interna. São momentos em que pensamento, sentimento e ação se integram, possibilitando a inteireza do ser humano e a expansão de sua consciência (PEREIRA, 2004, p. 83).
\end{abstract}

A autora também apresenta estudos da neurobiologia que versam acerca de três estruturas neurais do cérebro humano (um sistema tripartite): o cérebro reptiliano, o límbico e o neocórtex. Elas estão relacionadas, respectivamente, à ação (sistema motor, processos físicos), ao sentimento (ligado à manifestação de felicidade/tristeza, por exemplo) e ao pensamento (raciocínio criativo, intelecto). As três estruturas, apesar de possuírem funções próprias, funcionam de forma integrada (PEREIRA, 2004, p. 88).

Pesquisas na área da educação têm levado em conta tal estudo, considerando este sistema tripartite, o fato destas estruturas funcionarem de maneira integrada e a necessidade, portanto, de estímulos para o desenvolvimento de todas as partes. Segundo Pereira (2004, p. 87), “é o desenvolvimento de todos que possibilita que seu potencial seja bem aproveitado". A autora ergue tais reflexões justamente para estabelecer elos com a educação, demonstrando a presença da dicotomia (consequência de uma visão mecanicista) na educação escolar.

Há que se contar, porém, com estímulos para o desenvolvimento dos três sistemas cerebrais. Se os modelos científicos continuarem a aceitar como válido somente o domínio físico, como ainda se verifica com frequência, esses estímulos continuarão a ser negados e não se estabelecerão ambientes apropriados para uma nova visão de mundo e do eu [...] É importante pontuar que esta dicotomia racional/emocional, intelecto/inteligência está presente na educação escolar (PEREIRA, 2004, p. 88-89).

Citando trabalhos de Antonio Damásio (1996) e Humberto Maturana (2001), além de estudos de Joseph Chilton Pearce (2002) e Daniel Goleman (1995), a autora aponta para a ideia de corpo e mente como uma totalidade, da essencial complementaridade entre o sensível 
e o racional, destacando as problemáticas existentes quando não consideramos esta totalidade na educação. Além destas ideias, reflete acerca da intuição como uma inteligência que não vem sendo valorizada. A partir destas questões, a autora aponta as atividades lúdicas como um recurso pedagógico, tendo em vista que agregam ação, sentimento e pensamento (integrando, portanto, as três estruturas cerebrais) e propiciam condições para a intuição se manifestar, permitindo uma expansão da consciência.

Considerar essas questões nos ajuda a ter uma visão mais ampla da necessidade de construir uma prática educacional que integre inteligência e intelecto, racionalidade e sensibilidade, soma e psique, enfim, que considere o ser humano em sua totalidade, possibilitando-lhe o desenvolvimento de suas potencialidades. Neste contexto, as atividades lúdicas se mostram como um recurso valioso, uma vez que integram pensamento, sentimento e ação, abrindo espaço para a integração dos três cérebros e criando condições para que a intuição se manifeste, enfim, propiciando a expansão da consciência (PEREIRA, 2004, p. 92).

Outros pesquisadores discorrem acerca do contexto lúdico e das contribuições deste espaço tanto para crianças quanto para adultos. Tratando das relações entre jogo e educação, também salientam o valor do jogo na escola, nas universidades, nas salas de aula em geral, sinalizando-o como recurso pedagógico. Algumas pesquisas advêm da área da educação. Outras, mais especificamente, das áreas de Educação musical, Teatro-educação, etc.

Ao pensar as relações entre teatro e educação, a professora e diretora teatral norteamericana Viola Spolin (1906-1994) criou, pioneiramente, uma proposta de ensino do teatro por meio de jogos teatrais.

\begin{abstract}
A sistematização de uma proposta para o ensino do Teatro, em contextos formais e não-formais de educação, através de jogos teatrais, foi elaborada pioneiramente por Viola Spolin ao longo de quase três décadas de pesquisas junto a crianças, préadolescentes, adolescentes, jovens, adultos e idosos nos Estados Unidos da América. Utilizando a estrutura do jogo com regras como base para o treinamento de teatro, Viola Spolin ambicionava libertar a criança e o ator amador de comportamentos de palco mecânicos e rígidos. Seus esforços resultaram no oferecimento de um detalhado programa de oficina de trabalho com a linguagem teatral destinado a escolas, centros comunitários, grupos amadores e companhias teatrais (JAPIASSU, 1998, p. 85).
\end{abstract}

Spolin (2008, 2012a, 2012b) apresenta diversos argumentos para a prática de jogos em ambientes pedagógicos. A seu ver, o jogo é democrático (espaço em que todos podem aprender), desperta a pessoa como um todo, é altamente social, oferece aos alunos o exercício da liberdade e do respeito pelo outro, propicia experiências no nível da intuição, dentre outras 
contribuições. Considerando os efeitos do ato de jogar, esta professora e diretora teatral pensou a abordagem do teatro em sala de aula por meio dos jogos.

No trabalho com o jogo em suas oficinas de teatro, Spolin (2012a, 2012b) não descaracteriza este contexto lúdico, mantendo os critérios/características do mesmo. Também não o reduz a uma "atividade recreativa” ou como meio para que, simplesmente, transmitamse conteúdos curriculares. O que se percebe é que o jogo (em suas diversas nomeações, seja quando considerado jogo tradicional, ou jogo teatral, dentre outros) tem potencial educativo, como já tratado anteriormente neste trabalho. Assim sendo, pode se tornar "um recurso pedagógico que desencadeia aprendizagens mais abertas, propiciando a aquisição de conhecimentos e ampliando a potencialidade e as possibilidades lúdicas dos estudantes” (PEREIRA, 2012, p. 68).

Spolin (2008, 2012b, 2012b) faz proveito do jogo no ensino do teatro como espaço para liberdade, improvisação, incertezas, resoluções de problemas, tomada de decisões, etc. Segundo ela, "uma criança só poderá trazer uma contribuição honesta e excitante para a sala de aula, por meio de uma oficina de teatro, quando lhe damos liberdade pessoal. O jogador precisa estar livre para interagir e experimentar seu ambiente social e físico” (SPOLIN, 2012a, p. 31).

A autora ressalta que trabalhar com jogos teatrais pode parecer, para alguns professores, algo mais complicado, tendo em vista que estes devem esperar que os alunos façam descobertas por si próprios, sem que o professor aponte conclusões no lugar das crianças. Entretanto, salienta que ambientes assim propiciarão que os alunos atuem com liberdade, já que "se torna claro para os jogadores que nenhuma pergunta será feita que não saibam responder e nenhum problema será dado que não saibam resolver” (SPOLIN, 2012a, p. 39).

Em consonância com o pensamento de Pereira (2004), por exemplo, Spolin (2008, 2012a) também discorre acerca da necessidade de práticas educacionais que considerem o indivíduo como um todo, além de destacar a intuição como vital para a aprendizagem. A autora defende ambientes de ensino e aprendizagem em que a experiência - enquanto um envolvimento pleno, que abarca os níveis intelectual, físico e intuitivo - se concretize.

A experiência nasce do contato direto com o ambiente, por meio de envolvimento orgânico com ele. Isto significa envolvimento em todos os níveis: intelectual, físico e intuitivo. A intuição, vital para a aprendizagem, é muitas vezes negligenciada. A 
intuição é considerada como sendo uma dotação ou uma força mística possuída pelos privilegiados somente, embora todos conheçamos momentos quando a resposta certa "surgiu do nada" ou "fizemos a coisa certa sem pensar". [...] O intuitivo só pode ser sentido no momento da espontaneidade, no momento em que somos libertos para nos relacionarmos e agirmos, envolvendo-nos com o mundo em constante movimento e transformação à nossa volta (SPOLIN, 2012a, p. 31).

Para Spolin (2012a, p. 31), “a intuição vai além do intelecto, da mente, da memória, do conhecido. A utilização da intuição não pode ser ensinada. É necessário ser surpreendido por ela”. Enfatizando a importância dos momentos em que podemos usufruir da espontaneidade e, consequentemente, da intuição, Spolin (2012a, 2012b) considera os jogos teatrais como recurso para aprendizagem do teatro.

Por fim, pode-se citar ainda outro aspecto ressaltado pela professora no decorrer de sua atuação com os jogos teatrais: a superação da dicotomia professor versus aluno. A pesquisadora e professora Ingrid Koudela (1948-), discorrendo acerca dos jogos teatrais desenvolvidos por Viola Spolin, afirma que "o coordenador/professor e o aluno/atuante se tornam parceiros de um projeto artístico” (KOUDELA apud SPOLIN, 2012a, p. 22). O princípio da parceria é destacado por Koudela (2009), expondo-se a criação coletiva e a eliminação dos tradicionais papeis de professor e aluno como ideias-chave para compreensão dos jogos teatrais.

\footnotetext{
Algumas ideias-chave são essenciais para o entendimento do processo de Jogos Teatrais. A condição fundamental é a criação coletiva onde os jogadores fazem parte de um todo orgânico motivado pela ação lúdica. Aliada a essa condição está a eliminação dos papéis tradicionais aluno/professor, dicotomia superada pelo princípio de parceria. (KOUDELA, 2009, p. 148).
}

O professor, diretor teatral e pesquisador Antônio Januzelli (1940-), autor de obras como A aprendizagem do autor (2003), estuda a pedagogia do teatro, abrangendo também a importância do jogo nos processos de treinamento e de criação dos atores. Segundo Januzelli (2003), o jogo proporciona um espaço para improvisação, liberdade de criação e, consequentemente, para a descoberta do eu, para um conhecimento de si. Na opinião do autor, apenas sendo criativo o indivíduo pode se descobrir. Assim sendo, ressalta que "é no brincar, e talvez apenas no brincar, que o indivíduo frui sua liberdade de criação e utiliza sua personalidade integral: e é somente sendo criativo que ele descobre o eu” (JANUZELLI, 2003, p. 57). 
A intensidade do jogo é outro ponto analisado por Januzelli (2003). Assim como Huizinga (2012), que destaca a intensidade, o poder de fascinação do jogo, a capacidade de excitar e divertir, Januzelli (2003, p. 55) considera que é “nessa intensidade, nessa fascinação, nessa capacidade de excitar que reside a própria essência e a característica primordial do jogo”. Para Huizinga (2012, p. 13), o jogo "lança sobre nós um feitiço: é 'fascinante', 'cativante””. De acordo com ambos os autores, portanto, a essência do jogo estaria nessa capacidade de ser intenso, fascinante e propiciar o divertimento.

A intensidade do jogo pode ser analisada à medida que este nos permite uma abstração da realidade. Para Mihaly Csikszentmihalyi (apud PAREDES ORTIZ, 2005, p. 21), “o jogo leva a experimentar uma sensação de fluir que nos transporta a um entorno em que abstraímos a realidade e outras situações cotidianas, para passar a expressar-se como somos, com toda a personalidade, nossas carências e virtudes”.

Outros autores destacam este contexto lúdico como meio que propicia transformação e abstração da realidade, além de uma suspensão para um “mundo irreal”. José Ortega y Gasset (apud PAREDES ORTIZ, 2005, p. 20) compreende o jogo como "a arte ou a técnica que o homem possui para suspender virtualmente sua escravidão dentro da realidade, para fugir, levar-se para o mundo irreal”. Patrícia Margarida Farias Coelho (2001), por exemplo, também aponta para uma realidade versus um "mundo do jogo", mundo em que o jogador entra e, a partir de então, pode vivenciar experiências sem correr riscos reais.

\footnotetext{
O jogo se apresenta ao jogador como a possibilidade dele (jogador) poder ter vários tipos de experiências sem que corra riscos reais, onde é possível que ele brinque e desenvolva suas atividades cognitivas em um universo lúdico, em que não há a força e peso da realidade, ou seja, ao entrar no mundo do jogo, o jogador pode se sentir, mesmo que temporariamente, afastado da realidade em que vive e ir 'viver' de modo seguro em outro mundo que lhe dá prazer. Essa prática e imersão do jogador 'de estar no jogo' é o que caracteriza o jogo (COELHO, 2001, p. 305).
}

O fato de o jogo não ser vida “real”, mas sim uma evasão desta, é tratado por Huizinga (2012) como uma das características deste contexto lúdico. Após apresentar o jogo como livre, como atividade voluntária, Huizinga (2012, p. 11) afirma que "uma segunda característica, intimamente ligada à primeira, é que o jogo não é vida 'corrente’ nem vida 'real'. Pelo contrário, trata-se de uma evasão da vida 'real' para uma esfera temporária de atividade com orientação própria”. 
Considerando o jogo como ambiente para criação, improvisação, liberdade, descoberta de si, além de discorrer acerca da intensidade que reside no mesmo, Januzelli (2003) trata-o como “conteúdo básico de autodesenvolvimento individual e grupal” (JANUZELLI, 2003, p. 59). Destaca-o, ainda, como uma das únicas atividades coletivas permissivas à eliminação da autocensura, em que o jogador poderá atuar sem amarras.

Os jogos são atividades que envolvem ação global: corporal, mental, mnemônica, emotiva... Como exigem muita concentração num foco de atenção e a maioria deles prescinde de um treinamento aprofundado como pré-requisito, eles se tornam uma das únicas atividades coletivas onde, em prazo de segundos, inconscientemente, a auto-censura é automaticamente eliminada da ação. E aí está a sua sagrada virtude: no decorrer da atividade, o jogador atua na sua maior plenitude, sem amarras (JANUZELLI, 2003, p. 59).

O professor e pesquisador Eugênio Tadeu Pereira estuda as práticas lúdicas na formação de estudantes de teatro. Ao analisar a relevância de práticas vocais lúdicas com estudantes da licenciatura e do bacharelado da área em questão, Pereira (2012, p. 15) conclui que o jogo "amplia e diversifica as experiências dos estudantes, contribuindo para a compreensão e apropriação de procedimentos vocais, tão necessários à atuação profissional desses sujeitos”.

Pereira (2012) acredita no potencial educativo do jogo, fazendo deste um recurso pedagógico. Assim como Lima (2008), que expôs diversas tendências acerca do jogo na educação, Pereira (2012) também apresenta reflexões que apontam para três vertentes: o jogo como instrumento pedagógico, o jogo como “maquiagem” e o jogo como recurso pedagógico, que desencadeia aprendizagens mais abertas.

Observa-se que há ações e reflexões apontando para três vertentes: na primeira, o jogo é visto como um instrumento pedagógico que desencadeia a pura e restrita aquisição de informações; na segunda, o jogo é visualizado como uma "maquiagem" no processo de aprendizagem, isto é, apresenta-se ao aluno um conjunto de atividades revestidas com a palavra "lúdico". Nesse caso, elas não passam de uma dinâmica para que alguns conteúdos escolares sejam transmitidos e consumidos numa roupagem aparentemente divertida, mas que nada têm de lúdico em seu fundamento. Observamos que nem toda atividade ou exercício denominado de lúdico é jogo. Essas atividades podem conter traços que nos remetem à situação lúdica, mas não passarão de uma "atividade dinâmica”. Por fim, na terceira vertente, encontramos o jogo como um recurso pedagógico que desencadeia aprendizagens mais abertas, propiciando a aquisição de conhecimentos e ampliando a potencialidade e as possibilidades lúdicas dos estudantes (PEREIRA, 2012, p. 68). 
Na concepção de Pereira (2012, p. 68), pensar o jogo como recurso pedagógico “implica em relacionar suas características básicas com seu aspecto de mediador na apropriação do conhecimento”. Isto significa, portanto, manter as características do jogo, ainda quando este é empregado na sala de aula.

O autor compreende o jogo como um acontecimento delimitado em tempo e espaço, conduzido por regras, e caracterizado pelo ato volitivo do sujeito, ou seja: há condição e possibilidade de decisões, e não apenas uma estrutura pré-fixada, uma sequência de condutas já marcadas e externas ao jogador. Em seu entendimento, sem a ideia de volatilidade o jogo não existe.

Pereira expõe em seu trabalho um resumo acerca das características do jogo e a conceituação utilizada por ele em sua pesquisa.

\footnotetext{
Em síntese, o jogo é um conjunto de gestos, sons e significados que se friccionam e se integram em um determinado instante e lugar, nos quais o sujeito escolhe, relaciona, interage, experimenta, expressa, comunica e se declara como protagonista da ação. A situação lúdica é complexa e diversa em seu sentido. A cada jogo, dependendo do contexto, o sentido é dado por aqueles que o jogam. Na acepção exposta, o jogo é um acontecimento volitivo e conduzido por regras implícitas e explícitas, estruturado e delimitado em um espaço e tempo ficcionais, e que, no fluxo de sua existência, propicia escolhas e resultados incertos, gerando experiências aos jogadores e ocasionando vínculos e significados entre aqueles que jogam (PEREIRA, 2012, p. 85).
}

Muitos outros profissionais das artes cênicas também recorreram ao jogo - e ainda recorrem - ao pensar os processos pedagógicos. Pode-se encontrar uma variedade de obras que relacionam este contexto lúdico à educação, dentre estas trabalhos como os de Japiassu (1999), Kishimoto (1993, 19995, 1998), Pupo (1997), Reverbel (1993), Ryngaert (1981, 2009), etc. - além de obras já citadas, tais como de Koudela (2009) e Spolin (2012a, 2012b). A presença do jogo, portanto, é constante na área do teatro. Como afirma Lombardi (2005, p. 87), “Teatro e Jogo são inseparáveis. O jogo está sempre presente na interpretação do ator; no gesto; na modulação e no ritmo quando da emissão do texto; nas atividades educacionais do teatro; na dramaturgia; nas interações entre personagens”.

Na área da música, entretanto, não se faz tão notória a presença do jogo como recurso pedagógico (ZANETTA, 2014b). O que ainda se observa na Educação Musical é a constante presença de métodos e materiais didáticos que estruturam sistematicamente os conteúdos a serem trabalhos em sala, pensando-os como conhecimentos a serem transmitidos aos alunos 
via professor. Torna-se perceptível, no decorrer do tempo, que "a metodologia para o ensino de música tem mantido um padrão conservador em uma gama considerável de instituições, aplicando e repetindo fórmulas e conteúdos vigentes desde há muito, que prescindem de aspectos importantes da educação musical” (BELLODI, FONTERRADA, 2006, p. 923).

Acredito que isto ocorra já que, igualmente, a ideia de criação encontra dificuldade para se estabelecer nos processos de ensino e aprendizagem da música. A reprodução de obras, o ensaio técnico e a formação do virtuose ainda são priorizados, e não o estímulo ao criar.

\begin{abstract}
Em grande parte das escolas de música e entre professores particulares, constata-se que o ensino caracteriza-se, principalmente, pela prática da repetição, carecendo de estímulo ao desenvolvimento dos processos criativos e da improvisação, o que torna o aprendizado musical pouco atraente, por mostrar-se desvinculado de uma prática lúdica e de uma vivência sonora rica e estimulante (BELLODI, FONTERRADA, 2006, p. 924).
\end{abstract}

A partir dessa concepção, em que professores de música compreendem as aulas como momentos para transmitir conhecimentos de forma unilateral, sem pensar a criação imbuída neste processo, como se conceberá o jogo nas metodologias de educação musical? Afinal, para ser jogo, precisa haver espaço de liberdade, improvisação, criação, escolhas, atos volitivos dos indivíduos participantes... Ao jogo não cabe o discurso narrativo (esta unilateralidade) de um professor de música, mas sim o constante diálogo e uma parceria em atos de criação. Entretanto, como já apontado, a área carece também de espaços que valorizem o desenvolvimento dos processos criativos. Forma-se, assim, um ciclo: um aprendizado desvinculado do jogo e, consequentemente, do criar e/ou vice-versa: um aprendizado distante do criar e, portanto, do jogar com os sons.

Esta “lacuna criativa”, presente ainda nos dias de hoje na área da educação musical, é abalizada por Bellodi e Fonterrada (2006). Os autores sinalizam alguns problemas que despontam em virtude desta lacuna: (1) deixam de emergir criadores em potencial e (2) temse uma educação parcial, em decorrência da falta de conhecimento acerca da importância dos trabalhos de criação, dos trabalhos que levem em conta o emprego do pensamento.

A aplicação de procedimentos que estimulem a criatividade gera, assim, outra concepção pedagógica, que vem suprir esta lacuna criativa presente na abordagem do ensino musical ainda nos dias de hoje, lacuna esta que, não somente impede de fazer emergir muitos criadores em potencial, mas denota, também, a falta de 
conhecimento, por parte de professores e escolas, da importância do trabalho de composição, deixando de atribuir um justo valor aos compositores e às suas criações, o que acarreta uma educação parcial, limitada, que deixa de atentar para a importância de se encorajar o emprego do pensamento e da atitude criativos (BELLODI, FONTERRADA, 2006, p. 923).

Apesar destas problemáticas, algumas propostas ligadas a ideia de jogo e/ou processos criativos surgiram na educação musical nas últimas décadas. Curiosamente, muitas destas propostas foram realizadas por compositores que, interessados em influir no processo pedagógico da música, buscaram “incorporar à prática da educação musical nas escolas os mesmos procedimentos dos compositores de vanguarda, privilegiando a criação, a escuta ativa, a ênfase no som e suas características, e evitando a reprodução vocal e instrumental do que denominam 'música do passado’” (FONTERRADA, 2008, p. 179).

Tendo em vista as poucas abordagens acerca do jogo nas metodologias de educação musical, buscou-se abarcar na parte inicial deste trabalho a sua importância como recurso pedagógico. Por sua vez, o próximo tópico será dedicado ao valor dos processos criativos no ensino e aprendizagem da música, considerando a "lacuna criativa” existente na área e, consequentemente, a necessidade de voltarmos a atenção à criação.

\subsection{A CRIAÇÃO NA EDUCAÇÃO MUSICAL}

Embora tenham emergido métodos e propostas de educação musical ao longo do século XX (muitos buscando uma valorização das atividades de criação), além de surgido pesquisas que, atualmente, refletem acerca da importância dos processos criativos na área, persistem propostas que relacionam educação musical apenas ou prioritariamente à reprodução de músicas (BRITO, 2007; ZANETTA, 2014b).

Brito (2007) discorre a respeito desta temática, demonstrando como concepções de música e de formação musical em vigor no século XIX ainda se fazem presentes, até mesmo, na educação musical com crianças. A autora afirma que estas concepções se refletem até mesmo

no território da educação infantil (mas, não apenas neste domínio), onde o trabalho com a música (quando acontece!) é realizado com crianças com idades abaixo de 
seis anos de idade. Entender que fazer música é, via de regra, unicamente reproduzir modelos prontos (cantar as canções ou "musiquinhas”, como costumeiramente são chamadas; ensaiar arranjos pré-determinados tocados nos instrumentos da bandinha, realizar coreografias sempre marcadas etc), como não é raro acontecer, decorre da força de tais concepções, dentre outros aspectos (BRITO, 2007, p. 58-59).

Podem-se levantar, portanto, algumas questões: Por que ainda presenciamos tais concepções na área da educação musical? Por quais motivos muitas das aulas de música com crianças cedem espaço à reprodução, mas não à criação? Brito (2003) aponta algumas possíveis respostas. Segundo a autora, a ausência de profissionais especializados, assim como a atuação de educadores que não possuem formação musical, constituem algumas das causas. Além destas, pode-se citar a existência de uma concepção enraizada acerca da música e o caráter de espetáculo que é atribuído, frequentemente, ao trabalho musical (e que acarreta em meses dedicados à reprodução e ensaio de obras que são apresentadas em comemorações festivas, por exemplo).

Faz-se interessante observar que em outras áreas artísticas, entretanto, a criação parece ter “conquistado seu lugar” nos processos pedagógicos, seja nas aulas de artes visuais, de teatro, de cinema... Nas artes cênicas, por exemplo, têm-se o grande espaço dedicado aos jogos nas salas de aula e, consequentemente, à criação. Seja com crianças ou adultos, portanto, há uma preocupação em promover um ambiente em que os alunos possam improvisar e criar. A partir destes processos criativos, criam-se roteiros, formam-se personagens e as peças a serem apresentadas são trabalhadas/construídas.

Outro exemplo pode ser dado nas artes visuais, em que os desenhos prontos oferecidos às crianças para serem coloridos ou os materiais entregues para serem copiados estão cada vez mais distantes (BRITO, 2003, p. 52). O compositor canadense Murray Schafer (1933-) estabelece, inclusive, um paralelo entre as artes visuais e a música, declarando que

enquanto encorajamos a auto-expressão nas artes visuais (e penduramos os produtos nas galerias de arte, como testemunho da percepção dos nossos jovens), o paralelo em música é em geral pouco mais que memorizar Monkey in the Tree, para alguma apresentação social de fim de ano (SCHAFER, 2011, p. 273).

Por fim, ao pensarmos no cinema, talvez se torne até difícil imaginar um processo pedagógico que não incentive a criação. Todo ano têm-se novos “filmes em cartaz”, novas criações/produções concorrendo nos festivais e concursos da área, e não uma reprodução de obras já conhecidas. Para fins de comparação, pode-se pensar nas “salas de cinema” versus 
“salas de concerto”: quando o público se dirige à primeira, encontra novas obras a cada novo ano, semestre, quando não a cada mês! Nesta área, inclusive, tende-se a desvalorizar quando a “sala” mantém o mesmo filme em cartaz durante longo período. A procura é pelas novas obras. Já na sala de concerto, podemos até encontrar novas peças, porém, em geral, prevalece um repertório já reproduzido durante décadas e séculos. Para além, observa-se que, ao contrário de uma sala de cinema, a sala de concerto torna-se até valorizada quando anuncia tocar uma "grande obra”, uma peça de um “grande compositor”, ainda que esta já tenha sido reproduzida inúmeras vezes. Assim, percebe-se que uma área valoriza a criação, o novo, e, a outra, permanece bastante atrelada ao passado.

Koellreutter (1997d, p. 39-40) sinalizou este atrelamento ao passado na área da música, enfatizando que a maioria das escolas de música, apenas “fabricando" intérpretes e preparando-os em habilidades instrumentais, formam musicistas que objetivam reproduzir um repertório inúmeras vezes já realizado, reforçando assim os valores chamados “eternos”.

Refletindo acerca da educação musical, muitos educadores têm apontado a importância dos processos criativos e a necessidade destes se fazerem presentes no processo pedagógico da música. Tais colocações advêm considerando-se o valor da criação nas artes; contextos de ensino e aprendizagem que sejam significativos aos alunos (ambientes em que podem aprender, por exemplo, no decorrer da invenção de suas próprias obras e por meio das mesmas); o olhar às peculiaridades, uma prática que invista na produção de singularidades; e também pela "necessidade de gerar ambientes propiciadores de exercícios do pensamento" (BRITO, 2007, p. 9).

Em um trabalho com a educação infantil, por exemplo, Brito (2003, p. 45) destaca que é importante "considerar legítimo o modo como as crianças se relacionam com os sons e silêncios, para que a construção do conhecimento ocorra em contextos significativos, que incluam criação, elaboração de hipóteses, descobertas, questionamentos, experimentos, etc.”.

Para Fonterrada (2008), a valorização da peculiaridade e das singularidades aponta para o valor das atividades criativas. Ao mostrar-nos as diferenças entre concepções de mundo baseadas no modelo mecânico e na visão sistêmica, a autora relata que, nesta última,

as partes individuais podem comporta-se de maneira singular e irregular sem qualquer relevância na ordem e no funcionamento geral do sistema. Em vez da regularidade do sistema mecânico, o que se mostra é a peculiaridade. É por causa dessa característica, em especial, que se começa a compreender o valor das artes e 
das atividades criativas, que respondem exemplarmente a essa necessidade (FONTERRADA, 2008, p. 343).

Outros autores versam a respeito desta temática. Dentre estes, o compositor e educador Hans-Joachim Koellreutter, que apresentou propostas de educação musical voltadas, principalmente, à importância da criação e da improvisação no processo pedagógico. Koellreutter foi um dos compositores que, ao longo do século XX, buscaram incorporar os procedimentos de vanguarda e o valor da criação à prática da educação musical. Sua ampla atuação no Brasil como instrumentista, compositor, ensaísta e educador, gerou impacto no cenário musical brasileiro.

Considerando as inúmeras contribuições de Koellreutter à área da educação musical, além de sua importância, em específico, para esta pesquisa (tendo em vista suas reflexões acerca da criação no processo pedagógico, afora os diversos jogos de improvisação criados durante sua trajetória), explanarei algumas das proposições do educador. Compreendendo os limites deste trabalho (e também o interesse em destacar o jogo e os processos criativos no ensino e aprendizagem da música), algumas informações a respeito da vida de Koellreutter serão tratadas superficialmente, de maneira a aprofundar, mais especificamente, as contribuições de seu pensamento para a educação musical.

\subsection{HANS-JOACHIM KOELLREUTTER}

Hans-Joachim Koellreutter nasceu em Freiburg, Alemanha, no ano de 1915. Passou a estudar música sozinho, durante a adolescência, em sua própria casa, dedicando-se à flauta, piano, teoria e harmonia musical. Anos mais tarde, contrariando a vontade do pai e da madrasta, decidiu dar continuidade aos estudos de música e fugiu em um trem em direção a Berlim. Tornando-se aluno da Staatliche Akademische Hochschule für Musik entre 1934 e 1936, Koellreutter estudou flauta, piano, musicologia, composição e regência. Frequentou também, neste período, os cursos de composição moderna ministrados por Paul Hindemith (1895 - 1963), além de realizar suas primeiras apresentações como flautista em recitais na cidade de Paris. 
Enquanto permaneceu na Alemanha, tornou-se militante antinazista, criando, inclusive, o Círculo de Música Nova: grupo com objetivo de manifestar-se contra a política cultural nazista. Por ser contrário a esta política, enfrentou diversos problemas no decorrer de sua formação, como, por exemplo, sua expulsão da Academia de Música em Berlim.

\begin{abstract}
Logo me tornei militante antinazista, criando em 35 o 'Círculo de Trabalho para a Nova Música' ('Arbeitskreis fürNeue Musik’). Era um grupo contra o nazismo e sua política cultural, desafiando a Gestapo. Eu era realmente militante, lutava na rua e apresentava obras de vanguarda, o que irritou a Câmera de Música do Reich ('Reichsmusikkammer'). Isso não durou muito tempo. Exigiam na Academia que eu entrasse para o Partido Nazista. Eu recusei e me expulsaram (KOELLREUTTER, 1999, s/p).
\end{abstract}

Após sua expulsão, recorreu ao regente Hermann Scherchen (1891-1966), reconhecendo, posteriormente, a importância deste em sua formação musical e também na formação de seu caráter. Quando questionado acerca da influência deste regente em sua trajetória, Koellreutter responde:

É a pessoa que mais me formou. [...] Scherchen é sem dúvida o homem que mais me influenciou, também como caráter, forma de trabalhar, intensificar as coisas. Ele abriu realmente tudo, ensinou a evitar preconceitos, abrir a todas tendências. Foi talvez o mais importante que aprendi com ele. E também trato disso até hoje como princípio principal (KOELLREUTTER, 1999, s/p).

Koellreutter tornou-se noivo de uma judia. Esta atitude - além de suas diversas manifestações contra o nazismo - irritou sua família, que era de tendência monarquista e simpatizante dos nazistas. Consequentemente, o músico foi denunciado à Gestapo pela própria família e, posteriormente, foi expulso de seu país. Questionado sobre o porquê da denúncia feita pela família, Koellreutter respondeu:

Porque eram de tendência monarquista e portanto simpatizantes dos nazistas. Não queriam que me casasse com uma judia. Era o que se chamava 'crime racial'. Meu tio, irmão de meu pai, era amigo pessoal de Hitler e manejou isso [...] O filho desse tio organizava estudantes nazistas na Suíça e soube que minha noiva era judia. Disse não ter nada comigo, 'um pró-semita, comunista', mas armou uma surra na moça numa ponte de Genebra (KOELLREUTTER, 1999, s/p).

Em meio a estes conflitos, o músico precisou sair da Alemanha, chegando ao Brasil, no Rio de Janeiro, em novembro de 1937. 
Sua atuação no Brasil, ainda nos primeiros anos de morada no país, é bastante ampla. Logo no ano seguinte de sua chegada, por exemplo, realizou turnês pelo norte do Brasil, acompanhado do pianista Egydio de Castro e Silva. Ainda em 1938, começou a lecionar no Conservatório Brasileiro de Música, no Rio de Janeiro. Também neste ano, em articulação com outros compositores, criou o movimento Música Viva ${ }^{7}$ - movimento de muita importância na história da música no Brasil e, consequentemente, bastante estudado por pesquisadores musicólogos e outros profissionais. Para Koellreutter (1999, s/p), tratava-se de "um movimento de compromisso com o desconhecido, o contemporâneo e a renovação. VillaLobos era o presidente de honra. A pauta era educação, criação, conferências, concertos, programas de rádios, edições”. Suas principais características, segundo Kater (2004. p. 89), abarcam “o ineditismo de propostas na área cultural, atualidade do pensamento musical, convergência com tendências estéticas, filosóficas e políticas da vanguarda internacional”.

O Música Viva dinamizou o cenário cultural brasileiro no decorrer da década de 1940, tendo em vista que seus integrantes atuavam compondo, executando novas obras, divulgandoas em apresentações e em programas de rádios, realizando palestras, cursos, publicando boletins, etc. "Educação”, “Criação” e “Divulgação” eram consideradas práticas constituintes do tríplice enfoque deste movimento.

\begin{abstract}
Enquanto movimento que foi, Música Viva gerou intensa dinâmica cultural, agregando ao amplo conjunto de atividades promovidas - concertos, audições experimentais, conferências, cursos, programas de rádio, edição de boletins e de partituras, etc - temas contemporâneos para reflexão e oportunidades instigantes para debates. Todas essas iniciativas ofereceram-se como ricas alternativas de participação, provocando um aceleramento na compreensão da arte, do músico e de seus respectivos papéis na sociedade de sua época. Música Viva foi um movimento musical concebido sob o tríplice enfoque: Educação (formação) - Criação (composição) - Divulgação (interpretação, apresentações públicas, edições, transmissões radiofônicas), que integrados tiveram intensidades proporcionais ao longo de sua existência (KATER, 2004, p. 89).
\end{abstract}

Foram muitas as atuações de Koellreutter após sua chegada ao Brasil. Para citar algumas, pode-se destacar que o músico foi (1) fundador do Quinteto Instrumental de São Paulo em 1942; (2) integrante da OSB - Orquestra Sinfônica Brasileira, como flautista, a

\footnotetext{
${ }^{7}$ Tendo em vista que as primeiras atividades significativas do movimento iniciam-se no ano seguinte, alguns consideram o ano de 1939 como data de criação do Música Viva.
} 
partir de 1944; (3) professor de composição de renomados músicos, tais como César GuerraPeixe e Edino Krieger; (4) inaugurador da tradição dos cursos e festivais de férias no país, dirigindo, em 1950, o Curso Internacional de Férias Pró-Arte no Rio de Janeiro; (5) fundador da Escola Livre de Música de São Paulo no ano de 1952, sendo também professor da instituição e diretor da mesma até 1958; (6) fundador dos Seminários Internacionais de Música, na Bahia, em 1954 - seminários estes que se transformaram na Escola de Música e Artes Cênicas da Universidade Federal da Bahia (UFBA), da qual Koellreutter foi diretor até 1962; (7) professor no Conservatório Brasileiro de Música no Rio de Janeiro e no Instituto Musical de São Paulo; (8) criador também do Centro de Pesquisa em Música Contemporânea da Universidade Federal de Minas Gerais (UFMG), em 1985; (9) na Índia, em 1966, foi fundador da Escola de Música de Nova Delhi; (10) em Tóquio, no ano de 1969, tornou-se diretor do Instituto Cultural da República Federal Alemã; (11) diretor do Conservatório Dramático e Musical de Tatuí/São Paulo entre 1983 e 1984; (12) professor-visitante, em 1984, na Pontifícia Universidade Católica (PUC) de São Paulo, como também na Universidade de São Paulo (USP) entre os anos de 1987 e 1989; etc.

\footnotetext{
Durante todo esse período Koellreutter teve múltipla atuação, seja como flautista, seja como compositor, regente, divulgador ou teórico. Mas foi, a meu ver, à área educativa e pedagógica que ele legou o melhor de sua contribuição para nós, justamente onde defrontamos maior carência de estudos, reflexão e propostas. (KATER apud BRITO, 2011, p. 14).
}

As contribuições de Koellreutter para a educação musical foram muitas e, como se pôde observar nos exemplos elencados acima, abarcaram também o nível institucional, com sua participação em conservatórios, universidades ou em institutos culturais (ZANETTA; BRITO, 2014).

O educador atuou em diferentes espaços voltados à formação de novos músicos, entretanto, suas proposições pedagógicas não foram abraçadas ou compreendidas por todos. As ideias de Koellreutter acerca da música e do ensino de música no país foram seguidas por alguns enquanto, simultaneamente, causaram ira a outros. Como relata Teca Alencar de Brito, o nome de Koellreutter é associado ao movimento Música Viva assim como "à ira que causou aos compositores tradicionalistas, que não conseguiam ver em suas posturas estéticas o desejo de transformação do ser humano” (BRITO, 2011, p. 28). 
Quer gerassem polêmicas, quer fossem abraçadas, as proposições lançadas por Koellreutter no cenário brasileiro "movimentaram e provocaram a emergência de significações para a educação musical, marcando a história da música no país” (ZANETTA; BRITO, 2014). Considerando, portanto, a estima deste compositor para a educação musical, além de suas ideias acerca da importância da criação e dos jogos de improvisação para o ensino e aprendizagem da música, serão abarcados neste trabalho os princípios orientadores de sua postura como educador, assim como as proposições pedagógicas e reflexões apontadas pelo músico.

\subsubsection{Koeullretter e a educação: o pensamento pedagógico-musical do educador}

O alicerce do ensino artístico é o ambiente. Um ambiente que possa acender no aluno a chama da conquista de novos terrenos do saber e de novos

valores da conduta humana. O princípio vital, a alma deste ambiente, é o espírito criador. O espírito que sempre se renova, que sempre rejuvenesce e nunca se detém. Pois, num mundo em que tudo flui, é o que não se renova um empecilho, um obstáculo. Hans-Joachim Koellreutter

Em todas as suas facetas, fosse compondo, interpretando ou dando aulas, Koellreutter estabeleceu um compromisso com o "novo": divulgou a "nova música” e novas técnicas composicionais, ressaltou a importância da criação (compreendendo o valor do criar em meio às artes e incentivando que os músicos não se restringissem à reprodução), apontou a improvisação musical como ferramenta didática e escreveu diversos textos em que expôs suas concepções de arte, música e educação, trabalhando com ideias bastante inéditas para o seu tempo (ZANETTA, 2014a; ZANETTA; BRITO, 2014).

Koellreutter engajou-se intensamente no compromisso de difundir novas ideias de música (a criação do Música Viva, por exemplo, reflete tal esforço). O nome deste compositor no Brasil “esteve sempre associado à inovação, atualização e a um pensamento amplo e aberto em relação à música. Esta postura também refletiu em seu modo de pensar a educação musical no país” (ZANETTA, 2014a, p. 96). Assim, ao versar acerca da educação, 
Koellreutter mantém ideias que trabalhou no decorrer de toda sua trajetória como compositor: a importância da criação, da improvisação, do “novo”. Uma das questões essenciais em sua proposta foi, justamente, a "atualização de conceitos musicais, de modo a viabilizar a incorporação de elementos presentes na música do século $\mathrm{XX}$ no trabalho da educação musical” (BRITO, 2011, p. 20).

Sua postura ampla e aberta como compositor é, igualmente, vislumbrada na educação. O educador pensa os processos pedagógicos da música para a formação integral do indivíduo. A seu ver, trata-se de um processo que transcende os aspectos musicais, tendo como finalidade o desenvolvimento das capacidades humanas. Assim, a partir de uma visão aberta e integradora, ele propôs: “o humano, meus amigos, como objetivo da educação musical” (KOELLREUTTER, 1998, p. 44).

H.J Koellreutter desenvolveu um projeto de educação musical visando à formação integral do ser humano. Ampliar a percepção e a consciência, superar preconceitos, pensamentos dualistas e posturas individualistas, dentre outros pontos, eram também objetivos a serem alcançados, lado a lado aos aspectos musicais (BRITO, 2012, p. 101).

Nesta concepção, o diálogo, o debate entre os alunos, o respeito ao próximo, o aprender a escutar, a submissão de interesses próprios aos do grupo, a noção de coletividade, a interação entre os estudantes, a convivência, etc., consistiam em aspectos a serem trabalhados durante as aulas, juntamente às questões musicais.

Instaurar a noção de coletividade e interatividade nos processos pedagógicos, superando-se também a dicotomia professor versus aluno e as posturas individualistas no meio artístico, foram outros objetivos expostos. A educação musical era compreendida, portanto, como "espaço cujos planos de comunicação agregassem também a convivência, as trocas, o diálogo, ao invés de restringir-se aos conhecimentos musicais” (ZANETTA; BRITO 2014, s/p).

A educação musical como meio que tem a função de desenvolver a personalidade do jovem como um todo; de despertar e desenvolver faculdades indispensáveis ao profissional de qualquer área de atividade, como, por exemplo, as faculdades de percepção, as faculdades de comunicação, as faculdades de concentração (autodisciplina), de trabalho em equipe, ou seja, a subordinação dos interesses pessoais aos do grupo, as faculdades de discernimento, análise e síntese, desembaraço e autoconfiança, a redução do medo e da inibição causados por preconceitos, o desenvolvimento da criatividade, do senso crítico, do senso de responsabilidade, da sensibilidade de valores qualitativos e da memória, 
principalmente, o desenvolvimento do processo de conscientização do todo, base essencial do raciocínio e da reflexão (KOELLREUTTER, 1998, p. 43).

Outros pontos se destacam na proposta do educador, tais como sua opinião a respeito dos métodos e a sugestão de um ensino pré-figurativo. Koellreutter propunha, por exemplo, a superação do currículo fechado, acreditando que se deve ensinar "aquilo que o aluno quer saber” (KOELLREUTTER apud BRITO, 2001, p. 33). Em sua opinião, era preciso promover um ambiente em que as perguntas emergissem e, a partir destas, a aula decorreria. Por conseguinte, afirmava que os professores deveriam "aprender a apreender dos alunos o que ensinar” (KOELLREUTTER apud BRITO, 2011, p. 33). Dirigindo-se aos professores que orientava nos cursos de Atualização Pedagógica, o educador recomendava tal postura. Entretanto, relata a dificuldade dos professores em instaurar este ambiente onde os alunos indicam o quê deve ser ensinado.

Digo isto aos professores que oriento nas aulas de música: aprendam sempre das crianças e com elas o que vocês devem ensinar. Eles dizem que isto é muito difícil. Eu não penso assim. Se realmente há dificuldade isto deve-se ao ego; portanto, torna-se necessário superá-lo (KOELLREUTTER, 1997c, p. 137).

Discorrendo acerca destas concepções, foi enfático ao criticar o ensino de música no Brasil, denunciando uma estagnação deste, visto que valores doutrinários, assim como os métodos, permaneciam enraizados na educação musical.

\begin{abstract}
É necessário libertar a educação e o ensino artísticos de métodos obtusos, que ainda oprimem os nossos jovens e esmagam neles o que possuem de melhor. A fadiga e a monotonia de exercícios conduzem à mecanização tanto dos professores quanto dos discípulos. [...] Inútil a atividade daqueles professores de música que repetem doutoral e fastidiosamente a lição, já pronunciada no ano anterior. Não há normas, nem fórmulas, nem regras que possam salvar uma obra de arte, na qual não vive o poder da invenção. É necessário que o aluno compreenda a importância da personalidade e da formação do caráter para o valor da atuação artística e que na criação de novas ideias reside o valor do artista (KOELLREUTTER, 1997a, p. 31).
\end{abstract}

Logo, ao invés de uma aplicação de métodos e, consequentemente, de uma padronização do ensino, Koellreutter (1997a) defendia um espaço à criação, ao diálogo e aos questionamentos dos alunos, acreditando que o trabalho a ser desenvolvido em sala deveria partir de um diálogo e dos interesses dos estudantes. Defendendo tais ideais, o educador pronunciou: “meu método é não ter método” (KOELLREUTTER apud BRITO, 2011, p. 31). 
A partir das concepções defendidas, Koellreutter (1997b) sugeriu o ensino préfigurativo. Em contraposição ao ensino figurativo - aquele que é baseado em "moldes” e padrões preestabelecidos - o educador propôs o ensino pré-figurativo: aberto para que se construa um caminho durante o próprio caminhar, não baseado em padrões, livre de preconcepções. Em suas próprias palavras, um ensino que

Orienta e guia o aluno, não o obrigando, porém, a sujeitar-se à tradição, valendo-se do diálogo e de estudos concernentes àquilo que há de existir ou pode existir, ou se receia que exista. Um sistema educacional em que não se 'educa', no sentido tradicional, mas, sim, em que se conscientiza e 'orienta' os alunos através do diálogo e do debate. (KOELLREUTTER apud BRITO, 2011, p. 37).

As proposições koellreutterianas, como mencionado anteriormente, não foram bem recebidas por todos. Elas "visavam um ensino de música que atentasse para o desenvolvimento de capacidades humanas, preocupando-se com a substituição do individual pelo coletivo na arte - e, em decorrência, no mundo” (ZANETTA, 2014a, p. 101-102).

As ideias do educador “atingiam” as estruturas de ensino que estavam alicerçadas no país e, consequentemente, aos professores que defendiam estas causas. Eram as "normas caducas de conservatório" que, segundo Adriano e Vorobow (1999), estavam sendo sacudidas. Na reportagem intitulada A Revolução de Koellreutter, publicada pela Folha Mais, comenta-se que "A revolução de Koellreutter compreende um projeto artístico e humanístico de amplas dimensões [...] Sua pedagogia sacudiu normas caducas de conservatório e fez (literalmente) escolas Brasil afora, laboratórios de disciplina e inquietação” (ADRIANO, VOROBOW, 1999, s/p). Embora alguns não compreendessem e/ou criticassem sua proposta, Koellreutter permaneceu "movimentando” o cenário brasileiro, considerando que o essencial é o movimento ${ }^{8}$.

Independentemente das opiniões emergidas ante a atuação de Koellreutter, um fato pode ser claramente constatado: o músico gerou movimento em nosso país! Como ele mesmo considerava, “o mundo intelectual, cultural é um grande lago, onde todos nós jogamos pedras. Umas um pouco maiores, outras menores, mas nós

\footnotetext{
${ }^{8}$ O compositor, inclusive, permaneceu dando aulas de harmonia, contraponto, estética, dentre outras disciplinas, sempre com uma postura aberta, segundo princípios que defendeu como educador. Simultaneamente, Koellreutter também formava professores de música para trabalhar em contextos que não fossem voltados, especificamente, à formação de músicos, valendo-se da música como ferramenta importante para o desenvolvimento humano, sem a intenção da profissionalização.
} 
movimentamos esse lago. Isso é o que me parece essencial: o movimento.” (ZANETTA, BRITO, 2014, s/p).

Apontando a importância da criação, Koellreutter (1997c) vislumbrou a improvisação musical como ferramenta pedagógica propícia para instauração de um espaço comunicacional nas aulas de música (ZANETTA; BRITO 2014). Segundo o educador, a prática da improvisação permite o desenvolvimento de capacidades musicais e humanas, à medida que possibilita "vivenciar e conscientizar importantes questões musicais, que são trabalhadas com aspectos como autodisciplina, tolerância, respeito, capacidade de compartilhar, criar, refletir, etc.” (BRITO, 2011, p. 47).

\begin{abstract}
A improvisação era entendida como uma importante ferramenta pedagógica e ocupava lugar de destaque no projeto. H.J.Koellreutter desenvolveu uma série de modelos de improvisação focando questões musicais e humanas (como concentração, autodisciplina, comunicação e criatividade, dentre outras), entendidos como possibilidades abertas, sujeitas a transformações decorrentes da observação do professor, das ideias e sugestões dos alunos e, enfim, do contexto de cada situação (BRITO, 2012, p. 101).
\end{abstract}

Considerando a improvisação como importante ferramenta pedagógica, Koellreutter elaborou diversos jogos de improvisação (alguns nomeados modelos de improvisação e, outros, exercícios de comunicação) para o trabalho com a música em sala de aula, fornecendo um arsenal de ideias para professores de música. Por meio destes jogos, o educador pensou o desenvolvimento musical e humano, almejando práticas musicais coletivas que favorecessem “a convivência com o outro, o respeito, o aprender a escutar, aspectos como a autodisciplina, a submissão dos interesses próprios aos do grupo, o trabalho em equipe, entre diversas outras possibilidades” (ZANETTA; BRITO, 2013, p. 1027). Observa-se a preocupação do educador em desenvolver, através dos jogos, "tanto aspectos musicais, tais como exploração sonora, pesquisa de timbres, questões métricas e a notação musical, quanto aspectos humanos, como o respeito, o diálogo e o sentido do trabalho coletivo” (ZANETTA, 2014a, p. 96).

Assim como Lima (2008) e Spolin (2008, 2012a, 2012b), dentre outros pesquisadores e educadores já citados neste trabalho, H.J Koellreutter empregou o jogo como recurso pedagógico. Faz-se importante ressaltar que tais jogos de improvisação foram criados, pelo educador, em um período em que o ensino de música permanecia (e, como já apontado, ainda permanece) influenciado por modelos tradicionais. Entretanto, unindo as contribuições das 
práticas de improvisação ao ambiente do jogo, Koellreutter propôs um trabalho pedagógicomusical voltado à formação integral do ser humano.

\begin{abstract}
Interessante observamos que, já na década de 1980, Koellreutter ponderou o trabalho pedagógico-musical por meio da improvisação associada aos processos lúdicos, criando os modelos anteriormente citados. Desta forma, ao unir as práticas de improvisação (considerando o desenvolvimento de capacidades humanas e musicais por meio destas) ao ambiente do jogo (espaço propício para um trabalho em diversas instâncias), acreditamos que Koellreutter esteve à frente de seu tempo. Ele propôs um espaço educacional lúdico, de criação e comunicação, voltado à formação integral do ser humano: isto em um período em que o ensino de música, apesar da emergência de propostas inovadoras daqueles que formaram a segunda geração de educadores musicais (FONTERRADA, 2008), permanecia influenciado por modelos tradicionais (ZANETTA; BRITO, 2014, s/p).
\end{abstract}

Seus jogos são bastante importantes para esta pesquisa, tendo em vista que possibilitam pensar uma abordagem da música pelo viés da criação e da ludicidade, assim como uma integração entre música e teatro. Atentando para a estrutura dos jogos criados por Koellreutter, tal integração se esclarece: é possível observar a existência de papeis/personagens a serem representados pelos alunos (escolhidos livremente pelos participantes), regras, diálogo musical a ser desenvolvido entre as personagens (prevalecendo a incerteza - critério para que haja jogo - em relação a como este diálogo irá se desenvolver), divisão da turma entre jogadores e plateia, dentre outros aspectos.

Analisando alguns destes jogos, tais como Loja de relógios, Via Dutra enfeitiçada e Comício, percebem-se diversas semelhanças com os que são desenvolvidos na área do teatro principalmente com o modelo dos jogos teatrais, tendo em vista a divisão do grupo em jogadores e plateia, assim como a existência dos pontos de concentração “Onde”, “Quem” e "O quê".

Em diversos destes jogos, por exemplo, abre-se espaço para a exploração sonora e improvisação apenas após a prévia apresentação de cenário, escolha de personagens - cada participante ou grupo de participantes representando um dos personagens estabelecidos nas regras do jogo, além da divisão da turma em um grupo de jogadores e outro de observadores/plateia. Considerando estes critérios, podemos relacionar o trabalho desenvolvido por Koellreutter a jogos desenvolvidos na área do teatro, especificamente ao "modelo" do jogo teatral (ZANETTA, 2013, s/p).

Os jogos teatrais são considerados práticas lúdicas que abarcam representações, em ações improvisadas, dirigidas a uma plateia (JAPIASSU, 2003; NEVES, 2006; SPOLIN, 2008). A existência de uma plateia (grupo de observadores) é um ponto chave para 
compreensão deste modelo de jogo, possibilitando, inclusive, sua diferenciação do jogo dramático. Diversos autores têm trabalhado com esta perspectiva, dentre eles Japiassu (2003), Koudela (2009) e Neves (2006).

\begin{abstract}
Para entender a diferença entre o jogo teatral e o jogo dramático, é preciso lembrar que a palavra teatro tem sua origem no vocábulo grego theatron, que significa 'local de onde se vê' (plateia). Já a palavra drama, também oriunda da língua grega, quer dizer 'eu faço, eu luto'. No jogo dramático entre sujeitos, portanto, todos são 'fazedores' da situação imaginária, todos são 'atores'. No jogo teatral, o grupo de sujeitos que joga pode se dividir em equipes que se alternam nas funções de 'jogadores' e de 'observadores', isto é, os sujeitos jogam deliberadamente para outros que o observam (JAPIASSU, 2003, p. 19).
\end{abstract}

Spolin (2008) propõe uma estrutura ao jogo teatral, pensando-se nos pontos de concentração “Onde”, “Quem” e "O quê”. Os jogos teatrais, segundo a autora, são baseados em problemas a serem resolvidos coletivamente, durante ações improvisadas, e possuem estes pontos de concentração, esta estrutura dramática (SPOLIN, 2008). Assim sendo, estabelecer “onde” a ação improvisada acontecerá (local/espaço fictício onde será desenvolvida), “quem” as pessoas representarão (personagens/papeis a serem assumidos) e “o quê” farão (uma ação a ser realizada pelas personagens), permite delinear e contextualizar a ação dos jogadores. Spolin (2008) explica como estes pontos devem ser trabalhados:

Faça uma discussão com o grupo para estabelecer o foco no Ponto de Concentração primário (Onde) e secundário (Quem e O Quê). Inicie discutindo o onde [...] Quando a discussão sobre o Onde estiver terminada, os pontos de concentração acerca do Quem e O Quê devem ser cobertos muito rapidamente [...] E assim o ator deve ter suas razões para manipular certos objetos no palco, para estar num certo lugar, para atuar de um certo modo (SPOLIN, 2008, p. 82-84).

Esta estrutura - estes pontos de concentração - pode ser observada em diversos dos jogos de improvisação criados por Koellreutter (ZANETTA, 2013). Para fins de elucidação, uma breve análise de alguns dos jogos criados pelo educador será realizada. Através dos exemplos que serão levantados, faz-se possível perceber o contexto cênico-musical destes jogos.

O modelo intitulado Via Dutra Enfeitiçada pode ser analisado por meio dos pontos de concentração expostos anteriormente. Koellreutter sugere o “Onde” - que consiste na própria Via Dutra; o "Quem” - fantasma e motoristas; e o "O quê” - ações sonoras e gráficas que decorrem no jogo por meio da interação entre os motoristas e o fantasma. Através deste jogo 
de improvisação, o educador visava a conscientização de parâmetros do ensino musical (tais como o timbre, o ruído como objeto sonoro, dentre outros), em um trabalho que abarcava o registro gráfico dos sons. Desejava que as próprias crianças refletissem acerca das diversas possibilidades de representação sonora, escolha dos sons e maneiras de reproduzi-los. Koellreutter destaca, ainda neste jogo, que poderia ser interessante realizá-lo com uma troca de papeis (fantasma/motoristas), alterando-se as personagens no decorrer da ação lúdica.

A estrutura do modelo Loja de relógios consiste em outro exemplo passível de aproximações com os pontos de concentração dos jogos teatrais. Koellreutter propõe o “Onde” - uma loja de relógios; o “Quem” - as personagens serão as “cordas” e os “relógios”; e o "O quê" - alguns participantes responsáveis pela ação de "dar corda” e outros atentos ao momento de fazer seu "relógio" soar. Um jogo de comunicação se estabelece em ações sonoras improvisadas. Duas outras questões podem ser observadas: (1) Koellreutter sugere outras estruturas, variações ao jogo, formando o que ele chamou de "atuações” diferenciadas. O termo “atuação” é utilizado algumas vezes pelo educador e remete, também, à área do teatro. (2) Entre diversos apontamentos e sugestões, Koellreutter ressalta a possibilidade de se “criar variações para a ideia da Loja de relógios, levando o grupo a observar aeroportos, jogos de futebol, feiras, ou, então, realizando o trabalho também como uma peça de teatro” (KOELLREUTTER apud BRITO, 2011, p. 118). Portanto, o próprio educador sugeria a realização deste jogo como uma peça de teatro.

Pode-se ainda observar a estrutura do exercício de comunicação intitulado O Comício. Neste jogo, o ambiente de um comício - “Onde” - deve ser reproduzido musicalmente através da interação sonora entre os participantes - “O quê” - que serão um deputado e a multidão “Quem”.

Por meio destas breves análises faz-se possível perceber que, ao trabalhar com o jogo como recurso pedagógico, Koellreutter se aproxima de uma perspectiva de trabalho teatral não apenas ao sugerir uma divisão entre jogadores e plateia, mas estabelece, em diversos de seus modelos, o "onde” da ação, as personagens a serem representadas, a ação a ser desenvolvida e, além disso, aponta diferentes formas de "atuações” - isto quando não sugere que o próprio jogo seja realizado como uma peça teatral. O arte-jogo Fim de feira, por exemplo, chegou a ser apresentado como uma peça de teatro. Brito (2001) comenta acerca deste processo: 
O professor Koellreutter vislumbrou no arte-jogo Fim de feira a oportunidade de desenvolver um trabalho - a um só tempo - pedagógico e artístico, considerando também que seria muito interessante integrar música e teatro [...] Fim de feira propôs uma vivência cênico-musical com base em situações cotidianas [...] A ideia original pretendia desenvolver a improvisação num plano exclusivamente musical em que o discurso dos políticos, por exemplo, seria realizado unicamente por instrumentos musicais. O que ocorreu, no entanto, foi a integração de linguagens: gestos, sons, movimentos, falas, cores... (BRITO, 2001, p. 63-64).

Acredito que as aproximações com o teatro expostas acima decorram, primeiramente, do desejo de Koellreutter de que as áreas artísticas não fossem ensinadas separadamente. Segundo ele, “O espírito criador não permite - hoje menos que nunca - que os vários ramos da educação artística sejam ensinados independentemente, uns dos outros, sem relações entre si” (KOELLREUTTER, 1997b, p. 54-55). Não concordando com este trabalho fragmentado em meio às artes (que, ainda hoje, faz-se presente), Koellreutter estabeleceu relações entre diferentes áreas ao pensar suas propostas pedagógicas. Ele apontava a necessidade da educação musical não se limitar à música (KOELLREUTTER, 1997c). Além disso, sabe-se que o educador buscava ler e conhecer acerca dos mais diversos campos de estudo. Ele afirmava:

\footnotetext{
A tendência de todos os trabalhos que fiz foi sempre a interdisciplinaridade. Sempre me autoeduquei neste sentido. Se você quer fazer isso, deve estudar e ler constantemente livros, teses de outras áreas do conhecimento. Muitas vezes me perguntam em aulas públicas: “Onde o senhor estuda essas coisas?” Digo que não estudo isso em publicações sobre música. Em geral, leio trabalhos de Psicologia, Filosofia, Física, dentro dos conhecimentos que tenho. É claro que, para compreender um livro de Física, devo lê-lo duas ou três vezes. Explico aos alunos que há 10 ou 15 anos, pelo menos, não "leio" livros, mas sim "estudo" livros. Estudo capítulo por capítulo, parágrafo por parágrafo, e aplico isto à minha análise da música (KOELLREUTTER, 1997c, p. 134).
}

Em suas falas, entrevistas e também ao escrever ensaios, Koellreutter trabalhou com temáticas da educação (não se restringindo à educação musical), das artes (não apenas com o campo da música), da filosofia, da fenomenologia, da física, da psicologia, da linguagem e comunicação, etc. Durante o período em que ministrou os Cursos de Atualização Pedagógica (entre 1980 e início da década de 1990), por exemplo, indicou aos seus alunos a leitura de obras diversas, tais como: Arte e percepção Visual, do psicólogo alemão Rudolf Arnheim, Pequena estética, do filósofo alemão Max Bense, A mathematical theory of aesthetics, do matemático americano George David Birkhoff, O ponto de mutação e $O$ tao da física, ambos do físico austríaco Fritjof Capra, $O$ ocidente é um acidente, do filósofo francês Roger 
Garaudy, Física e Filosofia, do físico alemão Werner Heisenberg, Mutações em educação segundo McLuhan, do pedagogista brasileiro Lauro de Oliveira Lima, Fenomenologia da percepção, do filósofo francês Maurice Merleau-Ponty, Informação, linguagem, comunicação, do poeta e professor brasileiro Décio Pignatari, etc. Koellreutter compreendia a educação, portanto, no sentido amplo do termo. Questionado acerca da realidade brasileira e de suas observações a respeito da educação musical no país (observações que se iniciaram já em 1938, durante turnês que realizou no Brasil), percebe-se a ampla dimensão dada pelo educador ao ensino da música - além das diversas áreas de estudo pelas quais ele se interessava.

\begin{abstract}
Achava [já nos primeiros anos de residência no país] que o problema da educação musical na escola era muito importante, não só pela música em si, por que ela sempre existiu para mim num contexto maior, na ótica de uma espécie de humanismo. Ao mesmo tempo, considerava que a educação era um problema básico deste país, porém não no sentido estabelecido por Getúlio Vargas, no período do Estado Novo. Eu tinha mais experiência de Estado Novo que os brasileiros, porque eu vinha do Fascismo e do Nazismo. Pensei que se poderia fazer aqui oposição a isto que estava nascendo na Europa, contribuindo na área musical. Sempre estudei também em livros e revistas sobre outros temas, pois me interessava em aplicar a Antropologia, Psicologia, Filosofia, Física e outras áreas do conhecimento, de maneira interdisciplinar, à música. Busquei compreender até que ponto uma educação musical poderia visar, em primeiro lugar, o homem, e não restringir apenas à sua matéria específica (KOELLREUTTER, 1997c, p. 132).
\end{abstract}

Assim sendo, torna-se "natural" o fato dos jogos criados pelo educador terem estreitas relações com os jogos teatrais: considerando que seu discurso acerca de música e educação sempre esteve relacionado aos estudos dos mais diversos campos, é bastante plausível que, ao pensar propostas pedagógicas para a sala de aula, Koellreutter mantivesse tal coerência.

Observando a maneira como Koellreutter pensa o ensino da música, abarcando o trabalho da criação musical e, mais especificamente, da improvisação no contexto lúdico do jogo cênico-musical, busquei desenvolver a prática de minha pesquisa. Deste modo, considerando tanto a importância dos contextos lúdicos na educação - apontando o jogo como recurso pedagógico - assim como o valor dos processos criativos na educação musical, penso também o jogo cênico-musical como espaço para que as crianças improvisem em sala de aula.

Portanto, a proposta deste trabalho foi uma pesquisa-ação, colocando-se tais questões “em prática” no contexto de uma Oficina de Música para crianças. Tal proposta e as considerações metodológicas da pesquisa serão explicitadas no capítulo a seguir. 


\section{OFICINA DE MÚSICA: CONSIDERAÇÕES METODOLÓGICAS SOBRE A PRÁTICA DA PESQUISA-AÇÃO E O CAMPO DE ATUAÇÃO}

Nesta pesquisa buscou-se investigar as possíveis contribuições das experiências de improvisação em meio aos jogos cênico-musicais para a formação integral da criança, considerando a perspectiva das próprias crianças participantes de uma Oficina de Música ${ }^{9}$ para o embasamento e desenvolvimento da dissertação.

O termo cênico-musical foi utilizado para designar jogos que agregam tanto aspectos musicais (como pesquisas timbrísticas, improvisação musical, uso de instrumentos musicais convencionais ou não - para a criação, exploração de fontes sonoras diversas, dentre outros) quanto elementos teatrais (tais como as personagens representadas em cena e a existência dos pontos de concentração "onde", "quem" e "o que").

Deste modo, a questão de pesquisa que se coloca é: quais são as contribuições das experiências de improvisação em jogos cênico-musicais, sob as perspectiva das crianças, para a formação integral das mesmas?

\subsection{ABORDAGEM METODOLÓGICA}

Considerando que o interesse deste estudo está voltado ao ponto de vista das crianças envolvidas no processo, sendo situacional, orientado pelo “caso” (BRESLER, 2000), assim como direcionado para uma rica descrição das ações, a pesquisa configura-se como qualitativa (BRESLER, 2000; FLICK, 2009; STAKE, 2011). Segundo Bresler (2000), as investigações

\footnotetext{
${ }^{9}$ No Brasil, as primeiras propostas de Oficinas de Música foram realizadas no Departamento de Música da Universidade de Brasília, no ano de 1968 (SILVA, 1983). Estas iniciativas vieram ao encontro de novas posturas pedagógicas e musicais, que visavam ampliar o contato com o sonoro e o musical por meio de novos experimentos, novos materiais para a produção sonora, enfatizando a criação e a integração do grupo. No contexto da Oficina de Música, o fazer era fundamental. As reflexões teóricas, entretanto, não eram deixadas de lado, permeando o trabalho prático de criação (LATORRE, 2014; SILVA, 1983). Logo, o termo Oficina foi escolhido, nesta pesquisa de mestrado, por fazer jus à proposta do trabalho, considerando que foram realizadas práticas de jogos de improvisação, explorações sonoras, criação musical livre, além de reflexões acerca do fazer musical - tanto por meio de debates quanto nos protocolos confeccionados em todos os encontros.
} 
de abordagem qualitativa caracterizam-se, dentre diversos fatores, por terem interesse na singularidade, serem interpretativas e enfáticas, orientadas caso por caso, além de descritivas. Neste sentido, este estudo se adequa a tal abordagem, sendo interpretativo e enfático à medida que

interessa-se pelos diferentes significados que as ações e os acontecimentos têm para os diferentes participantes, assim como pelos seus pontos de referência, pelos seus valores, tendo em conta as presumíveis intenções daqueles que estão a ser observados. Faz-se uma tentativa para captar as perspectivas e percepções dos participantes, juntamente com a interpretação do investigador (BRESLER, 2000, p. 7).

Assim como descrito pela autora, esta pesquisa também se interessa pela perspectiva dos participantes envolvidos - expressas durante conversas, entrevistas e por meio dos protocolos - procurando captar seus pontos de vista para fundamentação do trabalho. Este interesse na observação do processo e nas interações entre os participantes do grupo estudado, assim como nas opiniões dos mesmos, são característicos da abordagem qualitativa, pois “diz respeito à importância que é atribuída ao significado das coisas. O investigador preocupa-se com cada resposta dos sujeitos, pois o importante é compreender o que significa, na perspectiva de cada um dos entrevistados” (CAMURRA, BATISTELA, 2009, s/p).

O olhar da pesquisadora, portanto, esteve voltado aos observados, na tentativa de interpretar situações por diversas vezes complexas e subjetivas. Para Bresler (2000), a interpretação é tarefa primordial do investigador. Logo, também como característica de uma abordagem qualitativa, a pesquisadora esteve voltada e constantemente conduzida pelo “caso”, procurando compreendê-lo. Ao indicar os diversos atributos de uma investigação qualitativa, Bresler (2000) aponta o fato desta ser orientada caso por caso. A respeito disso, a autora explica:

o "caso" a que nos referimos, poderá ser um aluno, um professor, a sala de aula, o currículo ou qualquer outro "sistema fechado". A investigação qualitativa é relativamente não comparativa, procurando entender cada caso, mais do que compreender o que o difere dos outros (BRESLER, 2000, p. 6).

Assim sendo, este trabalho se adequa à abordagem qualitativa também pelo fato de estar preocupado com o caso estudado por si só - mais do que com o levantamento de comparações. Neste sentido, buscou-se pensar e repensar as relações desenvolvidas entre as 
crianças por meio dos jogos vivenciados na Oficina, na tentativa de compreender melhor o contexto da pesquisa. Porém, o caso não foi estudado com objetivos maiores de traçar comparações ou, ainda, no sentido de formular métodos que pudessem ser aplicados e desenvolvidos em outros casos/contextos. O objetivo foi, justamente, apontar as singularidades vivenciadas, compreendendo que ainda que os mesmos procedimentos sejam realizados em outros grupos, pode-se chegar a diferentes resultados.

Visou-se também uma minuciosa descrição das ações, aspecto característico da pesquisa qualitativa (BRESLER, 2000; FLICK, 2009; STAKE, 2011).

[A investigação qualitativa] é descritiva. Há preferência por uma descrição em linguagem normal. Os dados recolhidos adquirem mais a forma de palavras e gráficos e não tanto de números. Os resultados escritos da investigação incluem citações que ilustram e fundamentam a sua apresentação. A informação fornecida pela apresentação da investigação proporciona experiências indiretas (BRESLER, 2000, p. 7).

Esta modalidade de pesquisa, por conseguinte, adquire o formato de uma descrição textual: um relato sobre as pessoas, o local de estudo e os processos interativos vivenciados entre os sujeitos participantes da pesquisa. Trata-se de uma pesquisa descritiva em que “rejeitando a expressão quantitativa, numérica, os dados coletados aparecem sob a forma de transcrições de entrevistas, anotações de campo, fotografias, videoteipes, desenhos e vários tipos de documentos” (GODOY, 1995, p. 62). Não há o objetivo, portanto, de uma enumeração ou mensuração dos eventos estudados, não se fazendo uso de métodos estatísticos. Assim como dito por Flick (2009, p.16), a abordagem qualitativa "usa o texto como material empírico (ao invés de números)”.

Outro fator apontado como característica desta abordagem metodológica é o prolongado envolvimento do pesquisador no ambiente de estudo. Desta forma, estabelece-se uma proximidade entre o pesquisador e os sujeitos pesquisados. Este fator, por sua vez, também foi observado na pesquisa em questão, tendo em vista que o trabalho atual despendeu um considerável período de tempo para a prática de uma pesquisa-ação. Além das aulas realizadas com o grupo de alunos participantes e das reuniões com os funcionários da escola, diversos encontros em horários variados foram necessários para que as entrevistas em grupo e individuais pudessem se concretizar. Como relata Bresler (2000, p. 7), “os investigadores qualitativos despendem, usualmente, um período de tempo considerável nas escolas, casas, redondezas e outros locais, tomando consciência das inquietações educacionais”. Bogdan e 
Biklen (1994), inclusive, consideram esta proximidade entre os sujeitos pesquisados e o pesquisador como uma das cinco características da investigação de abordagem qualitativa.

A coleta e análise de dados, nesta abordagem, também partem de alguns princípios. Deve haver um olhar holístico por parte do pesquisador: as interações observadas devem ser contempladas holisticamente, não sendo reduzidas a variáveis ou repartidas do todo, mas observadas em conjunto (GODOY, 1995). Todos os dados levantados são considerados importantes. É dado valor a todo o processo de pesquisa, não apenas ao produto. Inclusive, para Bodgan e Biklen (1994), esta seria uma das cinco características da abordagem qualitativa: a maior atenção dada pelos investigadores qualitativos não apenas aos produtos e resultados da investigação, mas a todo o processo.

A flexibilidade do processo de pesquisa é também fator característico desta abordagem. Não há uma definição das situações e ações a priori. Pode haver um planejamento e ideias-chave para a realização do estudo, mas estes, em geral, podem sofrer alterações no decorrer da atuação, à medida que as interações entre o grupo pesquisado vão sendo observadas e interpretadas. Desta forma, o processo de pesquisa não é claramente definido, mas sim flexível e imprevisível, movendo-se entre os eventos e a interpretação dos mesmos.

A própria coleta de dados e a sua análise ocorrem quase que simultaneamente (SAMPIERI et al., 2013, p. 33). Até mesmo a indagação inicial, o problema levantado no início da pesquisa, pode se modificar de acordo com as observações realizadas, sendo possível desenvolver questionamentos antes, durante e após os procedimentos de coleta e análise dos dados. Para Sampieri et al. (2013, p. 33), “a ação indagativa se move de maneira dinâmica em ambos os sentidos: entre os fatos e sua interpretação”. Como dito anteriormente, o interesse desta abordagem metodológica consiste no processo em si, que, por sua vez, é dinâmico e flexível.

Para finalizar a questão da abordagem qualitativa nas pesquisas, torna-se interessante observar a sua presença em estudos voltados à educação. Bresler (2000) versa acerca da pesquisa qualitativa na área da educação e, especificamente, na educação musical. Segundo a 
autora, ambas as áreas ainda são dominadas pela investigação quantitativa ${ }^{10}$, uma abordagem universalista a procura de informações que possibilita estudar, simultaneamente, vários casos diferentes, permitindo generalizações (BRESLER, 2000, p. 9-10). Segundo a autora, isto pode ser interessante. Porém, em sua opinião, "é evidente que o conhecimento mais significativo acerca da educação é situacional. Os investigadores qualitativos demonstram interesse pela singularidade do caso individual, pela variedade de percepções desse mesmo caso, e pelas diferentes intencionalidades dos atores que constituem esse caso” (BRESLER, 2000, p. 10). A partir do ano 2000, esta abordagem metodológica conquistou aceite na área da educação musical (BRESLER, 2000, p. 17).

\subsection{O MÉTODO PESQUISA-AÇÃO}

Na perspectiva de uma abordagem qualitativa, a pesquisa-ação foi o método escolhido para o desenvolvimento deste trabalho. Trata-se de

\footnotetext{
um tipo de pesquisa com base empírica que é concebida e realizada em estreita associação com uma ação ou com a resolução de um problema coletivo e no qual os pesquisadores e participantes representativos de situação ou do problema estão envolvidos de modo cooperativo ou participativo (THIOLLENT, 1988, p. 14).
}

Como expresso no próprio nome, este método visa unir a pesquisa à ação, possibilitando que o investigador desenvolva seu estudo a partir do envolvimento com uma prática. Diferencia-se de alguns outros modelos justamente pela intervenção do pesquisador, que se insere na ação não apenas como observador, mas modificando e conduzindo a prática da pesquisa. Engel (2000) versa sobre esta possibilidade de união entre teoria e prática, além desta característica de intervenção.

\footnotetext{
${ }^{10}$ Interessante apontar que esta informação reflete a respeito das pesquisas anteriores ao ano 2000, período em que o texto foi escrito pela autora. Portanto, não se pode afirmar que as pesquisas quantitativas, atualmente, predominem na área da educação musical. São necessárias novas investigações para compreensão destas questões no cenário da pesquisa em educação musical atualmente.
} 
A pesquisa-ação surgiu da necessidade de superar a lacuna entre teoria e prática. Uma das características deste tipo de pesquisa é que através dela se procura intervir na prática de modo inovador já no decorrer do próprio processo de pesquisa e não apenas como possível conseqüência de uma recomendação na etapa final do projeto (ENGEL, 2000, p. 182).

Outra característica inerente a este método é o fato de que ele conta com uma forma de ação planejada pelo pesquisador.

\begin{abstract}
A pesquisa-ação pressupõe uma participação planejada do pesquisador na situação problemática a ser investigada. O processo de pesquisa recorre a uma metodologia sistemática, no sentido de transformar as realidades observadas, a partir da sua compreensão, conhecimento e compromisso para a ação dos elementos envolvidos na pesquisa (FONSECA apud GERHARDT; SILVERA, 2009, p. 40).
\end{abstract}

Além destes aspectos, a pesquisa-ação permite que durante o desenvolvimento da prática levantem-se questões a serem discutidas. O pesquisador, no decorrer da própria ação, pode buscar e selecionar até mesmo o seu problema de pesquisa.

O objetivo, por meio deste método, foi buscar a perspectiva das crianças para atender a questão de pesquisa inicial, envolvendo-as em uma ação planejada no formato de uma Oficina de Música. Quando foi planejada tal proposta, partiu-se do desejo de não restringir a pesquisa e as problemáticas nela erguidas apenas aos referenciais teóricos estudados, mas da vontade de envolver também as opiniões e reflexões dos próprios participantes de uma ação. A escolha deste método se deu também pelo gosto de estar em contato com as crianças, fazendo música juntamente a elas, estando com as mesmas ao conduzir e propor o ensino e aprendizagem da música por meio do jogo. Thiollent (1988) analisa os contextos favoráveis para a pesquisaação, indicando tanto o fato de os pesquisadores não estarem satisfeitos com a limitação de suas pesquisas aos aspectos acadêmicos, além do interesse pela participação de outros sujeitos.

Em geral, a ideia de pesquisa-ação encontra um contexto favorável quando os pesquisadores não querem limitar suas investigações aos aspectos acadêmicos e burocráticos da maioria das pesquisas convencionais. Querem pesquisas nas quais as pessoas implicadas tenham algo a "dizer" e a "fazer". Não se trata de simples levantamento de dados ou de relatórios a serem arquivados. Com a pesquisa-ação os pesquisadores pretendem desempenhar um papel ativo na própria realidade dos fatos observados (THIOLLENT, 1988, p. 16). 
Desta forma, por meio da pesquisa-ação, busquei intervir em uma Oficina de Música na Escola de Aplicação da USP, conduzindo as aulas desta Oficina. Acredita-se que este método, ao permitir o envolvimento do pesquisador na elaboração e prática de uma ação, capacite-o também em sua prática profissional.

É, portanto, uma maneira de se fazer pesquisa em situações em que também se é uma pessoa da prática e se deseja melhorar a compreensão desta [...] No entender de Nunan, este tipo de pesquisa constitui um meio de desenvolvimento profissional de 'dentro para fora', pois parte das preocupações e interesses das pessoas envolvidas na prática, envolvendo-as em seu próprio desenvolvimento profissional (ENGEL, 2000, p. 182-183).

A pesquisa-ação tem sido bastante utilizada na área da educação. Na visão de Engel (2000, p. 189), ela é um “instrumento valioso, ao qual os professores podem recorrer com o intuito de melhorarem o processo de ensino-aprendizagem, pelo menos no ambiente em que atuam”.

Por fim, finalizo com a colocação de Thiollent (1988) a respeito das justificativas para a pesquisa-ação na educação. Dentre estas está a desilusão com a metodologia convencional para a educação, que parece trazer resultados distantes em relação aos problemas vivenciados no cotidiano escolar.

Um outro tema amplamente debatido diz respeito ao uso de métodos participativos e ao uso da pesquisa-ação em contexto educacional. Uma das mais difundidas justificativas consiste na constatação de uma desilusão para com a metodologia convencional, cujos resultados, apesar de sua aparente precisão, estão muito afastados dos problemas urgentes da situação atual da educação. Por necessárias que sejam, revelam-se insuficientes muitas das pesquisas que se limitam a uma simples descrição da situação ou a uma avaliação de rendimentos escolares (THIOLLENT, 1988, p. 74).

\subsection{INSTRUMENTOS/MEIOS PARA A COLETA DE DADOS}

Para a coleta de dados na prática da pesquisa-ação em questão fez-se uso das seguintes técnicas: filmagem das aulas, obtendo-se registro audiovisual de todos os encontros realizados; entrevistas semiestruturadas, visando captar a perspectiva das crianças sobre as questões levantadas (dentre outras problemáticas sobre as quais os próprios participantes 
desejassem discorrer); e protocolos de qualquer suporte - relatos escritos, desenhos, colagens, ou quaisquer outros meios de anotações que as crianças optassem por utilizar.

Estes instrumentos para a coleta de dados são bastante frequentes nas pesquisas de abordagem qualitativa, já que o interesse desta abordagem metodológica está na obtenção da perspectiva dos sujeitos participantes da pesquisa (que pode ser captada por meio das entrevistas e protocolos), além de uma rica descrição dos eventos observados (aspecto que se torna possível por meio das filmagens, visto que este meio possibilita rever os episódios vivenciados em sala de aula).

Alguns autores abordam o uso destas técnicas nas pesquisas de abordagem qualitativa, abarcando suas vantagens e desvantagens durante o desenvolvimento do trabalho. Descrevemse a seguir as técnicas de coleta de dados escolhidas no decorrer desta pesquisa-ação.

\subsubsection{Registros audiovisuais}

Considerando-se o enfoque qualitativo desta pesquisa, o contexto da sala de aula (ambiente onde se deram as atuações), o estudo de fenômenos bastante complexos neste contexto - como as relações e interações entre as crianças, além da subjetividade da pesquisa, fez-se necessário o uso de diversos procedimentos para a coleta de dados. A filmagem é um destes meios que permite, no contexto pedagógico, que situações não percebidas em sala pelo investigador possam ser observadas após as aulas. Assim como aponta Visnadi (2013), podese dizer que:

\footnotetext{
Tendo em vista a natureza desta pesquisa, a utilização dos registros em videogravação tornou-se necessária, pois através deste procedimento é possível capturar aspectos difíceis de serem captados com outros recursos, necessários para a posterior análise dos dados (GARCEZ; DUARTE; EISENBERG, 2011). Através do registro em vídeo, expressões corporais, faciais, detalhes de relacionamento entre as crianças, reações face às composições dos colegas, entre outras questões - que podem passar despercebidas ao olho do pesquisador - poderão ser confrontadas, no momento da análise, junto aos dados de outra natureza (VISNADI, 2013, p. 50).
}

A respeito das filmagens, Loizos (2002) também comenta a contribuição do vídeo ao permitir o registro das ações e comportamentos, provendo um maior grau de exatidão nos 
dados coletados. Para além disso, o autor aponta a possibilidade de ver-se e rever-se o mesmo vídeo, repetindo-o quantas vezes forem necessárias durante a análise e interpretação dos dados. Assim sendo, como dito anteriormente, questões despercebidas em um primeiro olhar - no contexto da sala de aula, por exemplo - podem ser percebidas por meio da repetição dos registros audiovisuais.

Fazendo um paralelo com a técnica de observação ao vivo, verifica-se que quando se observa algo pela primeira vez, inicialmente são retidos os aspectos mais impressionantes do observado. Se o comportamento não for visto outras vezes, pontos mais detalhados poderão passar despercebidos. Com o uso do vídeo há um exame aprofundado do processo analisado, pois ele permite ver quantas vezes forem necessárias (REYNA, 1997), o que não acontece somente com a observação. Ao se examinar e interpretar os dados repetidas vezes o pesquisador descobre novas interrogantes, novos caminhos a serem trilhados (LOIZOS, 2002, p. 192-193).

Conforme comentado pelo autor, podemos observar que a filmagem colabora até mesmo com o levantamento de novas problemáticas, pois “a imagem oferece à prática de observação e descrição, um suporte a mais, um novo olhar” (LOIZOS, 2002, p. 193).

Considerando a complexidade do contexto pedagógico, entendo que “o vídeo tem uma função óbvia de registro de dados sempre que algum conjunto de ações humanas é complexo e difícil de ser descrito compreensivamente por um único pesquisador, enquanto ele se desenrola” (LOIZOS, 2002, p. 149). Assim sendo, além das filmagens permitirem a reprodução e repetição dos acontecimentos vivenciados em sala de aula, auxiliando no processo de análise e interpretação dos dados, salienta-se também o fato de o pesquisador poder conduzir suas propostas juntamente à turma com maior tranquilidade, não tendo a necessidade de, simultaneamente, registrar as falas das crianças. Tendo consciência do quão importantes são as falas e opiniões expressas pelas crianças durante a pesquisa, torna-se fundamental o seu armazenamento. Porém, acredita-se ser inviável ao pesquisador a condução das atividades ao mesmo tempo em que se preocupa com a perda de alguma fala, de algum dado importante à pesquisa. Deste modo, as filmagens tornam-se eficazes, na medida em que permitem que o pesquisador volte sua atenção à condução das atividades, ao invés de preocupar-se com anotações simultâneas à condução da aula (já que estas podem ser realizadas, posteriormente, com a visualização e audição dos vídeos). 
As filmagens têm sido bastante utilizadas nas pesquisas da área da educação e, segundo Honorato et al. (2006), as imagens (fotografias) e registros audiovisuais podem auxiliar nas pesquisas com crianças. Como afirmam:

\begin{abstract}
Afinal, como registrar tantos meandros, tantos detalhes, tantas relações para depois debruçar-se sobre? Há ditos que não são pronunciados oralmente; ditos que não são captados por um gravador e acabam perdidos sem um registro... Desta percepção desdobra-se a ideia de que a captação da imagem também pode revelar-se como rica fonte de elementos a serem analisados [...] Posteriormente, a filmagem revela-se como instrumento outro que, ao invés de "congelar" momentos, busca capturá-los de forma diversa - traz som, imagem e movimento integrados, assumindo que a imagem sozinha não cobre tanto o panorama pesquisado, mas pode ser vista/entendida em conjunto com o som e o movimento de forma a favorecer o desvendamento da "intrincada rede que constitui a produção de sentidos" (Macedo et al, 2004, p. 16). Palavra e imagem em movimento fazem, da vídeo-gravação, modos de buscar capturar a essência das narrativas em jogo (HONORATO et al., 2006, p. 6-7).
\end{abstract}

\title{
2.3.2 Entrevistas semiestruturadas
}

Optou-se pelo recurso das entrevistas como meio de acessar as ideias e opiniões das crianças sobre as vivências na Oficina de Música. O objetivo era captar a perspectiva dos participantes da pesquisa (configurando, como já dito, intenção característica da abordagem qualitativa). Este instrumento de coleta de dados, portanto, foi de grande importância.

\footnotetext{
A entrevista na pesquisa qualitativa, ao privilegiar a fala dos atores sociais, permite atingir um nível de compreensão da realidade humana que se torna acessível por meio de discursos, sendo apropriada para investigações cujo objetivo é conhecer como as pessoas percebem o mundo. Em outras palavras, a forma específica de conversação que se estabelece em uma entrevista para fins de pesquisa favorece o acesso direto ou indireto às opiniões, às crenças, aos valores e aos significados que as pessoas atribuem a si, aos outros e ao mundo circundante (CAMURRA; BATISTELA, 2009, p. 5).
}

Em geral, como técnica/procedimento de pesquisa, as entrevistas são classificadas como: (1) estruturadas, (2) semiestruturadas e (3) não estruturadas ou "abertas” (MANZINI, 2004; OLIVEIRA, 2009; OLIVEIRA, 2010). A primeira classificação faz menção àquelas com perguntas pré-definidas, feitas sequencialmente, e sem espaço para intervenção dos entrevistados. As não estruturadas, também chamadas “abertas”, são guiadas pelas falas dos 
entrevistados, não havendo um roteiro de perguntas a serem direcionadas a eles (apesar de alguns autores considerarem que o modelo de entrevista não estruturada pode possuir algumas questões mais abertas, que servirão de guia para o processo). Por fim, o modelo das entrevistas semiestruturadas está entre estes dois extremos: não deixa de ter uma predefinição de perguntas, mas também não se limita a elas. Deste modo, o pesquisador pode elaborar questões, mas estas não são rígidas nem sequenciais; permite-se a intervenção dos entrevistados que, por sua vez, podem delinear novos rumos à entrevista. Segundo Belei et al. (2008, p. 189), “um dos modelos mais utilizados é o da entrevista semiestruturada, guiada pelo roteiro de questões, o qual permite uma organização flexível e ampliação dos questionamentos à medida que as informações vão sendo fornecidas pelo entrevistado”.

Acredita-se que o modelo da entrevista semiestruturada auxilie bastante nas pesquisas que envolvam crianças, permitindo que o investigador indague a respeito de questões fundamentais para a sua pesquisa, mas, também, abrindo espaço para as reflexões das crianças - que muitas vezes não se enquadram em nenhuma das questões predefinidas. Assim sendo, dá-se espaço para as percepções das crianças de forma ampla, não se impondo um limite por meio de uma estrutura rígida de perguntas. Oliveira (2009) expressa também sua opinião a respeito dos tipos de entrevistas nas pesquisas em contexto educacional.

Todos os tipos de entrevistas aqui elencados são possíveis numa pesquisa
educacional. Provavelmente, a entrevista semiestruturada dê uma maior
possibilidade de entendimento das questões estudadas nesse ambiente, uma vez que
permite não somente a realização de perguntas que são necessárias à pesquisa e não
podem ser deixadas de lado, mas também a relativização dessas perguntas, dando
liberdade ao entrevistado e a possibilidade de surgir novos questionamentos não
previstos pelo pesquisador, o que poderá ocasionar uma melhor compreensão do
objeto em questão (OLIVEIRA, 2009, s/p).

Deste modo, optou-se por realizar entrevistas semiestruturadas com as crianças. Cada um dos doze participantes da Oficina de Música foi entrevistado duas vezes: uma vez em grupo (grupos formados por três alunos) e outra, individualmente. As entrevistas em grupo duravam em média 30 minutos e visavam obter informações advindas das crianças a respeito da Oficina de Música, dos jogos vivenciados em sala, das criações dos alunos, bem como da participação e do interesse da turma, dentre outras questões que versavam sobre o contexto 
das aulas e o aprendizado musical. As entrevistas individuais foram conduzidas por outro roteiro de perguntas, que focava, por sua vez, os protocolos realizados por cada participante ${ }^{11}$. Nestas entrevistas, que duravam cerca de 20 minutos, as crianças contavam a respeito de suas anotações escritas, desenhos, explicavam o porquê de seus registros, dentre outros aspectos relacionados aos protocolos individuais.

Tanto as entrevistas em grupos quanto as individuais foram conduzidas por perguntas predefinidas, mas sempre abertas às intervenções das crianças. Percebeu-se que, apesar de um mesmo roteiro, as entrevistas seguiram caminhos diferentes a partir das ideias propostas pelas crianças.

\subsubsection{Protocolos}

Protocolos são registros feitos pelos participantes durante a pesquisa. Consistem em anotações realizadas por eles que podem ser feitas por meio de relatos escritos, desenhos, colagens, dentre outros suportes. Para Japiassu (2003), o protocolo pode ser nomeado de diferentes formas: “é possível referir-se a ele como ‘jornal’, ‘lembrança’, 'memória’ ou ainda 'história’ das coisas que ocorrem na sessão de trabalho” (JAPIASSU, 2003, p. 60).

O protocolo surgiu da abordagem brasileira do jogo teatral (LOMBARDI, 2005), sendo um "procedimento que se tornou parte da prática reflexiva realizada nos trabalhos com jogos” (LOMBARDI, 2005, p. 109). Através dos protocolos, que são discutidos com o grupo durante os encontros, gera-se uma reflexão a respeito das experiências vividas na sala de aula. Pereira (2012), pesquisador que também fez uso deste instrumento de coleta de dados durante a prática de uma pesquisa-ação, afirma que

os protocolos referem-se aos registros individuais - escritos, imagéticos, gestuais ou de qualquer ordem expressiva - dos estudantes a partir das experiências em sala aula e socializados no grupo de trabalho na aula seguinte, no sentido de gerar uma reflexão coletiva que impulsione a aprendizagem (PEREIRA, 2012, p. 40).

\footnotetext{
${ }^{11} \mathrm{O}$ roteiro das entrevistas em grupo e individuais pode ser encontrado nos apêndices deste trabalho.
} 
Os protocolos também servem como meio de ativação da memória (ZANETTA, 2012). Constituindo-se de anotações e reflexões sobre experiências vivenciadas em aulas anteriores, possibilitam ao aluno a lembrança de detalhes que poderiam ser esquecidos. Este aspecto também foi observado na prática desta pesquisa, visto que as crianças comentaram em sala e durante as entrevistas acerca da importância das anotações realizadas, para que elas mesmas pudessem lembrar o que havia sido trabalhado na aula anterior.

Para a prática na Oficina de Música Jogos musicais foram adquiridos doze cadernos de desenho e distribuídos para todos os integrantes da turma. Optou-se pelos cadernos de desenho por terem folhas brancas, sem linhas ou pautas, acreditando que isto traria maior liberdade aos registros das crianças. Esta opção também teve intuito de mostrar aos alunos que as anotações não precisavam consistir de textos escritos, pois muitas crianças, ainda cursando os anos inicias na escola, não sabiam escrever. Percebeu-se, logo no início da Oficina, que esta preocupação esteve presente entre os alunos mais novos. Alguns deles, no primeiro encontro, chamaram a pesquisadora, avisando que não sabiam escrever. Reforçou-se, no entanto, que poderiam fazer o que desejassem (desenhos, pinturas, colagens, etc.), e que justamente por isso as folhas não tinham linhas. Com isso, os alunos se sentiram mais à vontade no registro de suas expressões.

Todos os protocolos confeccionados pelas crianças, portanto, integraram o caderno cedido a cada uma delas. Informou-se que elas poderiam registrar o que quisessem, inclusive, na capa do caderno (que estava sem quaisquer registros). Para algumas crianças, este material se tornou o seu "Caderno de Música”. Observou-se isto por meio das próprias anotações nas capas, onde as crianças colocavam seus nomes e o nome da Oficina. Algumas relataram também, durante as entrevistas, que aquele havia sido o seu primeiro “caderno de música”. Deste modo, os protocolos foram bastante significativos na prática desta pesquisa e uma posterior análise dos mesmos será apresentada no capítulo três deste trabalho.

\subsubsection{Novas ideias para a ampliação da coleta de dados}

No último dia da prática da pesquisa-ação, a pesquisadora e a professora Denise professora de música da escola - conversaram sobre como havia sido a Oficina e a 
participação das crianças. Esta professora esteve acompanhando todas as aulas, participando também dos jogos realizados durante a Oficina. No decorrer da conversa, ela fez diversos comentários a respeito de como percebeu a participação das crianças neste processo. Os relatos feitos por ela foram de fundamental importância, possibilitando compreender ainda mais a maneira na qual algumas crianças se engajaram na pesquisa (além de permitir que se repensassem os meios de coleta de dados, de modo a ampliá-los, mesmo após o término da prática da pesquisa-ação). Tendo em vista que esta professora conhecia alguns dos alunos participantes da Oficina, pois já havia ministrado aulas para alguns deles neste ou em outro ano, ela pôde discorrer acerca do comportamento destas crianças nas outras aulas e na Oficina de Música, fazendo comparações. Os relatos compartilhados pela professora com a pesquisadora no último dia da Oficina focaram o comportamento de dois alunos. Analisando os apontamentos levantados pela professora e a importância destes para o desenvolvimento da pesquisa, resolveu-se ampliar a coleta de dados.

Portanto, tendo em vista a abordagem qualitativa que foi adotada neste trabalho, que prevê a possibilidade de mudanças e intervenções no decorrer do processo, somou-se às técnicas de coleta de dados, uma entrevista que foi realizada com a professora Denise. Inicialmente, previam-se as filmagens, as entrevistas semiestruturadas com as crianças e os protocolos por elas confeccionados. Os dois relatos que serão apresentados no capítulo posterior (voltado à análise dos dados), contanto, demonstram que seria possível ter acesso a dados importantes por meio de conversas com a professora. Assim sendo, o processo de coleta de dados foi ampliado, mesmo após o término da Oficina.

Foi acordado, entre mim e Denise, que uma entrevista seria realizada com a mesma no segundo semestre deste ano, sendo feita via internet ou pessoalmente (dependendo da disponibilidade da professora). Consistiu em uma entrevista semiestruturada, com questões planejadas por mim previamente, mas com espaço para que outras colocações (ainda que não correspondentes às perguntas realizadas) fossem apresentadas pela entrevistada. Desta forma, acreditou-se que outros dados importantes poderiam surgir para análise e (re)interpretação dos dados coletados. 


\subsection{PROCEDIMENTOS ÉTICOS}

Considerando que os dados coletados durante a Oficina de Música seriam publicados, posteriormente, na dissertação de mestrado fruto da pesquisa, foi necessário um pedido de autorização $^{12}$ aos pais ou responsáveis das crianças para utilização destes dados. Dentre estes, figuram as fotografias, filmagens, conversas durante as aulas e entrevistas, além dos registros feitos pelas crianças enquanto protocolos das aulas - em sua maioria relatos escritos ou desenhos. Neste pedido de autorização foi comunicada também a troca dos nomes verdadeiros das crianças por nomes fictícios, mantendo-se assim o anonimato dos participantes da pesquisa. O nome verídico da professora de música da EAFEUSP participante desta pesquisa também foi omitido, utilizando-se um nome fictício.

\subsection{ESCOLA DE APLICAÇÃO DA UNIVERSIDADE DE SÃO PAULO: CONSIDERAÇÕES A RESPEITO DO CAMPO DE ATUAÇÃO}

A Escola de Aplicação da Faculdade de Educação da Universidade de São Paulo (doravante EAFEUSP) tem sua origem na criação de uma classe experimental ligada ao Centro Regional de Pesquisas Educacionais de São Paulo Professor Queiroz Filho (CRPESP). Em decorrência desta classe, criou-se a Escola Experimental, no ano de 1958, "com o objetivo de realizar ensaios de técnicas de ensino, bem como oferecer cursos de aperfeiçoamento para professores, inclusive de outros países, por meio de convênio estabelecido com a UNESCO” (EAFEUSP, 2014, s/p). A Escola Experimental foi reconhecida por suas experiências e diferenciadas propostas pedagógicas. No ano de 1962 passou a chamar-se Escola de Demonstração. Com a extinção do CRPE, vinculou-se à Faculdade de Educação da USP, obtendo o nome atual a partir do ano de 1973. A EAFEUSP

${ }^{12}$ A carta de autorização entregue aos pais por intermédio da coordenadora da escola pode ser visualizada nos apêndices deste trabalho. 
permaneceu "mantendo seu caráter de importante centro para pesquisas na área educacional e espaço privilegiado para estágios de futuros educadores” (EAFEUSP, 2014, s/p).

A escola, situada na Cidade Universitária, atendeu, no último ano, a 736 alunos nos turnos matutino e vespertino, sendo 299 no Ensino Fundamental I ( $1^{\circ}$ ao $5^{\circ}$ ano), 251 no Ensino Fundamental II ( $6^{\circ}$ ano $9^{\circ}$ ano) e 186 alunos no Ensino Médio. A partir dos últimos dados expostos no site da instituição, pode-se afirmar que a escola recebeu 111 estagiários no $1^{\text {o }}$ semestre de 2013. O número de pesquisadores, entretanto, não consta no site.

De acordo com o Regimento da escola, ela se caracteriza como "instância complementar para o ensino, a pesquisa e a extensão universitária” (EAFEUSP, 2014, s/p). Consta, dentre seus objetivos sediar pesquisas, tanto as de interesse da escola quanto as de interesse da Faculdade de Educação, visando aperfeiçoar o processo educativo e a formação docente (EAFEUSP, 2014, s/p).

Para a realização de pesquisas são necessários alguns procedimentos prévios. A pesquisa em questão passou por estes procedimentos, sendo submetida à aprovação pela equipe técnico-pedagógica designada pela escola. Foi necessário o encaminhamento do Projeto de Mestrado, além do preenchimento e envio de documentos e formulários disponíveis no site da instituição. Todos estes documentos foram remetidos ainda no primeiro semestre de 2013, apesar do interesse de realização da Oficina de Música ser apenas para o ano seguinte. Após reunião da equipe técnico-pedagógica, a escola entrou em contato para informar a aprovação do projeto, além de solicitar o agendamento de uma reunião envolvendo professores da área das Artes e a pesquisadora em questão.

A escola conta com a realização de diversas Oficinas todos os anos, dependendo do interesse e disponibilidade de proponentes para existência das mesmas. Assim sendo, em um período designado pela instituição, permite-se apresentar propostas de Oficinas na escola que, por sua vez, oferece aos alunos. Estes últimos recebem uma lista com o nome de todas as Oficinas oferecidas, devendo selecionar suas prioridades. Neste ano, por exemplo, os estudantes receberam uma lista em que, por meio de números, deveriam demonstrar a vontade de participação nas Oficinas listadas (anotando o número “1” ao lado do nome da Oficina pela qual tinham maior interesse; número "2" para uma Oficina em que desejariam participar caso não houvesse mais vagas na primeira selecionada; e assim por diante).

A Oficina Jogos musicais, proposta nesta pesquisa-ação, esteve como possibilidade de escolha dentre diversas outras na lista apresentada às crianças, tais como as oficinas de 
Undokai, Culinária Mexicana, Jardinagem, Francês, Origami, Xadrez, Espanhol, Histórias em quadrinhos, etc. Ela também foi divulgada, igualmente a estas citadas, por meio de cartaz exposto na escola.

\subsubsection{Oficina Jogos Musicais: sua proposta e configuração}

A proposta desta Oficina foi proporcionar uma vivência de jogos de improvisação cênico-musicais, estabelecendo-se um ambiente lúdico para a criação sonoro-musical das crianças. Deste modo, anteriormente ao começo dos encontros, foram planejados, criados e recriados diversos modelos de jogos de improvisação. A intenção era que, com um grande “repertório” de jogos, se pudesse atender às possíveis mudanças sugeridas pelas próprias crianças durante as aulas. Logo, a partir do que elas propusessem em sala, seus interesses, gostos, dentre outros fatores, seria possível variar, modificar e até mesmo trocar os jogos anteriormente escolhidos por outros, que se adaptassem melhor aos interesses do grupo. E assim aconteceu. Em média, apenas metade dos jogos pensados para a Oficina foi realizada. O grupo conduziu e norteou a escolha do que foi sendo trabalhado, modificando a estrutura do “pré-planejamento”. Com isto, o objetivo de que o planejamento fosse delineado a partir da convivência com o grupo se tornou possível, aspecto bastante importante e valorizado nesta pesquisa.

Inicialmente, a Oficina foi pensada para um período de três meses, com encontros semanais. Porém, foi necessário adaptá-la ao tempo cedido pela escola, de dois meses. Os encontros permaneceram semanais, às terças-feiras, com uma hora de duração, das $17 \mathrm{~h}$ às $18 \mathrm{~h}$ (sendo este o espaço de tempo oferecido pela escola, sem possibilidades de alteração).

As aulas começaram no mês de abril, no dia 15, com previsão de término no dia 3 de junho, totalizando oito encontros (ao invés de doze aulas, como previsto anteriormente). Porém, devido à greve na Universidade de São Paulo e consequentes paralisações na escola, a aula do dia 3 de junho não foi realizada. Todas as Oficinas da escola que teriam seu último encontro nesta data foram adiadas para o dia 24 de junho.

A Oficina contou com a participação de 12 crianças. A pesquisadora solicitou à escola, previamente, que a Oficina pudesse contar com o limite de 12 alunos, acreditando-se que a 
análise de dados, a realização de entrevistas com todos os participantes, dentre outras ações pertencentes à pesquisa poderiam ser concretizadas com maior qualidade no espaço de tempo contido neste limite.

Os alunos tinham entre 7 e 10 anos de idade (crianças do $1^{\circ}$ ao $5^{\circ}$ ano ${ }^{13}$ ). Dentre os participantes, três faziam parte do $1^{\circ}$ ano, dois do $2^{\circ}$ ano, dois do $3^{\circ}$ ano, dois do $4^{\circ}$ ano e três do $5^{\circ}$. Enfatizo, entretanto, que os alunos do $1^{\circ}$ ano, por exemplo, não pertenciam à mesma turma, pois a escola conta com mais de uma turma de $1^{\circ}$ ano. Igualmente, os outros participantes, ainda que cursando o mesmo período, nem sempre eram da mesma turma. Seis integrantes eram meninas e seis meninos.

A sala de música da escola foi o espaço físico cedido para as aulas. Esta sala continha muitos instrumentos, dentre eles um piano de armário e diversos tambores. Além de instrumentos levados pela pesquisadora, a professora de música da escola, que acompanhou a prática desta pesquisa-ação, também ofereceu alguns instrumentos musicais pertencentes a ela para a realização desta Oficina.

As aulas iniciaram, quase sempre, com uma conversa a respeito dos protocolos feitos na aula anterior pelas crianças. Cada aluno compartilhava suas anotações, lembranças e momentos mais interessantes da aula antecedente, segundo a opinião deles. Em geral, os 5 ou 10 minutos iniciais das aulas foram destinados a este espaço de comentários e reflexões acerca das vivências da aula anterior. Os 40 minutos seguintes eram pensados para a realização dos jogos. Nos últimos 10 minutos, por fim, confeccionávamos os protocolos da aula em questão. Esta distribuição do tempo, entretanto, não foi realizada igualmente em todos os encontros, não sendo um padrão para se seguir com rigor. Deste modo, caso se percebesse grande interesse das crianças durante a participação nos jogos, permanecia-se jogando para, após, prosseguir com a confecção dos protocolos. Entretanto, os protocolos sempre estiveram presentes, tanto em sua produção nos 5 ou 10 minutos finais de cada aula, quanto no início de cada encontro (quando os comentários sobre os registros realizados eram compartilhados). No último encontro, um maior tempo foi destinado para anotações do grupo, considerando-se que todos os integrantes precisavam encerrar seus protocolos e entregá-los

\footnotetext{
${ }^{13}$ Esta diferença na faixa etária foi bastante positiva para as relações e convivência da turma, aspecto que será comentado na análise dos dados.
} 
para a análise dos dados. Portanto, a distribuição de tempo entre a realização de jogos e a confecção de protocolos não foi rígida, sendo estruturada a partir das percepções da pesquisadora no que se refere ao andamento da aula.

Em um mapeamento geral, pode-se dizer que 4 jogos cênico-musicais, inicialmente, foram vivenciados na Oficina. A partir destes jogos, diversos outros foram criados, modificando-se os modelos iniciais. Foram realizadas 9 variações/adaptações dos jogos “bases”, formando-se novos jogos que, portanto, continham novas regras. Outros 4 jogos foram criados em grupos pelas próprias crianças. Portanto, nos oito encontros vivenciamos um total de 17 modelos diferentes de jogos de improvisação cênico-musicais ${ }^{14}$.

Por fim, as entrevistas que permearam os encontros foram pensadas para realização entre a quinta e oitava aula, também às terças-feiras, anteriormente ao horário da Oficina (além da ida à escola no dia 10 de junho, terça-feira posterior ao término da Oficina, para conclusão das entrevistas com alguns alunos). A proposta elaborada juntamente com uma das coordenadoras da escola sugeria que, durante cinco semanas, entre $14 \mathrm{~h} 20$ e $16 \mathrm{~h} 30$ das terçasfeiras, fossem realizadas uma entrevista em grupo e duas ou três individuais. Este planejamento, aprovado pela escola e pelas professoras das turmas, foi bastante alterado devido à greve, tornando constante a ida da pesquisadora à escola em outras datas. Assim, não apenas um dia da semana foi utilizado, mas quaisquer dias em que não houvesse paralisações e as crianças, portanto, estivessem presentes. O item a seguir destina-se ao desenho metodológico da pesquisa, ilustrando este período de realização das aulas, filmagens, entrevistas e confecção dos protocolos.

\footnotetext{
${ }^{14}$ Estes números foram aqui expressos apenas como forma de registro, além de possível curiosidade do leitor. Nesta pesquisa, entretanto, não houve preocupação com a "quantidade" de jogos que seriam realizados em sala. Fosse um jogo, ou vinte jogos realizados, a preocupação nesta pesquisa esteve em investigar as interações entre os participantes, suas falas e opiniões, pesquisando as contribuições dos jogos para a formação integral das crianças. Portanto, estas expressões numéricas/quantitativas não estão relacionadas com o interesse do trabalho.
} 


\subsubsection{Desenho metodológico da pesquisa}

A partir da proposta da pesquisa-ação, cuja prática foi realizada na Oficina Jogos Musicais na Escola de Aplicação da USP, buscou-se a perspectiva das crianças a respeito das vivências de improvisação em jogos cênico-musicais. Esquematizando a prática desta pesquisa e o delineamento da mesma, pensou-se que as oito aulas com as crianças seriam permeadas pelos registros audiovisuais e pelos protocolos. Logo, ambas as técnicas de coleta de dados estiveram presentes em todos os encontros (meses de abril, maio e junho). As entrevistas em grupos e individuais, por sua vez, ocorreram a partir do mês de maio, tendo continuidade até o término das aulas. Para fins de ilustração, segue abaixo o desenho metodológico desta pesquisa.

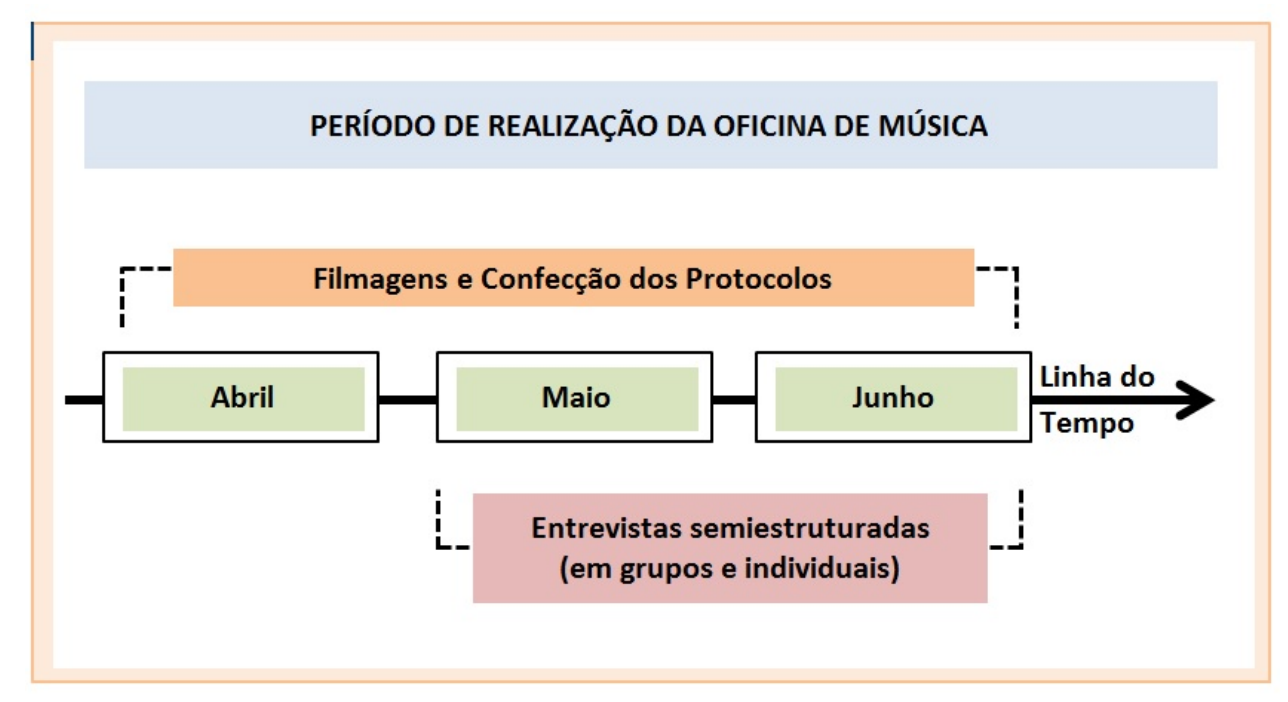

Figura 1 - Desenho metodológico

\subsection{DESCRIÇÃO DOS JOGOS}

Serão descritos neste item os jogos que foram trabalhados na Oficina de Música, explicando-se o funcionamento dos mesmos. Vale ressaltar que diversos outros jogos foram 
pensados para os encontros realizados. Entretanto, a partir do desejo e interesse dos alunos, foi-se escolhendo aqueles que se tornariam efetivos e significativos aos mesmos para vivência em sala de aula.

As próprias crianças participaram de tais decisões. Um exemplo disso foi o comentário feito aos alunos acerca da possibilidade de dar-se prosseguimento aos encontros com outros jogos conhecidos pela pesquisadora, com jogos conhecidos por eles ou, ainda, com um momento para que eles criassem, em grupos, novos jogos. Eles optaram pela última sugestão e, assim, as aulas seguintes foram conduzidas e delineadas por tal escolha. Igualmente, em diversos momentos os alunos proferiram seus gostos, expondo, dentre outras ideias, que gostariam de usar os instrumentos livremente, que desejavam criar composições, que tinham interesse em repetir algum jogo já realizado ou assistir novamente um exemplo audiovisual trabalhado em sala, etc. A partir destes apontamentos, a pesquisadora escolheu outros jogos, delineando o trabalho em sala de aula de acordo com as vontades das crianças.

Apenas ao término da prática da pesquisa-ação, portanto, a pesquisadora esteve certa a respeito de quais jogos seriam descritos neste trabalho: aqueles escolhidos e vivenciados em sala, seguindo-se os interesses das crianças. Estes jogos serão apresentados na tabela abaixo e, posteriormente, será descrito o funcionamento dos mesmos.

\begin{tabular}{|l|l|}
\hline \multicolumn{1}{|c|}{ Jogo } & \multicolumn{1}{c|}{ Resumo das ações / Objetivos } \\
\hline Jogo dos nomes: relógio maluco & $\begin{array}{l}\text { Aprender os nomes dos integrantes da } \\
\text { Oficina; trabalhar, ainda que de forma } \\
\text { simples, alguns aspectos de improvisação }\end{array}$ \\
\hline Pega-congela sonoro & $\begin{array}{l}\text { "Distribuir”, reproduzir e criar sons, } \\
\text { explorando sonoridades durante o jogo; } \\
\text { interagir com as ações provocadas pelo } \\
\text { "pegador” e "salvador" }\end{array}$ \\
\hline Floresta e seus bichos & \begin{tabular}{l} 
Sonorizar o ambiente de uma floresta (nas \\
\hline
\end{tabular} \\
\hline
\end{tabular}




\begin{tabular}{|c|c|}
\hline & $\begin{array}{l}\text { diversas “fases” estabelecidas), por meio } \\
\text { de uma improvisação livre; reger uma } \\
\text { improvisação ao trabalhar com as ideias } \\
\text { de retirar ou colocar sons }\end{array}$ \\
\hline Jogo com canção Monjolo & $\begin{array}{l}\text { Aprender a canção; improvisar com } \\
\text { instrumentos não convencionais }\end{array}$ \\
\hline Criação 1 - Pega-pega animal & $\begin{array}{l}\text { Criar sons de animais ao ser “salvo” } \\
\text { durante o jogo, assim como responder } \\
\text { corporalmente quando for “pego” }\end{array}$ \\
\hline Criação 2 - Música & $\begin{array}{l}\text { Investigar quem é o “caçador” dos } \\
\text { “animais”, buscando descobrir por meio } \\
\text { do som emitido no disparo de sua flecha }\end{array}$ \\
\hline Criação 3 - Detetive & $\begin{array}{l}\text { Emitir sons e fazer com que o grupo os } \\
\text { reproduza sem que o “detetive”, externo à } \\
\text { roda, descubra quem inicia a produção } \\
\text { sonora }\end{array}$ \\
\hline Criação 4 - Competição de instrumentos & $\begin{array}{l}\text { Criar composições em grupo e apresentá- } \\
\text { las à turma, de modo que o “juiz” } \\
\text { determine a composição vencedora da } \\
\text { competição }\end{array}$ \\
\hline
\end{tabular}

\subsubsection{Jogo dos nomes: relógio maluco}


Este jogo propicia um momento para o aprendizado dos nomes de todos os integrantes da Oficina. Inicialmente, deve-se pensar no funcionamento de um relógio de parede, cujo ponteiro, de hora em hora, aponta para um novo número. Forma-se uma roda na qual cada jogador se posicionará, imaginando-se no lugar de um número do relógio. Em sentido horário, um jogador por vez deve falar seu nome. Repete-se este primeiro momento (de apresentação dos nomes) o número de vezes que for preciso, de acordo com que os jogadores desejarem.

O segundo momento (fase) do jogo é caracterizado pelo fato do jogador não mais proferir seu nome, e sim o nome da pessoa que estiver à sua esquerda (sentido horário). Assim, o jogador que estiver representando o número 1 do relógio deve dizer o nome do jogador que ocupa a posição do número 2. O “número 2”, por sua vez, pronuncia o nome do “número 3”, e assim por diante. Igualmente à fase um, repete-se este momento quantas vezes for necessário. Pode-se, ainda, variar esta fase, pedindo-se que os jogadores pronunciem o nome do integrante que estiver à sua direita (sentido anti-horário).

Na terceira fase, a ordem sequencial dos números do relógio desaparece. Ou seja: os jogadores não irão mais proferir o nome dos que estão à sua esquerda ou direita, mas haverá uma “desordem” no funcionamento do relógio. Desta maneira, o “número 1” deverá escolher se deseja falar o nome do jogador que representa o número 2 (sentido horário) ou do jogador de número 12 (sentido anti-horário). Caso, por exemplo, escolha o "número 2", este último optará entre o “número 3” (sentido horário) ou retornar ao “número 1” (sentido anti-horário). Isto significa que cada jogador poderá escolher entre quaisquer dos dois jogadores que estiverem ao seu lado na roda. Assim, um elemento de improvisação (e incerteza) é inserido: nenhum integrante estará certo de como o jogo irá desencadear. Não se sabe, por exemplo, se o jogador 2 escolherá o 3 ou o 1 para dar prosseguimento ao jogo, assim como os jogadores 3 e 1 não têm certeza se serão chamados. Todos os integrantes sabem, apenas, que no momento que um determinado jogador pronunciar algum nome, poderá escolher dentre os nomes dos dois jogadores posicionados ao seu lado.

Na quarta fase, os aspectos do improviso e da incerteza serão mais trabalhados. Neste momento, os jogadores poderão chamar pelo participante que desejarem. Isto significa que não haverá mais ordem ou sequência alguma. O jogador 1, por exemplo, pode chamar pelo jogador 7, 2, 5... Logo, todos os jogadores em cena precisam estar atentos a todo instante, sabendo que existe a possibilidade de serem chamados a qualquer momento e, portanto, de darem continuidade ao jogo. 
Em cada uma das fases há a possibilidade de inserção de outro elemento: o pulso. Seja na fase 1 ou na fase 4, por exemplo, pode-se trabalhar com a ideia de pulso e andamento/velocidade. Portanto, para trazer maior complexidade ao jogo, os próprios nomes (na fase 1) devem ser pronunciados respeitando-se o pulso, assim como o nome do jogador ao lado (na fase 2), dos jogadores ao lado (na fase 3) e de quaisquer jogadores (na fase 4). A velocidade com que este pulso está sendo marcado pode também ser alterada. Deste modo, os jogadores precisarão lembrar e pronunciar o nome de outro jogador em um andamento lento ou rápido, por exemplo.

Dinâmica e timbre consistem em outros dois elementos possíveis de serem adicionados ao jogo em quaisquer fases. Assim, no momento de se pronunciar um nome (seja o seu ou de outro jogador), exploram-se sonoridades: brinca-se com a dinâmica ao gritar ou cochichar determinado nome; trabalha-se com diferentes “vozes”, imitações, etc., explorandose questões timbrísticas.

A cargo do coordenador e/ou dos jogadores, outros elementos podem ser inseridos, assim como a criação de novas fases através de variações do jogo.

\subsubsection{Pega-congela sonoro}

Este jogo possibilita criar sons que serão reproduzidos e imitados pelo grupo. A estrutura base do jogo é o "pega-pega” ou "pique” - jogo conhecido universalmente (PEREIRA, 2012, p. 157) - constituído pelos personagens “pegador” ou “caçador” e “perseguidos” ou "fugitivos". Enquanto diversos jogadores correm, um integrante tenta pegar todos os outros do grupo. Esta forma padrão também é conhecida por “rela-rela”.

São muitas as variações que podem ser realizadas apenas mexendo-se nesta estrutura inicial, dentre as quais destaco: (1) Pode haver, por exemplo, mais de um pegador em cena; (2) os perseguidos, à medida que são pegos, podem ajudar o(s) pegador(es), compondo-se o chamado pique-ajuda; (3) o pique-ajuda pode variar, formando o pique-corrente, em que os perseguidos pegos devem dar as mãos ao pegador e sair à caça com ele; (4) os perseguidos, quando pegos, também podem congelar, ficar estátuas, formando a variação conhecida por “estátua” ou "pega-gelo”; (5) os jogadores que forem pegos podem encontrar maneiras de se 
salvarem ou serem salvos; compondo outras inúmeras variações (em algumas delas, por exemplo, há um local, uma ação ou uma posição anteriormente designada que possibilita “proteção” aos perseguidos. Este local/ação/posição é chamado de “pique”. Assim, de acordo com o pique combinado, quando um perseguido senta em um banco, encosta em uma árvore ou ajoelha, por exemplo, significa que ele está imune ao pegador); (6) com a troca de pegador no decorrer do jogo: quem for pego deixa de ser perseguido e vira pegador.

Na Oficina de Música trabalhamos com o formato conhecido como "pega-congela" (ou estátua), variando-o também ao inserir elementos sonoros. O funcionamento desta variação do jogo transcorre da seguinte maneira: um jogador é designado “pegador” enquanto os outros compõem os "perseguidos". O pegador deve escolher um som para reproduzir e “carregar” consigo durante o jogo. Este som, antes que se inicie o jogo, precisa ser mostrado/emitido para a turma, para que possa ser "testada” sua reprodução/imitação, garantindo que todos consigam realizá-lo (alguns alunos da Oficina de Música, por exemplo, não conseguiam estalar os dedos. Logo, o som de estalo não pôde ser escolhido pelo pegador).

Enquanto corre para imobilizar/congelar os outros alunos, o pegador precisa manter a emissão do som selecionado. Um jogador pego, por sua vez, deve parar/congelar e reproduzir o mesmo som do pegador. Esta primeira fase do jogo encerra quando todos forem pegos e estiverem parados, reproduzindo o mesmo som que o pegador produzia. Trabalhou-se também com a ideia de um pega-pega “contágio”, imaginando-se que o pegador “contagiaria” a todos com seu som.

Para a segunda fase do jogo foi realizada uma mudança no número de pegadores. Inserindo-se 2 pegadores, cada qual “dono” de um som, os perseguidos precisam estar atentos ao pegador que os pegará. Ou seja: aquele que for imobilizado pelo pegador “A”, deve reproduzir o som do “A”. Aqueles que forem pegos pelo B, devem reproduzir o som do B. Ao fim do jogo, todos estarão imóveis, apenas reproduzindo/ouvindo uma "massa sonora" formada por dois sons diferentes.

A terceira fase/variação proposta consiste em um pega-congela com "pegadores ocultos”. Isto significa, portanto, que a turma desconhece quem serão os pegadores. O coordenador (que pode ser o professor ou uma criança) é o responsável por solicitar que todos fechem os olhos. Em seguida, ele deve encostar em duas pessoas, designando-as “pegadores”. Cada um dos pegadores será responsável por um som. Sem que os outros jogadores saibam quem são estes pegadores e quais foram os sons escolhidos por eles, o jogo se inicia. Os 
perseguidos devem correr para não serem pegos. O jogo termina quando todos forem pegos e estiverem reproduzindo o som do pegador pelo qual foi imobilizado.

A quarta fase foi nomeada pega-congela com "pegador mudo”. O pegador, nesta variação, já não é mais responsável por criar e “transmitir/contagiar” os perseguidos com seu som. Ao invés disso, deve correr sem emitir som algum. Por sua vez, cada perseguido, à medida que for pego, deverá criar/emitir um som. Cada novo jogador pego precisará estar atento aos sons já emitidos pelos perseguidos pegos, para que se possa criar um som diferente dos outros que estiverem sendo reproduzidos na sala. Encerra-se o jogo quando todos os perseguidos forem pegos.

\subsubsection{Floresta e seus bichos}

Este jogo consiste na prática de uma improvisação livre, que se desenvolve a partir da ideia de criar o ambiente sonoro de uma floresta em sala de aula ${ }^{15}$. Para fins de delineamento, sugere-se um acordo mútuo com o grupo acerca de “como” essa floresta pode ser representada. Na Oficina de Música, por exemplo, as crianças representaram “fases” de uma floresta: o seu amanhecer, em que calmaria e tranquilidade estariam presentes; o entardecer, caracterizado por uma forte chuva, trovoadas, etc.; e o anoitecer, em que a "bonança” após a tempestade se faria presente. Musicalmente, pensou-se um mapeamento de momentos de intensidades diferentes: fraco-forte-fraco. Após este acordo, divide-se a turma em jogadores e plateia.

A plateia ficará de costas e/ou estará vendada. Os jogadores deverão escolher, livremente, os instrumentos que usarão para a criação sonora. Disponibiliza-se tempo, também, para que eles possam explorar os instrumentos selecionados, familiarizando-se com as possibilidades sonoras e recursos de determinado instrumento. Em relação à disposição do grupo, pode-se fazer o jogo em roda (com a plateia do lado de fora e de costas para a mesma)

\footnotetext{
${ }^{15}$ É possível criar também um cenário em sala, pedindo que os alunos tragam, por exemplo, galhos e folhas de árvore, dentre outros materiais, para reproduzir o ambiente da floresta também visualmente. Estes materiais, inclusive, podem ser usados para produção sonora no decorrer da improvisação.
} 
ou com os jogadores andando livremente pela sala (neste caso, é necessário que a plateia esteja vendada). Após tais decisões tomadas, a improvisação poderá iniciar. Não há certezas a respeito de como, quando e quem começará a improvisação, assim como não se sabe acerca de seu final. Logo, a duração deste jogo é imprevisível, podendo ocupar poucos ou muitos minutos da aula. O coordenador não deve estar preocupado com esta questão, deixando que os jogadores explorem sonoridades e criem enquanto desejarem.

A primeira variação pensada - formando a segunda fase do jogo - consiste na entrada de “animais” na floresta. Cada jogador deverá permanecer sonorizando uma floresta, por meio dos instrumentos escolhidos, nos momentos do amanhecer e anoitecer. O entardecer, que anteriormente era representado por uma forte tempestade, permanecerá sendo a parte de intensidade forte da peça, entretanto, deverá agora ser representado por um alvoroço entre os animais da floresta, com os sons dos animais substituindo os sons dos instrumentos (ou fazendo-se ambos simultaneamente). Logo, cada aluno escolherá o animal que representará, cabendo aos jogadores um tempo para que explorem estes sons antes do início do jogo. Após, a improvisação livre se iniciará. O primeiro momento, de intensidade fraca, ficará a cargo das sonorizações por meio de instrumentos; o segundo momento, de intensidade forte, deve ser representado pelos sons dos bichos (com sons vocais); e o terceiro momento abrange o retorno aos instrumentos e a calmaria da floresta.

A segunda variação consiste na entrada do “caçador”. Este personagem deve esperar que o grupo inicie a improvisação livre por meio dos instrumentos. Chegando à parte forte da peça, todos os “animais” estarão improvisando. O caçador deve esperar que todos estejam reproduzindo os seus dos bichos escolhidos para, após, sair à caça. Simbolicamente, o caçador deve soltar suas flechas, uma por vez, no animal que deseja "matar"/retirar do jogo. O “animal”, quando “morto”, deve parar de emitir sons (interrompendo sua improvisação). O jogo termina quando todos os animais forem retirados de cena e, por fim, não houver mais sons de bichos. A atuação do caçador, neste jogo, pode ser comparada a de um regente: ele estará no comando, retirando, da improvisação, os sons que desejar.

A quarta fase (variando-se o jogo pela terceira vez) é caracterizada pela entrada do “ativista”. O jogo transcorre como na fase anterior. Porém, assim como o caçador tem autoridade para retirar os animais de cena, o ativista terá o direito de recolocá-los. O caçador permanece a usufruir de sua flecha simbólica: assim que a atira, o animal para de emitir seu som. O ativista, em contrapartida, deverá escolher aqueles que deseja ouvir novamente. Para 
tal, bastará encostar em determinado jogador e ele voltará a improvisar. Portanto, tanto o caçador quanto o ativista dividem, agora, a "regência” da peça. O jogo encerra quando todos os animais forem retirados de cena.

É interessante conversar em sala a respeito da atuação destas duas personagens no jogo (caçador e ativista). Por usufruírem de autoridade acerca dos sons que serão ou não emitidos, eles precisarão estabelecer um diálogo: nenhum poderá agir sozinho. Sem esta conversa poderá acontecer, por exemplo, dos jogadores entrarem em um "ciclo" de disputa, em que o caçador tira um determinado animal e, em seguida, o ativista o coloca em cena. $\mathrm{O}$ caçador tira-o novamente, e o ativista recoloca-o. E assim por diante... O coordenador do jogo deve se manifestar explicando o interesse sonoro da atuação. O interessante não está em uma disputa - tirando-se e colocando-se animais em seguida um do outro - mas sim no resultado sonoro. Então, torna-se importante escutar! O fato dos animais saírem de cena precisa ser compreendido como parte do jogo. Não caberá ao ativista, portanto, “correr” na tentativa de encostar em todos os bichos e recoloca-los em ação. É preciso deixar que alguns animais saiam e que outros surjam conforme se sente falta do som daquele bicho: o interesse deve estar na sonoridade da improvisação, e não em uma disputa.

Ao término de cada fase do jogo, deve-se perguntar à plateia a sua opinião acerca da improvisação. Torna-se muito interessante este momento de debate, em que a plateia poderá descrever o que ouviu, expor quais as sensações/impressões causadas pela improvisação, relatar como foi estar de olhos fechados/vendados, etc.

Outro ponto de extrema importância neste jogo é a alternância entre o grupo de jogadores e o grupo que forma a plateia. Esta troca é fundamental, tendo em vista a possibilidade de cada aluno experimentar ambos papeis (jogador e plateia), assim como uma maneira de se evitar o cansaço das crianças - ocasionado por longo tempo jogando ou pelo longo tempo em que estarão de olhos vendados na plateia.

Por fim, destaca-se ainda a participação dos alunos na transformação deste jogo. Podese pedir que eles criem variações, sugerindo mudanças nas regras do jogo, a retirada de personagens, o acréscimo/invenção de novas personagens, etc.

\subsubsection{Jogo com a canção Bate o Monjolo}


Para trabalhar o jogo a ser descrito posteriormente, o grupo deve conhecer a canção "Bate o monjolo" 16 , cuja melodia e letra encontram-se na partitura abaixo.

\section{Bate o monjolo}

Brinquedo cantado | tradicional
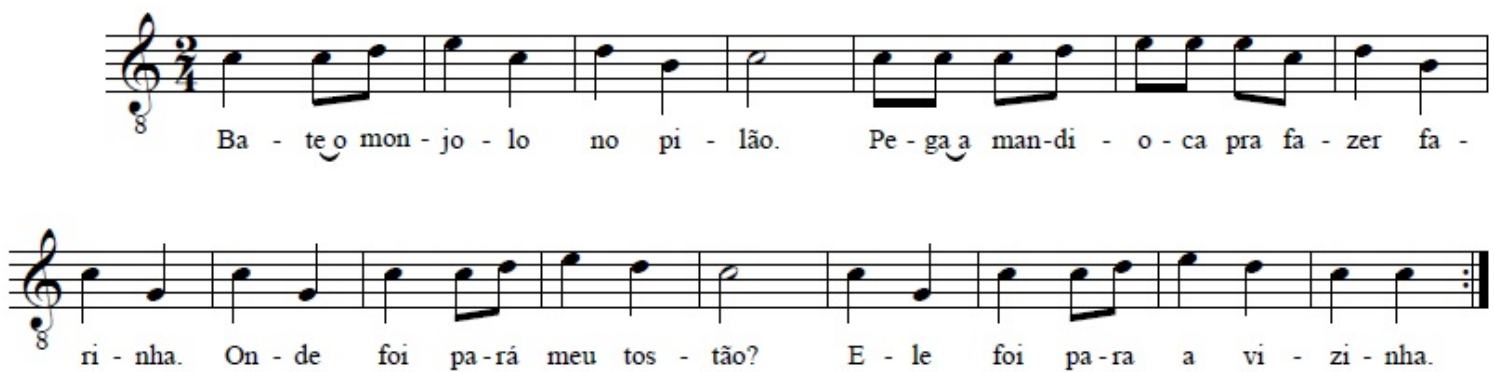

Figura 2 - Partitura da canção Bate o monjolo.

Uma brincadeira cantada também pode ser realizada, utilizando-se uma moeda. Os participantes devem se posicionar em uma roda, sentados, e escolher alguém para ficar no centro do círculo (ou ao lado de fora). Os que estarão em roda colocarão a mão esquerda, com a palma aberta e virada para cima, sobre a mão direita do participante que está sentado ao lado esquerdo. A mão direita, por sua vez, irá se mover de um lado para o outro no formato de uma pinça, fazendo-se alusão ao movimento de bater do pilão. A canção deverá ser entoada juntamente ao movimento das mãos: todos os alunos estarão cantando e, simultaneamente, realizando o movimento da pinça com a mão direita. Este movimento, entretanto, não será apenas para imitar o pilão, mas também para que uma moeda seja repassada entre os participantes que estarão sentados. O grupo precisará combinar o número de vezes que repetirá a canção, transmitindo a moeda uns aos outros enquanto ela perdurar. Ao término da canção, o aluno que estiver no centro (ou fora) da roda deverá adivinhar com quem está a

\footnotetext{
${ }^{16}$ Bate o Monjolo - (MG). Informado por Viviane Beineke. No caso da prática na Oficina de Música, em que a turma ainda não conhecia esta canção, foi preciso ensiná-la (uma frase melódica era cantada pela professora e, em sequência, repetida pelo grupo. Isto foi feito com as quatro frases da canção. Após, a canção inteira foi cantada duas vezes, para que se firmassem a letra e a melodia).
} 
moeda. Na Oficina de Música, por exemplo, foi combinado que caso este aluno acertasse, ele tomaria o lugar da pessoa que estava sentada na roda (com quem estava a moeda). Porém, caso não adivinhasse, a brincadeira daria prosseguimento até que em outro momento ele conseguisse descobrir/encontrar a moeda.

Em seguida ao aprendizado da canção (e à possível brincadeira exposta acima), dá-se início ao aprendizado do acompanhamento rítmico, que será feito por meio de um "jogo de $\operatorname{copos}{ }^{17}$. Para tal, distribuem-se copos plásticos ${ }^{18}$ à turma que poderá, inicialmente, explorar possíveis sonoridades deste material. Dando-se continuidade, o acompanhamento rítmico deve ser trabalhado.

${ }^{17} \mathrm{O}$ acompanhamento rítmico trabalhado, através do jogo de copos, encontra-se no livro Lenga la lenga, de autoria de Viviane Beineke e Sérgio Ribeiro de Freitas (2006). Na Oficina de Música, entretanto, foram feitas algumas variações no manuseio dos copos. Na figura 3 é possível visualizar como foi realizado o acompanhamento rítmico na Oficina.

${ }^{18}$ Estes copos plásticos devem ser duráveis, de material mais resistente que os copos plásticos descartáveis. 


\section{Bate o monjolo}
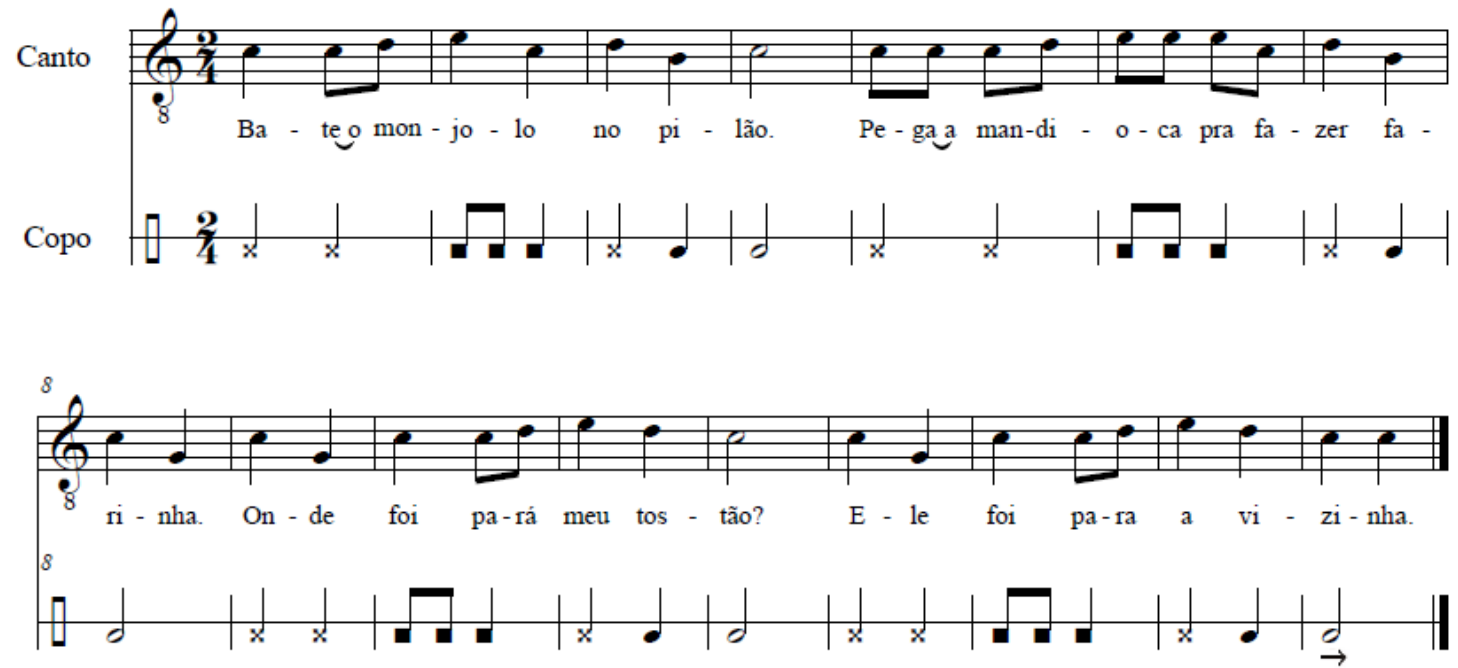

\section{Legenda:}

$\times \quad$ Bater palma

- Bater as mãos (alternadamente) no chão

- Levantar o copo

- Bater a boca do copo no chão

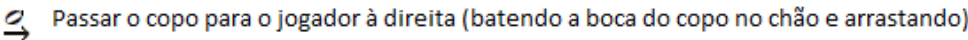

Figura 3 - Partitura de "Bate o monjolo" com ambas as vozes: melodia cantada e acompanhamento rítmico dos copos. 
Assim que todo o grupo aprender o acompanhamento com os copos, algumas ideias de arranjo podem ser cogitadas. Na Oficina de Música, por exemplo, combinamos uma introdução formada pela parte rítmica dos copos, sendo que esta seria reproduzida duas vezes (ocupando-se 8 compassos) antes do início da canção. Após, a canção deveria ser entoada duas vezes por completo e, assim, encerrava-se a música.

Pequenos e/ou longos arranjos podem ser trabalhados. Neste momento, é interessante que o coordenador abra espaço para que as crianças deem sugestões. Logo, pode-se trabalhar com a proposta de que cada aluno apresente sua ideia para o arranjo da canção, com toda a turma experimentando-o, ou, ainda, com uma divisão da turma em grupos, em que cada grupo, por exemplo, cria um arranjo para a peça e, após, expõe e ensina aos demais alunos. O importante é que se abra este espaço para as criações advindas das próprias crianças.

Prossegue-se com uma abertura aos improvisos. Deste modo, a canção agora receberá um novo formato, dando-se espaço para os improvisos que serão realizados individualmente. Na Oficina de Música combinamos a seguinte estrutura para este momento: sentados, formando-se uma roda, deveríamos entoar a canção inteira (16 compassos), coletivamente, reproduzindo tanto a melodia cantada quanto o acompanhamento dos copos. Após, um aluno seria responsável por improvisar, utilizando seu copo. O tempo total do improviso deveria ocupar o correspondente a 4 compassos da canção. Ao término do improviso, toda a turma precisaria retornar ao tutti (inclusive o jogador que improvisou), cantando a música e realizando o acompanhamento por meio dos copos. Após os 16 compassos - correspondendo ao término da canção - o aluno sentado à direita do que improvisou anteriormente será o responsável pela execução da próxima improvisação. Deste modo, portanto, transcorreria o jogo: um tutti que ocupa 16 compassos, seguido de um improviso solo que ocupa 4 compassos. Encerra-se quando todos os participantes tiverem improvisado.

O jogo cênico-musical proposto trabalha com junções e variações de todos os estágios até então apresentados, além da inserção de novos elementos. Sugere-se que os jogadores se posicionem, sentados, formando uma roda. Distribuem-se os copos plásticos a estes. Os jogadores que estarão em roda decidirão qual deles ficará fora da roda, de costas para o grupo. Após tal escolha, o coordenador deve explicar que o jogador fora da roda será o pirata (ou detetive). O pirata estará em busca do tesouro (uma moeda/tostão) que estará protegido por um dos integrantes da roda. Caso se opte pelo detetive, pode-se explicar que se 
trata de uma personagem que está em meio a uma investigação, procurando encontrar quem capturou a moeda. O pirata/detetive deverá, então, ficar de costas para os jogadores da roda. Enquanto isso, uma moeda é dada a um destes. Aquele que receber a moeda deverá escondêla consigo (guardar em algum bolso de sua roupa, sentar em cima da moeda, etc.). Com a moeda escondida, o pirata/detetive poderá virar e começar a observar os jogadores. Estes, por sua vez, começarão a cantar a canção aprendida (Bate o Monjolo), executando também o acompanhamento rítmico com os copos. A última frase da canção, entretanto, não deve ser entoada pelo grupo, mas sim pelo pirata/detetive. Ele será responsável por cantar tal frase, substituindo, entretanto, a palavra “vizinha” presente na canção pelo nome de um dos jogadores da roda com quem ele acha que está a moeda. Desta forma, caso o pirata/detetive acredite que a moeda/o tostão está com o aluno "Maurício”, deverá cantar: “ele foi para o Maurício”.

Os jogadores que estarão sentados, em roda, deverão ficar em silêncio durante esta última frase da música, ouvindo-a atentamente, pois precisarão reagir a ela. Caso o pirata tenha adivinhado ao falar que a moeda estava com o aluno Maurício, por exemplo, este aluno deverá assumir o lugar do pirata, retirando-se da roda. Entretanto, caso Maurício não seja o guardião da moeda, ele deverá responder com um improviso individual, em 4 compassos, através de seu copo. Após, o jogo continua e todos os jogadores voltam a reproduzir a canção. O jogo, portanto, transcorre desta maneira: a canção é entoada coletivamente, sendo que a última frase será sempre solada pelo pirata. Até que ele adivinhe com quem está a moeda, permanecerá como pirata. Enquanto isso, cada jogador chamado pelo nome deverá ter respondido com um improviso, “avisando” que não representava o guardião da moeda. Deixase de ser pirata quando o guardião é encontrado, e este último, então, assume a personagem do primeiro. O jogo pode ser repetido quantas vezes forem desejadas pelo grupo.

\subsubsection{Criação 1 - Pega-pega animal ${ }^{19}$}

\footnotetext{
${ }^{19}$ Jogo criado pelas alunas Fernanda, Gabriela e Larissa.
} 
Este jogo (assim como os próximos três que serão apresentados) é resultante de uma criação em grupo ${ }^{20}$. Todos os alunos, durante um dos encontros da Oficina de Música, estiveram engajados em criar seus próprios jogos. Para isso, solicitou-se a formação de quatro grupos, com a média de três alunos em cada. Os próprios alunos foram responsáveis por decidir com quem trabalhariam. Após algumas conversas, formaram-se os quatro grupos solicitados - dois grupos com 3 alunos em cada, um grupo composto por 4 alunos e outro formado por 2 alunos.

“Pega-pega animal” foi o primeiro jogo concluído e experimentado pela turma. Tratase de uma variação do “pega-pega” - mais uma possível variação dentre as diversas já elencadas neste trabalho. No jogo criado, há duas personagens principais: o "pegador” e o “salvador”. Antes de se dar início ao jogo, faz-se necessário escolher quem representará as personagens apresentadas. Na Oficina de Música, decidiu-se que o grupo criador do jogo seria o responsável por escolher quais alunos da turma representariam as personagens de seu jogo.

O funcionamento se dá da seguinte maneira: o pegador, como de costume, deverá correr atrás dos perseguidos. Estes, por sua vez, deverão estar atentos caso sejam pegos, pois precisarão responder com uma ação corpórea: se o pegador encostar na perna de um perseguido, este último deve andar “saltitando” em uma perna só; caso encoste em um braço, deve colocar um braço para trás e continuar andando apenas com o outro braço em movimento; caso toque nas duas pernas, o perseguido deverá sentar-se. Desta forma, o pegador interage com os perseguidos à medida que encosta na(s) perna(s) ou no(s) braço(s).

O salvador, como o próprio nome denota, é responsável por “salvar” aqueles que foram pegos. Estes, assim que forem salvos, devem emitir o som de um animal, repetindo-o três vezes. Apenas após reproduzirem o som de um animal é que poderão voltar a se locomover normalmente pela sala - isso até serem pegos novamente, precisando retornar a sentar, andar em uma perna só, etc.

O jogo, por si só, não tem fim, tendo em vista que se fecha em torno de um ciclo: jogadores sendo pegos e, após, sendo salvos. Portanto, concluirá quando o grupo desejar.

\footnotetext{
${ }^{20}$ Abaixo da descrição de cada jogo criado pelas crianças, constam as anotações feitas por elas em sala de aula. Os nomes das crianças, entretanto, foram omitidos destes registros para fins de anonimato.
} 
Na figura abaixo, algumas anotações feitas pelas crianças criadoras deste jogo podem ser visualizadas ${ }^{21}$.

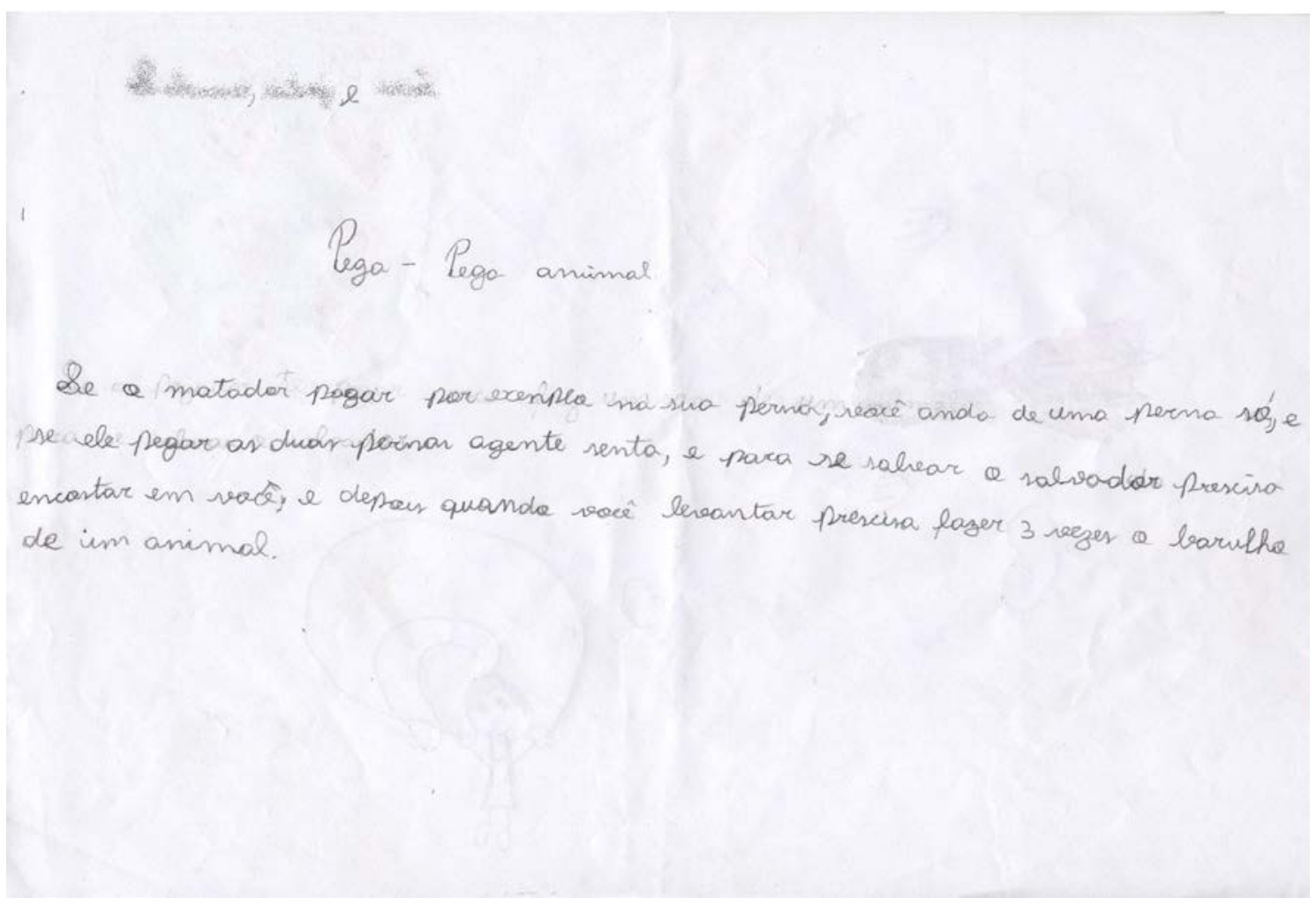

Figura 4 - Anotações referentes ao jogo Pega-pega animal.

\subsubsection{Criação 2 - Música ${ }^{22}$}

"Música” trata-se de um jogo com duas personagens principais: o "detetive” e o “caçador”. Os outros jogadores, por sua vez, representarão "bichos”. Nesta criação, o detetive

\footnotetext{
${ }^{21}$ Transcrição da figura 4: "Pega-pega animal. Se o matador pegar por exemplo na sua perna, você anda de uma perna só, e se ele pegar as duas pernas a gente senta, e para se salvar o salvador precisa encostar em você, e depois quando você levantar precisa fazer 3 vezes o barulho de um animal.”

${ }^{22}$ Jogo criado pelos alunos Luana, Patrícia e Pedro.
} 
é responsável por desvendar, ainda que de olhos fechados, quem está representando o caçador, personagem que emitirá um forte som ao matar cada bicho em cena.

Transcorre da seguinte maneira: após a escolha de quem representará o detetive (decisão que, na Oficina de Música, esteve a cargo do grupo criador deste jogo), tal personagem deverá ser vendado (ou precisará ficar de costas para a turma e de olhos fechados). Assim que o detetive tomar sua posição e estiver sem visualização dos outros jogadores, decide-se quem será o caçador. Este deve ser avisado que assumirá tal papel sem que o detetive saiba desta escolha. Os outros jogadores atuarão como bichos, independente do animal que cada um deseje representar. Faz-se necessário, entretanto, que cada jogador escolha um bicho cujo som consiga imitar/reproduzir.

O jogo começa com os diversos bichos andando, correndo, pulando, movimentando-se pela sala e emitindo seus sons. Quando todos os bichos estiverem em cena, o caçador iniciará sua ação, eliminando cada um deles ao disparar uma flecha imaginária. Ao disparo de cada flecha, entretanto, deve-se emitir um forte som: som que precisa ser ouvido por todos os animais e, principalmente, pelo detetive - personagem responsável por reconhecer o caçador justamente pelo som que ele emitirá durante a caça. Logo, embora o caçador tenha autonomia para criar/inventar o som de sua flecha, deverá ter também consciência da necessidade de uma forte reprodução/entoação, permitindo que seja ouvido pelo detetive. O animal que receber uma flechada deverá sentar ou deitar-se no chão, parando a reprodução de seu som.

Quando todos os animais estiverem sentados/deitados, já mortos pelo caçador, pede-se que todos sentem ou levantem - assumindo a mesma posição, para que não haja diferenciação entre caçador (em pé) e animais (ao chão). Após, o detetive se vira para a turma (ou retira a venda dos olhos), pronunciando sua opinião a respeito de quem é o caçador. Dá-se o “caso” por encerrado se o detetive acertar quem representou o caçador. Caso erre, a turma anuncia que ele falhou em sua investigação, podendo-se iniciar o jogo novamente.

Na figura abaixo ${ }^{23}$ constam os registros do grupo criador do jogo "Música”. Os alunos desejaram anotar questões referentes às personagens e às regras do jogo.

\footnotetext{
${ }^{23}$ Transcrição da figura 5: “Grupo: Música. Personagens - Detetive: Adivinhar quem é o caçador. Caçador: Matar os bichos. Não em roda [referindo-se ao fato de que os jogadores não formariam uma roda]. Regras: 1 Detetive de olhos vendados. 2 - Caçador com barulho de flecha. 3 - O detetive tem que descobrir quem é o caçador só pelo som”.
} 


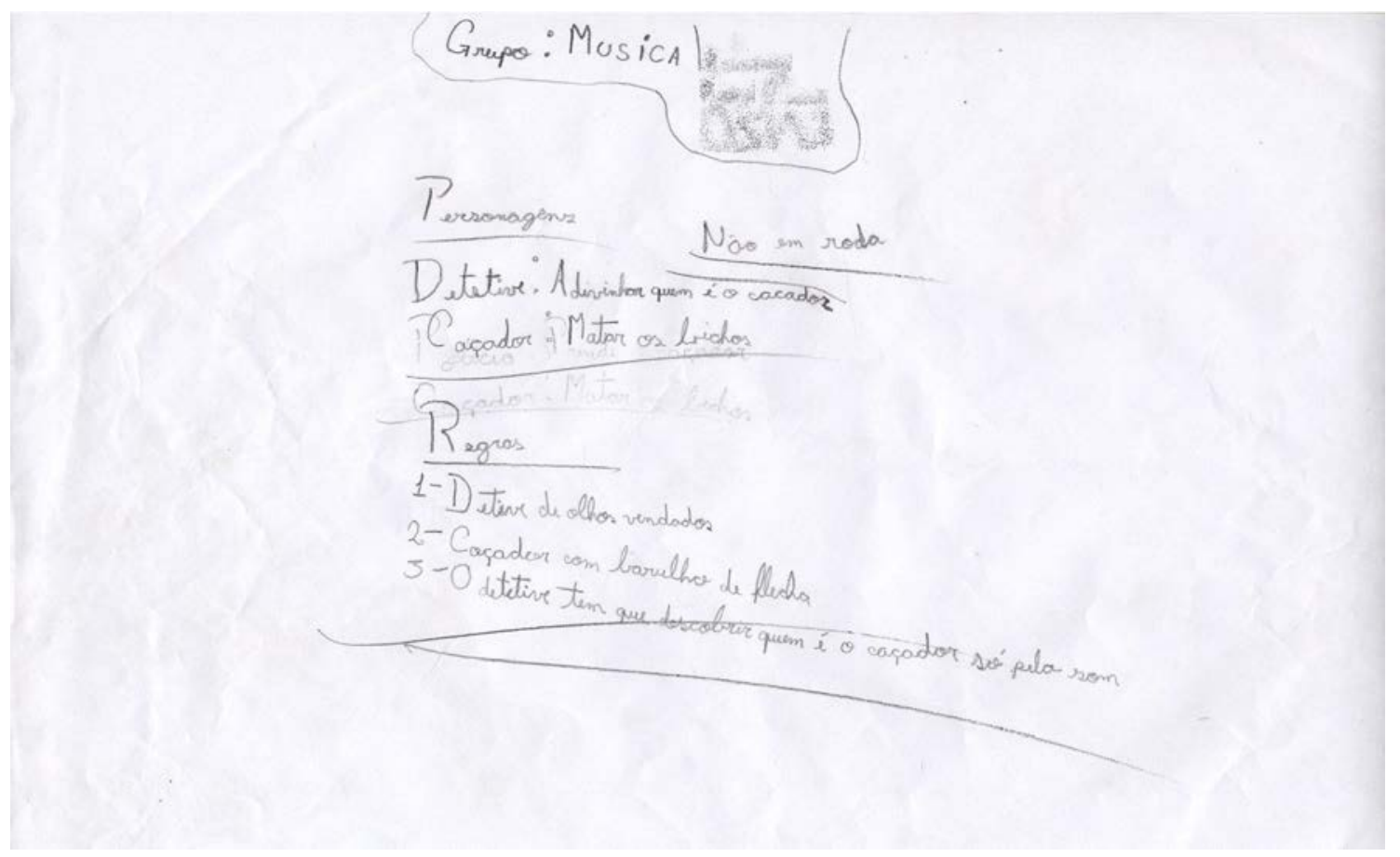

Figura 5 - Anotações referentes ao jogo Música.

\subsubsection{Criação 3 - Detetive ${ }^{24}$}

Este jogo deve ser realizado em roda, com um "detetive” fora desta posicionado de costas para todo o grupo (sem que possa visualizar os outros participantes). Dentre os jogadores da roda, um será escolhido para "comandar” o início do jogo ao emitir um som, assim como deverá ser responsável pela constante troca deste som por outros. Todos os outros jogadores em roda, por sua vez, deverão imitar/reproduzir o som inicial, como também os outros que decorrerão no jogo.

Após o primeiro som ser reproduzido pelo grupo, o detetive deverá se virar, posicionando-se de modo que visualize os jogadores em roda e passe a observar todos os participantes. Aquele responsável por iniciar a reprodução de um som - assobios, por exemplo - deverá alterar este som durante a execução do jogo - trocando por palmas, estalo

\footnotetext{
${ }^{24}$ Jogo criado pelos alunos Bernardo, Isabela, Marcos e Tiago.
} 
de dedos, entre outros. Entretanto, esta troca deve ser feita com atenção e discrição, de modo que escape do olhar do detetive quem a executou. O detetive, por sua vez, precisará estar atento para captar/perceber quem é o responsável por comandar as alternâncias sonoras. Os outros jogadores da roda, que reproduzem cada novo som emitido e alternado, deverão, portanto, evitar olhar para aquele que está comandando tais trocas, justamente para que o detetive não perceba quem é este através dos olhares direcionados do grupo.

O jogo encerra com o palpite do detetive, que descobrirá, ou não, qual jogador estava no comando da roda.

Os alunos criadores deste jogo realizaram registros acerca do mesmo. Entretanto, as ideias iniciais registradas não correspondem ao jogo em sua "formação final”. Isto ocorreu devido às modificações pensadas pelos alunos no percurso da criação. Logo, alguns elementos - tais como o uso do tambor - foram retirados enquanto outras ideias/elementos foram inseridos. Seguem na figura abaixo algumas anotações ${ }^{25}$ :

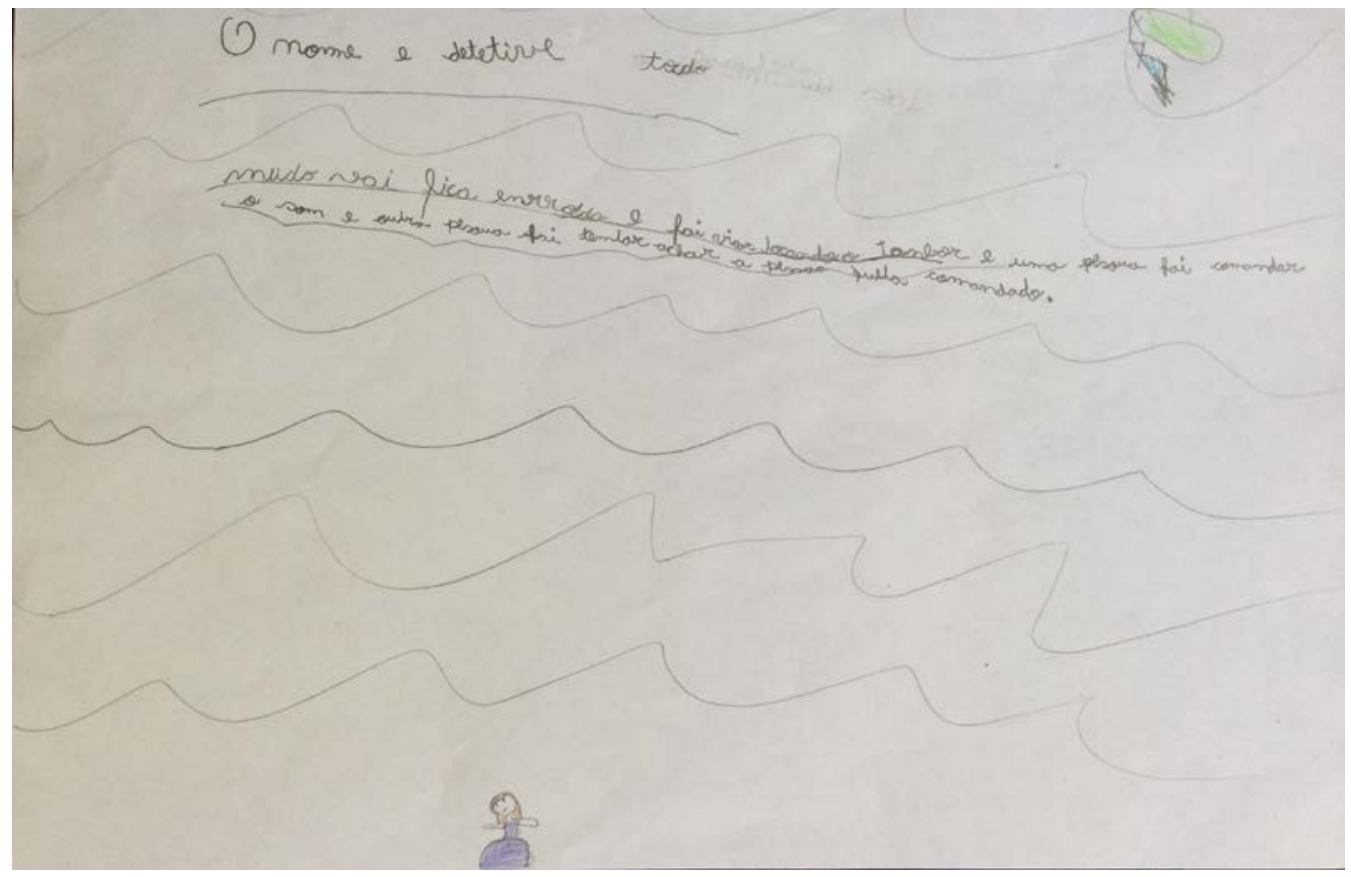

Figura 6 - Anotações referentes ao jogo Detetive.

${ }^{25}$ Transcrição da figura 6: "O nome é detetive. Todo mundo vai ficar em roda e vai ficar tocando o tambor e uma pessoa vai comandar o som e outra pessoa vai tentar achar a pessoa que está comandando o som”. 


\subsubsection{Criação 4 - Competição de instrumentos ${ }^{26}$}

Este jogo diferencia-se bastante dos outros criados na Oficina de Música, tendo em vista que ele não vem completamente "pronto". Ele desencadeia outros jogos: jogos de composição musical... Dependerá, portanto, das criações que a turma fará para que ele funcione como previsto.

A proposta consistia, inicialmente, na divisão da turma em grupos, cada qual responsável por criar uma composição musical utilizando os instrumentos disponíveis em sala. Debate-se acerca do tempo que os grupos terão para suas invenções e dá-se início ao jogo. Após o término do tempo combinado, as composições devem ser apresentadas à turma. Um “juiz”, personagem do jogo anteriormente escolhido pelos alunos, deverá atribuir notas para cada composição, escolhendo qual delas será a vencedora da “competição musical ${ }^{27}$ ”.

Algumas questões são importantes ressaltar: na Oficina de Música, decidiu-se que o juiz seria representado pela aluna Fernanda, pois ela havia faltado a aula no dia da realização deste jogo. Logo, por não fazer parte de nenhum grupo e, consequentemente, não ser criadora de nenhuma das composições que estavam “concorrendo” à vitória, poderia agir com maior imparcialidade do que outros alunos - jogadores que poderiam nomear suas próprias composições como ganhadoras. Assim, mostramos a ela os registros audiovisuais das composições executadas na aula anterior e ela fez sua escolha.

Outra questão importante a colocar diz respeito à atribuição de notas. A descrição do jogo exposta acima, converge com as regras pensadas por seus inventores. Entretanto, na Oficina de Música, os criadores do jogo foram questionados acerca das "notas" que seriam dadas aos grupos. Buscou-se respeitar o sentido do jogo para aqueles alunos, que consistia justamente na competição entre composições, mas sugeriu-se que não precisaria haver uma atribuição de notas. Bastaria, portanto, que o “juiz” comentasse a respeito das criações ouvidas, analisando-as e escolhendo aquela que, em sua opinião, venceria o jogo. Os alunos que criaram o jogo concordaram com esta ideia e as notas não foram atribuídas. Ao invés

\footnotetext{
${ }^{26}$ Jogo criado pelos alunos Bruno e João.

${ }^{27}$ O grupo registrou em seu protocolo o nome do jogo como “competição de instrumentos”. Porém, em diversas explicações à turma, referiam-se ao jogo como “competição musical”.
} 
delas, a aluna Fernanda, eleita “juíza”, fez comentários acerca do trabalho desenvolvido pelos grupos, analisando e escolhendo uma composição como ganhadora da competição.

Os registros de Bruno e João, referentes ao jogo criado pelo grupo, constam na figura abaixo $^{28}$.

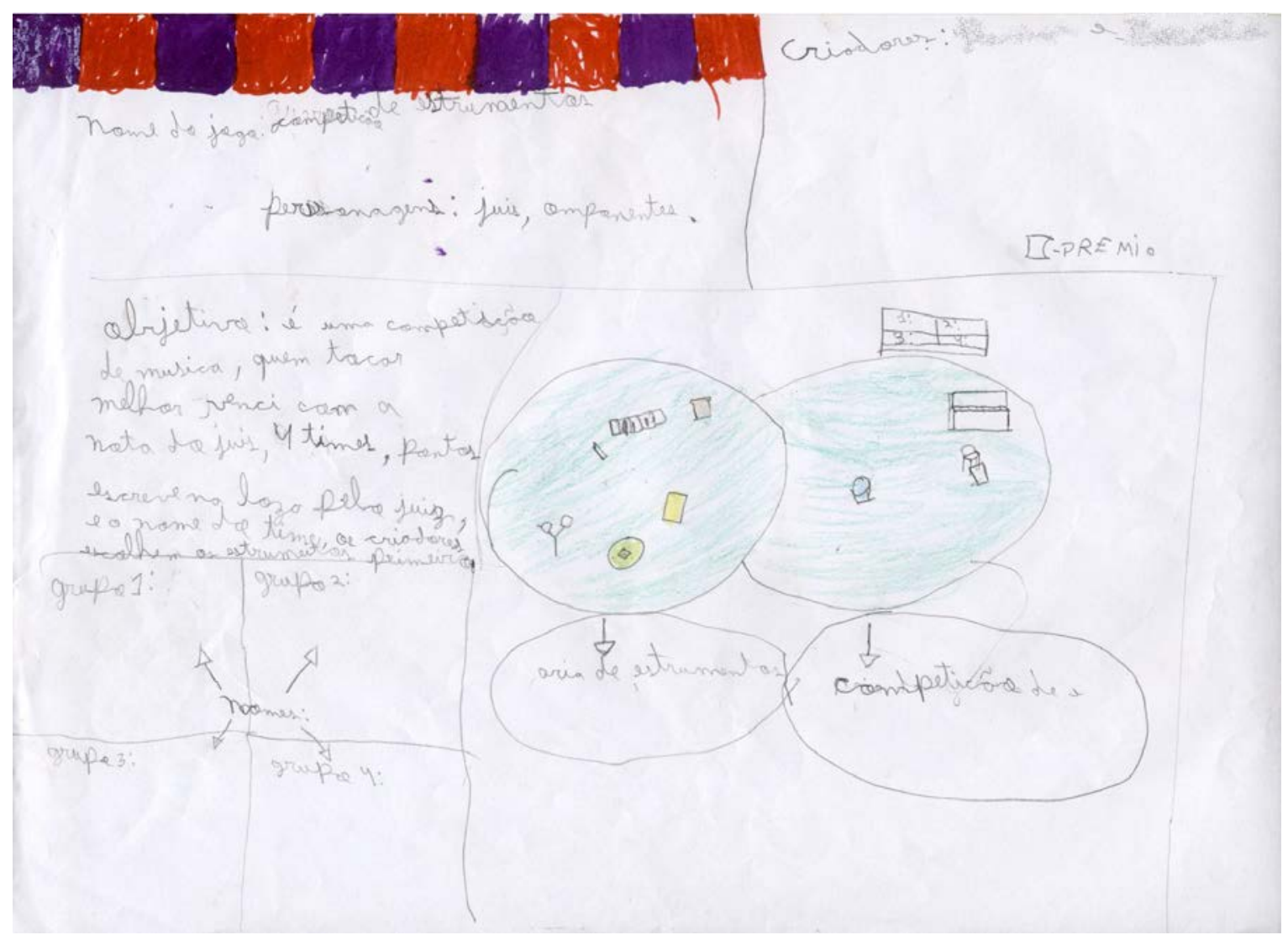

Figura 7 - Anotações referentes ao jogo Competição de instrumentos.

${ }^{28}$ Transcrição da figura 7: "Nome do jogo: competição de instrumentos. Personagens: juiz, oponentes. Objetivo: é uma competição de música, quem tocar melhor vence com a nota do juiz. 4 times. Pontos escreve na lousa pelo juiz, e o nome do time [os alunos referiam-se ao nome de cada grupo/equipe, assim como as pontos que elas receberiam e que deveriam ser escritos na lousa pelo juiz]. Os criadores escolhem os instrumentos primeiro”. 


\section{3 “É QUE VOCÊ SE DIVERTE MAIS BRINCANDO": O ENSINO E APRENDIZAGEM DA MÚSICA NO AMBIENTE DO JOGO CÊNICO-MUSICAL}

As informações obtidas durante a prática da pesquisa-ação serão analisadas neste capítulo, indicando as possíveis contribuições das experiências de improvisação em jogos cênico-musicais para a formação integral das crianças.

A partir dos meios de coleta de dados expostos no capítulo anterior ${ }^{29}$, pôde-se alcançar a perspectiva dos alunos participantes acerca dos jogos vivenciados em sala de aula. O comportamento das crianças durante a Oficina de Música, seus comentários, os apontamentos levantados por elas durante as entrevistas, assim como os registros realizados nos protocolos, permitiram que a questão de pesquisa pudesse ser tratada e respondida, tendo suas colocações como ponto de partida para as argumentações desenvolvidas nesta dissertação ${ }^{30}$.

Deste modo, procurou-se ouvir e dar voz às crianças, atentando para a maneira como essa experiência "afetou” as mesmas, além de considerar a importância de assegurar as opiniões das próprias crianças nas pesquisas que as envolvem, levantando reflexões também com base no que elas pensam a respeito de um trabalho, considerando-as agentes sociais que constroem modos particulares de significação de mundo (BURNARD, 2006; GRIFFIN, 2009; SARMENTO, 2003).

No decorrer da análise de dados, apontamentos gerais e específicos foram trabalhados, ou seja: tanto descrições relacionadas a todos os alunos envolvidos na pesquisa (tais como a reação da turma frente aos jogos e à oportunidade de criar/ improvisar), quanto relatos de casos específicos, relacionados a uma criança de forma mais particular.

Vale ressaltar que os subcapítulos, muitos nomeados com as falas das próprias crianças, abarcam “cenas”, falas e reações observadas na Oficina de Música. Eles podem ser lidos “fora de ordem”, tendo em vista que a cada novo tópico levanta-se uma nova cena,

\footnotetext{
${ }^{29}$ Tais informações podem ser visualizadas entre as páginas 74 e 81 da dissertação.

30 As falas das crianças foram transcritas da maneira como foram pronunciadas, sem correções ortográficas. Optou-se por não utilizar o "sic" para que a leitura dos relatos pudesse ser feita de maneira fluente, sem intervenções constantes que indicassem os erros.
} 
novos relatos, novas ideias. Todos, entretanto, partem de um objetivo (estando, de certa forma, entrelaçados): apontar as contribuições dos jogos de improvisação para a formação musical e humana da criança.

\subsection{JOGANDO E APRENDENDO}

Os jogos foram percebidos pelas crianças como ambiente em que se pôde aprender brincando. Notou-se que, durante a realização das atividades lúdicas, as crianças vivenciaram momentos de entrega, prazer e alegria, experimentando um espaço de liberdade que as mantinham longe de tensões. Tais afirmações podem ser apresentadas considerando-se tanto as observações da pesquisadora - atenta às risadas e à diversão que os alunos usufruíram frente ao ato de jogar - quanto os comentários e reflexões levantadas pelos próprios alunos. Santana (2004) também relata que nos momentos em que participou ou observou experiências lúdicas, pôde constatar este estado de alegria nos participantes. A autora afirma:

Em todas as atividades pude perceber que os participantes, quando se entregavam a experiências lúdicas, viviam momentos de grande significado pessoal, e saíam leves, renovados, muitas vezes relatando ter tomado contato com um estado de alegria que já nem lembravam mais que existia (SANTANA, 2004, p. 27).

Durante as aulas na Oficina de Música ou, ainda, nas entrevistas realizadas, as crianças comentaram a possibilidade de se divertirem, brincarem e, simultaneamente, aprenderem. Patrícia, por exemplo, afirmou durante uma das entrevistas que achou "legal” o aprendizado da música através do jogo por um motivo: "porque você se diverte mais brincando pra aprender música” (Patrícia - registro audiovisual).

Esta sensação de diversão e prazer foi apontada por outros participantes, tais como Gabriela. Esta aluna comentou, também durante uma entrevista, que fazia aulas de música em outro local, porém, lá não aprendia música por meio de jogos. Quando questionada acerca do que pensava sobre aprender através de jogos, ela respondeu: "eu gostei porque eu gosto de jogar e brincar aprendendo [...] é legal fazer música brincando” (Gabriela - registro audiovisual). 


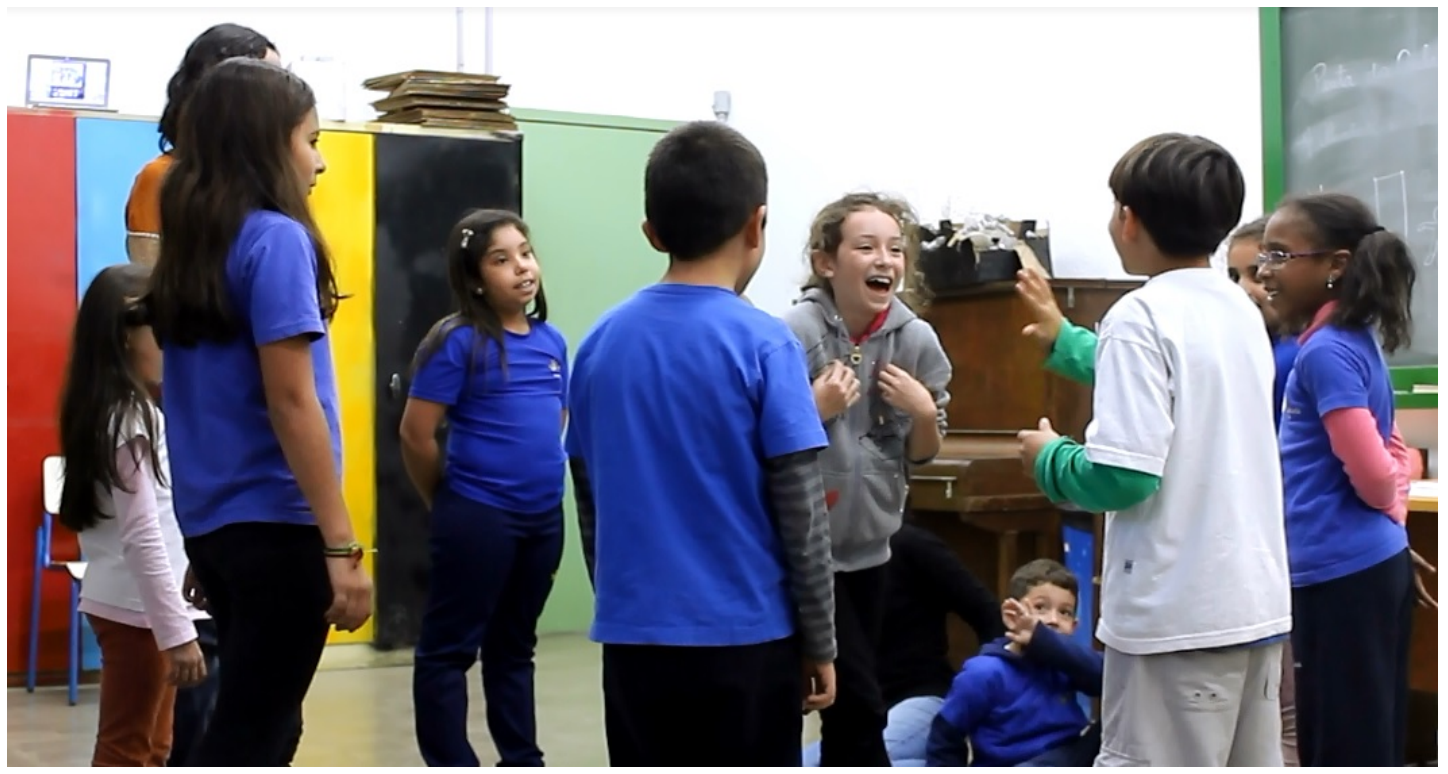

Figura 8 - Participantes da Oficina de Música durante o jogo Floresta e seus bichos.

A frivolidade relacionada ao jogo se mostrou favorável ao aprendizado também no contexto da Oficina de Música. Lombardi (2005), trazendo a abordagem de Brougère (1998) a respeito desta característica, comenta a sensação de liberdade vivenciada pelo jogador, o que permite atitudes ousadas por parte do mesmo e, consequentemente, aprendizados.

Vemos autores como Brougère (1998) afirmar que até mesmo a frivolidade ligada ao jogo se mostra favorável ao aprendizado, já que o jogador sente-se livre para fazer tentativas que não ousaria fazer na vida comum, justamente devido a esta aparência de falta de consequência ligada à atividade lúdica. Aprende-se jogando (LOMBARDI, 2005, p. 96).

O aprender relacionado ao brincar foi valorizado pelas crianças. Larissa, por exemplo, falou: “achei legal porque a gente pôde se divertir muito” (Larissa - registro audiovisual). Já a aluna Fernanda afirmou que, por ser uma Oficina, o "legal” é que haja diversão, comparando aulas de música em que o professor escreve na lousa e os estudantes leem explicações com uma Oficina onde se brinca com a música. Para ela, aprende-se mais por meio deste brincar.

Eu achei importante porque é uma Oficina, e nas oficinas é legal se divertir, brincar. Mas ficar lá escrevendo na lousa, lendo explicação, é chato. Porque eu já tenho aula de música, e fica escrevendo na lousa. É meio chato. Mas agora se você faz uma oficina e fica brincando com aquela coisa de música é mais legal. A gente aprende mais, a gente observa. É bem mais legal (Fernanda - registro audiovisual). 
Em uma das entrevistas em grupo, quando questionados acerca dos jogos vivenciados na oficina, o aluno Bernardo ressaltou que é preciso “curtir” quando se é criança. Chegou-se neste comentário a partir das ideias anteriormente expressas, que indicavam os jogos como “legais” e atentavam para o fato de que todo mundo gosta de brincadeiras. O seguinte diálogo (entre a pesquisadora, o aluno Bernardo e a aluna Patrícia) emergiu, suscitando risadas durante a entrevista.

Pesquisadora: o Bernardo... [direcionando a pergunta para este aluno] o quê que acha dos jogos que a gente está fazendo?

Bernardo: legal.

Pesquisadora: legal? Porque que tu acha eles legais?

Bernardo: legal porque tem muita música, tem muitas brincadeiras.

Patrícia: todo mundo gosta de brincadeiras né?

Bernardo: e quem não gosta? Tem que curtir quando é criança. Vida boa... [risos]

Estes são alguns dentre os vários apontamentos das crianças acerca do jogo como ambiente para se aprender brincando, para curtir e se divertir, associando-o ao prazer. Autores como Huizinga (2012), Januzelli (2003) e Pereira (2012) também abarcam tais ideias, afirmando que o jogo propicia diversão, descontração, confiança e liberdade para a criação, além de despertar o interesse e cativar o jogador.

O aluno Bernardo, por meio do diálogo exposto acima, indicou também que, enquanto se é criança, é preciso curtir. Tal afirmação deveria ser considerada pelas escolas e educadores atualmente, de modo que buscassem criar e defender os espaços para o brincar também nas salas de aula, tendo em vista que o desenvolvimento das crianças ocorre por meio do lúdico (LOMBARDI, 2005). Segundo Lombardi (2005, p. 93), “a importância de o professor conhecer sobre jogos, brincadeiras e brinquedos está em ser capaz de respeitar o desenvolvimento natural das crianças, o qual ocorre por meio destas atividades”. Assim, o ato de se divertir, a "curtição” exposta por Bernardo, não deveria ser delegado apenas à hora do “recreio", mas estar presente na sala de aula. Novamente, portanto, pode-se levantar a ideia defendida por Lima (2008): o jogo como recurso pedagógico, presente nos processos de ensino e aprendizagem. 


\subsection{LIBERDADE E DESINIBIÇÃO: EXPERIÊNCIAS EM JOGO}

A descontração e a eliminação de bloqueios experimentados pelas crianças nos jogos de improvisação também geraram momentos de desinibição e infração às regras. Huizinga (2012), tratando desta última questão, estabelece relações entre o jogo, suas regras e aqueles que desrespeitam tais normas. O autor apresenta a figura do "desmancha-prazeres", que consiste no jogador que infringe o regulamento do jogo.

O jogador que desrespeita ou ignora as regras é um 'desmancha-prazeres'. Este, porém, difere do jogador desonesto, do batoteiro, já que o último finge jogar seriamente o jogo e aparenta reconhecer o círculo mágico. É curioso notar como os jogadores são muito mais indulgentes para com o batoteiro do que com o desmancha-prazeres; o que se deve ao fato de este último abalar o próprio mundo do jogo (HUIZINGA, 2012, p. 14).

Na Oficina de Música, por exemplo, o aluno Tiago aproveitou-se de um momento de muita correria e divertimento para "roubar" durante o jogo. As "infrações” cometidas por Tiago durante o "Pega-congela sonoro" provocaram reações em Pedro, aluno que assumia o papel de pegador. Ainda que Pedro insistisse em “congelar” Tiago, este último não atendia às regras, continuando a correr pela sala. Pedro, entretanto, por ser um aluno bastante tímido, não se manifestou inicialmente ${ }^{31}$. Todavia, ao longo do jogo, a quebra das regras por Tiago gerou irritação em Pedro que, de repente, passou a contestar, defendendo a atuação de seu personagem ao explicar que já havia congelado todos os perseguidos - apesar de Tiago continuar correndo. A reação de Pedro chamou a atenção de algumas pessoas que estavam jogando ou observando a aula. Ele parecia ter se "libertado" em jogo, expressando-se de maneira não comum. Deste modo, ressalta-se a importância do jogo como espaço que fomenta a espontaneidade e a liberdade (JANUZELLI, 2003; JAPIASSU, 2003; MARTINS, 2008; PEREIRA, 2012; SPOLIN, 2012a, 2012b).

\footnotetext{
${ }^{31}$ Este aluno não costumava falar em sala. Raramente expunha suas opiniões. Quando a pesquisadora dirigia alguma pergunta a ele, ou quando se iniciava um debate a respeito dos protocolos, Pedro movimentava a cabeça de um lado para o outro, em sinal de que não queria falar. Até mesmo durante as entrevistas, Pedro procurava não responder ou, ainda, dar respostas curtas. Em alguns momentos, a captação de sua voz, inclusive, tornou-se possível apenas pela aproximação das câmeras para mais perto do aluno.
} 
Ainda que em contextos diferentes, a pesquisa que desenvolvi no ano de 2012, durante o trabalho de conclusão de curso, também apontou a reação de desinibição dos alunos frente ao ato de jogar. Tanto na pesquisa-ação desenvolvida com universitários estudantes de canto, quanto na Oficina de Música realizada com crianças no ano corrente, percebeu-se que as ações e reações dos alunos tornaram-se mais espontâneas durante o jogo. Os estudantes de canto, por exemplo, relataram a existência "de uma desinibição, dizendo que cantar em frente ao grupo tornou-se algo mais tranquilo quando realizado dentro do contexto lúdico” (ZANETTA; JACOBS, 2013, p. 2362). Dentre diversos outros comentários, apontaram:

\footnotetext{
'A aula teve bastante dinâmica e foi muito divertida. Serviu de certa maneira para nos desinibir, porque eu tenho muita vergonha e consegui me soltar e fazer as atividades propostas.' (Lara - protocolo). Outra estudante também enfatizou a questão de conseguirem 'se soltar', dizendo que 'todos [os jogos] acabam sendo muito bons porque acima de tudo é um jogo onde todos acabam se soltando mais, o que torna mais produtivo' (Beatriz - protocolo). (ZANETTA; JACOBS, 2013, p. 2362-2363).
}

Acredita-se que, em jogo, desfruta-se de um momento de liberdade e liberação de tensões, em um espaço onde as preocupações com erros ou acertos são minimizadas. Pedro, enquanto esteve jogando, vivenciou estas sensações. Porém, após sair do "mundo do jogo”, voltou a se comportar como anteriormente: de forma tímida, sem expor suas opiniões, evitando falar com os colegas, dentre outras características observadas. O ambiente do jogo permitiu, portanto, a experiência da espontaneidade, a "liberação" da vontade de reivindicar e contrariar os atos de Tiago.

No trabalho realizado em 2012, narro um momento semelhante ao vivenciado por Pedro. Trata-se do aluno Carlos que, apesar da vergonha/timidez exposta durante as aulas de canto, pôde experimentar situações de maior espontaneidade durante o jogo. No contexto daquela pesquisa-ação, ao término do "Jogo das placas", muitos alunos começaram a comentar acerca do jogo vivenciado. Dentre eles estava Carlos, que buscou expor suas opiniões, mas foi interrompido pelas falas de outros alunos e, após algum tempo, não desejou mais falar. Percebeu-se, naquele contexto de pesquisa-ação, que o jogo permitiu a eliminação de bloqueios, “impulsionando" Carlos a desejar relatar suas impressões do momento em cena. Entretanto, após algum tempo fora de jogo, este “impulso” e desejo de compartilhar não manteve as mesmas proporções. Este, dentre outros exemplos e aspectos observados em sala, 
permitiram compreender o jogo como ambiente propício a reações mais espontâneas também no contexto de aulas de canto com alunos do curso de graduação em música.

Assim, acredita-se que a aprendizagem em ambientes lúdicos proporciona tanto o prazer do "aprender brincando", assim como o desfrute da liberdade e espontaneidade refletidas nas ações e reações dos alunos. Logo, a frivolidade associada ao jogo propicia relaxamento, desinibição, diversão e, consequentemente, um melhor aproveitamento e aprendizados (ZANETTA, 2012, ZANETTA; JACOBS 2013).

\section{3 “EU PENSEI QUE IA ESCREVER NA LOUSA” E “ACHEI QUE IA SER CHATA”: AS VIVÊNCIAS COM OS JOGOS CONTRAPONDO CONCEPÇÕES DE AULAS DE MÚSICA}

Em outros momentos da pesquisa atual, os alunos da Oficina de Música compararam o “aprender brincando” com suas concepções de aulas de música - que, em alguns casos, refletiam experiências pelas quais as crianças haviam passado em outras aulas/escolas. No primeiro tópico deste capítulo, por exemplo, foi exposta a fala de Fernanda, aluna que indicou, além do fato de “aprender mais” quando se brinca, a "chatice” de uma aula em que lê explicações registradas na lousa. Assim como Fernanda, Marcos e Patrícia levantaram suas ideias de aula de música.

Durante uma entrevista, Marcos relatou que não escolheu participar da Oficina de Música, mas que sua professora havia preenchido o formulário para ele, tendo em vista que Marcos não estava na escola no dia em que a escolha das Oficinas foi realizada pelas crianças. Ele contou que pensava que a Oficina seria “chata”, pois achava que ficaria apenas "tocando as coisas", ao invés de experimentar uma vivência com jogos, com "um monte de coisas legais”.

Acho legal música jogando [...] porque a gente ouve o som de todo mundo tudo junto! [...] Nem tinha sido eu que tinha escolhido porque eu tinha faltado no dia que era pra escolher, aí foi a professora que escolheu pra mim essa Oficina. Eu não sabia que ia ter essa [Oficina]. Achei que ia ser chata, que ia ser chata, mas não é não! Eu não sabia que ia ter um monte é ... fazer pega-pega com sons, um monte de coisas legais! Eu não sabia. Eu sabia [achava] que ia ser só tocando as coisas. Mas não... mas é de outro jeito. É legal (Marcos - registro audiovisual). 
Patrícia também compartilhou que imaginava encontrar, na Oficina de Música, uma professora escrevendo na lousa, alunos tocando o que havia sido escrito e, caso houvesse “erro”, alunos que precisariam reiniciar a música. Durante sua fala, ela expôs tanto ideias/concepções de uma aula de música, assim como o aspecto da diversão no aprendizado:

Eu pensei que ia escrever na lousa, que a gente tinha que tocar alguma coisa e você escrevendo... se tava errado a gente teria que voltar desde o começo! Aí eu achei legal, porque você se diverte mais brincando pra aprender música (Patrícia - registro audiovisual).

Tanto Fernanda quanto Patrícia, durante as entrevistas, expuseram outras opiniões e levantaram reflexões. Discutindo-se o aprendizado através dos jogos, assim como se deveriam ter aprendido outros conteúdos na Oficina, tais como as notas musicais (assunto levantado pelos próprios alunos durante esta entrevista em grupo, ao perceberem que em nenhuma das aulas as notas musicais foram “tradicionalmente ensinadas”), as alunas argumentaram:

Patrícia: a gente só tem oito dias [número de aulas da Oficina de Música]. Tipo: em oito dias a gente conseguiria ficar firme nas notas musicais? Eu acho meio chato isso. Prefiro brincando que a gente aprende mais.

Fernanda: é horrível essas notas musicais. Eu que tenho que decorar nota musical por nota musical e tenho que depois tocar na flauta... é horrível. Muito ruim [contando a experiência de outra aula de música da qual faz parte].

O relato de Fernanda reflete a persistência de um modelo de aula de música em que os atos de decorar e reproduzir são valorizados. Uma educação musical em modo menor ${ }^{32}$ (BRITO, 2007), que reconhece o modo menor musical da criança, atentando para o jogo do criar, do pensar e voltada às singularidades, parece ainda distante das salas de aula - ou, pelo menos, das concepções de aulas de música apresentadas por alguns alunos participantes desta pesquisa.

Neste sentido, ressalta-se a importância de tratar a música das/para as crianças não como um trabalho movido pelo preparar para operar (BRITO, 2007). Como afirma Brito

${ }^{32} \mathrm{O}$ conceito de menor, na perspectiva deleuziana, assim como de educação menor, na abordagem de Silvio Gallo, podem ser visualizados nas páginas 21 e 22 deste trabalho. Já o conceito de educação musical em modo menor, advindo de deslocamentos feitos por Brito (2007), consta nas páginas 22 e 23 da dissertação. 
(2007, p. 2), é preciso compreender a "música da infância não como repetição igual das notas da escala ou treinos incessantes para identificar isto ou aquilo, mas sim, como blocos de sensações que permitem ir e vir, construir e desconstruir, brincar com o tempo e o espaço, pensar, conversar e amar”.

\subsection{JOGO: UM TEMPO DENTRO DE OUTRO...}

A inserção do jogo nos processos de ensino e aprendizagem, à medida que gerou divertimento e o desejo de aprender mais pelo brincar, também provocou diferentes impressões de tempo. Os encontros da Oficina foram realizados semanalmente, às terçasfeiras. Logo após o término do primeiro encontro, Tiago demonstrou tristeza com o encerramento da aula e perguntou à pesquisadora: “A próxima aula de música é amanhã?” (Tiago - registro audiovisual). Este aluno esteve eufórico com os jogos que vivenciou em sala naquele primeiro dia, dentre eles o "Jogo dos nomes: relógio maluco" e o "Pega-congela sonoro”. Durante a aula, manifestou sua satisfação abraçando a pesquisadora diversas vezes. Percebeu-se, também por meio dos registros em vídeos, sua alegria e risadas durante a experiência de jogar com os sons. Quando a pesquisadora respondeu a questão, afirmando que retornaria em sete dias, ele lamentou e exclamou: “Ah! Vai demorar muito, né?” (Tiago registro audiovisual).

Uma das características do jogo citada ao longo desta pesquisa é o fato deste possuir um tempo próprio. Este foi mais um aspecto constatado durante a prática da Oficina de Música: jogando, as crianças desprendiam-se de uma concepção de tempo “real” e se “perdiam” no tempo do jogo. Ao término de algumas aulas, elas ainda desejavam experimentar outros jogos. Quando a pesquisadora, entretanto, ressaltava que já não havia mais tempo, elas reclamavam e insistiam que ainda deveria haver tempo, perguntando quantos minutos ainda restavam. A sensação de que havia passado "rápido demais” e de que outros jogos “caberiam” nos encontros foi vivenciada tanto pelos alunos como pela pesquisadora em questão. Acredita-se que, como afirma Agamben (2005, p. 80-85), “a invasão da vida pelo jogo tem como imediata conseqüência uma mudança e uma aceleração do tempo. [...] Brincando, o homem desprende-se do tempo sagrado e o ‘esquece’ no tempo humano”. 
Brito (2007), embora analisando um trabalho desenvolvido com outro grupo de crianças, em outro ambiente de pesquisa, também enfatizou a existência deste "tempo" que passa depressa, deste local onde não há pressa. Segundo Brito (2007, p. 270), "uma educação musical em modo menor opera com outro conceito de tempo: tempo do acontecimento, do jogo, da surpresa. Tempo que cria devires, que dispara possibilidades, que permite experimentar, fazer, acertar ou errar. Que não tem pressa!” A autora faz menções a um tempo liberto do calendário letivo, dos sistemas de avaliação quantitativos, assim como da obrigação de produzir quantidades. Logo, experimenta-se um "outro tempo", uma "outra dimensão", onde há espaço para o fazer, para a reflexão, para as sensações, para as vivências, para o brincar, para o conviver, para o significar e para a emergência de singularidades.

\footnotetext{
Tempo vivencial que convida ao fazer/refletir, estimulando o conviver, estimulando a coragem de fazer, guiando-se pelo jogo. Tempo que passa depressa quando estamos juntos fazendo música, mas que nem por isso acelera processos ou impede o emergir de singularidades. Tempo liso das sensações, das vivências, do brincar. Do significar. Não à toa, disse o Gabriel, de cinco anos, referindo-se ao tempo-relógio da aula de música, ao chronos: "A gente devia ter uma varinha mágica pra fazer parar o tempo quando a gente está aqui.”. Tempo mágico que nos permite viver muitos tempos junto com as crianças (BRITO, 2007, p. 270).
}

Huizinga (2012) também apresenta o jogo como um mundo temporário dentro do mundo habitual. Coelho (2011) ressalta o ambiente lúdico como um "outro mundo", indicando que a imersão do jogador no universo lúdico gera a sensação de afastamento da realidade. Csikszentmihalyi (apud PAREDES ORTIZ, 2005) relata que o jogo proporciona experimentar uma sensação de fluir, sensação esta que nos transporta a um local onde abstraímos a realidade e nos expressamos como somos.

O jogo, portanto, consiste em um tempo-espaço próprio e, de acordo com Brito (2007), é como jogo que as crianças fazem música, experimentando este "lugar do fruir, do brincar, do viver pura e simplesmente movido pelo desejo, pela vontade, pelo prazer" (BRITO, 2007, p. 271). Segundo a autora, isto implica em outras maneiras de viver esta experiência do tempo.

\subsection{CONSCIENTIZANDO ASPECTOS MUSICAIS}


Durante os jogos de improvisação, as crianças lidavam com diferentes conteúdos musicais, trabalhando com a ideia de pulso, de tempo métrico e não métrico, com pesquisa de timbres, explorando dinâmicas, alturas, improvisando livremente - com o uso de instrumentos convencionais e não convencionais - dentre muitos outros tópicos. Os alunos debatiam a respeito da exploração e criação sonora, entrando em contato com conteúdos musicais que eram destacados na proposta ou, ainda, com aqueles que emergiam no decorrer dos jogos.

Pesquisando maneiras de tocar instrumentos desconhecidos, definindo como usariam tais instrumentos nas improvisações e questionando se o instrumento escolhido "combinaria" com a proposta, as crianças ampliavam e conscientizavam conhecimentos musicais. Houve momentos em que alguns alunos, após conversas com seus grupos acerca do trabalho que seria realizado em sala, deixaram de lado um instrumento escolhido anteriormente, pois acreditavam que outro se tornaria mais adequado. Em outras situações, eles ouviam as ideias de música dos colegas (até mesmo daqueles que não faziam parte de seus grupos), pensavam a respeito delas e, por fim, redefiniam suas ideias a partir da ajuda de outras crianças. As práticas musicais, desta forma, estiveram atreladas às reflexões acerca das mesmas, configurando a proposição de uma Oficina de Música (como mencionado no capítulo 2 deste trabalho).

Não apenas no decorrer dos jogos, mas também nos protocolos e nas entrevistas, as crianças indicavam os aspectos musicais vivenciados e as novas concepções acerca destes. Em uma das entrevistas, por exemplo, um aluno resolveu explicar e mostrar à pesquisadora o instrumento que havia inventado. Dando prosseguimento à sua fala, ele passou a explorar sons de seu próprio corpo. Tratava-se, portanto, da compreensão do corpo como um instrumento musical - compreensão que pôde ser gerada durante as aulas, principalmente na vivência de jogos como "Floresta e seus bichos" e "Detetive", nos quais os alunos trabalhavam com a criação de sons corporais ${ }^{33}$.

Foram muitas as transformações nas concepções musicais das crianças, dentre as quais cito: (1) a ideia de que instrumentos convencionais não constituem a única fonte sonora para fazer música, mas também outros recursos e fontes - dentre estes o próprio corpo; (2) a

\footnotetext{
${ }^{33}$ Este relato será especificado adiante.
} 
"descoberta de sons", enfatizada por diferentes alunos - descobertas resultantes de explorações sonoras em sala; (3) a compreensão acerca de "como" se faz uma música (questão apontada durante as entrevistas), envolvendo pensar na fonte sonora a ser utilizada, na maneira como ela será tocada, na exploração de diferentes alturas, intensidades/dinâmicas, além de questões formais, ideias de arranjo e contrastes sonoros que poderiam ser propostos; (4) e até mesmo concepções acerca de uma aula de música, compreendendo-a como momento de exploração e criação (e não apenas de reprodução).

Vale ressaltar que estes conteúdos musicais, abordados em jogos coletivos, foram, posteriormente, tratados pelas crianças enquanto elas realizavam trabalhos em grupos. Quando criaram, por exemplo, músicas para o jogo “Competição de instrumentos”, os alunos pesquisaram os timbres dos instrumentos, modificaram a escolha de instrumentos de seu grupo, debateram o arranjo da peça, fizeram anotações referentes à forma da obra e às intensidades que seriam exploradas no decorrer da interpretação, dentre outras análises. Na figura abaixo, que apresenta o protocolo de Gabriela e Larissa, algumas destas questões podem ser observadas. Ao compor uma música para o jogo citado acima, estas alunas optaram por tocar uma castanhola e uma flauta, fazendo anotações acerca dos instrumentos, da forma da peça (indicando como os instrumentos seriam intercalados) e das dinâmicas que seriam exploradas em determinados momentos da obra.

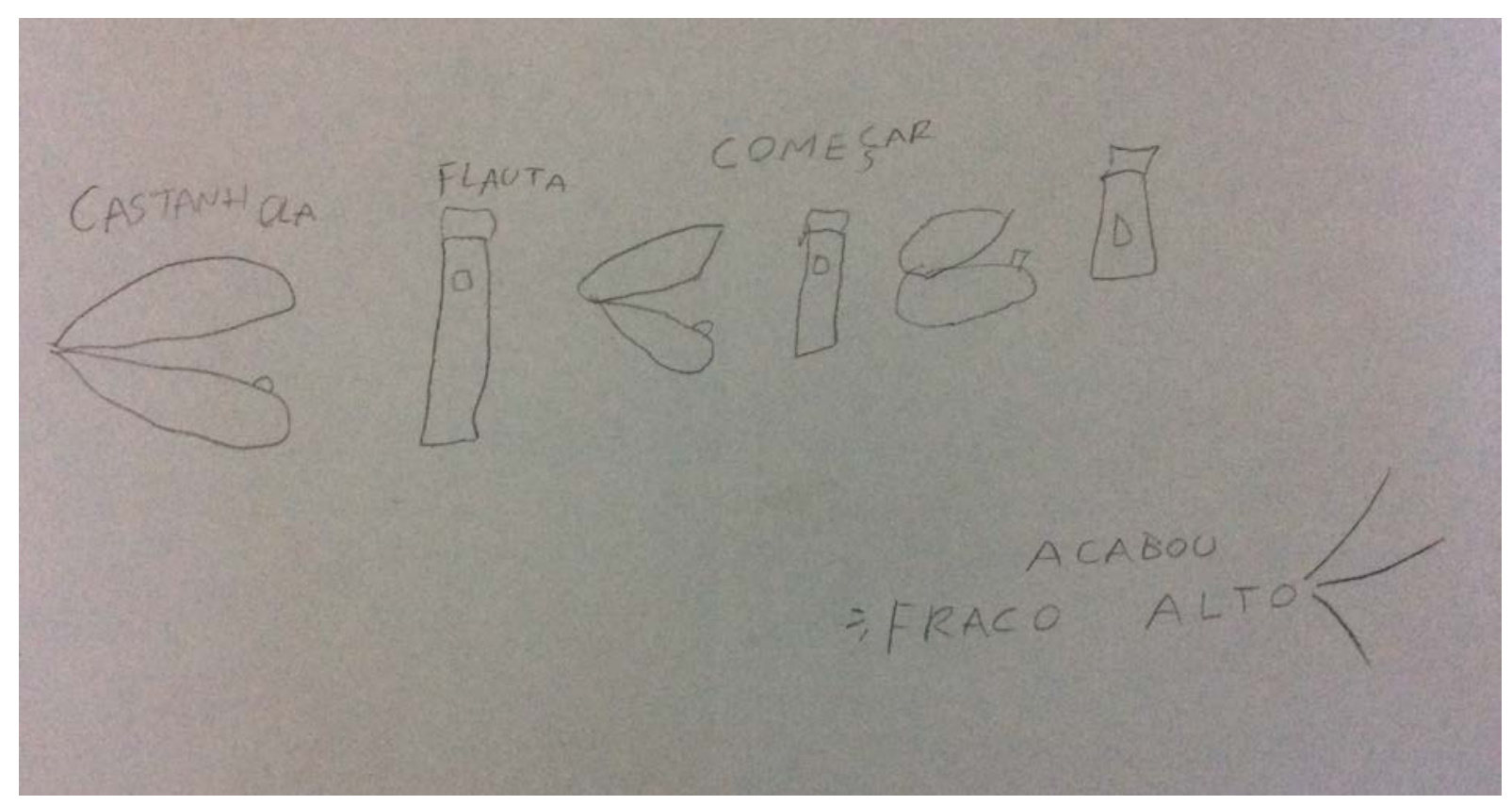

Figura 9 - Protocolo de Gabriela e Larissa. 
Os relatos das crianças permitem uma compreensão acerca dos aprendizados musicais conscientizados no decorrer da proposta. Acredito que as falas dos alunos - valorizadas nesta pesquisa - atestam a importância da proposta da Oficina de Música para o desenvolvimento de suas capacidades musicais. Deste modo, elas serão expostas a seguir, revelando descobertas sonoras e ideias de música ampliadas no processo.

\subsection{O “SOM DE LEÃO”: O APRENDIZADO DA MÚSICA NOS JOGOS DE IMPROVISAÇÃO}

Compreendendo a importância dos espaços para o jogo e para a criação, de maneira a respeitar também o desenvolvimento da criança e seu modo menor musical, buscou-se proporcionar momentos de autonomia, descobertas e invenções nas aulas da Oficina de Música por meio dos jogos de improvisação. Após vivências neste processo simultâneo de brincar/aprender, os alunos destacaram não apenas os aspectos de diversão e prazer do jogo, as sensações de um “tempo" que passa depressa, mas também o que haviam aprendido neste contexto lúdico.

Marcos, quando questionado acerca do que pensava que aprendíamos enquanto jogávamos, respondeu prontamente: “sons diferentes!” (Marcos - registro audiovisual). Durante a entrevista, este aluno ressaltou que nunca soube fazer o "som de leão”. Entretanto, na Oficina, pôde aprender a imitar tal animal com o seu colega Tiago. As colocações de Marcos demonstraram não apenas o interesse e satisfação pela descoberta de novos sons, mas também a existência de aprendizado por meio da ajuda de outro aluno participante da Oficina, revelando as relações interpessoais estabelecidas durante o trabalho - aspecto que será discutido mais profundamente em tópico à frente.

O aluno também comentou (e enfatizou durante algum tempo da entrevista) o quanto havia gostado de ouvir "o som de todos” ao invés do "som de cada um”, narrando o gosto pelo aglomerado de sons presentes na realização coletiva dos jogos de improvisação. Inclusive, este foi um dos fatores apresentados por Marcos para explicar o motivo pelo qual gostou dos jogos trabalhados em sala. 
Notou-se que os jogos desenvolvidos no decorrer da Oficina de Música permitiram espaços de exploração sonora, propiciando pesquisas e descobertas de novos sons - tais como o “som do leão” - além da invenção/criação durante as improvisações. Pereira (2012) também destaca, no contexto de sua pesquisa - que envolveu jogos para o trabalho vocal com estudantes de teatro - que assim como a técnica vocal, o jogo consistiu em um meio para descobrir possibilidades de exploração sonora através da voz. A partir das observações erguidas pelos estudantes e dos registros realizados durante o trabalho, Pereira (2012, p. 124) constatou que "tanto a técnica quanto o jogo são meios para descobrir novas possibilidades para a exploração vocal”. O autor cita, como exemplo, a paisagem sonora obtida no jogo “Mamenê”, ressaltando que houve a criação de uma atmosfera peculiar, um estímulo à exploração de timbres e a instauração de um ambiente propício para experimentação vocal sem medo/constrangimento diante dos outros (PEREIRA, 2012, p. 173). Nesta perspectiva, pode-se afirmar que "o prazer que envolve o jogo, na ludicidade do pesquisar, do conhecer a si, do expressar, do escutar, do compartilhar, do brincar, permite que o processo criativo flua em potencial” (MARTINS, 2008, p. 33).

A exploração e a invenção são aspectos que devem ser valorizados e abarcados nas proposições pedagógico-musicais. Koellreutter defendeu a importância dos processos de criação e exploração sonora no ensino artístico, trabalhando-os também por meio de jogos. Para ele, a pesquisa de sons era necessária, visto que o educador se preocupava com o desenvolvimento da sensibilidade musical (BRITO, 2011).

Outro autor que enfatiza tais argumentos é o pesquisador e educador francês François Delalande (1941-). Segundo ele, os educadores devem estimular as crianças a fazer o que elas, espontaneamente, já fazem. Assim, trabalha-se na perspectiva de abranger e ampliar os interesses delas, por exemplo, pela pesquisa de objetos que produzem sons, pelo agir sobre esses sons, e com a prolongação da exploração sonora (bastando não impedi-las neste processo). Um dos objetivos ressaltados pelo educador é o desenvolvimento de atitudes musicais, centrando o trabalho pedagógico-musical na criação e no jogo, ao invés da assimilação de repertório e técnicas.

Delalande explica que há muitos anos a música se liberou não somente do sistema tonal, mas das notas e do papel pautado. Em uma espécie de retorno às fontes sonoras, os músicos contemporâneos negligenciaram as heranças das convenções da música escrita para reencontrar o poder primitivo dos sons ou o prazer do jogo. A música volta à infância. Por isso é possível conceber a música como uma disciplina 
de despertar, na qual o objetivo não é tanto de aprender a música, mas de desenvolver atitudes musicais, e isto, centrando-se as atividades sobre a criação, a invenção e sobre o jogo, e não sobre a assimilação de um repertório e de técnicas (ZAGONEL, 1999, s/p).

No processo de explorar sonoridades durante a Oficina de Música, outras descobertas foram feitas pelas crianças. Tiago (aluno do $1^{\circ}$ ano), por exemplo, compartilhou que não possuía instrumentos em casa, mas que havia inventado um instrumento. Durante uma entrevista, ele contou a respeito de seu novo instrumento, mostrando-o para a pesquisadora. Tratava-se da descoberta e compreensão do corpo como um instrumento musical - descoberta esta que se tornou possível por meio do pensar, como o próprio aluno enfatizou, ao dizer que aprendeu "com a cabeça”.

Pesquisadora: o que você achou de aprender música com jogo?

Tiago: eu aprendi sobre todos os instrumentos. Eu não tenho um instrumento em casa. E eu inventei um instrumento assim ó: [o aluno começa a bater palmas e prossegue fazendo vários sons com o corpo] Também aprendi assim: [o aluno começa a assobiar]

Pesquisadora: onde você aprendeu isso?

Tiago: eu aprendi com a minha cabeça.

Outras falas remetem à postura das crianças frente ao exercício do pensar. Durante a escolha de sons que precisariam criar, Bruno questionou se poderia escolher o "silêncio" como seu som para aquele jogo. Ele perguntou: “o som pode ser o silêncio?” (Bruno registro audiovisual). Repassei a questão para a turma que, em unanimidade, aceitou a proposta de Bruno. Esta, dentre outras situações, exigiram que os alunos pensassem acerca da produção sonora, defendendo seus pontos de vista.

A aluna Fernanda valorizou o fato de, durante a oficina, aprender "como se faz a música”. Comentou, durante as entrevistas, acerca deste trabalho que envolvia a exploração de sons, o uso de instrumentos que eram desconhecidos por eles - nos quais ela passou a observar o "barulho” produzido - dentre outros aspectos, ressaltando que aprendíamos neste processo sobre o que é e como se faz a música: "Eu acho que a gente aprende a música, o que é a música. A gente aprende a ouvir, a tocar e a saber como a gente faz a música”. (Fernanda - registro audiovisual). Em sua fala percebe-se a valorização deste processo que considera o 
“pensar” em sala de aula, o aprendizado de uma construção de relações entre os sons, o "saber” como se faz uma música.

Alguns apontamentos das crianças demonstraram também o quanto elas gostaram de entrar em contato com instrumentos diversos, manuseando-os e explorando sonoridades dos mesmos. Quando questionada a respeito do jogo que mais gostou, Fernanda respondeu: “foi quando fez a roda e colocou os instrumentos no meio. Porque a gente pegou os instrumentos e começou a tocar. Isso foi muito legal, porque é muito legal conhecer um instrumento novo e tocar [...] ouvir o barulho” (Fernanda - registro audiovisual). Fernanda estava se referindo ao jogo "Floresta e seus bichos", em que as crianças puderam escolher os instrumentos colocados no centro da roda e iniciar uma improvisação livre por meio deles. A respeito deste, ela fez as seguintes anotações em seu protocolo:

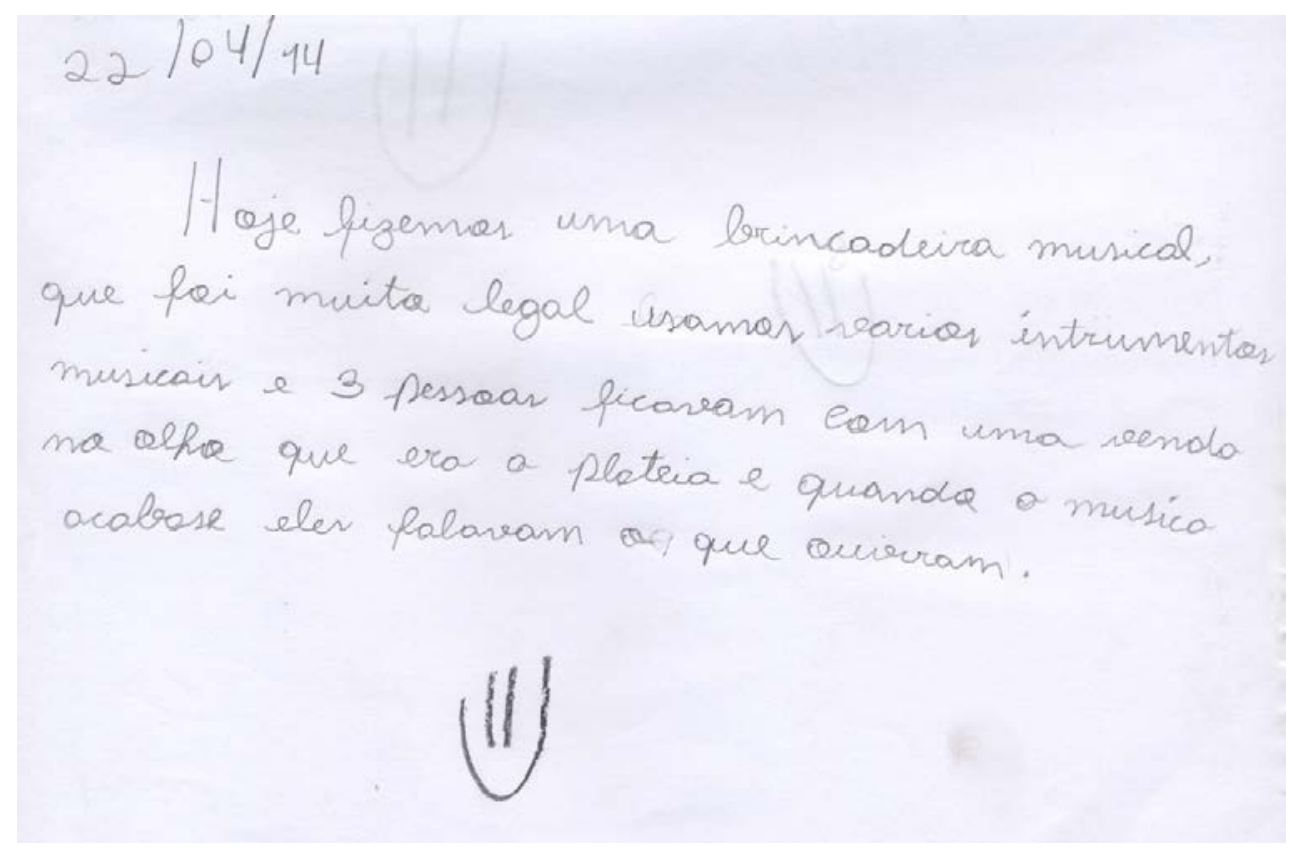

Figura 10 - Protocolo de Fernanda.

Conhecer um instrumento novo (como relatou Fernanda), descobrir o próprio corpo como um instrumento (ponto indicado por Tiago), dentre outras questões relacionadas ao manuseio destes “materiais” que eram utilizados nas criações, foram apontamentos erguidos pelas crianças como importantes em suas relações com a música. 
Pereira (2012) acredita que os materiais usados pelos jogadores são fontes para exploração e invenção no ambiente do jogo. No caso dos jogos da Oficina de Música, estes materiais consistiram em instrumentos musicais, convencionais ou não, além do uso do próprio corpo como fonte sonora.

\begin{abstract}
Além das abordagens de Huizinga e Caillois, observa-se também que há estudos que o qualificam [o jogo] como um espaço no qual são engendradas a exploração e a invenção com os materiais escolhidos pelos jogadores, como afirmam Brougère, Bruner, Ryngaert e Stephen Nachmanovitch. Nesse sentido, esse campo exploratório proporciona aos jogadores um leque de experiências que podem levá-los a ações na esfera da criação (PEREIRA, 2012, p. 82).
\end{abstract}

Gabriela, aluna do $1^{\circ}$ ano, quando questionada acerca do que havia aprendido sobre música durante os jogos, respondeu: "instrumentos que a gente não sabia que existia” (Gabriela - registro audiovisual). Esta e outras falas das crianças revelam também suas posturas ante os materiais que estavam sendo explorados, descobertos e utilizados para suas criações. Pedro, por exemplo, esteve investigando, manuseando, descobrindo possibilidades e recursos sonoros de um bongo e de um apito durante a criação de uma composição. Em determinado momento, Pedro chamou a pesquisadora e exclamou: "saiu uma coisa aqui! Eu vi uma coisa!" (Pedro - registro audiovisual). O aluno estava se referindo a "bolinha" que havia dentro daquela fonte sonora e que se movia no interior do apito cada vez que Pedro assoprava-o. Este momento de exploração e descoberta pareceu muito importante a Pedro que, após, registrou-o em seu protocolo. 


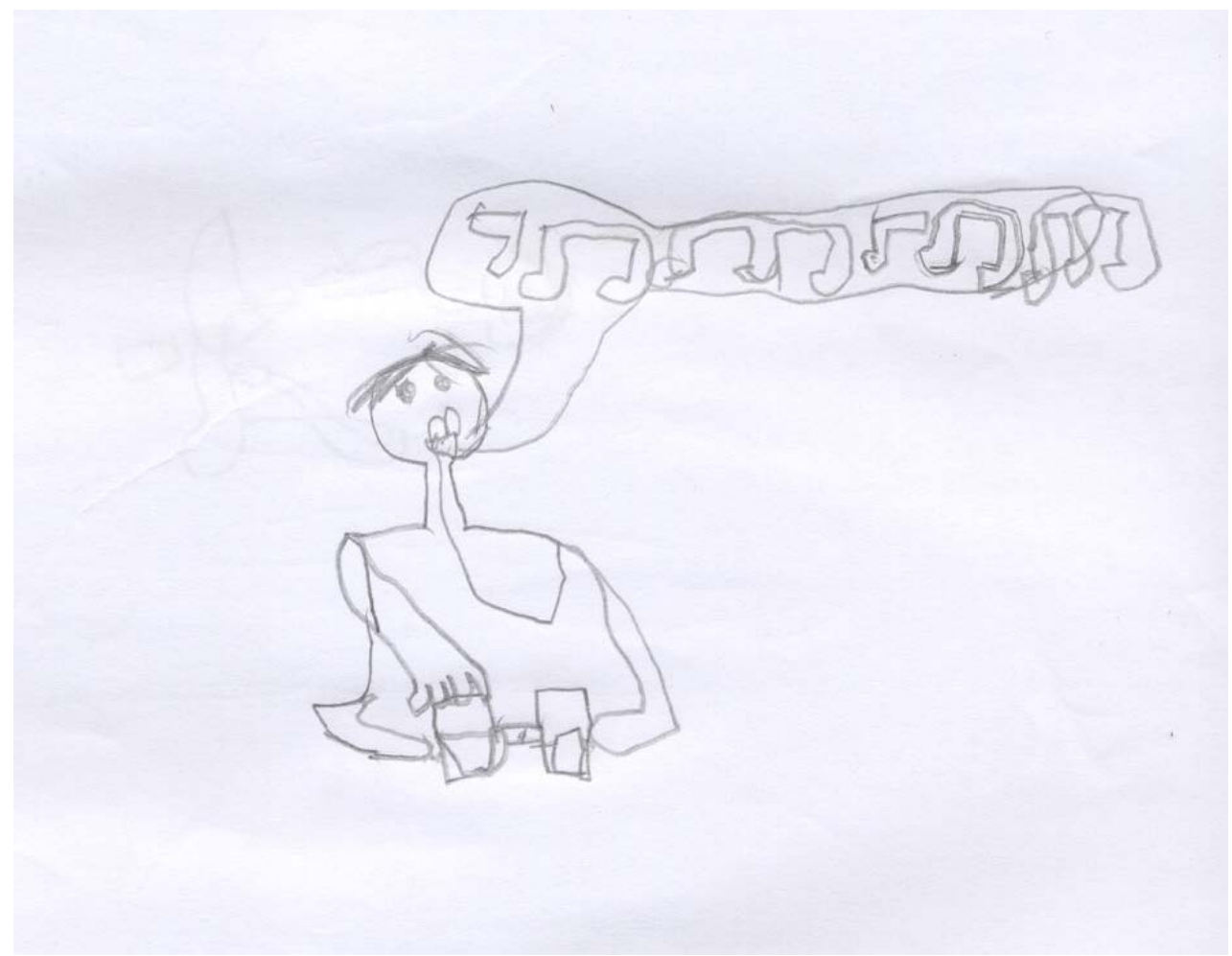

Figura 11 - Protocolo de Pedro.

A partir dos relatos expostos anteriormente e das observações da pesquisadora durante os encontros realizados, pôde-se perceber o interesse das crianças pelos momentos em que lidavam com os instrumentos musicais (convencionais ou não), pois aqueles instantes possibilitaram exploração livre das fontes sonoras existentes em sala, pesquisas e descobertas timbrísticas em instrumentos (alguns ainda desconhecidos pelos alunos), além do reconhecimento do próprio corpo como um instrumento musical. Fazer uso destes materiais sonoros em suas próprias criações, aprendendo a "inventar músicas" durante o manuseio/utilização deles, consistiu em outro aspecto valorizado pelas crianças.

Na realização de outras entrevistas em grupo, os alunos também foram questionados a respeito do que aprenderam sobre/de música durante os jogos. Bruno indicou que aprendeu a “inventar ritmos” (Bruno - registro audiovisual). Marcos, em seguida, falou que aprendeu a “inventar músicas” (Marcos - registro audiovisual). Bruno concluiu dizendo: “aprendemos com os outros... outros sons!” (Bruno - registro audiovisual).

Os diferentes relatos valorizaram o aprender a inventar, fosse o aprendizado de “inventar músicas” ou "inventar ritmos”, como os alunos Marcos e Bruno destacaram. O 
“aprender com os outros” foi aspecto novamente levantado (assim como no exemplo dado por Marcos, que destacou ter aprendido o “som de leão” com Tiago), desta vez por Bruno, que também afirmou ter aprendido com os outros novos sons.

Isabela, aluna do $2^{\circ}$ ano, relatou: “eu aprendi música de sons de árvore, de animais e de água” (Isabela - registro audiovisual). Os sons realizados durante o jogo "Floresta e seus bichos”, por meio de uma livre improvisação, estavam sendo citados pela aluna. Ela os representou, em sua fala, considerando-os música: “música de sons de árvore”, "música de sons de animais” e "música de sons de água”. A aluna havia se engajado nos processos de criar sonoridades para uma floresta, explorando e criando sons por meio da voz e de instrumentos convencionais. Em um processo de improvisação, espaço comunicacional/dialógico, Isabela interagia com as outras crianças, representando uma floresta por meio de sons. Para tal representação, os alunos buscavam “imitar” o som da água, por exemplo, tanto pelos referenciais que já possuíam quanto pela atenção aos sons que os outros alunos estavam criando. Neste sentido, as explorações sonoras de um jogador forneciam pistas ao outro, que também se envolvia em novas (re)criações.

\begin{abstract}
A imitação tímbrica acontece mesmo quando há dificuldade em sua execução, pois a escuta fica mais ativa e a atenção, no todo, fica mais efetiva no fluxo do jogo. Cada gesto e cada maneira de fazer o som se complementa, e um timbre dado por um jogador dá pistas para a criação de outro timbre. Em uma progressão exponencial, as nuances expressivas que aparecem se esgotam somente quando os jogadores já não querem mais jogar (PEREIRA, 2012, p. 141).
\end{abstract}

João, após os apontamentos acima - erguidos por Isabela na entrevista - exclamou: “eu aprendi a tocar piano!” (João - registro audiovisual). O aluno havia, também durante o jogo "Floresta e seus bichos", escolhido o piano para realizar uma improvisação livre. Por meio de suas falas em aula, entrevistas ou ainda em seus protocolos, pôde-se constatar a importância deste jogo e deste momento de improvisação ao piano para o aluno, que permaneceu improvisando durante oito minutos na aula. A relação de João com a música será enfatizada mais a frente em um dos exemplos específicos que serão citados, tendo em vista tanto seu amplo desenvolvimento no percurso da Oficina quanto os argumentos que podem ser abarcados por meio de seu exemplo. Seu caso aponta para a defesa da música como fator de desenvolvimento, e não apenas como entretenimento (tendo em vista que no contexto escolar a música é, muitas vezes, destinada ao horário do recreio, às festas infantis e às apresentações escolares, e não à sala de aula). 


\section{7 “EU APRENDI NOVOS JOGOS”: A AMPLIAÇÃO DE UM REPERTÓRIO}

Aprender com jogos, segundo as próprias crianças, possibilitou conhecer novas brincadeiras, ampliando um "repertório" pessoal. Para além, citaram que gostaram de aprender novos jogos devido ao fato de poderem ensinar para outras pessoas estes modelos ainda desconhecidos, transmitindo-os, inclusive, para membros da própria família. O diálogo abaixo, que surgiu durante uma entrevista, ressalta o ponto de vista das crianças e os motivos pelos quais gostaram da prática dos jogos em sala de aula:

\footnotetext{
Marcos: legal. Porque todo mundo aprende coisas que a gente não sabe e brincadeiras novas.

Luana: muito legal porque eu... Às vezes eu aprendo um jogo que se faz com a família em casa [aluna já havia ensinado para a irmã mais nova o acompanhamento rítmico dos copos do jogo “Bate o Monjolo”].
}

Bruno: porque a gente aprende novos jogos, mais brincadeiras.

Marcos: [brincadeiras] que a gente não sabe.

A aluna Isabela também indica estes fatores, comentando: "eu acho que assim: que se têm mais pessoas, aí as pessoas aprendem mais jogos e podem ensinar pra outras pessoas que não conhecem” (Isabela - registro audiovisual). Ela compartilhou ainda que nunca havia visto uma oficina com jogos musicais, em que se toca "um monte de coisa” e, simultaneamente, brinca-se. Isabela afirmou: "Eu acho legal. Eu nunca vi assim com jogos musicais [...] Porque nós tocava um monte de coisa e nós brincava” (Isabela - registro audiovisual).

Outro ponto interessante é que dentre estes novos jogos aprendidos, constam jogos criados pelas próprias crianças e compartilhados entre si - já que toda a turma experimentou e jogou os modelos inventados pelos diferentes grupos. Logo, esta ampliação de repertório se deu por meio de criações próprias e de invenções de outros colegas.

Vale destacar também que os jogos levados pela pesquisadora serviram como referência para que os alunos criassem os seus. O subcapítulo De um jogo, outro jogo consta como um dos tópicos do trabalho de Pereira (2012), em que as adaptações/variações de jogos 
propostas pelos alunos participantes de sua pesquisa são abarcadas. O autor aborda as recriações dos alunos, enfatizando que os jogos realizados em sala tiveram também o intuito de possibilitar referências aos estudantes para a criação de outros jogos.

\footnotetext{
Durante as aulas, os jogos sempre foram realizados com o intuito de provocar nos estudantes o prazer de descobrir os procedimentos de produção vocal e a reflexão sobre esses procedimentos, e também de propiciar referências para a criação de outros jogos. Eles foram inspiradores para a constituição de novos modelos de situação lúdica, tanto no decorrer das atividades em si, quanto na ocasião dos protocolos (PEREIRA, 2012, p. 174-175).
}

Embora em contextos distintos, percebeu-se que os alunos participantes de ambas as pesquisas se envolveram na recriação de jogos a partir dos modelos trabalhados em sala. $\mathrm{Na}$ Oficina de Música, por exemplo, observou-se que os jogos criados pelas crianças continham, muitas vezes, as mesmas personagens existentes nos jogos que haviam sido levados pela pesquisadora. O “jogo pega-pega animal”, criado pelas alunas Fernanda, Larissa e Gabriela, foi desenvolvido com base no "pega-congela sonoro". Logo, a estrutura base do "pegacongela sonoro”, apresentado pela pesquisadora, manteve-se, com um pegador que perseguia e “congelava” os outros jogadores. Além disso, as alunas propuseram também a inserção de sons de animais - sons trabalhados, anteriormente, no jogo "Floresta e seus bichos" e nas variações deste.

“Música”, modelo criado pelos alunos Pedro, Luana e Patrícia, também sugeriu a imitação de sons de animais. Neste jogo, inclusive, a personagem principal consistia em um caçador "equipado" com uma flecha sonora. O caçador e sua flecha foram elementos retirados das variações do jogo "Floresta e seus bichos".

Deste modo, nota-se que os jogos trabalhados em sala serviram também como inspiração e referência às crianças para a invenção de seus modelos, possibilitando a ampliação de um repertório de jogos através de suas próprias criações. A importância atribuída pelas crianças ao fato de poderem criar jogos será tratada no tópico a seguir.

\section{8 “EU GOSTO DE INVENTAR OS MEUS PRÓPRIOS JOGOS”: O VALOR ATRIBUÍDO ÀS CRIAÇÕES}


O ato de "inventar o próprio jogo" consiste em outro ponto bastante valorizado pelas crianças no decorrer do processo. Os alunos defenderam que gostaram de criar jogos, experimentar os jogos criados pelos outros colegas - ressaltando o valor destes por serem inéditos - trabalhar em grupos durante as criações, interagir com pessoas de outras idades/turmas, compartilhar ideias com outros alunos no momento em que estão pensando a estrutura de seus jogos, dentre outras questões. Larissa, por exemplo, afirmou que gostou de criar o jogo com seu grupo "porque a gente se divertiu muito criando um jogo que ninguém nunca jogou”. (Larissa - registro audiovisual). Este ineditismo adquiriu ênfase no relato de vários alunos.

Os alunos Tiago e Gabriela, quando questionados acerca do jogo que mais haviam gostado, responderam:

Tiago: eu gostei mais de todos os jogos! Foi muito legal. Eu aprendi jogos novos também.

Gabriela: eu gostei que os outros inventaram jogos porque eu gosto de inventar os meus próprios jogos.

O gosto por aprender jogos novos e por inventar os próprios jogos, usando-se “a cabeça” e "a imaginação”, foram temas recorrentes nas entrevistas. O diálogo abaixo - que emergiu do questionamento do por que haviam gostado de criar seus próprios jogos - também pode ilustrar as questões apresentadas.

Bruno: legal.

Pesquisadora: por quê?

Bruno: pôde usar a imaginação.

Marcos: usar a cabeça.

Luana: eu também gostei. Porque a gente aprendeu alguns [jogos] e a gente teve oportunidade de criar outros.

O processo de criar jogos foi tão significativo para as crianças que, quando a pesquisadora perguntava a respeito dos jogos realizados na Oficina de Música, pedindo que indicassem os seus preferidos, suas respostas estavam relacionadas ao jogo que o próprio aluno havia criado ou, ainda, ao jogo que outros participantes inventaram. Bruno, Luana e Marcos, por exemplo, responderam: 
Bruno: o meu, claro! [risos]

Luana: o meu jogo.

Marcos: foi o do Bruno.

Em outra entrevista, por exemplo, solicitou-se que as crianças falassem acerca de um jogo que ainda lembravam, descrevendo, preferencialmente, o primeiro que viesse à memória. Bernardo, então, começou a compartilhar as regras de um dos jogos quando, de repente, Fernanda exclamou: “Ah, foi meu jogo!” (Fernanda - registro audiovisual). A satisfação da aluna ao perceber que Bernardo lembrara seu jogo foi notória, tanto por sua resposta enfática quanto pelo seu sorriso. Bernardo, ainda, afirmou: "não é um jogo que eu conheço, mas aprendi. Um jogo novo. Todos nós aprendemos um jogo novo”. (Bernardo - registro audiovisual). Ainda que a pesquisadora não houvesse observado a alegria da aluna em ter seu jogo narrado por Bernardo, ela mesma fez comentários a respeito. Quando questionada acerca do motivo pelo qual gostou de criar um jogo, ela respondeu: “eu gostei porque a gente cria esse jogo e depois as pessoas brincam e adoram esse jogo! E é bem legal aí sabe: 'Ai, a Fernanda que criou esse jogo. Ai, bem legal. Eu gostei desse jogo. É bem divertido’ [referindo-se ao que os outros alunos comentam]” (Fernanda - registro audiovisual).

Pedro também gostou de criar um jogo e, antes do término da aula, desejou escrever em seu protocolo as regras e as personagens de seu jogo. Entretanto, sem muito domínio da escrita (por ser um aluno do $1^{\circ}$ ano), não conseguia fazer as anotações almejadas. A aluna Luana, componente de seu grupo, prontamente resolveu ajudar: passou a escrever para Pedro o que ele solicitava. Com esta interação e atitude colaborativa, fez-se o registro abaixo: 


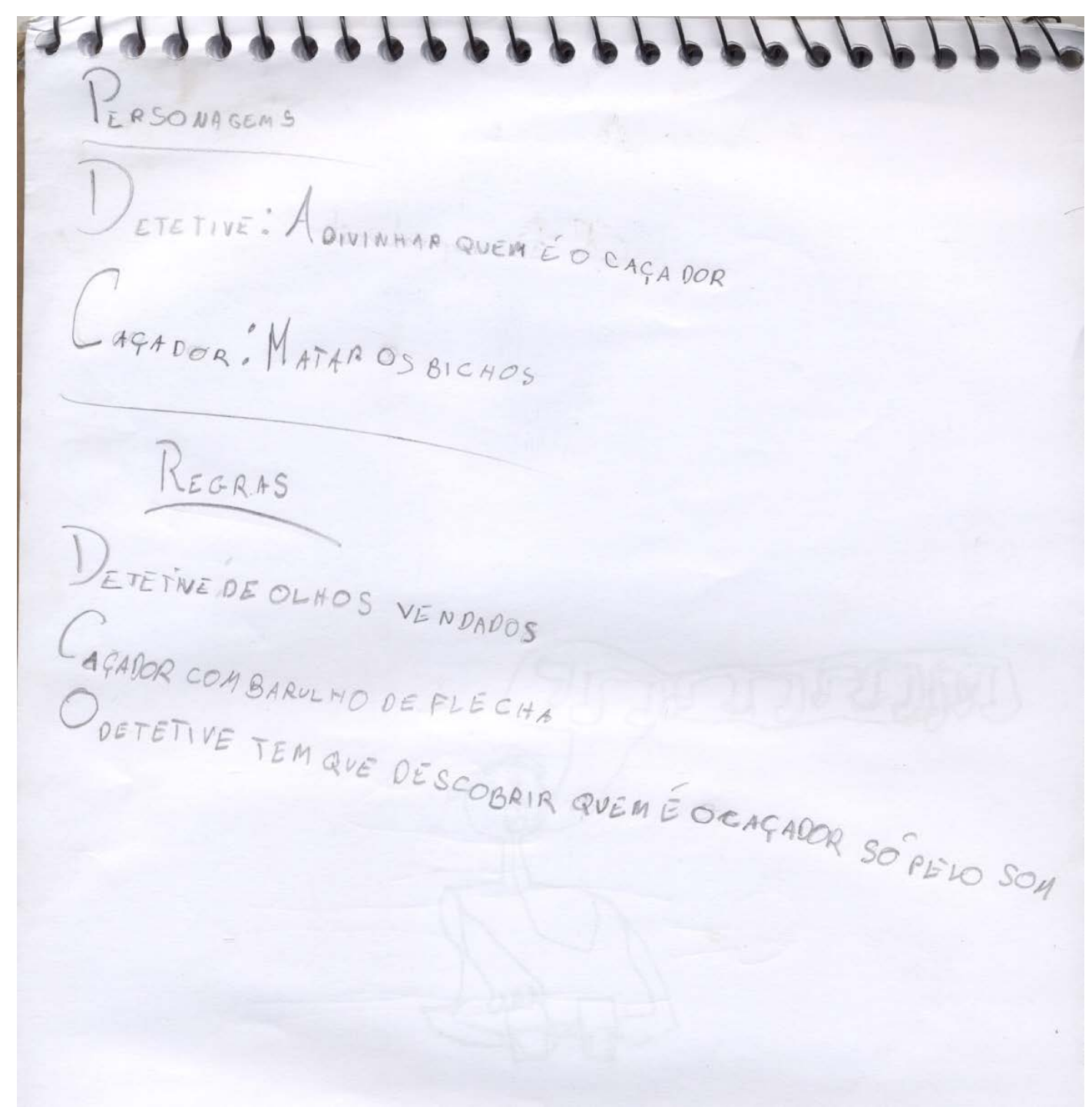

Figura 12 - Protocolo de Pedro referente ao jogo criado por seu grupo.

A possibilidade de criar jogos foi valorizada pelas próprias crianças. Os principais argumentos que os alunos expuseram acerca da importância desta experiência foram: (1) a satisfação e diversão que há em criar e experimentar jogos “que nunca ninguém jogou”; (2) o gosto por momentos em que eles podem inventar, "usar a cabeça”, "usar a imaginação”; (3) a possibilidade de interação entre os participantes da Oficina através dos processos de criação em grupos.

Vale lembrar que Koellreutter (apud BRITO, 2011) enfatizava a importância da criação até mesmo em relação à invenção de jogos pelas próprias crianças. Os modelos de improvisação criados pelo educador não deveriam ser considerados como “fórmulas”, mas 
como ponto de partida para um fazer musical criativo (BRITO, 2011). Deste modo, "Koellreutter sempre estimulou os alunos [adultos/educadores] a criar outros modelos, adequados à sua realidade de trabalho, e sugeria também que as crianças os criassem” (BRITO, 2011, p. 95).

\section{9 “A GENTE APRENDE A CONVIVER COM OUTRAS PESSOAS”: JOGAR PARA} INTERAGIR!

As falas das próprias crianças a respeito das relações estabelecidas durante os jogos consistem em importantes fontes, sobre as quais me apoio, para argumentar as contribuições dos jogos de improvisação na educação musical, defendendo-os não apenas para o desenvolvimento de capacidades musicais, mas também para a formação humana. Dentre muitos relatos e opiniões, os alunos ressaltaram que gostaram de criar jogos por terem conhecido novos amigos neste processo, além de terem conversado com alunos de outras turmas - com os quais, comumente, não falavam. Seguem dois importantes relatos sobre estas questões.

\footnotetext{
Fernanda: eu gostei de criar um jogo porque eu conheci amigas novas e foi muito mais legal. E também a gente criou o jogo e brincou depois [experimentamos os jogos de cada grupo em sala]. E no meu grupo já tinha pessoas que quando você falou pela primeira vez que a gente ia inventar um jogo, já tinha pensado no jogo e acabou ajudando a gente a fazer isso. Aí foi muito legal.

Patrícia: é legal porque eu fiquei com pessoa do $1^{\circ}$ ano: pessoa do $1^{\circ}$ ano eu não consigo falar. Porque eles vão achar "ai que estranho! O $3^{\circ}$ ano falar com o $1^{\circ}$ ano". Aí vai pra outro lugar. Aí foi legal. E com $4^{\circ}$ ano também. Eu consegui conversar com alguém do $4^{\circ}$ ano, que foi a Luana, né. Aí eu consegui né. Aí foi legal.
}

Não apenas na fala de Fernanda, mas também em seu protocolo, consta o gosto pela criação de um jogo em grupo pelo fato da aluna ter conhecido novas amigas. Segue, abaixo, o registro da aluna sobre este momento. 
$06 / 05 / 14$

e depair nos formamas grupos de 3

e fai muita legal conhei 2 amigas

e is agente tinha que criar

un jaga.

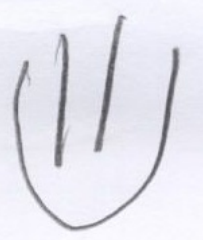

Figura 13 - Protocolo de Fernanda.

Já o relato de Patrícia permite perceber, inclusive, a fragmentação gerada por um modelo de escola, que permanece perpetuando, em que há uma divisão por turmas/idades ${ }^{34}$,

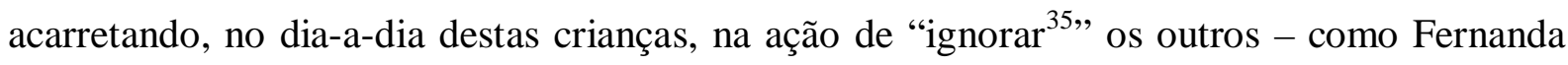
expõe em outro momento. De acordo com muitas falas das crianças (que tornaram este um dos assuntos enfaticamente debatidos nas entrevistas), não há interação entre os alunos de diferentes faixas etárias na escola. A "cena" que frequentemente pode ser observada, segundo as crianças, é a de alunos do $5^{\circ}$ ano que não falam com os do $4^{\circ}$ ano; alunos do $4^{\circ}$ ano que não

\footnotetext{
${ }^{34}$ Algumas falas das crianças em relação à divisão por turmas/idades serão expostas ainda neste tópico, com vias a defender os jogos de improvisação, no contexto da Oficina de Música, como espaços para a interação e a convivência. Entretanto, o tópico a seguir será destinado, mais especificamente, a uma discussão acerca deste assunto, considerando tanto as falas das crianças quanto relatos da professora Denise para fundamentar ainda mais esta questão.

${ }^{35}$ Termo usado pelas próprias crianças durante a entrevista.
} 
conversam com os do $3^{\circ}$ ano; e assim por diante... A turma que está "um ano acima”, portanto, não estabelece diálogos com aqueles que "estão abaixo”. Logo, os jogos de improvisação, no contexto da Oficina de Música, permitiram uma interação entre crianças que, comumente, "ignoram-se” na escola.

De acordo com Pereira (2012), o jogo é gerador de vínculos. O autor ressalta as interações estabelecidas no ato de jogar, afirmando que os sujeitos interatuam, até mesmo, com "inimigos” da vida cotidiana.

O jogo é também um gerador de vínculos. Ele possibilita o encontro com o outro, estabelecendo uma rede de sentidos entre os jogadores, criando um lugar diferenciado no qual os sujeitos e o jogo se tornam um. Os liames ali presentes também podem ser ficcionais. Joga-se, muitas vezes, com sujeitos que na vida cotidiana são “inimigos”, mas na situação lúdica se tornam parceiros, pois no jogo todas as ações são realizadas a partir de algum tipo de interação (PEREIRA, 2012, p. 79).

Para Patrícia (aluna do $3^{\circ}$ ano), a Oficina foi extremamente significativa, tendo em vista que ela, segundo suas próprias palavras, conseguiu conversar com uma pessoa do $1^{\circ}$ ano e com outra do $4^{\circ}$ ano. Além disso, vale ressaltar que Luana, aluna do $4^{\circ}$ ano, também comentou acerca da amizade desenvolvida com Patrícia. Logo após os primeiros encontros, ambas chegavam juntas à sala de aula, sentavam uma ao lado da outra, ficavam nos mesmos grupos (quando a turma era dividida para os trabalhos em grupo), dentre outras ações observadas. Tanto Patrícia quanto Luana, sendo entrevistadas em momentos distintos, indicaram que a Oficina foi importante por terem feito novas amizades.

A divisão em turmas é uma característica que pareceu incomodar muitos alunos principalmente Patrícia e Fernanda, que retomam o assunto em diversos momentos da entrevista. Quando a pesquisadora perguntou se houve algum aprendizado durante os jogos na Oficina, além dos aspectos musicais trabalhados, surgiu o seguinte diálogo:

Patrícia: a gente aprende além de música. A gente aprende jogos novos... E a gente aprende a brincar juntos! Porque tem pessoa que a gente... a gente só brinca com uma, a gente só brinca sozinho. A gente aprende a brincar com os amigos!

Fernanda: a gente aprende brincadeiras novas, como ela disse. E também, aprende a conviver com outras pessoas com a idade diferente de você. Porque se você vê, tem várias pessoas que só brinca, tipo: $5^{\circ}$ ano brinca com $5^{\circ}$ ano, $5^{\circ}$ ano ignora $04^{\circ}$ ano... Tipo, uma coisa muito louca.

Patrícia: igual o $4^{\circ}$ ano: eles falam... [começa a citar um exemplo]: As minhas amigas da perua são do $4^{\circ}$ ano. Eu pedi para brincar de esconde-esconde com ela, que eu 
adoro brincar esconde-esconde! Ela disse por que não: porque eu era do $3^{\circ}$ ano. E eu não podia brincar!

Fernanda: é. Algumas pessoas sofrem bullying com isso. E a gente aprende a conviver com outras pessoas.

Não apenas Patrícia, mas também Fernanda aponta a importância dos jogos por terem possibilitado uma interação com pessoas de diferentes idades. Além disso, ressalta o aspecto já tratado por Patrícia, indicando que, na escola, os alunos mais velhos não falam com os mais novos - acreditando que muitas crianças sofram bullying. Encerrou sua fala destacando, novamente, o fato de ter aprendido a conviver com outras pessoas durante a Oficina de Música. Após alguns instantes, Bernardo deu continuidade ao assunto, comentando que aprendemos “a fazer novas brincadeiras e fazer novos amigos” (Bernardo - registro audiovisual). Patrícia respondeu e concluiu o diálogo: “É... combinou né? A gente aprende jogos novos e a gente faz amigos novos!” (Patrícia - registro audiovisual).

\subsection{0 “ESSE NEGÓCIO DE MISTURAR AS IDADES TINHA QUE TER MAIS": A OFICINA JOGOS MUSICAIS COMO ESPAÇO PARA INTEGRAÇÃO}

A Oficina de Música foi muito valorizada pelas crianças por proporcionar um convívio entre alunos de diferentes idades. Este foi um dos aspectos enfatizados em diversos momentos, refletindo em comentários realizados durante as entrevistas (alguns já apresentados no tópico anterior desta dissertação). Muitas vezes, independente se as perguntas feitas às crianças eram relacionadas ao jogo, ao aprender brincando, ao processo de criar novos jogos, dentre outras questões, elas retomavam um debate a respeito da "mistura de idades” na Oficina.

A professora Denise, que acompanhou a prática da pesquisa-ação, também considerou este fator como um ponto muito importante deste trabalho. Ela comentou acerca da proposta da Escola de Aplicação de oferecer oficinas diversas aos alunos, destacando o fato de se propiciar às crianças momentos de escolha acerca do que desejam aprender, além das oficinas permitirem esta integração entre estudantes de diferentes idades. 
Eu acho que é fantástico assim. É mais um momento de escolha. Deveria ter muito mais momentos como esse né. E de misturas das idades, né? Isso eu acho... eles são muito compartimentados, né. O conhecimento já é compartimentado né, as idades [são] compartimentadas (Denise - registro audiovisual).

A professora citou dois exemplos para defender esta integração. Primeiramente, falou sobre um passeio que organizou com a turma do $7^{\circ}$ ano da escola, explicando que 80 crianças poderiam participar. Tendo em vista que restaram 16 vagas, ela ofereceu-as para uma turma do $9^{\circ}$ ano, acreditando que esta ficaria contente com a oportunidade de usufruir do passeio. Entretanto, ao oferecer ao $9^{\circ}$ ano, impressionou-se com a reação da turma. Os alunos passaram a comentar: “Ah, mas é com o $7^{\circ}$ ano?” (Denise - registro audiovisual). A professora destacou seu ponto de vista, acreditando que este "estranhamento" não deveria existir, mas sim o entendimento de que eles são colegas. Neste caso, os alunos do $9^{\circ}$ ano, segundo a professora, deveriam compreender que estariam fazendo um passeio com seus colegas mais novos: "eles começaram um estranhamento assim, sabe? E não devia ter esse estranhamento né? É com os colegas, mais novos...” (Denise - registro audiovisual).

Outro exemplo citado pela professora foi a respeito da escola Amorim Lima ${ }^{36}$ e da abordagem dessa escola em relação às "inter-idades”. A partir disto, Denise compartilhou os motivos pelos quais gosta das oficinas na Escola de Aplicação:

Acho que falta muito esses momentos. Por isso que eu gosto muito das oficinas. E é
uma coisa que eles escolhem né [...] mas esse negócio de misturar as idades tinha
que ter mais. Escolhas e misturar [as idades]. E você vê o efeito disso. O Marcos,
por exemplo [referindo-se a mudança de comportamento deste aluno] (Denise -
registro audiovisual).

A professora encerrou sua fala comentando sobre o aluno Marcos, pois o "Marcos da Oficina de Música”, segundo ela, era “outro Marcos”. Denise compartilhou que ficou impressionada com o comportamento deste aluno durante os encontros, tendo em vista sua agressividade em outros ambientes da escola. Na opinião da professora, tal mudança se deu também pela “mistura de idades”. Ao invés de Marcos, aluno do $5^{\circ}$ ano, agir agressivamente -

\footnotetext{
${ }^{36}$ Escola Municipal de Ensino Fundamental Desembargador Amorim Lima é uma escola pública localizada na cidade de São Paulo. No ano de 2003, a escola buscou a implantação do "Projeto Fazer a Ponte" (originalmente da Escola da Ponte, de Portugal) e, a partir do ano de 2004, pôde contar com "um Projeto Pedagógico bastante diferente do que se conhece nas escolas públicas tradicionais” (EMEF DESEMBARGADOR AMORIM LIMA, 2014). Maiores informações podem ser encontradas no site da escola: "http://amorimlima.org.br”
} 
como era de costume com outros alunos de sua faixa etária - ele conviveu com crianças mais novas, formou grupos com elas, participou dos processos de criação e ajudou-as no que foi preciso, dentre outras atitudes que não condiziam com sua postura fora da Oficina. Especificidades a respeito deste aluno serão narradas com mais profundidade posteriormente, considerando as mudanças observadas em seu comportamento e a importância de defendermos, por meio deste exemplo, o espaço da música, do jogo e do criar para a formação humana.

As críticas a este modelo escolar que fragmenta e separa as crianças por idades foram feitas tanto pela professora Denise quanto pelas próprias crianças. Ao perguntar aos alunos se preferiam trabalhar individualmente ou em grupo, a questão da “mistura de idades” na Oficina e de uma divisão em outros momentos foi, novamente, exposta. No diálogo que seguirá, podese observar a preferência destes estudantes pelo trabalho em grupo, a possibilidade de se estar em grupo no recreio após tal integração durante as aulas de música, além da exposição de uma divisão de idades que ocorre na escola até mesmo no horário do recreio.

\footnotetext{
Pesquisadora: vocês preferem trabalhar individualmente ou em grupo?

Bernardo, Fernanda e Patrícia [em resposta simultânea]: em grupo!

Pesquisadora: todo mundo em grupo? Por quê?

Patrícia: porque é mais divertido.
}

Fernanda: porque a gente conhece pessoas novas.

Patrícia: e a gente não fica tipo assim, na hora do recreio: “ai, na aula de artes foi bem legal trabalhar sozinho, então vou brincar sozinho aqui também pra ver se é legal.” Não. Isso é chato. Aí no recreio você também pode fazer tipo igual na Oficina: “vamos trabalhar em grupo que é melhor, né?” Porque você pode ver que a brincadeira tá legal, que a gente não precisa brincar sozinho.

Pesquisadora: entendi. Então o que você faz na aula de artes faz você pensar no recreio?

Patrícia: é!

Após algum tempo, as crianças retomaram este assunto. A pesquisadora, então, colocou uma nova questão.

Pesquisadora: no recreio de vocês, vocês têm conversado com as pessoas dos outros anos da aula de música? 
Patrícia: não, porque é separado...

Fernanda: não.

Patrícia: sabe por quê? Porque é separado. $\mathrm{O} 3^{\circ}$ ano, o $1^{\circ}$ e o $2^{\circ}$ é tudo junto. $\mathrm{O} 4^{\circ}$ e o $5^{\circ}$ é separado do $3^{\circ}$ [ano do qual a aluna faz parte]. E outras pessoas do $1^{\circ}$ ano eu não encontro nem do $2^{\circ}$. Então não dá [com expressão facial de insatisfação].

Barbosa (2007), ao estudar as relações de poder disciplinares na escola com base na obra de Foucault (1999), também fala a respeito desta divisão entre alunos em momentos de lazer. A autora afirma que "no horário dedicado ao lazer, os grupos não se misturam. Os professores conversam numa sala específica, os funcionários em outra, os estudantes ficam no pátio, em geral brincam por série, tamanho, sexo, faixa etária” (BARBOSA, 2007, s/p).

Foucault (1999), refletindo acerca desta divisão e “organização de um espaço serial”, revelou as tentativas de vigilância e controle que estavam por trás de tais propostas. Além disso, apontou que esta organização serial "tornou possível o controle de cada um e o trabalho simultâneo de todos. Organizou uma nova economia do tempo de aprendizagem. Fez-se funcionar o espaço escolar como uma máquina de ensinar” (FOUCAULT, 1999, p. 126).

As vivências na Oficina de Música geraram reflexões a respeito desta separação por idades, desta fragmentação existente e decorrente de um modelo escolar que permanece em voga - apesar das críticas de muitos pesquisadores (como as citadas acima e também no capítulo 1 desta dissertação), de professores (como, por exemplo, da própria professora Denise) e até mesmo das crianças. Desta forma, acredita-se que as experiências em jogos de improvisação na Oficina de Música colaboraram para a formação de sujeitos críticos e reflexivos, destacando-se, neste tópico, as reflexões e críticas das crianças em relação ao modelo de escola vigente.

\subsection{1 “A GENTE FEZ NOVOS AMIGOS”: O TRABALHO COLABORATIVO E OS LAÇOS AFETIVOS POR MEIO DA EDUCAÇÃO MUSICAL}

Os trabalhos em grupo foram elogiados pelos alunos, que enfatizaram, dentre outras questões, as novas amizades criadas no ambiente da Oficina de Música. Questionados se haviam gostado de trabalhar em grupos, Fernanda respondeu: “eu gostei. Eu conheci pessoas 
novas, eu me diverti. Foi legal” (Fernanda - registro audiovisual). Nesta mesma entrevista, Bernardo comentou o motivo pelo qual gostou do trabalho em grupo: "Porque a gente consegue fazer uma nova amizade com outra pessoa que a gente ainda não conhece" (Bernardo - registro audiovisual).

Segue, abaixo, o protocolo de Bernardo, em que ele registra a si próprio (com o pandeiro) e o colega Tiago (com o atabaque) durante o jogo "Competição de instrumentos". Neste jogo, Bernardo (aluno do $4^{\circ}$ ano) compôs em dupla com Tiago (aluno do $1^{\circ}$ ano).

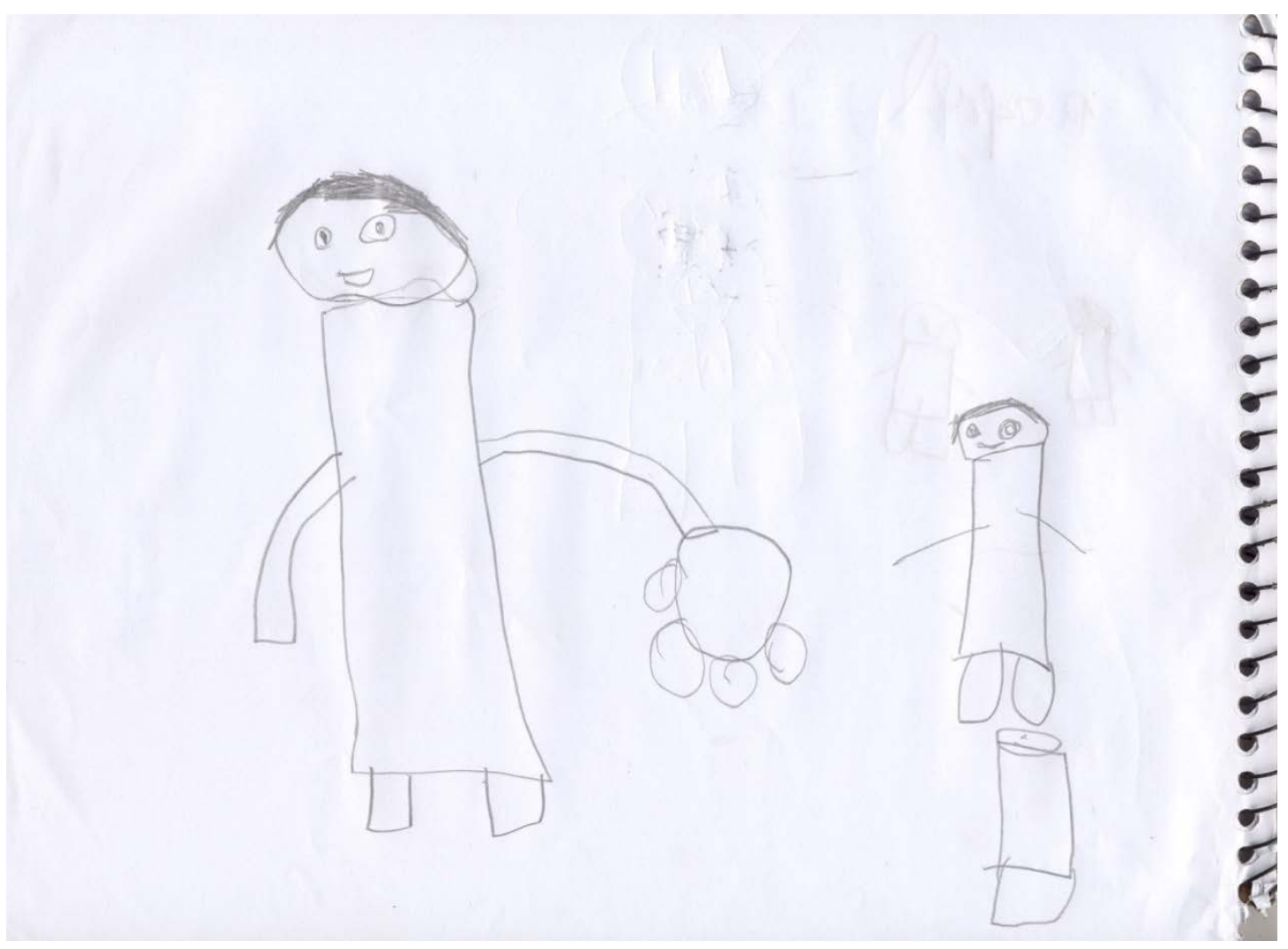

Figura 14 - Protocolo de Bernardo.

As relações estabelecidas entre os alunos, superando-se até mesmo a divisão por faixa etária, por exemplo, possibilitaram novos vínculos, novas amizades, fato constantemente relatado pelas crianças nas entrevistas. Nesta perspectiva, os jogos de improvisação podem ser compreendidos como geradores de vínculos (PEREIRA, 2012), à medida que relações interpessoais são desenvolvidas e aperfeiçoadas no ato de jogar. Ao jogar com os sons, fazendo música em grupo ou coletivamente, as características humanas também são 
qualificadas (BRITO, 2010), em um processo de trocas, de compartilhamento e de respeito mútuo.

Em outra entrevista, Tiago, Pedro e Gabriela disseram ter preferência pelo trabalho em grupo. A pesquisadora perguntou o motivo, e o seguinte diálogo emergiu:

\author{
Gabriela: porque sozinho você não tem nenhuma ideia e tem outros colegas mais pra \\ te dar mais atenção. \\ Pedro: ideias! \\ Gabriela: ideias... \\ Pedro: e orientação.
}

A aluna Luana também indicou seu ponto de vista, relacionando o trabalho em grupo ao jogo criado em sala. Afirmou que prefere "em grupo. Porque aí você tem um jogo melhor, com mais sugestões” (Luana - registro audiovisual). Marcos comentou que gosta de trabalhar das duas maneiras: em grupo e individualmente. Entretanto, explica que gosta do trabalho em grupo "porque cada um ajuda o outro. Assim... se o grupo, por exemplo, se o grupo fosse nós três [referindo-se aos que estavam sendo entrevistados]: a Luana poderia ajudar o Bruno, o Bruno me ajudar e eu ajudar a Luana" (Marcos - registro audiovisual). Pode-se citar ainda a fala de João, que havia criado um jogo juntamente ao aluno Bruno. Ele esclareceu que preferiu trabalhar em grupo "porque o Bruno... ele é importante. Porque ele escreve letra de mão ${ }^{37 ”, ~(J o a ̃ o ~-~ r e g i s t r o ~ a u d i o v i s u a l) . ~ D e s t e ~ m o d o, ~ p e r c e b e m-s e ~ a s ~ t r o c a s ~ e ~ a s ~ a t i t u d e s ~}$ colaborativas que emergiram em espaços de criação grupais.

De acordo com a aluna Gabriela, a Oficina foi "legal, porque a gente fez novos amigos” (Gabriela - registro audiovisual). Bruno e Marcos, durante um momento "livre” da entrevista, em que podiam falar a respeito da Oficina sem que houvesse o direcionamento de uma pergunta específica, comentaram:

Bruno: foi legal. Foi legal ter companhia né...

\footnotetext{
${ }^{37}$ Vale ressaltar que, devido ao diagnóstico de paralisia cerebral leve, João tem dificuldade para escrever. Assim, foi bastante importante para este aluno poder contar com a ajuda de Henrique na escrita das regras do jogo que haviam inventado.
} 
Marcos: ficar do lado dos amigos, conhecer outros amigos...

Os laços afetivos estabelecidos foram, portanto, valorizados. A integração, o ato de “conhecer outros amigos”, de "ter companhia”, a "mistura de idades”, dentre tantos outros aspectos, enfatizaram a necessidade e o anseio das crianças por espaços de trocas e convivência. Procura-se apontar, deste modo, a importância da

\footnotetext{
construção de espaços de convivência, no ambiente da educação, regidos por modos de comunicação que abarcam 'a diversidade da natureza das trocas, em que se fazem presentes os signos representativos ou intelectuais, mas principalmente os poderosos dispositivos do afeto’ (SODRÉ, 2006, p.13).” (BRITO, 2007, p. 4).
}

Por conseguinte, um trabalho voltado aos processos criativos na educação musical não deve visar apenas um "novo produto musical” - uma nova peça composta pelas crianças, por exemplo - mas também as interações e relações entre seres humanos, o desenvolvimento das capacidades humanas (BRITO, 2011; KOELLREUTTER, 1997d). Nas práticas de criação em grupo, "mais do que os produtos elaborados em aula, o foco são as aprendizagens colaborativas, de seres humanos que se relacionam fazendo música, que se escutam e que aprendem uns com os outros” (BEINEKE, 2012, p. 56).

\subsection{OS “NOVOS PAPEIS”}

Vale considerar, em meio às muitas contribuições já expostas, o jogo como espaço de eliminação dos "tradicionais papeis" da sala de aula: professor versus aluno. No capítulo 1 desta dissertação, o “mapeamento estratégico" e a "dicotomia professor e aluno” foram tópicos tratados e fundamentados, respectivamente, nos trabalhos de Gallo (1995) e Freire (1983). Na tentativa de superar tal divisão, o jogo cênico-musical foi pensado como recurso pedagógico. Portanto, algumas questões em relação aos “novos papeis” assumidos no ambiente do jogo são válidas.

Na Oficina de Música, o jogo “invadiu” o espaço da sala de aula. Na maior parte do tempo estávamos jogando e, quando não jogávamos, refletíamos acerca dos modelos vivenciados. Desta forma, a pesquisadora não assumia o papel de "professora”, mas de outra 
jogadora em meio à turma, representando, dentre tantas personagens, uma “abelha”, uma “fugitiva”, uma “caçadora”...

O papel de coordenação foi atribuído a diferentes pessoas no decorrer do processo. Quando o jogo a ser trabalhado, por exemplo, advinha do repertório da pesquisadora, ela o explicava para a turma e observava (enquanto jogava) se o jogo havia sido compreendido por todos. Entretanto, até mesmo nestes jogos os alunos assumiam os papeis de "comando" 38 (enquanto a pesquisadora fazia parte do grupo como mais um dos improvisadores, por exemplo).

Nos jogos criados pelas crianças, a coordenação do jogo era assumida por elas próprias. Cada grupo era responsável por explicar à turma o funcionamento de seu jogo, de maneira que todos pudessem brincar. Assim, conduziam a realização da aula, relatando se havíamos compreendido seus jogos ou se algo não estava como desejado. Em uma destas experiências, por exemplo, precisou-se repetir a realização de um jogo, tendo em vista que a turma não compreendeu as ações de uma das personagens. Assim, os próprios criadores do jogo cobravam em relação a isto, ressaltando as funções de cada papel e retomando/reiniciando o jogo.

Desta forma, os jogos em sala de aula, à medida que fazem emergir novos papeis, colaboram para a superação da dicotomia professor versus aluno. Segundo Spolin (2012a, p. 39), “é importante que o professor se torne um parceiro em jogo. Não se preocupe em perder o controle. Permita que os jogos trabalhem por você. Quando os alunos descobrem que ‘fizeram por si mesmos', o professor obteve sucesso”. Portanto, ao jogar, todos devem atuar e interagir em cena. Cabe ao professor livrar-se do desejo de dirigir e comandar a aula, compreendendo a importância deste momento de autonomia às crianças.

\footnotetext{
Uma prática voltada para a educação lúdica exige que o educador conviva com o inesperado, com a imprevisibilidade, que abra mão do controle absoluto, de sua onipotência, que abra espaço para auto-expressão e a criatividade de seus educandos, estimulando a sua participação efetiva no processo ensinoaprendizagem, trazendo aos educandos possibilidades de auto-conhecimento e autodesenvolvimento (PEREIRA, 2004, p. 82).
}

\footnotetext{
${ }^{38}$ Este termo faz menção às personagens que poderiam, por exemplo, incluir ou retirar sons/pessoas do jogo, reger a improvisação, decidir quais as funções dos novos jogadores, dentre outras ações de “comando” em cena.
} 


\subsection{3 “NO MEU LIVRO EU ESCREVI QUE EU INVENTEI UM JOGO BEM LEGAL”}

A fala que intitula este subcapítulo foi proferida por Patrícia durante uma entrevista. Ao compartilhar que havia escrito, em seu "livro", a respeito do jogo criado por seu grupo, a aluna estava se referindo ao registro realizado em um dos protocolos.

Para a aluna Patrícia, os protocolos formaram o seu livro de registro das aulas de música. Durante outra entrevista, desta vez com a aluna Isabela, os protocolos foram considerados como o primeiro “caderno de música”. Após Isabela explicar suas anotações, seus desenhos e o motivo pelo qual havia feito cada registro, a pesquisadora perguntou à aluna se ela desejava compartilhar algo mais, dando-lhe espaço para comentar a respeito de qualquer assunto relacionado à Oficina. Isabela, então, falou: “É a primeira vez que eu tenho um caderno de música” (Isabela - registro audiovisual).

Os protocolos adquiriram diferentes significados para as crianças, como o de "caderno de música”, o de "livro”, dentre outras nomeações dadas por elas. Percebeu-se que os alunos se engajaram no processo de confecção dos protocolos, escrevendo sobre os jogos vivenciados na Oficina, desenhando instrumentos usados em aula, registrando acerca dos novos amigos feitos, dentre muitos outros aspectos. Apenas o aluno Tiago pareceu pouco interessado nestes momentos de registro. Logo no segundo encontro da Oficina, ele comunicou que havia perdido seu caderno. Apesar disso, a pesquisadora entregou folhas em branco a ele para que, independente da perda de seu caderno, pudesse fazer suas anotações. No encontro seguinte, a pesquisadora deu um novo caderno a Tiago, porém, o aluno retornou na aula posterior avisando ter perdido este também. Embora parecesse não muito envolvido com os protocolos, Tiago fez registros em todas as aulas (ainda que com certa pressa) nas folhas entregues.

A professora Denise comentou acerca dos protocolos, afirmando que eles consistem em mais uma maneira de olharmos para as crianças. Citou também nomes de alguns alunos, relatando o engajamento observado neles com os registros. Falando a respeito do trabalho desenvolvido na Oficina de Música, ela adentra no assunto dos protocolos:

Eu gostei muito. Achei um trabalho muito cuidado, assim... passo por passo, a condução... Achei muito bom. Achei bem interessante. Até... até essa coisa do registro né. Eu acho que falta muito na minha prática. Como eu não to em escola há 
muitos anos... Quando a gente tá há muitos anos a gente já vai testando várias coisas, já vem com experiência né? E aí essa coisa do registro eu achei bem interessante, assim, mais uma maneira de olhar o aluno, né. (Denise - registro audiovisual).

Os protocolos revelaram questões importantes para análise, propiciando, assim como exposto por Denise, um olhar para as aprendizagens das crianças. Tendo em vista o grande número de registros (mais de cento e vinte páginas que foram produzidas pelas crianças no decorrer das aulas), apenas alguns constam neste trabalho. Os exemplos escolhidos (com desenhos e/ou textos) permitem perceber os vínculos estabelecidos pelas crianças, as novas amizades - decorrentes da participação na Oficina de Música, os sons e os instrumentos que relataram ter aprendido a tocar, a importância dada aos jogos criados por eles próprios, dentre tantos outros aspectos. Abaixo, alguns outros protocolos serão apresentados.

A figura 15 exibe protocolos relacionados ao jogo "Bate o monjolo". Os dois primeiros registros, das alunas Fernanda e Isabela, tratam dos instrumentos utilizados para o acompanhamento rítmico no jogo: os copos. O terceiro, da aluna Gabriela, registra a personagem "pirata” e o "tostão" - tesouro que é protegido pelos outros jogadores em cena. A quarta imagem, de autoria do aluno Pedro, ilustra o jogador tocando o instrumento/copo. A última imagem, com desenho feito por Bernardo, apresenta a personagem “pirata”. 


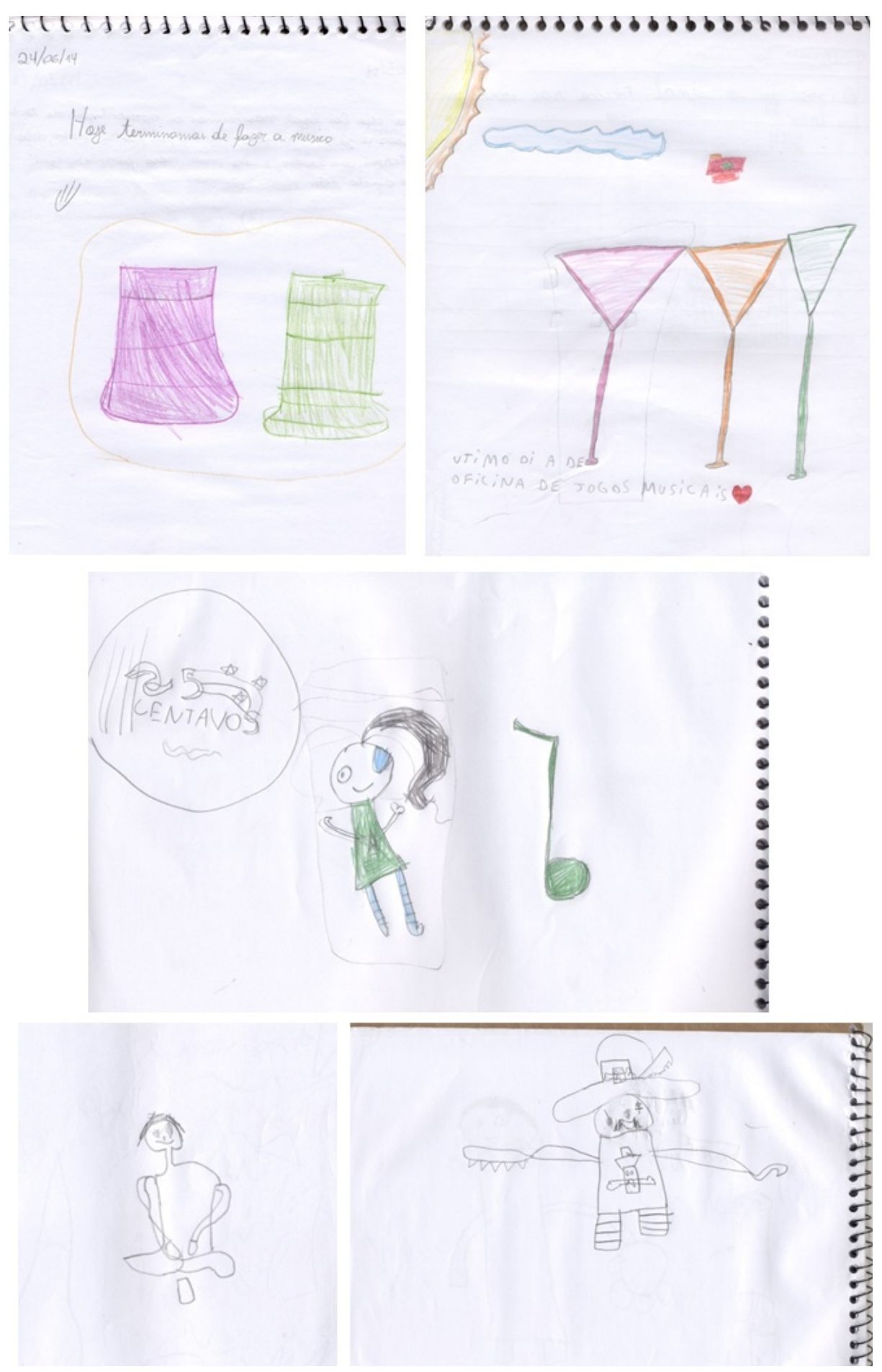

Figura 15 - Protocolos referentes ao jogo “Bate o Monjolo”.

Na figura abaixo, mostram-se protocolos referentes ao aprendizado de diversos sons durante a Oficina de Música, as interações e novas amizades estabelecidas no decorrer das aulas, além de uma das “capas” feitas para o “caderno de música”. Na primeira imagem, à esquerda, consta o protocolo de Luana, com registros realizados na capa de seu caderno. 
Abaixo desta imagem está o desenho de Isabela, que registra a aluna Luana em seu protocolo. Segundo Isabela, tal registro foi feito uma vez que Luana era sua nova amiga - amizade construída na Oficina de Música. No lado direito da figura constam outros três protocolos: acima, o registro de Pedro, referente aos sons do metalofone utilizado no jogo "Floresta e seus bichos”. Abaixo do protocolo de Pedro está o de Patrícia que, ainda na primeira aula, registrou suas ideias a respeito da música. Por fim, é apresentado o protocolo de Larissa, em que a aluna escreve sobre o jogo vivenciado em sala, além de inserir os nomes de diversos participantes da Oficina de Música dentro do desenho de um coração.
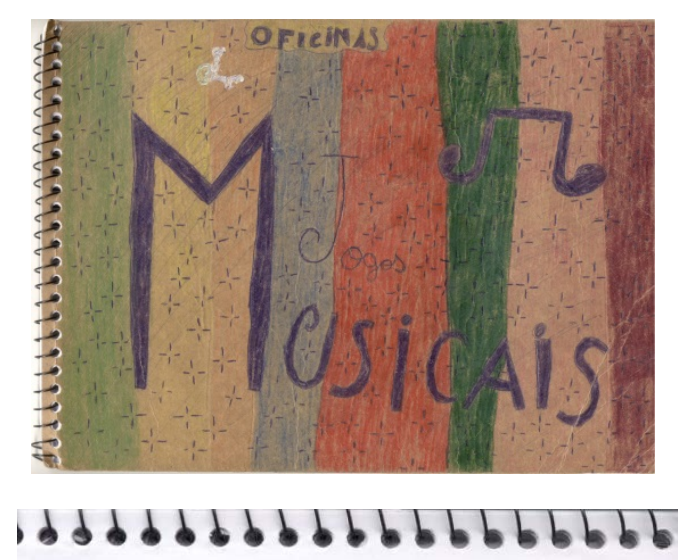
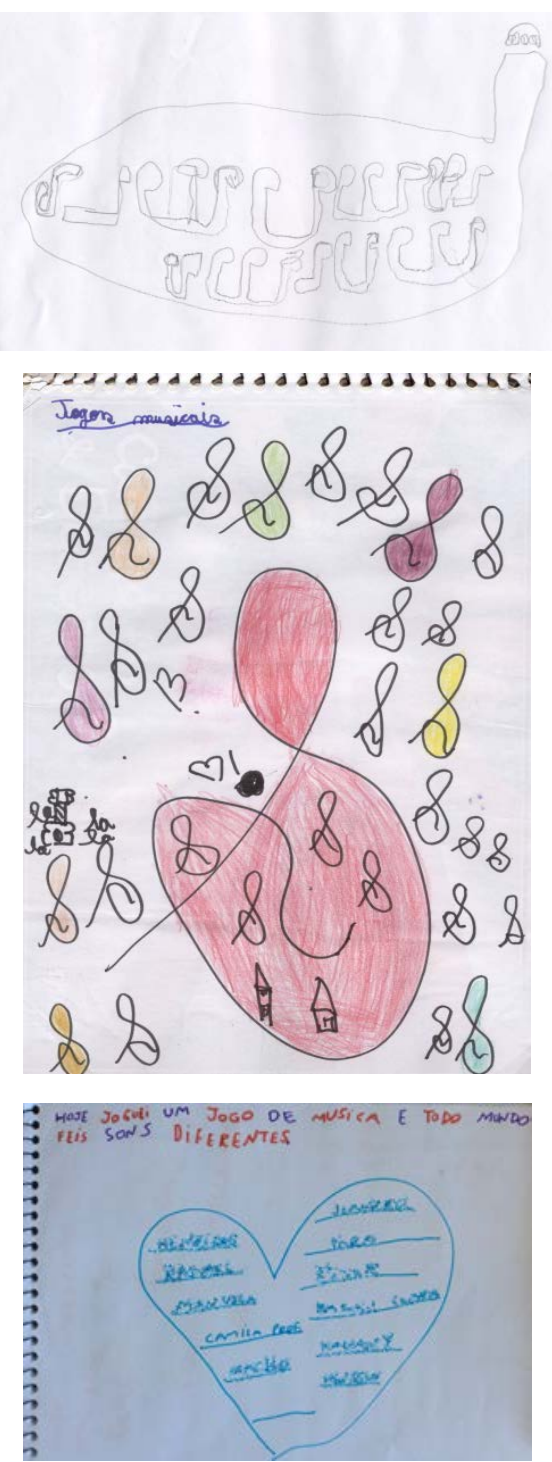

Figura 16 - Protocolos de Luana, Isabela, Pedro, Patrícia e Larissa. 


\subsection{O “PIANO” SUBSTITUINDO OS “TRENS”, O DIÁLOGO AO INVÉS DAS BRIGAS: DOIS CASOS ESPECÍFICOS PARA ANÁLISE}

Neste tópico serão destacados dois relatos compartilhados pela professora Denise no último encontro da Oficina de Música. Ambos os relatos acrescentaram a esta pesquisa informações muito importantes, possibilitando uma análise de especificidades em relação a dois alunos participantes da Oficina. Considerando a grande valia destas histórias e a necessidade de registro de tais exemplos, a professora Denise aceitou ser entrevistada - ainda que após o término das aulas. Logo, os relatos abaixo, sobre os alunos João e Rhauet, mesclam as informações cedidas pela professora no último encontro da Oficina de Música e no dia de realização da entrevista.

A primeira história compartilhada por Denise foi a respeito do aluno João. Esta criança foi diagnosticada com paralisia cerebral leve e, no primeiro dia de aula, foram informadas à pesquisadora algumas características comportamentais deste aluno. Dentre tais, explicou-se que este menino era bastante agressivo e que, constantemente, envolvia-se em alguns conflitos na escola.

Na Oficina de Música, João aparentava ser bastante inquieto, movimentando-se bastante pela sala (ainda que os outros alunos estivessem sentados participando de um jogo em roda, por exemplo). Apesar disso, diversas vezes João se entrosou com a turma, participou de jogos, dialogou e expôs suas opiniões em nossos debates. Um momento bastante significativo para o aluno (assim como para aqueles que presenciaram tal situação) foi quando ele pôde permanecer improvisando durante oito minutos no piano. Isto ocorreu no jogo “Floresta e seus bichos”, em que os jogadores poderiam improvisar, livremente, fazendo uso dos instrumentos disponibilizados em sala. Apesar de todos os outros alunos terem encerrado suas improvisações, João permaneceu “solando”. O grupo passou a demonstrar cansaço à medida que esperavam João encerrar seu solo. Entretanto, o aluno continuava bastante atento ao piano, em um jogo de escolha de sons...

Eu não sabia que ele tinha essa coisa né... Uma sensibilidade. Aquele dia do piano me impressionou, né? Quando ele começou a fazer [tocar]... uma coisa bonita, né? Delicada. Um menino que se mostra agressivo na maior parte do tempo. Ele viajou ali [no piano] (Denise - registro audiovisual). 
Tanto a professora Denise quanto o músico Allan, que estava presente em sala ajudando nas filmagens da Oficina, relataram ficar impressionados com a "sensibilidade" de João ao piano, afirmando que seu solo havia ficado muito "bonito".

Por saber do diagnóstico médico de João, esta experiência foi bastante marcante para os adultos que estavam participando ou observando a Oficina de Música. O aluno esteve motivado e envolvido durante os 8 minutos de improvisação, e seus colegas, ainda que cansados, aguardaram o fim da improvisação, em uma atitude de respeito ao João e àquele momento importante para ele ${ }^{39}$. Deste modo, reforça-se a ideia de uma educação musical como meio para desenvolver capacidades musicais e humanas (BRITO, 2011; KOELLREUTTER, 1997d), visando também ambientes de ensino e aprendizagem propícios à compreensão, respeito com o outro e amabilidade.

Há ainda outro fato muito significativo relatado pela professora a respeito de João. Ela contou que sempre que o aluno desenhava, ele registrava carros, ônibus, aviões, etc. Enfim, seus desenhos sempre consistiram em meios de transportes. Em outras disciplinas em que João participava, diversas vezes as professoras direcionavam atividades relacionadas a desenhos, pedindo que a turma registrasse o assunto abordado em sala. Porém, os desenhos de João, segundo a professora Denise, nunca estavam relacionados à temática da aula, independentemente do que fosse debatido em sala. A professora citou o exemplo das aulas de artes:

Nas aulas de arte... Sempre que pedia para desenhar alguma coisa... a gente tava falando, sei lá, sobre vitória régia: a lenda da vitória régia! Ele ia lá e desenhava um avião, desenhava um trem... ele sempre desenhava... Não importava o assunto, ele sempre desenhava isso (Denise - registro audiovisual).

Compreendendo o diagnóstico deste aluno e as suas "limitações”, não haveria problema caso seus protocolos da Oficina de Música registrassem aviões, carros, ônibus, motos... Entretanto, quando mostrei para a professora Denise os protocolos de João, ela ficou impressionada: ali estava registrado o piano no qual ele improvisou por 8 minutos, os animais

\footnotetext{
${ }^{39}$ Vale ressaltar que João parou de improvisar apenas quando a pesquisadora interrompeu a improvisação para comunicar o término da aula, pois o horário da escola precisava ser respeitado.
} 
(leão, gato) cujos sons foram imitados por ele em jogos de improvisação, instrumentos musicais usados em aula, dentre muitos outros desenhos.

A pesquisadora já havia atentado para os protocolos de João, pois chegou a pensar que ele não teria tanta paciência para sentar e fazer anotações a respeito da aula (considerando-se que ele não gostava de permanecer muito tempo "parado", fazendo registros, mas sim caminhando pela sala). Porém, também através deste relato, percebeu-se a forma com que o aluno interagiu com a Oficina, escrevendo e desenhando muito além de seus trens, ônibus e aviões...

Seguem, abaixo, alguns registros de João.

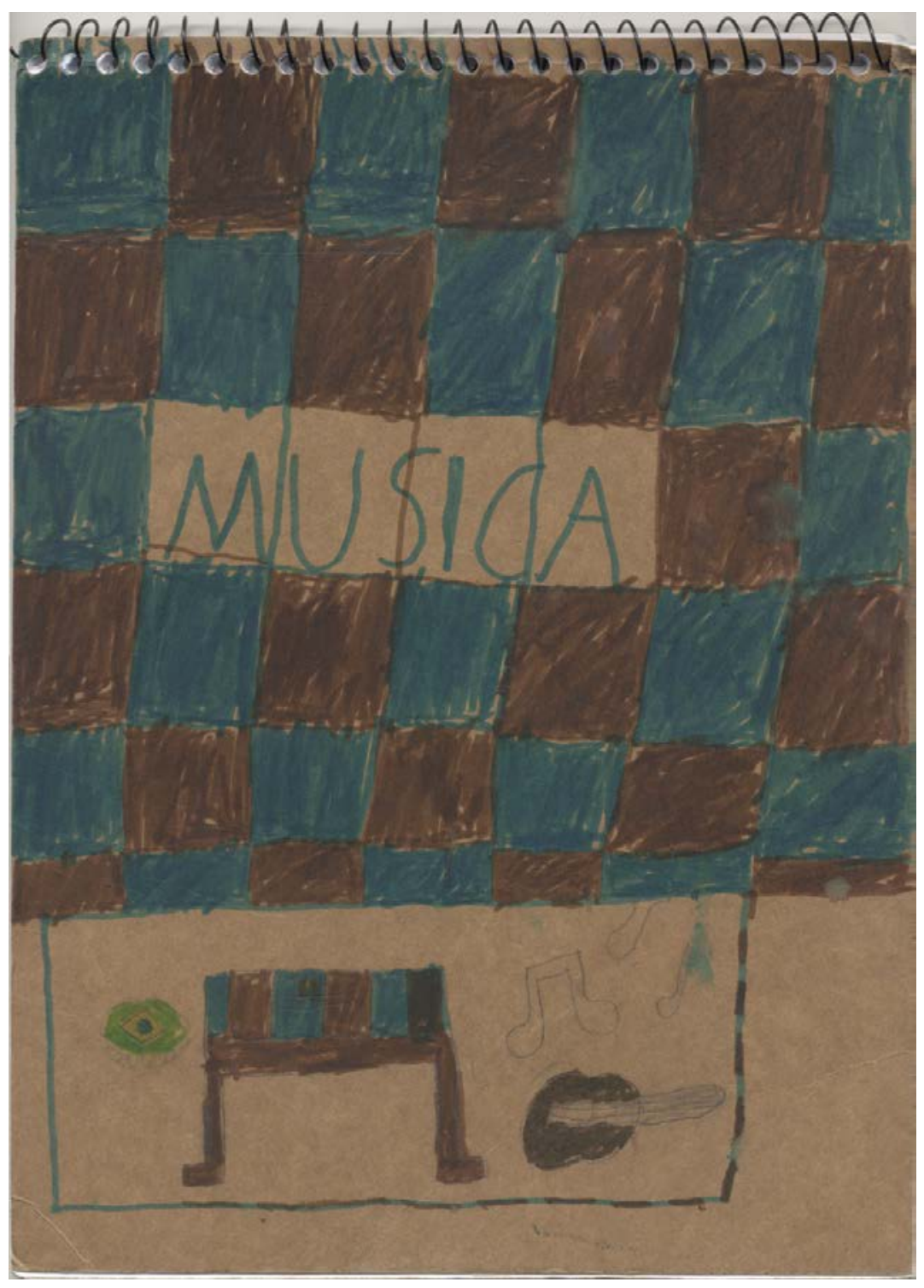

Figura 17 - Registros feitos por João na capa do caderno. 


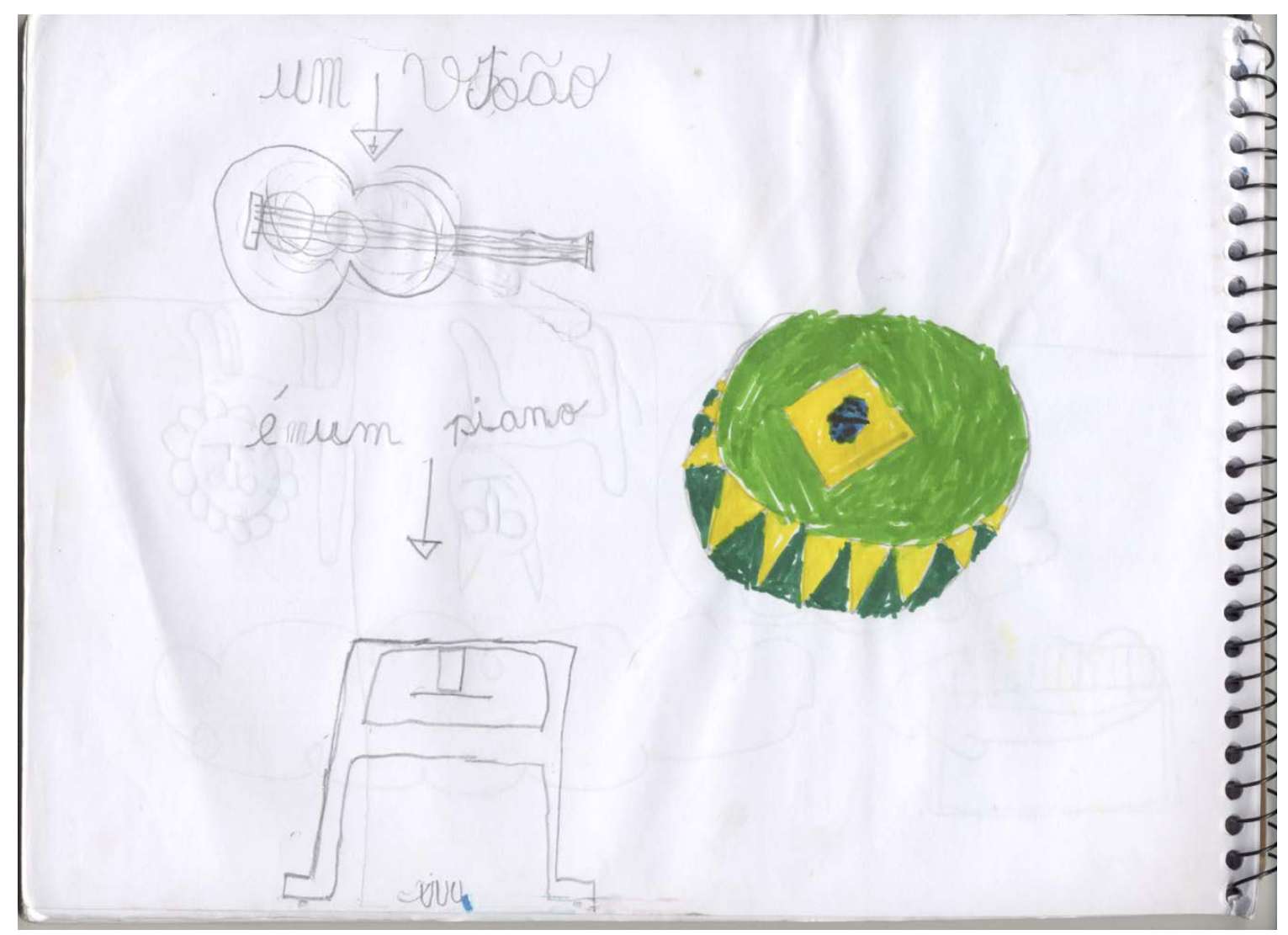

Figura 18 - Registro de alguns dos instrumentos disponibilizados em sala para os jogos.

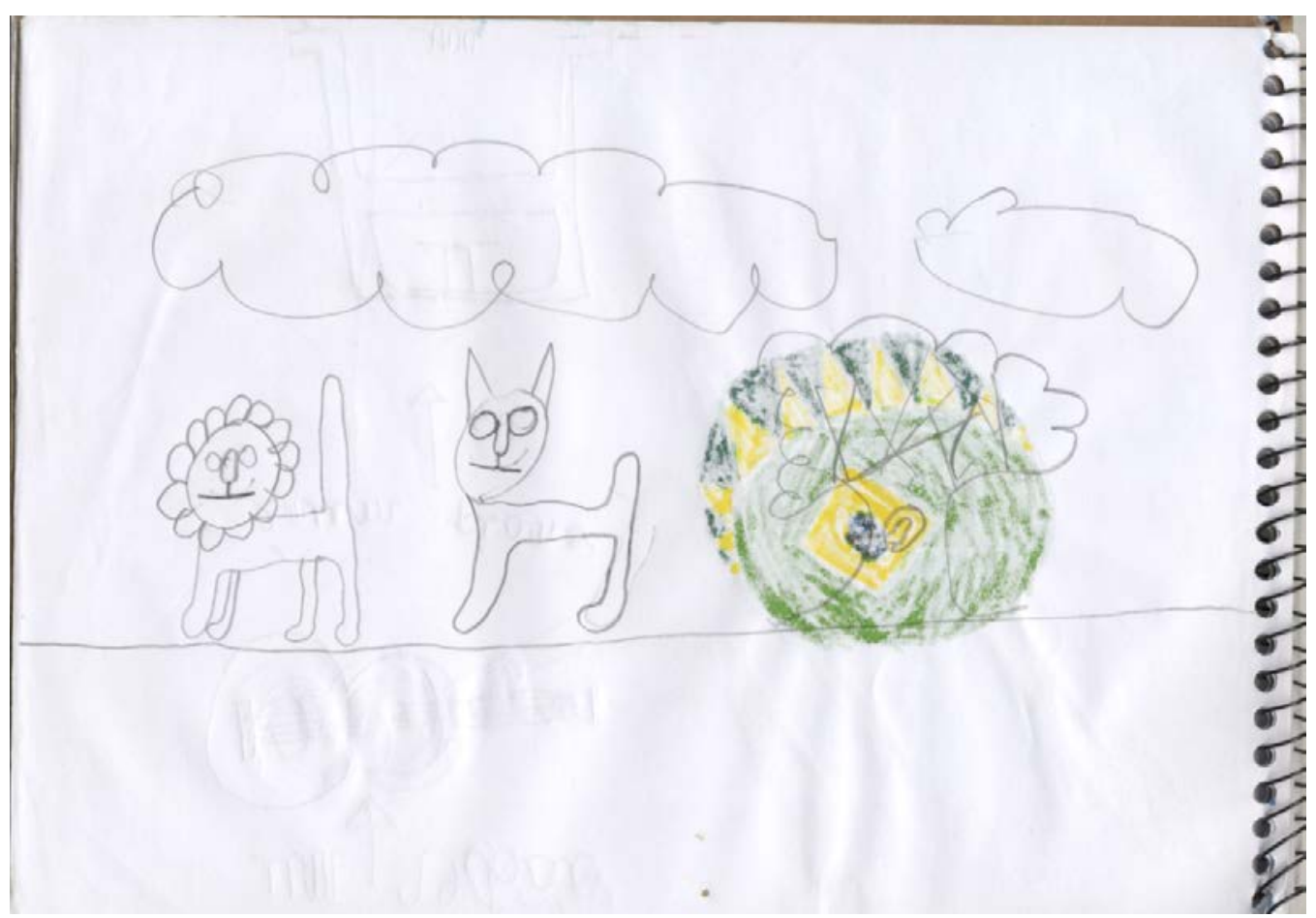

Figura 19 - Um leão e um gato: dois animais cujos sons foram imitados no jogo "Floresta e seus bichos". 


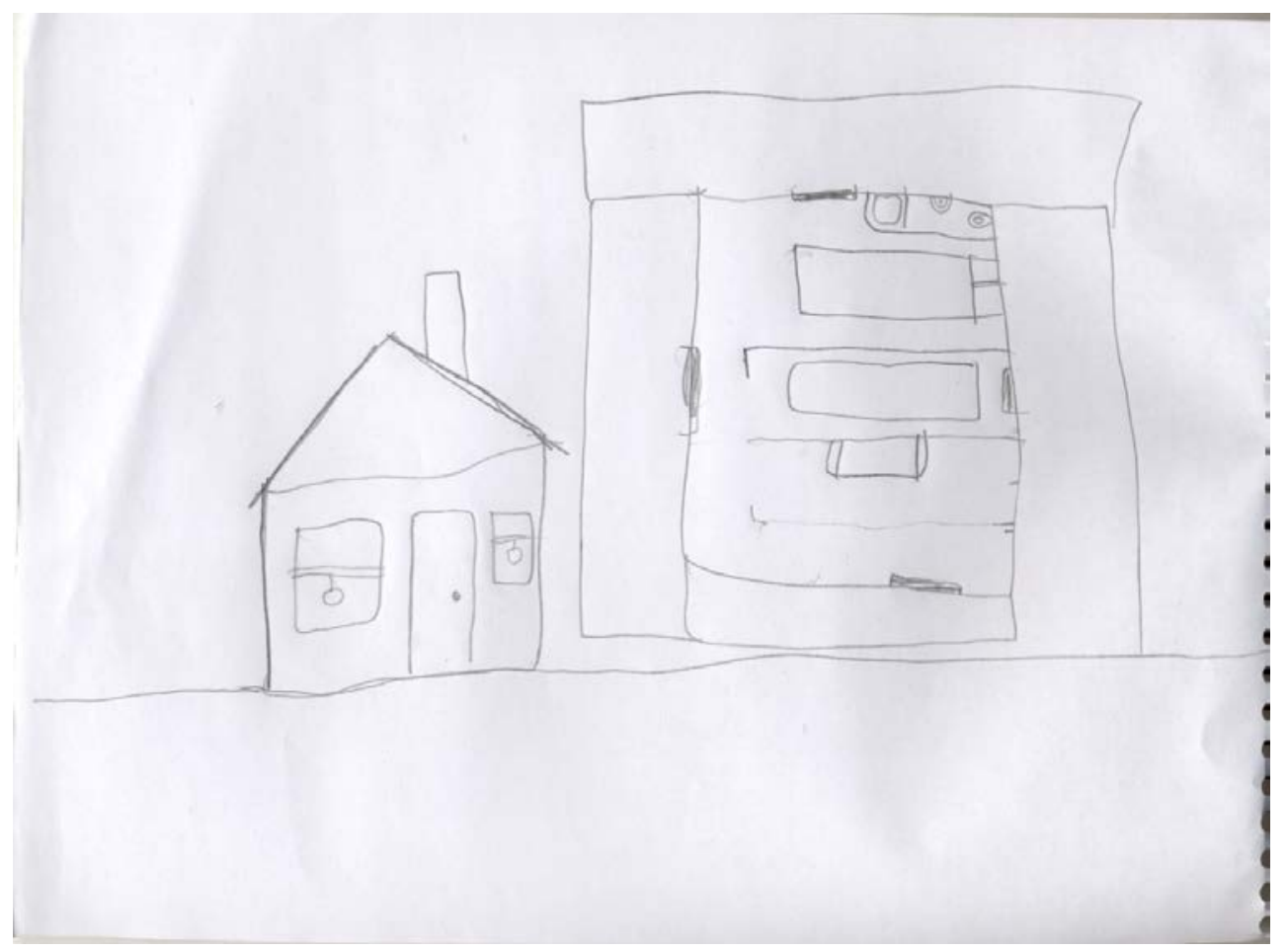

Figura 20 - Registro realizado após a apreciação do vídeo "Sound of Noise - Music for One Apartment and Six Drummers ${ }^{40}$,

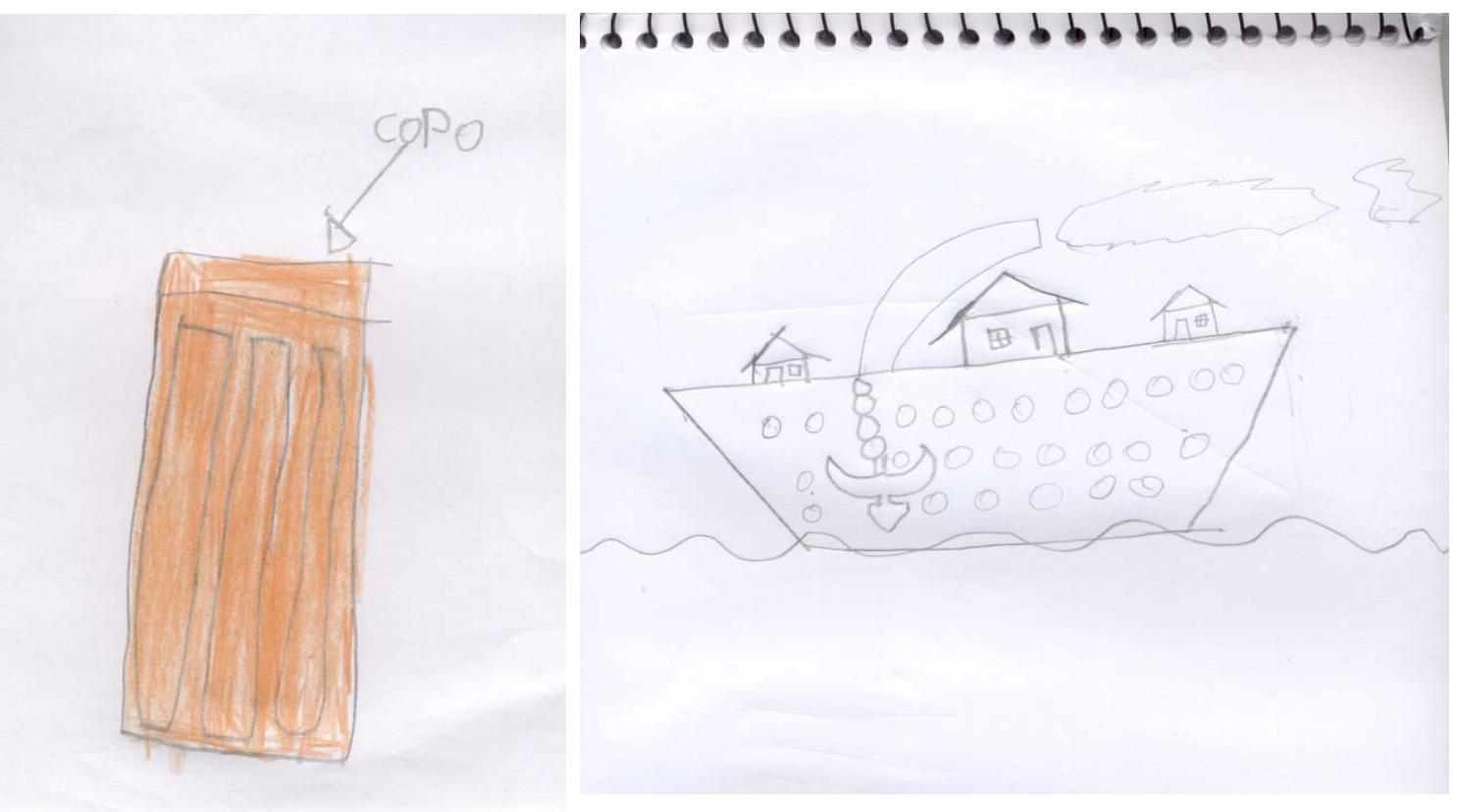

Figura 21 - Registros do jogo "Bate o monjolo". À esquerda, o copo utilizado como acompanhamento rítmico e durante as improvisações. À direita, o "barco do pirata”, personagem do jogo.

${ }^{40}$ Este vídeo pode ser visualizado no endereço: <https://www.youtube.com/watch?v=sVPVbc8LgP4>. 
Outra história bastante significativa e que traz respostas à questão de pesquisa deste trabalho, é a do aluno Marcos. Esta criança é bastante conhecida na escola por se envolver em brigas, discussões com os colegas de outras turmas, dentre outros aspectos relacionados à violência. No entanto, essa característica não aflorou durante todos os encontros da Oficina. Marcos, durante as aulas, divertia-se muito em todos os jogos, discorria bastante acerca das vivências apresentadas e sugeria, diversas vezes, outras maneiras de realizar as “brincadeiras”, modificando os jogos. Ele foi extremamente participativo no decorrer de todo o processo.

No último dia de aula, também durante a conversa com a professora Denise, ela comentou a diferença que percebeu no comportamento de Marcos na Oficina de Música e fora dela (em outros ambientes da instituição). Disse-me que o comportamento do aluno na Oficina era tão discrepante em relação a seus procedimentos em outras situações que havia, inclusive, relatado em reunião pedagógica acerca da mudança deste menino quando estava na Oficina.

\footnotetext{
Marcos... Menino muito agressivo. Com um complexo assim... de perseguição. Tudo é ele. Injustiçado. Tudo é contra ele, tudo é injustiça. Umas respostas que ele dava em aula... é que você não viu esse Marcos, né? [referindo-se ao "Marcos agressivo"]. Foram expulsos porque responderam o professor. Xingou o professor. É outro Marcos. Foi isso que me impressionou bastante. [...] Eu acho que ele tem um complexo de inferioridade muito grande acho que isso ajudou bastante. Nos jogos musicais ele era o $5^{\circ}$ ano né, o maior (Denise - registro audiovisual).
}

O depoimento da professora foi importante, pois ao atestar a diferença de comportamento do aluno na Oficina e em outras situações vividas na escola, atestava a importância da proposta para aquela criança. O contexto da Oficina de Música, marcado pelas vivências de jogos de improvisação cênico-musicais, pela interação entre crianças de diferentes idades e por processos de criação grupais, propiciou a Marcos um espaço diferente do que ele imaginava encontrar - como ele mesmo atestou durante uma das entrevistas. Reunindo suas falas, percebe-se que o aprendizado de "novos sons" em meio aos jogos de improvisação, o fato de poder “inventar músicas” em grupo e “usar a cabeça”, a aprendizagem do "som de leão” com o colega Leandro, a participação em uma aula que não era "chata”, mas era "de outro jeito" e a interação com o outro, podendo "ficar do lado dos amigos” e "conhecer outros amigos" foram aspectos que possibilitaram um espaço significativo a Marcos. Na Oficina de Música, sua relação com os outros não se estabeleceu 
com base em tapas ou brigas, mas com muitos diálogos, compartilhamento de ideias, respeito ao outro, trabalhos grupais, criação de músicas e jogos. Buscou-se instaurar um espaço de convivência que objetivava o desenvolvimento de capacidades musicais e humanas. E foi isto que se percebeu em Marcos: o fazer musical qualificando também características humanas, como defendido por Brito (2010).

Além disso, acredita-se que a participação em experiências lúdicas contribui para a "formação de um Eu saudável, considerando que o ser humano, como ser inacabado, vai se construindo, através de suas experiências individuais e interativas, ao longo da sua existência” (SANTANA, 2004, p. 33). Neste sentido, em convergência também com o pensamento de Pereira (2004),

\footnotetext{
Acredito que as atividades lúdicas possibilitam uma convivência mais humanizada, que nos ajuda a educar para a diversidade, para a compreensão do outro, assim como para o respeito com o outro, não nos remetendo apenas às questões externas, mas ao espaço interno de cada um, trabalhando as relações inter, intra e transpessoal (PEREIRA, 2004, p. 96).
}

Considerando a importância dos dois relatos apresentados, feitos por uma professora que acompanha João e Marcos em outros momentos (não apenas na Oficina de Música) e, portanto, conhece o comportamento destas crianças em outros ambientes, pensou-se na ampliação da coleta de dados. Sem saber destes fatos, por exemplo, a pesquisadora olharia para os desenhos de João e analisaria seus registros como desenhos possíveis de serem feitos por um menino do $3^{\circ}$ ano. Porém, ao saber o quanto estes registros são raros, tendo em vista que em outras ocasiões o aluno desenha apenas meios de transporte, estes protocolos tornamse extremamente significativos para a pesquisa em questão. Ter conhecimento da agressividade de Marcos em situações externas aos encontros da Oficina de Música e de sua amabilidade durante as aulas, além de saber que esta discrepância “impressionou” Denise, segundo suas próprias palavras, fazendo-a repassar estas informações em reunião pedagógica, permitiu uma compreensão, em maior dimensão, das contribuições dos jogos de improvisação vivenciados durante toda a prática da pesquisa-ação.

Estes dois casos (abordados de maneira mais específica), assim como os outros tratados no decorrer deste capítulo, assinalam a necessidade de discutirmos, atualmente, o papel da educação musical. A indústria cultural vem destacando a música como 
entretenimento e lazer, de maneira que se faz necessário resgatar discussões acerca do valor da música para a sociedade e de sua importância para o ser humano (FONTERRADA, 2008).

Encerro esta análise de dados destacando também o valor do jogo na educação. Para tal, finalizo este capítulo com as palavras de Pereira (2004), acreditando que as práticas lúdicas são recursos de desenvolvimento humano e que, na educação musical com crianças, “jogar com os sons” permite construir relações mais humanas.

Mais importante e prazeroso é perceber que podemos trabalhar com um campo de conhecimento que nos descortina possibilidades e renova as esperanças: a ludicidade. As atividades lúdicas, que propiciam que trabalhemos aspectos tão significativos para a humanidade e para o mundo de hoje, como o autoconhecimento, as relações interpessoais, a solidariedade, a autonomia e a autoexpressão, se mostram como um caminho viável, exequível, enfim, algo que não se encontra apenas em teorias mentais e livrescas, mas na realidade que já estamos construindo e vivenciando em nossas salas de aula. É claro que não podemos considerar as atividades lúdicas como uma panaceia capaz de curar todos os males da educação. Mas podemos considerá-las como um caminho possível para uma ação pedagógica transformadora (PEREIRA, 2004, p. 95). 


\section{CONSIDERAÇÕES FINAIS}

Nesta pesquisa buscou-se investigar as contribuições dos jogos de improvisação cênico-musicais no contexto de uma Oficina de Música. Tais contribuições foram expostas, no decorrer do processo, pelas próprias crianças participantes da Oficina, que indicavam suas opiniões acerca dos jogos vivenciados, das músicas criadas, dos processos de criação colaborativos e da proposta da Oficina como um todo. A partir da perspectiva das mesmas, a análise dos dados (apresentada no último capítulo desta dissertação) foi estruturada, tendo como ponto de partida os diálogos, os questionamentos e as reflexões que emergiram entre os alunos durante as aulas e entrevistas.

A abordagem qualitativa do trabalho, assim como a escolha por uma pesquisa-ação, permitiu que os procedimentos metodológicos fossem flexíveis, possibilitando mudanças no transcurso da ação. Deste modo, ao observar a importância da inserção de um novo procedimento - ainda que este não figurasse dentre as etapas previstas à prática da pesquisa pôde-se aplicá-lo. Isto se deve ao interesse da abordagem qualitativa pelo processo em si, que é dinâmico e imprevisível, movendo-se entre os eventos e a interpretação dos mesmos (SAMPIERI et al., 2013). Nesta concepção, uma entrevista semiestruturada, não prevista anteriormente às aulas na Oficina, foi realizada. Dirigida à professora de música Denise, participante da prática da pesquisa-ação, esta entrevista surgiu da necessidade de se ter um maior conhecimento a respeito dos alunos participantes da Oficina, visando informações acerca de seus comportamentos em outros espaços da Escola. A partir de uma coleta de dados que abrangeu também a perspectiva de Denise, acredito que este trabalho pôde ser enriquecido - principalmente ao considerar as narrativas feitas pela professora acerca dos alunos Marcos e João, assim como as comparações que ela estabeleceu a respeito do comportamento destes no contexto da Oficina e fora da mesma.

Esta proposta metodológica também possibilitou uma flexibilidade também em relação ao trabalho na sala de aula. Anteriormente à prática da pesquisa, os jogos que seriam desenvolvidos na Oficina não foram estabelecidos com exatidão. Embora tenha sido elaborada uma listagem prévia com a descrição de diversos jogos de improvisação possíveis de serem trabalhados com as crianças, ela não foi seguida com rigor: os jogos que nela foram descritos consistiam apenas em exemplos do quê poderia ser abordado em sala, sem que 
houvesse uma obrigação quanto à realização dos mesmos. Neste processo, alguns jogos pensados pela pesquisadora foram trabalhados, enquanto muitos outros nem chegaram a ser utilizados. Em sala, emergiam variações de jogos, pensadas pelos próprios alunos, assim como novos jogos criados pelas crianças. À medida que os participantes desejavam criar jogos ou propor modificações aos modelos trabalhados, um novo percurso era estabelecido. Buscou-se, portanto, a construção do caminho ao caminhar, em um processo de "aprender a apreender do aluno o que ensinar” (KOELLREUTTER apud BRITO, 2011, p. 33).

No decorrer dos encontros e das entrevistas, as crianças levantaram problemáticas acerca de diferentes questões, enriquecendo este trabalho com suas falas e reflexões. O modelo escolar como espaço de divisão por turmas/faixa etária foi bastante criticado pelas crianças, que ressaltavam a decorrente falta de interação entre os alunos. Deste modo, as considerações feitas pelos participantes da Oficina puderam ser relacionadas, durante a análise dos dados, com o pensamento de alguns autores abordados no primeiro capítulo desta dissertação, dentre eles Foucault (1999).

Aprender através dos jogos, segundo considerações feitas pelas crianças, proporcionou momentos em que, simultaneamente, divertiam-se e aprendiam. Nas entrevistas, elas debatiam a importância dos jogos de improvisação, valorizando-os por terem propiciado o aprendizado musical e o prazer do brincar. Suas falas em relação ao jogo como espaço de diversão, “curtição”, aprendizados, dentre outros pontos ressaltados, também encontraram suporte em referenciais teóricos adotados neste trabalho, tais como Brougère (1998), Lombardi (2005) e Pereira (2012).

As crianças também relataram o gosto por assumir papeis, por representar um detetive, um leão, um caçador, dentre tantas outras personagens que emergiam no decorrer dos jogos. Em seus protocolos, inclusive, há diversos registros das personagens representadas em cena, das funções/ações de cada personagem do jogo e, ainda, anotações em relação à função da plateia. Nos protocolos apresentados nas figuras 4, 5 e 12, por exemplo, a descrição que as crianças fazem do jogo é claramente relacionada à descrição das personagens que estarão em cena e de suas ações. Já no protocolo da figura 10, pode-se visualizar um registro acerca da plateia e da função que ela assumia no jogo. Em outro protocolo, apresentado na figura 13, é possível observar que a aluna refere-se ao jogo utilizando o nome de uma personagem, escrevendo: "Hoje fizemos a brincadeira do caçador" (fazendo menção ao jogo Floresta e seus bichos). Ao registrarem os jogos realizados em sala, alguns alunos desenharam um pirata, um 
leão ou um gato (figuras 15 e 19), relacionando a descrição do jogo, novamente, às personagens representadas em cena. Os elementos teatrais presentes nos jogos cativaram os alunos, que incorporaram os pontos de concentração "quem", "onde” e o "quê" (SPOLIN, 2008), por exemplo, também na criação de seus jogos.

Os jogos de improvisação foram eficazes ao propiciar momentos de liberdade, espontaneidade e desinibição - como já indicado nos trabalhos de Januzelli (2003), Japiassu, (2003), Martins, (2008), Pereira, (2012) e Spolin, (2007). A sensação de "outro tempo" aspecto característico do jogo segundo Huizinga (2012) - também foi observada, "sentida” tanto pelas crianças como pelos adultos que acompanharam a Oficina. O "aprender com o outro" foi ressaltado, indicando que relações interpessoais foram desenvolvidas no decorrer dos jogos. As crianças disseram ter feito novas amizades e ter conhecido pessoas com quem antes não conversavam devido à diferença de idade. Apontaram também que os jogos de improvisação, ao instaurarem um espaço de criação coletiva, propiciaram momentos de interação entre elas.

Os aprendizados musicais emergiram em meio à exploração sonora, pesquisas tímbristicas, ao manuseio de instrumentos (convencionais ou não), em processos que envolveram autonomia e liberdade para a improvisação, para a invenção de novas músicas, assim como para a criação de novos jogos. As falas das próprias crianças revelam seus aprendizados durante a Oficina de Música. Ao relatar o que aprenderam, os alunos destacaram: “O som de leão” e "sons diferentes” (Marcos), "Eu aprendi música de sons de árvore, de animais e de água” (Isabela), “Eu aprendi a tocar piano!” (João), “Inventar ritmos” (Bruno), “Inventar músicas” (Marcos), “Eu aprendi sobre todos os instrumentos” (Tiago), “Eu acho que a gente aprende a música, o que é a música” (Fernanda), “Aprendemos com os outros, outros sons!” (Bruno); “A gente aprende a ouvir, a tocar e a saber como a gente faz a música” (Fernanda), “Instrumentos que a gente não sabia que existia” (Gabriela), dentre outros...

Em relação ao aprendizado musical, podem ser destacadas também as novas percepções suscitadas nos alunos. Tiago, por exemplo, descobriu/compreendeu o corpo como um instrumento musical. Por não ter instrumentos em casa, o aluno havia decidido criar um e, posteriormente, mostrou à pesquisadora durante uma das entrevistas. Tiago prosseguiu batendo palmas, assobiando e explorando várias sonoridades que seu corpo propiciava, contando que aquele era o seu novo instrumento. 
O processo pedagógico-musical em meio aos jogos fez emergir reflexões também em relação aos modelos/concepções de aulas de música que circundam as ideias das crianças. Ao apresentar suas opiniões acerca das aulas de música da Oficina, os alunos traçaram comparações e expuseram outras concepções de aulas de música com as quais conviveram ou que esperavam encontrar na prática desta pesquisa. Suas falas abrangem críticas às aulas em que o ato de decorar notas é enfatizado (como é possível observar na fala de Fernanda ${ }^{41}$ ), assim como àquelas aulas em que o "som de cada um” é trabalhado/ensaiado à parte, ao invés de um trabalho de criação coletiva que propicia o "som de todos” (como relatou Marcos ${ }^{42}$ ).

Nesta perspectiva, assim como Brito (2012), acredito que a música na escola deve ser "viva":

\begin{abstract}
A música, dentro da escola, deve ser viva, efetivamente. "Música Viva” significa bem mais do que realizar exercícios mecânicos para desenvolver uma ou outra habilidade musical; mais do que aprender a cantar e/ou reproduzir músicas; preparar apresentações ou, ainda, iniciar-se nos processos de leitura e escrita musical. Tudo isso faz parte, sim, do todo de realizações musicais, que deve valorizar as atividades de criação, de exploração e pesquisa, bem como de reflexão. O pensamento musical se elabora e reelabora dinamicamente, e o verdadeiro sentido se estabelece quando a música é parte efetiva do jogo do viver, da vida em si mesma. BRITO, 2010, p. 93.
\end{abstract}

É válido, antes de concluir este trabalho, um olhar para questões singulares que emergiram no decorrer do processo, como aquelas a respeito dos alunos Marcos e João. O comportamento de Marcos na Oficina (bastante discrepante em relação à sua agressividade em outros ambientes), assim como o desenvolvimento observado no aluno João (tanto em sua relação com os outros como em seus desenhos), atestam que uma educação musical em modo menor, voltada ao jogo do criar, às singularidades, às ideias de música das crianças e ao favorecimento de exercícios do pensar, permite desenvolvimentos para além dos aspectos musicais. Uma educação musical que dá voz às crianças, valorizando a maneira lúdica como elas se relacionam com os sons, suas vontades de criar, de jogar e de inventar as próprias músicas (também em momentos de interação com o outro), é propícia ao desenvolvimento de capacidades musicais e humanas.

\footnotetext{
${ }^{41}$ Esta fala consta na página 115 deste trabalho.

42 Esta fala consta na página 114 deste trabalho.
} 
Enfim, ressalto a necessidade de uma educação musical que abarque muito mais do que aprendizagens musicais, acreditando na possibilidade de desenvolvimento do ser humano como um todo. Reafirmo a importância de um processo pedagógico-musical que considere a relação com o outro, o respeito, as dificuldades de cada aluno, a necessidade das interações, das criações conjuntas, dos trabalhos colaborativos, dentre tantas outras questões que deveriam consistir, a meu ver, objetivos de quaisquer trabalhos relacionados à educação. Portanto, compartilho da fala de Koellreutter (1998, p. 44), com a qual encerrarei este trabalho, acreditando que ela resume meu desejo e intenção ao propor esta pesquisa: “o humano, meus amigos, como objetivo da educação musical”. 


\section{REFERÊNCIAS}

ADRIANO, Carlos; VOROBOW, Bernardo. A revolução de Koellreutter. São Paulo, Folha Mais, 1999. Disponível em: <http://www1.folha.uol.com.br/fsp/mais/fs0711199905.htm >. Acesso em 10 mar. 2014.

AGAMBEN, Giorgio. Infância e história: destruição da experiência e origem da história. Tradução de Henrique Burigo. Belo Horizonte: Editora UFMG, 2005.

BARBOSA, Rita Cristiana. A disciplina e as táticas no universo escolar segundo Michel Foucault: a anatomia política do detalhe. Revista Espaço Acadêmico, ano VII, n. 74, s/p, 2007. Disponível em: <http://www.espacoacademico.com.br/074/74barbosa.htm>

BEINEKE, Viviane. Aprendizagem criativa e educação musical: trajetórias de pesquisa e perspectivas educacionais. Educação, Santa Maria, v. 37, n.1, p. 45-60, 2012.

BEINEKE, Viviane. FREITAS, Sérgio Paulo R. Lenga la lenga: jogos de mãos e copos. São Paulo: Ciranda Cultural, 2006.

BELEI et al. O uso de entrevista , observação e videogravação em pesquisa qualitativa. Cadernos de Educação (UFPel), v. 30, p. 187-199, 2008.

BELLODI, Júlio Novaes Ignácio; FONTERRADA, Marisa Trench de Oliveira. Criatividade e educação musical: uma proposta composicional numa escola de música da cidade de São Paulo. In: CONGRESSO NACIONAL DA ABEM, 15, 2006, João Pessoa. Anais... João Pessoa: Editora da UFPB, 2006. p. 264-268.

BITTENCOURT, Letticia. Foucault e a educação: libertação ou controle? Revista Sulamericana de Filosofia e Educação (RESAFE), n. 6/7, p. 25-35, maio/2006 - abril/2007.

BRESLER, Liora. Metodologias qualitativas de investigação em Educação Musical Revista CIPEM, n. 2, 2000.

BRITO, Teca Alencar de. Música na educação infantil: propostas para a formação integral da criança. São Paulo: Fundação Peirópolis, 2003. 
Por uma educação musical do Pensamento: novas estratégias de comunicação. 2007. Tese (Doutorado em Comunicação e Semiótica) - Pontifícia Universidade Católica de São Paulo, São Paulo, 2007.

2010.

Ferramentas com brinquedos: a caixa da música. Revista da ABEM, v. 24, p. 89-93,

Koellreutter educador: o humano como objetivo da educação musical. 2. ed. São Paulo: Fundação Peirópolis, 2011.

. Hans-Joachim Koellreutter: por quê? In: Gisele Jordão, Sergio Molina. (Org.). A Música na Escola. São Paulo: Editora Allucci \& Associados Comunicações, 2012.

BOGDAN, Robert; BIKLEN, Sari. Investigação qualitativa em Educação: fundamentos, métodos e técnicas. In: Investigação qualitativa em educação. Portugal: Porto Editora, 1994, p. 15-80.

BROUGÈRE, Gilles. Brinquedo e cultura. São Paulo: Cortez. 1995.

Jogo e educação. Porto Alegre: Artes Médicas, 1998.

Lúdico e educação: novas perspectivas. Tradução de Antonio Villar Marques de Sá.

Linhas Críticas, Brasília, v. 8, n. 14, jan./jun. 2002

Entrevista: Gilles Brougère. Revista Direcional Educador, n. 88, maio 2012. Disponível em: <http://www.direcionaleducador.com.br/edicao-88-mai/12/entrevista-gillesbrougere $>$.

BURNARD, Pamela. Understanding children's meaning-making as composers. In: DELIĖGE, Irene; WIGGINS, Geraint. Musical Creativity: multidisciplinary research in theory and practice. Psychology Press US, 2006. p.111 - 133.

CAMURRA, Luciana; BATISTELA, Cláudia Cristina. A entrevista como técnica de pesquisa qualitativa. Psicopedagogia On Line, 2009.

COELHO, Patrícia Margarida Farias. Um Mapeamento do Conceito de Jogo. GEMInIS, São Carlos, v. 2, p. 293-311, jan./jun. 2011. 
COLBERT, Vick. Entrevista. La educación prohibida. Documentário. Argentina: Creative Commons. 2012. Disponível em: <http://www.educacionprohibida.com>.

CORTELLA, Mário. Entrevista concedida à Silvia Colello. Disponível em:

$<$ http://www.congressosaber.com.br/index.php?acao=67\&codigo=431 >. Acesso em 20 set. 2014.

COSTA, Rogério Luiz Moraes. O músico enquanto meio e os territórios da livre improvisação. 2003. Tese (Doutorado em Comunicação e Semiótica) - Pontifícia Universidade Católica de São Paulo, São Paulo, 2003.

A livre improvisação e a filosofia de Gilles Deleuze. Per Musi (UFMG), Belo Horizonte, v. 26, p. 60-66, 2012.

DAMÁSIO, António R. O erro de Descartes. Emoção, razão e o cérebro humano. São Paulo: Companhia das Letras, 1996.

DELEUZE, Gilles. Lógica do Sentido. 4. ed. São Paulo: Perspectiva, 2006.

DELEUZE, G.; GUATTARI, F. Kafka - por uma literatura menor. Rio de Janeiro: Imago, 1977.

ENGEL, Guido Irineu. Pesquisa-ação. Educar em Revista, Curitiba, v. 16, p. 181191, $2000 . \quad$ Disponível em <http://www.educaremrevista.ufpr.br/arquivos_16/irineu_engel.pdf>.

ESCOLA DESEMBARGADOR AMORIM LIMA. Site da escola. Disponível em: <http://amorimlima.org.br/institucional/31-2/>. Acesso em: 23 out. 2014.

ESCOLA DE APLICAÇÃO - EAFEUSP. Site da escola. Disponível em: < http://www2.ea.fe.usp.br/escola-de-aplicacao >. Acesso em: 05 jun. 2014.

FLICK, Uwe. Desenho da pesquisa qualitativa. Porto Alegre: Artmed, 2009. 
FONTERRADA, Marisa Trench de Oliveira. De tramas e fios: um ensaio sobre música e educação. 2. ed. São Paulo: Editora Unesp, 2008.

FOUCAULT, Michel. Vigiar e Punir: nascimento da prisão. 20. ed. Petrópolis: Vozes, 1999.

FREIRE, Paulo. Pedagogia do oprimido. 14. ed. São Paulo: Paz e Terra, 1983.

Pedagogia da autonomia: saberes necessários à prática educativa. 25 ed. 1996. São Paulo: Paz e Terra, 1996.

Educação como prática de liberdade. 23 ed. São Paulo: Paz e Terra, 1999.

GALlO, Silvio. Pedagogia do Risco: experiências anarquistas em educação. Campinas: Papirus, 1995.

- Educação E Controle. Revista Sinpro Cultura - caderno de cultura do Sindicato dos Professores de Campinas e Região, $\mathrm{n}^{\circ}$ 23, caderno especial "Para Debater", $1995 . \quad$ Disponível em: <http://www.cedap.assis.unesp.br/cantolibertario/textos/0122.html>.

O que é Filosofia da Educação? Anotações a partir de Deleuze e Guattari. Perspectiva, Florianópolis, v. 18, n.34, p. 49-68, 2000. 79-97, 2004.

Repensar a educação: Foucault. Educação e Realidade, Porto Alegre, v. 29, n.1, p.

Pedagogia libertária: anarquistas, anarquismos e educação. São Paulo: Imaginário; Manaus: Editora da Universidade Federal do Amazonas, 2007.

Deleuze \& a Educação. 2. ed. Belo Horizonte: Autêntica, 2008.

Deleuze, Filosofia e Educação. Verbo 21. Entrevista. Disponível em: <http://www.petpsi.ufc.br/Documentos/Entrevista\%20com\%20S\%EDlvio\%20Gallo.rtf>. Acesso em 15 set. 2014. 
GERHARDT, Tatiana Engel; SILVEIRA, Denise Tolfo. Métodos de pesquisa. Porto Alegre: Editora da UFRGS, 2009.

GIDDENS, Anthony. Modernidade e Identidade. Rio de Janeiro: Zahar, 2002.

GODOY, Arilda Schmidt. Introdução à pesquisa qualitativa e suas possibilidades. RAE, v. 35, n. 2, p. 57-63, 1995.

GOLEMAN, Daniel. Inteligência emocional. Rio de Janeiro: Objetiva, sem data. Edição original: 1995.

GRIFFIN, Shelley. M. Listening to children's music perspectives: in-and-out-of-school thoughts. Research Studies in Music Education 31(2), 2009. p. 161-177.

HONORATO, Aurélia et al. A vídeo-gravação como registro, a devolutiva como procedimento: pensando sobre estratégias metodológicas na pesquisa com crianças. In: Reunião anual da ANPED, 29a , 2006, Caxambu. Anais... Caxambu: ANPED, 2006. p. 1-12.

HUIZINGA, Johan. Homo ludens: o jogo como elemento da cultura . São Paulo: Perspectiva, 2012.

JANUZELLI, Antonio. A aprendizagem do ator. 2. ed. São Paulo: Ática, 2003.

JAPIASSU, Ricardo. Jogos teatrais na escola pública. Revista da Faculdade de Educação. Universidade de São Paulo, São Paulo, v. 24, n.2, p. 81-97, 1998.

Ensino do teatro nas séries iniciais da educação básica: a formação de conceitos sociais no jogo teatral. 1999. Dissertação (Mestrado em Artes Cênicas) - Escola de Comunicação e Artes da USP, São Paulo, 1999.

Metodologia do ensino de teatro. 2. ed. Campinas, SP: Papirus, 2003.

KATER, Carlos. Música Viva. Brasília: Ministério das Relações Exteriores, 2004. Disponível em: <http://www.dc.mre.gov.br/imagens-e-textos/revista-textos-dobrasil/portugues/revista12-mat13.pdf>. Acesso em: 16 mar. 2014. 
KISHIMOTO, Tizuko Morchida. Jogo infantis: o jogo, a criança e a educação. Petrópolis:

Vozes, 1993.

. O jogo e a educação infantil. Perspectiva, Florianópolis, n. 22, p. 105-128, 1994.

Jogo, brinquedo e a educação. São Paulo: Cortez, 1996.

O brincar e suas teorias. São Paulo: Pioneira, 1998.

KOELLREUTTER, Hans-Joachim. Seminários Internacionais de Música. Educação Musical: Cadernos de estudo, $\mathrm{n}^{\circ}$ 6, Belo Horizonte: Atravez/EMUFMG/FEA/FAPEMIG, 1997a. p. 29-32.

O espírito criador e o ensino pré-figurativo. Educação Musical: Cadernos de estudo, nº 6, Belo Horizonte: Atravéz/EMUFMG/FEA/FAPEMIG, 1997b. p. 53-59.

Entrevista: Encontro com H. J. Koellreutter. Educação Musical: Cadernos de estudo, $n^{\circ}$ 6. Belo Horizonte: Atravez: EMUFMG/FEA/FAPEMIG, 1997c. p. 131-144.

O ensino da música num mundo modificado. Educação Musical: Cadernos de estudo, nº 6, Belo Horizonte: Atravéz/EMUFMG/FEA/FAPEMIG, 1997d. p. 37-42

Educação musical hoje e, quiçá, amanhã. In: LIMA, Sonia Albano de (org). Educadores Musicais de São Paulo: Encontro e Reflexões. São Paulo: Nacional, 1998. p. 39-45.

A revolução de Koellreutter. Entrevista concedida a Carlos Adriano e Bernardo Vorobow. Folha mais, $1999 . \quad$ Disponível em: <http://www1.folha.uol.com.br/fsp/mais/fs0711199905.htm>. Acesso em 12 mar. 2014.

KOUDELA, Ingrid Dormien. Jogos Teatrais. 7. ed. São Paulo: Perspectiva, 2009.

LATORRE, Maria Consiglia R. C. Sonoridades múltiplas: práticas criativas e interações poético-estéticas para uma educação sonoro-musical na contemporaneidade. 2014. Tese (Doutorado) - Universidade Federal do Ceará, Fortaleza, 2014. 
LIMA, José Milton de. $O$ jogo como recurso pedagógico no contexto educacional. São Paulo: Cultura Acadêmica, 2008.

LOIZOS, Peter. Vídeo, filme e fotografias como documentos de pesquisa. In: BAUER, Martin W.; GASKELL, George (org.). Pesquisa qualitativa com texto, imagem e som: um manual prático. Petrópolis: Vozes, 2002

LOMBARDI, Lúcia Maria Salgado dos Santos. Jogo, brincadeira e prática reflexiva na formação de professores. 2005. Dissertação (Mestrado) - Faculdade de Educação da USP, São Paulo, 2005.

LOIZOS, Peter. Vídeo, filme e fotografias como documentos de pesquisa. In: BAUER, Martin W.; GASKELL, George (Org.). Pesquisa qualitativa com texto, imagem e som: um manual prático. Petrópolis: Vozes, 2002.

LUCKESI, Cipriano. Ludicidade e atividades lúdicas: uma abordagem a partir da experiência interna, Coletânea Educação e Ludicidade, Ensaios 02, GEPEL, Programa de PósGraduação em Educação, FACED/UFBA, Salvador, v. 2, p. 22-60, 2002.

Educação, ludicidade e prevenção das neuroses futuras: uma proposta pedagógica a partir da biossíntese. Coletânea Educação e Ludicidade, Ensaios 01, GEPEL, Programa de Pós-Graduação em Educação, FACED/UFBA, Salvador, v 1, p. 09-42, 2000.

LUDWIG, Antonio Carlos Will. Fundamentos e prática de Metodologia Científica. Petrópolis, RJ: Vozes, 2009.

MANZINI, E. J. Entrevista semi-estruturada: análise de objetivos e de roteiros. In: SEMINÁRIO INTERNACIONAL SOBRE PESQUISA E ESTUDOS QUALITATIVOS, II, 2004, Bauru. Anais... Bauru: USC, 2004. p. 1-10

MARTINS, Janaína Träsel. Os princípios da ressonância vocal na ludicidade de jogos de corpo-voz para a formação do ator. 2008. Tese (Doutorado) - Universidade Federal da Bahia, Salvador, 2008.

MATURANA, Humberto. Emoções e linguagem na educação e na política. Belo Horizonte: Ed UFMG, 2001. 
NEVES, Libéria Rodrigues. O uso dos jogos teatrais na educação: uma prática pedagógica e uma prática subjetiva. 2006. Dissertação (Mestrado) - Faculdade de Educação da UFMG, Belo Horizonte, 2006.

OLIVEIRA, Almir Almeida de. Observação e entrevista em pesquisa qualitativa. Revista FACEVV, n. 4, p. 22-27, 2010.

OLIVEIRA, Cristiano Lessa. Um apanhado teórico-conceitual sobre a pesquisa qualitativa: tipos, técnicas e características. Travessias, 2009

PAREDES ORTIZ, Jesús. Aproximação teórica à realidade do jogo. In: MORENO MURCIA, Juan Antônio (Org.). Aprendizagem através do jogo. Tradução de Valério Campos. Porto Alegre: Artmed, 2005. p. 9-28.

PEARCE, Joseph Chilton. O fim da evolução. São Paulo: Cultrix, 2002.

PEREIRA, Eugenio Tadeu. Práticas lúdicas na formação vocal em teatro. 2012. 245p. Tese (Doutorado em Artes Cênicas) - Escola de Comunicação e Artes da USP, São Paulo, 2012.

PEREIRA, Lucia Helena Pena. Ludicidade em sala de aula: montando um quebra-cabeça com novos sabores e saberes. Coletânea Educação e Ludicidade, Ensaios 03, GEPEL, Programa de Pós-Graduação em Educação, FACED/UFBA, Salvador, v. 3, p. 81-97, 2004.

PUPO, Maria Lúcia de Souza Barros. Palavras em jogo: textos literários e teatro educação. 1997. Tese (livre- docência) - Escola de Comunicação e Artes da USP, 1997.

RAMOS, Mozart Neves. 'Brasil tem escola do século XIX', afirma especialista em educação. Bahia Repórter. Entrevista. 2012. Disponível em:

$<$ http://www.bahiareporter.com.br/ultimas_noticias.php?codnoticia=24970>.

REVERBEL, Olga. Jogos teatrais na escola. 2. ed. São Paulo: Scipione, 1993.

RYNGAERT, Jean-Pierre. O jogo dramático no meio escolar. Tradução de Christine Zurbach e Manuel Guerra. Coimbra: Centelha, 1981. 
Jogar, representar: práticas dramáticas e formação. Tradução Cássia Raquel da

Silveira. São Paulo: Cosac Naify, 2009.

SAMPIERI, Roberto Hernandez; COLLADO, Carlos Fernández; LUCIO, María del Pilar Baptista. Metodologia de Pesquisa. 5. ed. Porto Alegre, RS: Editora Penso, 2013.

SANTANA, Maria Bernadete Caldas. Abordagem integral da ludicidade, a partir da visão 'todos os quadrantes e todos os níveis' de Ken Wilber. Coletânea Educação e Ludicidade, Ensaios 03, GEPEL, Programa de Pós-Graduação em Educação, FACED/UFBA, Salvador, v. 3, p. 21-40, 2004.

SARMENTO, Manuel Jacinto. Imaginário e Culturas da Infância. 2003. Disponível em $<$ http://www.titosena.faed.udesc.br/Arquivos/Artigos_infancia/Cultura\%20na\%20Infancia.pd $\mathrm{f}>$. Acesso em 30/06/13 às 23h e 12min.

SCHAFER, Murray. O ouvido pensante. Tradução de Marisa Fonterrada. 2. ed. São Paulo: Ed. Unesp, 2011.

SCHOLLHAMMER, K. E. . As práticas de uma literatura menor. Ipotesi, Rio de Janeiro, v. 5, n.2, p. 59-70, 2002.

SILVA, Conrado. “Oficina de Música”. Revista Ar’te arte arte-educação, Festival de Campos do Jordão, n. 6, ano II, p. 12-15, 1983.

SPOLIN, Viola. Improvisação para o Teatro. Tradução de Ingrid Dormien Koudela e Eduardo José de Almeida. 5. ed. São Paulo: Perspectiva, 2008.

Jogos teatrais na sala de aula: um manual para o professor. Tradução de Ingrid Dormien Koudela. 2. ed. São Paulo: Perspectiva, 2012a.

Jogos teatrais: o fichário de Viola Spolin. Tradução de Ingrid Dormien Koudela. São Paulo: Perspectiva, 2012b.

STAKE, Robert E. Pesquisa Qualitativa: estudando como as coisas funcionam. Tradução Karla Reis. Porto Alegre: Penso, 2011. 
THIOLLENT, Michel. Metodologia da pesquisa-ação. 4. ed. São Paulo: Cortez, 1988.

ULPIANO, Cláudio. Estética Deleuziana. Texto que reproduz uma aula na Oficina Três Rios, em São Paulo, em 22/11/1993.

VÈLEZ, Carlos Alberto Jiménez. Entrevista. La educación prohibida. Documentário. Argentina: Creative Commons. 2012. Disponível em: <http://www.educacionprohibida.com>.

VISNADI, Gabriela Flor. A música que eu compus em grupo eu tirei do coração: perspectivas das crianças sobre a composição musical na escola básica. Dissertação (Mestrado em Música). Universidade do Estado de Santa Catarina, Florianópolis, 2013.

ZAGONEL, Bernadete. Em direção a um ensino contemporâneo de música. Ictus, Salvador, 1999. Disponível em: <http://www.bernadetezagonel.com.br/pacademicas/em-direcao.pdf>.

ZANETTA, Camila Costa. Jogos teatrais como colaboradores no processo pedagógico do canto. 2012. Trabalho de conclusão de curso (Graduação em Música). Universidade do Estado de Santa Catarina, Florianópolis, 2012.

Jogos cênico-musicais: uma abordagem da improvisação na Educação Musical para crianças. In: II JORNADA ACADÊMICA DISCENTE - PPGMUS ECA/USP, 2013, São Paulo. Anais... São Paulo: PPGMUS ECA/USP, 2013.

As influências de Hans-Joachim Koellreutter no cenário da música no Brasil: um breve panorama. In: II ENCONTRO IBERO-AMERICANO DE JOVENS MUSICÓLOGOS, 2014, Porto, Portugal. Actas... Porto: Tagus-Atlanticus Associação Cultural, 2014. p. 95-102.

ZANETTA, Camila Costa; BRITO, Teca Alencar de. Espaços para a Criação: a improvisação em jogos cênico-musicais. In: XXI CONGRESSO NACIONAL DA ABEM, 2013, Pirenópolis. Anais... João Pessoa: Editora da UFPB, 2013. p. 1020-1031.

Hans-Joachim Koellreutter em movimento: ideias de música e educação. In: XXIV CONGRESSO DA ASSOCIAÇÃO NACIONAL DE PESQUISA E PÓS-GRADUAÇÃO EM MÚSICA - ANPPOM, 2014, São Paulo. Anais..., 2014.

ZANETTA, Camila Costa; JACOBS, Daiane Dordete. Voz e cena: a prática pedagógica do canto através de jogos teatrais. In: XXI CONGRESSO NACIONAL DA ABEM, 2013, Pirenópolis. Anais... João Pessoa: Editora da UFPB, 2013. p. 2358-2369. 


\section{APÊNDICES}

APÊNDICE A - Roteiro de perguntas para as entrevistas semiestruturadas em grupos APÊNDICE B - Roteiro de perguntas para as entrevistas semiestruturadas individuais APÊNDICE C - Roteiro de perguntas para a entrevista semiestruturada com a professora Denise

APÊNDICE D - Autorização de uso de imagens 


\section{APÊNDICE A - Roteiro de perguntas para as entrevistas semiestruturadas em grupos}

- O que vocês acham dos jogos que tem sido feitos na Oficina?

- Vocês lembram de algum jogo? Qual?

- Qual foi o jogo que vocês mais gostaram? Por quê?

- O que vocês acham de aprender música com (por meio dos) jogos?

- O que pensam sobre as aulas de música serem assim - conduzidas por jogos?

- O que vocês acham que aprendemos quando estamos jogando? O que aprendemos de música durante o jogo? Aprendemos mais alguma coisa?

- O que vocês acham da participação da turma nesses jogos? (Como os colegas se comportaram, como participaram com seus sons, movimentos, criações, improvisações, etc.).

- O que vocês acharam de criar seus próprios jogos?

- Vocês gostaram de trabalhar em grupos? Por quê?

- E de ter um jogo feito por vocês? Por quê? 


\section{APÊNDICE B - Roteiro de perguntas para as entrevistas semiestruturadas individuais}

Observação: pode-se iniciar com perguntas sobre a Oficina já expostas acima, principalmente caso a criança a ser entrevistada não tenha comentado/falado muito durante a entrevista em grupo. Pode-se aproveitar este momento, em que ela estará sozinha com a pesquisadora, para colocar questões mais gerais sobre as quais ela não comentou anteriormente.

- Você fez anotações sobre os jogos vivenciados em seus cadernos?

- O que você anotou? Explique/conte sobre suas anotações.

(Observar as anotações de cada criança e, a partir desses registros, levantar outras questões. Ex.: O que você pensou quando fez este desenho?).

- O que você achou de ter um caderno para anotar o que quiser sobre a aula de música?

- Você gostou de poder fazer anotações na sala, em casa, em qualquer lugar (podendo levar o caderno para casa)? 


\section{APÊNDICE C - Roteiro de perguntas para a entrevista semiestruturada com a professora Denise}

- Há quanto tempo você atua como professora de música?

- Há quanto tempo você trabalha como professora de música na Escola de Aplicação da Faculdade de Educação da USP?

- Comente acerca da disciplina música na Escola de Aplicação. Relate quais são as turmas/anos que tem aulas de música, qual a carga horária desta disciplina, quantos professores da área de música atuam na escola, dentre outros fatores que considerar pertinentes.

- O que você pensa acerca da proposta da Escola de oferecer Oficinas às crianças?

- O que você teria a comentar a respeito da Oficina de Música realizada por meio desta pesquisa de mestrado?

- Você já conhecia os alunos participantes da Oficina de Música? Caso sim, explique como os conheceu (lecionando em turmas das quais eles faziam parte, em projetos, em outras oficinas, etc.) e cite o nome destes.

- Como você avalia, em geral, a participação/envolvimento dos alunos na Oficina de Música?

- Você comentou no último encontro da Oficina de Música especificidades em relação aos alunos Marcelo e Rhauet. Você poderia contar estas histórias novamente para fins de registro? - E dentre os outros alunos que você conhecia: há algum comentário em relação à participação destes na Oficina de Música? Algo lhe chamou a atenção (seja na relação de um aluno com a música, frente ao ato de jogar, ante as propostas de criação/improvisação ou ainda nas relações que estabeleceram - ou não - com o outro, com o grupo e consigo mesmo)?

- Gostaria de comentar algo mais? Há alguma questão que não foi levantada nesta entrevista e que você ache importante apontar? 


\section{APÊNDICE D - Autorização de uso de imagens}

\section{Prezados pais ou responsáveis}

A Oficina Jogos Musicais faz parte do projeto de pesquisa da mestranda Camila Costa Zanetta, com orientação da profa. Dra. Maria Teresa Alencar de Brito. Tendo em vista a finalidade do projeto, faz-se necessário o registro em áudio e vídeo do trabalho, visando produção de conhecimentos na área da educação musical.

Considerando os objetivos acadêmicos e científicos da Oficina, a participação dos(as) alunos(as) é condicionada à autorização de uso de imagens, gravações em áudio e vídeo, além de depoimentos resultantes do trabalho. Isto inclui a cessão de direitos de uso de imagens das crianças, sem nenhum direito a remuneração. Salientamos que os nomes dos(as) alunos(as) não serão divulgados, sendo substituídos por nomes fictícios, mas a identificação das crianças será possível através das imagens.

Autorizo o aluno(a) a participar da Oficina Jogos Musicais, atividade decorrente do projeto de mestrado de Camila Costa Zanetta, que será documentada através de entrevistas, protocolos (registros feitos pelas crianças na forma de desenhos, colagens, escritos, entre outros suportes), filmagens e gravações. Autorizo também a utilização dos dados coletados nas aulas para fins de publicação e apresentação em eventos acadêmico-científicos, na dissertação de mestrado e em outros trabalhos que possam resultar da formação acadêmica da mestranda.

Nome do pai ou responsável:

RG:

Assinatura (de acordo):

São Paulo, de de 2014. 